Shakespeare and Hospitality

Ethics, Politics, and Exchange

Edited by

David B. Goldstein

and Julia Reinhard Lupton 


\section{Shakespeare and Hospitality}

This volume focuses on hospitality as a theoretically and historically crucial phenomenon in Shakespeare's work with ramifications for contemporary thought and practice. Drawing a multifaceted picture of Shakespeare's numerous scenes of hospitality-with their depictions of greeting, feeding, entertaining, and sheltering - the collection demonstrates how hospitality provides a compelling frame for the core ethical, political, theological, and ecological questions of Shakespeare's time and our own. By reading Shakespeare's plays in conjunction with contemporary theory as well as early modern texts and objects-including almanacs, recipe books, husbandry manuals, and religious tracts-this book reimagines Shakespeare's playworld as one charged with the risks of hosting (rape and seduction, war and betrayal, enchantment and disenchantment) and the limits of generosity (how much can or should one give the guest, with what attitude or comportment, and under what circumstances?). This substantial volume maps the terrain of Shakespearean hospitality in its rich complexity, offering key historical, rhetorical, and phenomenological approaches to this diverse subject.

David B. Goldstein is Associate Professor of English at York University, Canada.

Julia Reinhard Lupton is Professor of English and Comparative Literature at the University of California, Irvine. 


\section{Routledge Studies in Shakespeare}

1 Shakespeare and Philosophy Stanley Stewart

2 Re-playing Shakespeare in Asia Edited by Poonam Trivedi and Minami Ryuta

3 Crossing Gender in Shakespeare Feminist Psychoanalysis and the Difference Within James W. Stone

4 Shakespeare, Trauma and Contemporary Performance Catherine Silverstone

5 Shakespeare, the Bible, and the Form of the Book Contested Scriptures Travis DeCook and Alan Galey

6 Radical Shakespeare

Politics and Stagecraft in the Early Career Christopher Fitter

7 Retheorizing Shakespeare through Presentist Readings James O'Rourke

8 Memory in Shakespeare's Histories

Stages of Forgetting in Early

Modern England Jonathan Baldo

9 Reading Shakespeare through Philosophy Peter Kishore Saval
10 Embodied Cognition and Shakespeare's Theatre The Early Modern Body-Mind Edited by Laurie Johnson, John Sutton, and Evelyn Tribble

11 Mary Wroth and Shakespeare Edited by Paul Salzman and Marion Wynne-Davies

12 Disability, Health, and Happiness in the Shakespearean Body Edited by Sujata Iyengar

13 Skepticism and Belonging in Shakespeare's Comedy Derek Gottlieb

14 Shakespeare, Romeo and Juliet, and Civic Life The Boundaries of Civic Space Edited by Silvia Bigliazzi and Lisanna Calvi

15 Shakespeare in Hate Emotions, Passions, Selfhood Peter Kishore Saval

16 Shakespeare and Hospitality Ethics, Politics, and Exchange Edited by David B. Goldstein and Julia Reinhard Lupton 


\title{
Shakespeare and Hospitality
}

Ethics, Politics, and Exchange

\author{
Edited by \\ David B. Goldstein and \\ Julia Reinhard Lupton
}


First published 2016

by Routledge

711 Third Avenue, New York, NY 10017

and by Routledge

2 Park Square, Milton Park, Abingdon, Oxon OX14 4RN

Routledge is an imprint of the Taylor \& Francis Group, an informa business

(C) 2016 Taylor \& Francis

The right of the editors to be identified as the authors of the editorial material, and of the authors for their individual chapters, has been asserted in accordance with sections 77 and 78 of the Copyright, Designs and Patents Act 1988.

All rights reserved. No part of this book may be reprinted or reproduced or utilised in any form or by any electronic, mechanical, or other means, now known or hereafter invented, including photocopying and recording, or in any information storage or retrieval system, without permission in writing from the publishers.

Trademark notice: Product or corporate names may be trademarks or registered trademarks, and are used only for identification and explanation without intent to infringe.

\section{Library of Congress Cataloging-in-Publication Data}

Names: Goldstein, David B., 1972- editor. I Lupton, Julia Reinhard, 1963- editor.

Title: Shakespeare and hospitality: ethics, politics, and exchange / edited by David B. Goldstein and Julia Reinhard Lupton.

Description: First edition. I First edition. I New York: Routledge, 2016. I

Series: Routledge studies in Shakespeare; 16 | Includes bibliographical references and index.

Identifiers: LCCN 2016002122

Subjects: LCSH: Shakespeare, William, 1564-1616-Knowledge-

Manners and customs. I Shakespeare, William, 1564-1616-Criticism

and interpretation. I Hospitality in literature. I Manners and customs in literature. I Hospitality-History.

Classification: LCC PR3069.M3 S53 2016 | DDC 822.3/3-dc23

LC record available at http://lccn.loc.gov/2016002122

ISBN: 978-1-138-79716-1 (hbk)

ISBN: 978-1-315-75734-6 (ebk)

Typeset in Sabon

by codeMantra 


\section{Contents}

Introduction 1

DAVID B. GOLDSTEIN AND JULIA REINHARD LUPTON

PART I

Oikos and Polis

1 “Will You Walk in, My Lord?”: Shakespeare's Troilus and Cressida and the Anxiety of Oikos ANDREW HISCOCK

2 A Digression to Hospitality: Thrift and Christmastime in Shakespeare and in the Literature of Husbandry JESSICA ROSENBERG

3 “Here's Strange Alteration!”: Hospitality, Sovereignty, and Political Discord in Coriolanus

THOMAS P. ANDERSON

PART II

Economy and Ecology

4 Hospitality's Risk, Grace's Bargain: Uncertain Economies in The Winter's Tale JAMES KEARNEY

5 Hospitality in Anthony and Cleopatra SEAN LAWRENCE

PART III

Script

6 Ave Desdemona 
vi Contents

7 As You Like It and the Theater of Hospitality JAMES KUZNER

8 Hospitable Times with Shakespeare: A Reading of King Lear THOMAS J. MORETTI

\section{PART IV}

Scripture

9 "Her Father Loved Me, Oft Invited Me":

Staging Shakespeare's Hidden Hospitality in The Travels

of the Three English Brothers

SHEIBA KIAN KAUFMAN

10 Hospitality in Twelfth Night: Playing at (the Limits of) Home JOAN PONG LINTON

11 Thinking Hospitably with Timon of Athens:

Toward an Ethics of Stewardship

MICHAEL NOSCHKA

Contributors

Index 


\section{Introduction}

\section{David B. Goldstein and Julia Reinhard Lupton}

In act 1 , scene 4 of Macbeth, Duncan, having declared Malcolm his successor, announces that he will be traveling to Inverness as Macbeth's guest. Macbeth responds by electing himself the king's "harbinger":

The rest is labour, which is not used for you; I'll be myself the harbinger, and make joyful The hearing of my wife with your approach. So humbly take my leave. $(1.4 .45-47)^{1}$

Although by the end of the play, the word "harbinger" bears our modern sense of an omen or forerunner (5.6.10), its appearance here is more technical: the harbinger was the court official who preceded the monarch on his or her progresses in order to ensure, among other things, that "the bedrooms had chairs, beds, carpets, and hangings" - tasks gathered under the rubric of "appareling," the same term used when great halls and banqueting houses were set up as theaters using timber frames and handsome textiles to assemble stages and seating. ${ }^{2}$ Duncan has just spoken of "investing" Malcolm as heir (1.4.41), one of many references to formal attiring in the play. What is at stake in the harbinger's charge is another kind of investiture, not of persons but of spaces, which will be decked with special fabrics whose affordances of enclosure and warmth also symbolize magnificence and support the tremulous sense of occasion required by the hosting of a king. ${ }^{3}$ Duncan will presumably meet his end in a properly outfitted state bed, a confection of elaborate tapestries hung on a wood frame that erected a chamber within the chamber, a holy of holies for royal guests. ${ }^{4}$ Duncan is killed as a guest in his sleep, a violation of the simultaneously social and somatic forms of trust that the rituals, architecture, and accoutrements of hospitality are designed to cultivate.

In a similar complex of hospitality rituals and theatrical actions, the staging of the banquet scene (what kind of table? how is it brought on stage? how is it angled? what seating will furnish it?) often shapes a range of other dramaturgical choices in response to the affordances of the theatrical setting. On one hand, banqueting tables carried in by servant-stagehands and set on trestles aptly link the great halls of Renaissance England to the fast scene 
changes required of theatrical work; such tables, moreover, with their clear heads, sides, and lower reaches, also support the hierarchy of formal dining that is with us still. A round table or even simply an open circle of stools (as Trevor Nunn imagined it at The Other Place in 1976), on the other hand, activates a thrust stage or theater in the round and conscripts the audience as guests at the party, occupying their own outer ring. ${ }^{5}$ However and wherever it is staged, the scene draws on hospitality's play between hierarchy and equality, both among hosts and guests and between chairs of state and mere stools, and it builds the hospitable scripts of invitation, greeting, toasting, and leave-taking into its dramatic action. ${ }^{6}$ The scene incorporates liturgical and Eucharistic resonances-hosting as Hosting-into its ritual texture while maintaining those references on the profane plane of exposure to the forms of creaturely life that hospitality tends to: our need for shelter and sleep and food and drink as well as recognition and acknowledgement, and the various ecologies of building types, durable goods, consumable offerings, and social scripts that communities have composed to shape the delivery of those benefits.

Macbeth, like many of Shakespeare's plays, is as fascinated by the failure of hospitality as by its invocation. Against a set of ideals about the obligation to shelter, feed, and honor the guest within one's literal and proverbial walls-ideals that early modern England both held sacred and fiercely debated-Macbeth depicts hospitality in the form of its own undoing. It "repeatedly evokes the rites and pleasures of conventional hospitality," writes James Heffernan, "even as it undermines them." 7 The play forms and dissolves around scenes and spaces of welcome: the castle that is also a trap, entered through a door whose gatekeeper-the porter-provides comic welcome for the audience even as he tries to keep out devils and Jesuits. The play's intense focus upon eating and banqueting culminates in the witches' cauldron, a meal that is poisonously open to anyone- "Open locks, whoever knocks" (4.1.61). If in King Lear, the door is constantly being shut in someone's (Cordelia's, Kent's, Edmund's, Lear's, Gloucester's) face, in Macbeth it is constantly flung wide open to unsuspecting guests or (in the case of Lady Macduff) hosts. The dangerous permeability of Macbeth's spaces of welcome gives spatial form to hospitality's most frightening trait-the absolute vulnerability of guests and hosts to each other. The leap of faith hospitality demands, noble as it may be, is under constant pressure in the Shakespearean playworld. Hospitality is the space of negotiation between subjects. It is the warmth and peril of acknowledging other people.

This collection explores the range of connections between hospitality and theater in the plays of Shakespeare. The staging of acts of hospitality, we argue, bids readers and audiences to attend to Shakespearean drama in manifold ways. As culturally expressive forms of life, hospitality rituals disclose a historically contingent, time-bound and place-rich world of ritual and routine. Insofar as acts of hospitality require self-disclosure before an assembly of others, their staging solicits a theatrical space in which symbolic 
welcome and political and commercial transaction coincide and collide. And finally, insofar as greeting guests engages foundational questions concerning the claims of the stranger, hospitality belongs to philosophical inquiries into the ethics of obligation and reciprocity. Taking up the historical, theatri$\mathrm{cal}$, and philosophical dimensions of meeting and greeting in Shakespeare, these essays explore hospitality as vernacular phenomenology: as a daily engagement, at once cognitive and embodied, into the conditions of human co-existence in a world of dearth and plenty as well as risk and trust. In the process, we aim to test hospitality as a compelling framework for inquiring into the core ethical, political, theological, and ecological questions of Shakespeare's time and our own. Who is my neighbor? What is a gift? Whom should I feed? What is for dinner, where will I sleep, and when can I leave? These intimate questions, their answers derived from highly coded social customs composed out of mixed media in response to the available affordances of particular environments, are at once practical, existential, and theatrical. It is the constitutive braiding and mutual implication of those vectors that renders hospitality as a rich terrain for literary and philosophical exploration and theatrical inventiveness.

The later Tudor and Stuart period was marked by a sense of what observers decried as the "decay of hospitality and good housekeeping," brought about by both the pressures of the Reformation and the rise of early capitalism. ${ }^{8}$ (See essays in this volume by Andrew Hiscock, Jessica Rosenberg, and Michael Noschka.) Hospitality drew on the medieval, chivalric, and Catholic past while also absorbing Renaissance motifs from the Continent and looking forward to aspects of liberal modernity, including discourses of tolerance and pluralism as well as mass "entertainment." In Shakespeare's England, a decrease in celebrations in the patriarchal old style elicited fears of declining charity for the poor, diminishing care for servants, and a general weakening of neighborly generosity-the kind of crisis that besets As You Like It, a play that begins with Oliver and Duke Frederick's renunciations of hospitality, and initiates the process of recuperation with Duke Senior's offering of hospitality to Orlando and Adam, as explored by James Kuzner in this volume. If As You Like It reveals itself as a play intimately engaged with questions of service, sustenance, accommodation, and their interlinked environments, so too does nearly every other play in the Shakespearean canon, from The Comedy of Errors with its closing doors and beckoning meals, to King Lear's poor hovel on the heath, to Pericles with its seaside and ship-bound scenes of welcoming and care. In each play, the historical pressures and mixed ingredients of fast-changing and unevenly developing repertoires of reception and hosting are assembled, dramatized, resolved, and charged anew.

If hospitality in Shakespeare's England has a history, it also evokes a philosophical tradition that crosses periods and places. Biblical and classical writings on the rights of guests, early Protestant discourses on hosting and gifting, Immanuel Kant's essay on "Perpetual Peace," and Emile Benveniste's 
philological scansion of hospitality's internal divisions and reversals (hostis as host, guest, and enemy) continue to inspire ethical, juridical, and phenomenological responses to the problem of the stranger. ${ }^{10}$ (On this complex of conversations, see essays in this volume by James Kearney and Sean Lawrence.) As taken up by contemporary philosophers and critical theorists, hospitality engages both the most intimate acts of domestic experience and the broadest platforms of law, diplomacy, theology, and ethics. ${ }^{11}$ Hospitality builds its spaces of refuge, succor, and entertainment out of a mix of real materials (foods, décor, serving implements, lighting techniques) and aspirational desires (for salvation, happiness, love, recognition, or respite from need). Housing their own incipient theorization in response to the occasion and resources at hand, such spaces are at once date-stamped by history and animated by perennial questions around the status of the stranger and the place of human beings in larger economies of debt and benefit.

Theater itself constitutes a hospitality event, the convening of a company around an act of entertainment that incubates and amplifies the theatricality incipient in all human exchange. Hospitality and theater share a set of actions, including invitation, approach, entry, welcoming, reception, and exit-routines that allow persons and things to appear and resonate in shared spaces that contribute actively to both cognition and action. (See essays by David Hillman and Thomas J. Moretti on hospitality as theater.) If all men and women "have their exits and their entrances," as Jaques famously says in As You Like It, then these comings and goings dramatize spaces of hospitality, roleplaying, and disappearance-including the requisite, if tragic, hospitality of death. As a form of home theater, hospitality events craft scenes for appearing, whether we are witnessing the tremulous encounter among persons unknown to each other, or apprehending objects and environments as supporting actors in the drama of reception. Moreover, theater as an institution was closely bound up with the entertainment needs of the court while also contributing to an increasingly commercial hospitality industry. It is no accident that scenes of hospitality and its violation abound in dramatic literature, since the theater recapitulates the host-guest relation in its economic transactions and spatial environments.

By reading Shakespeare's plays in conjunction with contemporary theory as well as early modern texts and objects-including almanacs, recipe books, husbandry manuals, religious tracts, and other items designed to support hospitality-this collection reimagines Shakespeare's playworld as one charged with the risks of hosting (rape and seduction, war and betrayal, enchantment and disenchantment) and the limits of generosity (how much can or should one give the guest, with what attitude or comportment, and under what circumstances?). This volume addresses the unique ways in which hospitality toggles between history and its sublations. We aim to map the terrain of Shakespearean hospitality in its rich complexity, demonstrating the importance of historicist, rhetorical, and phenomenological approaches to this multifaceted subject. 
Characterizing the methodological richness of hospitality as an entry into Renaissance theater, the genres addressed in the volume include comedy (Twelfth Night, The Merchant of Venice, As You Like It), tragedy (Hamlet, Othello, Troilus and Cressida, Coriolanus, King Lear, Timon of Athens, Antony and Cleopatra), and romance (The Winter's Tale, and Day, Wilkins, and Rowley's The Travels of the Three English Brothers). Historical facets of hospitality addressed in these pages include the discourse of thrift, the politics of embassy, and the conventions of greeting before and after the Reformation. Theoretical issues include the tension between host and guest; the status of otherness; hospitality's contribution to concepts of charity, service, duty, friendship, and love; hospitality as theology and phenomenology; and the roles of gender, economics, and ecological interconnection in hospitality events. Taken as an ensemble, these essays configure hospitality as a set of responses and routines that draw hybrid galaxies of objects and ideas into affiliations and antagonisms both historically contingent and existentially persistent. Hospitality-as theme and ritual, idea, and act-summons us to work between historical and theoretical paradigms, accessing new archives while forging direct links between the past and its futures. Historicism provides key way-finding mechanisms for navigating hospitality's bio-political-theological terrain, but we must also turn to other resources, including cognitive and phenomenological models, to benefit from hospitality's full range of performances.

The collection is organized into four sections that reflect the zones of action and reflection in which hospitality unfolds. Part I, "Oikos and Polis," tracks hospitality's management of the threshold between private and public spaces. Overflowing the borders of the household, hospitality concerns politics insofar as laboring, gendered, and foreign guests come to share with sovereign hosts the eat-work-play spaces convened by acts of entertainment. Such spaces, often formed under highly regulated, punitive, or conscripted conditions, become themselves the topic of evaluation, acknowledgment, or reform within the framework of hospitality, which can also provide occasions for normally silent persons to speak or act in public.

Part II, "Economy and Ecology," considers hospitality's organization of economic and environmental affordances in and around the oikos, whose efforts are dedicated to the labor of tending to creaturely life. Hospitality as a form of gifting concerns reciprocity, exchange, and their limits and failures among human actors. Hospitality's rituals of sustenance also regulate interspecies dependencies within seasonal, regional, and climactic flows with their own distinctive tempos, durations, and fragilities.

Part III, "Script," examines the theatrical rhythms native to hospitality and the manner in which the plays tap those rhythms for dramatic ends. Theater asks us to respond to an intrinsically open invitation, a form constituted by its constant flux of adaptations and reimaginings as well as comings and goings. All scripts are hospitable scripts, Shakespeare's most of all, as seen by the longevity and global reception of his texts in a range of performance styles and traditions. 
Finally, Part IV, "Scripture," focuses on the instances of community and discourses of virtue convoked by hospitality in its theological dimensions. In Jewish, Christian, and pagan routines of welcome, hospitality events disclose a repertoire of mythic scenarios (the disguised guest, the messianic banquet, the murderous host) that recur in various guises throughout the historical and geographical record, and that feed both the practical and the philosophical dimensions of the theater of hospitality.

\section{Part I: Oikos and Polis}

Regulating the relationship among strangers in prepolitical regimes such as those depicted in Homer's Odyssey and the Hebrew Scriptures, hospitality cultivates the threshold between the oikos or household and the polis or city, bidding a provisional politics to pitch its tent upon scenes of sojourning, supplication, and bodily care. The first set of essays examines the status of the oikos as a scene of immanent politics. Andrew Hiscock establishes the Greek origins of Renaissance hospitality in a reading of Troilus and Cressida; Jessica Rosenberg traces the resonances of husbandry and housekeeping in Hamlet; and Thomas P. Anderson looks at the politics of friendship in Coriolanus. Using a range of sources and approaches that include sixteenth-century household tracts, classical philosophy, and contemporary theory, this trio of essays establishes the domestic grounds and political stakes of hospitality in Shakespearean drama and the worlds on which it drew.

In “'Will You Walk in, My Lord?': Shakespeare's Troilus and Cressida and the Anxiety of Oikos," Andrew Hiscock turns our attention to the Greek oikos as a source of Western hospitality paradigms, drawing upon writings of antiquity (with their specific cultural concerns about gendered spaces and religious commitments in their understandings of hospitality and household) as well as early modern cultural debates surrounding the necessary actions and obligations of the host. His essay considers the ways in which militarism, community-building, and the erotics of chivalry enable Shakespeare to diversify the conceptualization of home and hospitality in Troilus and Cressida. Paying particular attention to the trafficking of land, goods, and bodies, his discussion analyzes the ways in which fugitive images of the family and household become basic building blocks in the construction of cultural mythologies of belonging among both Greeks and Trojans. These in turn are played off against compelling concerns onstage through violent displacement, violated hospitality, and the pleasure principles associated with opportunism and appropriation.

In "A Digression to Hospitality: Thrift and Christmastime in Shakespeare and in the Literature of Husbandry," Jessica Rosenberg places Renaissance husbandry and housekeeping discourses at the center of theatrical considerations of hospitality by taking up Hamlet's retort to Horatio as a key to the home economics of hosting: "Thrift, thrift, Horatio, the funeral baked meats / Did coldly furnish forth the marriage tables" (1.2.178-180). With these 
lines, Hamlet charges his mother with both good housekeeping and bad hospitality: she has observed the everyday imperatives of thrift but broken the ritual calculus of mourning. Though critics have suggested that the play distances itself from the mundane principles of household wisdom (most often ventriloquized by Polonius), Rosenberg proposes that Hamlet's conflicted moral economy in fact repeats and extends a tension already central to the printed advice literature of husbandry and household management. Reading texts by Fitzherbert and Tusser, Rosenberg argues that hospitality holds an often-embattled position in husbandry manuals of the sixteenth century, pitting a neighborly impulse to spend against the basic imperative to save. In Tusser's popular book of household rules, what Derrida calls the antinomy between the law of unlimited hospitality and the multiple and conditional laws of its application are echoed in the arrangement of the text itself. Returning to Shakespeare's vivid image of leftover flesh, Rosenberg rereads Gertrude's thrift and Hamlet's superfluous mourning in light of the temporal politics of household economy. She reveals the play's engagement with the aporia of hospitality already theorized in early modern practices of everyday life.

In “'Here's Strange Alteration!': Hospitality, Sovereignty, and Political Discord in Coriolanus," Thomas P. Anderson reads Levinas and Derrida in order to analyze and evaluate the politics and theology of hospitality. His essay forges a relationship between hospitality, as that which requires no invitation and is subject to no laws or limitations, and friendship in Shakespeare's Coriolanus. He argues that the play offers an affirmative politics imagined in the portrayal of the intimate encounter between Aufidius and Coriolanus in act 4 . The scene of absolute hospitality between the two warriors destabilizes friendship as a political force at the same time that it allows us to glimpse its liberating potential. More precisely, Coriolanus's new relationship with Aufidius reconceptualizes the logic of hospitality common in the early modern period, suggesting that the play disrupts the communitarian space imagined in the classical rhetoric of friendship. In reconfiguring classical notions of friendship common during the early modern period, Shakespeare makes the case that sovereign absolutism is, in fact, nourished by hospitality characterized by consensus and fraternity. Coriolanus, by contrast, represents a concept of hospitality fraught with division and violence. Drawing on recent accounts of the influence of an early modern politics of conflict, this chapter makes the case that the play's representation of a dissensual politics of hospitality redistributes the force of sovereign absolutism by disrupting community in favor of division, disagreement, or, according to the play, “perpetual spoil” (2.2.119). Anderson's focus on the constitutive condition of friendship's failure as a sustainable force that shapes political sovereignty in Coriolanus suggests that the play's commitment to a dissensual politics generates an agonism that precludes rapprochement and establishes a form of contested friendship, or absolute hospitality, as a counter to political absolutism. 


\section{Part II: Economy and Ecology}

As Andrew Hiscock demonstrates in his essay, oikos is the root of economy. Hospitality as the art of the oikos touches on a range of economic, proto-economic, and aneconomic issues that stem from the reciprocity of the gift and the dream of a gift without exchange. Oikos is also the root of ecology, pointing to hospitality's management of and interaction with mixed populations of plants, animals, humans, and things that coexist in complex terrains and climates. Essays by James Kearney and Sean Lawrence track the ethical challenges posed by exchange in The Winter's Tale and Antony and Cleopatra.

In "Hospitality's Risk, Grace's Bargain: Uncertain Economies in The Winter's Tale," James Kearney draws on a long history of thought on hospitality and obligation from Seneca to Luther to Derrida in an effort to grapple with the ways that hospitality crosses discursive registers-ethical, economic, and theological. Economic logic haunts the ethical in The Winter's Tale, shaping notions of love and service, friendship and fidelity, and devotion and grief. A crucial feature of this staging of a pervasive economic logic is the evocation of an idealized hospitality threatened by overwhelming obligation. The Winter's Tale begins and ends with scenes of hospitality that are concerned with the possibility of expenditure without exchange. But if this is a play in which an idealized hospitality promises to escape economies of debt and obligation, it is also a play in which hospitality is always threatened by the possibility of the poisoned cup. Kearney's contention is that Shakespeare's desire to think with and through hospitality in The Winter's Tale stems, in part, from hospitality's peculiar position between idealized and agonistic relations, between the disavowal of the economic and the acknowledgment of the economic as an inescapable horizon.

In "Hospitality in Anthony and Cleopatra," Sean Lawrence contrasts the approaches of Emmanuel Levinas and Marcel Mauss in order to address the politics and theology of a play saturated with unsatisfying acts of hosting. Shakespeare's play alternates between two different worlds, Rome and Egypt, which both express their values by consumption and elaborate acts of hospitality. The triumvirs demonstrate their brief solidarity with Pompey by common inebriation in an all-male, all-night party aboard his ship. The canons of hospitality overrule even Pompey's ambition when he refuses to kill his guests, although doing so would leave him, as Menas the pirate promises, "lord of the whole world." For their parts, the Egyptians feast with competitive enthusiasm; even Cleopatra's death is surrounded by imagery of breast-feeding and is associated with figs. Yet all the relationships built on hospitality seem basically unstable. The alliance between the triumvirs and Pompey, or even between the triumvirs themselves, barely outlasts their hangovers. Anthony explodes in rage at Cleopatra's suspected perfidy at least three times, despite all their partying together. Lawrence argues that not only do the characters of Shakespeare's play fail to create stable relationships through hospitality, but in fact they must fail. While a relationship 
can be built on exchange, it can never overcome the suspicion of being merely tactical, self-serving, or temporary. Whereas Levinasian hospitality may not realize itself in a clear political expression, instead collapsing into competitive exchanges that constitute the Maussian gift, its radical perspective nevertheless allows a judgment of hospitable practice both in Mauss and in Shakespeare's play.

\section{Part III: Script}

Composed of entries and exits, greetings and valedictions, anticipations, main events, and dénouements, hospitality is always incipiently theatrical, and relies on inherited routines and images for its deployment. The set of essays in Part III address the performative dimensions of hospitality. David Hillman analyzes greetings in Othello; James Kuzner tracks hospitality as the ability to entertain the scripts of others in As You Like It; and Thomas J. Moretti attends to the temporal dimensions of Lear as an event that must be endured.

In "Ave Desdemona," David Hillman focuses on hospitality as a script that shapes the routines of coming and going. Greetings and leave-takings are key moments in every hospitality event, moments that encapsulate the paradoxes of hospitality as a whole-its ambivalence and equivocations, its heartfelt generosities and subtle power plays, its profound tensions between amity and enmity, servility and mutuality, spontaneity and calculation, and improvisation and rule. Salutations also manifest hospitality as dramaturgy (both theater and hospitality are structured around exits, entrances, and the forms of gesture and speech that they afford). Hillman's essay examines a single, curious instance of greeting in Shakespeare-Cassio's elaborate flourish upon the arrival of Desdemona in Cyprus ("Hail to thee, lady! and the grace of heaven"). This salutation invokes the Ave Maria-a paradigmatic instance in Western culture of the greeting of the other as constitutive of their subjectivity. Cassio's Ave, in evoking the idea of Mary as mediatrix, alerts us to a crucial feature of Othello: the role of intercession in the downfall of all the play's protagonists. Hillman argues that it is through turning away from the directness of engagement potentially manifested in the moment of greeting that the play moves from comedy toward tragedy.

In "As You Like It and the Theater of Hospitality," James Kuzner pays close attention to the way in which the play's distinctly theatricalizing scenes of hospitality involve not so much individual inventiveness (as manifested in Rosalind's self-authoring feats) as a willingness to welcome the pretensions and expectations of others. Being hospitable, Kuzner argues, means helping another person craft a scene in which to appear. The ultimate gift is to entertain and acknowledge the fantasies that others hold about themselves, an ethical and political gesture that Kuzner sees at work in scenes involving the person of Orlando as he responds to Adam, Duke Senior, and Rosalind. As You Like It, Kuzner suggests, asks us to explore how to be hospitable when we 
don't mean it, "when the best we can do is play along," and he suggests the relevance of this ethic to our practice of quotidian hospitality today.

In "Hospitable Times with Shakespeare: A Reading of King Lear," Thomas J. Moretti shifts our focus to the act of theater as itself an hospitable event subject to the tensions of timing. Moretti argues that one of Shakespeare's key theatrical projects was and is to make the theater inhospitable enough to accommodate insight, depth, and awareness. Theater companies could be hospitable so long as they helped audiences to pass the time. And yet, certain of Shakespeare's plays are often inhospitable precisely because they force audience members to dwell on excruciating moments of violence, loss, and grief. Moretti reads Jacques Derrida's On Hospitality alongside Henri Bergson's phenomenology of time to emphasize that timely affect is at stake during moments of hospitality in and outside the theater. He demonstrates how King Lear's hastenings and delays directly signal to us what Shakespeare would have readers, auditors, and actors endure.

\section{Part IV: Scripture}

Hospitality is a theological as well as an economic and political category. These final essays examine the role of Scriptural motifs in shaping the scripts of Shakespearean dramas of hospitality. Sheiba Kian Kaufman effects an interweaving of Kantian cosmopolitanism and a scriptural account of hospitality to explore the nature of Elizabethan pluralism. Joan Pong Linton traces the Susanna story in the messianic moods of Twelfth Night, and Michael Noschka uses Biblical stewardship to evaluate hospitality and service in Timon of Athens.

In “'Her Father Loved Me, Oft Invited Me': Staging Shakespeare's Hidden Hospitality in The Travels of the Three English Brothers," Sheiba Kian Kaufman addresses the cosmopolitan dimensions of hospitality that precede and follow from Kant, drawing on theologian Richard Kearney's discussion of the anatheistic wager: the foundational moment in Abrahamic religions when the divine stranger manifests as an unheralded sacred guest. Her chapter considers the dramatic portrayal of an improbably hospitable Persia in The Travels of the Three English Brothers (1607) by John Day, George Wilkins, and William Rowley; and in dialogue with the seemingly hostile Venetian terrain found in Shakespeare's Othello and The Merchant of Venice. An integral component of peaceful and just coexistence is exercising hospitality toward the stranger, yet in Othello and Merchant such hospitality is merely narrated, while hostility is frequently performed. Ultimately, Kaufman argues that by reading Shakespeare's narrations of bidden hospitality through parallel scenes of manifest hospitality between English Christians and Persian hybrid-Muslims in Travels, a more nuanced vision of early modern religious pluralism emerges.

In "Hospitality in Twelfth Night: Playing at (the Limits of) Home," Joan Pong Linton combines Tracy McNulty's gendered intervention into the 
hospitality relationship with treatments of the messianic by Walter Benjamin and Giorgio Agamben. In Twelfth Night, Olivia's household exemplifies Illyrian inhospitality, being headed by an unmarried hostess who has cloistered herself from the world. Closer examination reveals a noble house in disrepair, overrun by male dependents all having designs on her body as property up for grabs. Yet in the first meeting between Olivia and Viola (disguised as Cesario), the two quickly fall to playful mockery of hospitality and courtly rituals. In this face-to-face encounter, the two women play at the limits of home and hospitality, each bringing "home" a stranger as an anagrammatic version of herself. Their encounter brings into play two biblical unveilings that locate home and hospitality within a larger political theology. The first links Olivia to Susanna, the biblical heroine and Christ figure in a long tradition of sermons and ballads, whose public unveiling in a rigged trial re-poses Olivia's domestic predicament as a question of justice. The second is the Pauline anticipation in 1 Corinthians of seeing God face to face, a subtext emerging in Feste's last song, which recalls Paul's use of the image of the child becoming man. Even as Paul's message-also a focus of Kaufman's essay-culminates in a call to love as the force drawing together the community of Christians, so Feste's song, in mediating between the play and the audience, calls both communities, imperfect as they are, into their messianic potential. Attention to biblical connections allows us to discern a subtextual, figural energetics of the theater, rendered through devices of comic disproportion and sacred parody, where the Shakespearean whirligig is charged with shards of messianic time, and small shifts in positions and dispositions register perceptible and purposeful difference.

In "Thinking Hospitably with Timon of Athens: Toward an Ethics of Stewardship," the closing essay of the volume, Michael Noschka rethinks hospitality in the present moment by way of a return to an earlier definition: hospitality as stewardship. Stewardship is used here in the Judeo-Christian scriptural sense of the term, as respect for and care of an other. Hospitality as stewardship emphasizes relationality over economic arrangements, whereas hospitality in our contemporary milieu typically tends toward an economic register that is decidedly materialist. Monetized definitions fall short of hospitality's ethical imperative, because they do not consider human personhood beyond material bodies and material needs. An alternative means of recouping hospitality is available via stewardship in its scriptural inflection. Noschka's essay considers hospitality in a composite archive: Timon of Athens, cognitive theories of hospitality management, and Judeo-Christian scripture. Theater both enacts and promotes reflective thought, and as Shakespeare's most steward-centric play, Timon represents the problem of materialist hospitality in distinctly visceral fashion. Cognitive theories of hospitality management provide terminological frameworks, while also revealing the ethical limitations of materialist thinking about hospitality. Cognitive research in hospitality management shows that we think about hospitality in relation to "servicescapes" before we experience 
emotional responses to hospitable actions. Noschka argues that Timon's failure to enact hospitality beyond the material stages our own contemporary misapprehension of what hospitality is and could be.

The question of what might make a hospitable text is implied throughout this collection, in which a number of scholars shelter, spinning out tales and commentaries for the reader. It is our hope that we editors act as harbingersnot, let's hope, of Macbeth's variety, but rather in the sense of rushing ahead to fashion a welcoming space to consider hospitality as a subject of present importance. How does one make a place for another, in acts of dialogue and exchange, in the space of the page? How do writers and readers (and playwrights and directors and actors) create scenes and acts of hospitality? How does the inhospitable sometimes aid this process, as the inhospitality of Macbeth's characters encourages the hospitality of being its audience? Here are some tapestries, some forks and plates. Enter, sit. Make of them what you will.

\section{Notes}

The idea for this collection developed out of a seminar on Shakespeare and Hospitality held at the 2013 Shakespeare Association of America conference; we are grateful to the Association, and to the seminar's participants and auditors for contributing to a lively and lasting conversation. The editors also wish to thank Shaina Trapedo for her help in preparing the manuscript.

1. Macbeth, ed. Nicholas Brooke (Oxford: Oxford University Press, 1990). Further references to the play are to this edition and are noted parenthetically in the text.

2. Mary Hill Cole, The Portable Queen: Elizabeth I and the Politics of Ceremony (Amherst: University of Massachusetts Press, 1999), 43. The first meaning for "harbinger" in the Oxford English Dictionary $(O E D)$ is "one who provides lodging; an entertainer, a host" (1); the Knight Harbinger was an officer in the Royal Household until 1846 (OED 2). The sense of a harbinger as a forerunner or announcer is metaphoric (OED 3). On the "appareling" of spaces for theatrical performance, see John Astington, English Court Theatre 1558-1642 (Cambridge: Cambridge University Press, 1999), 93-94.

3. On Renaissance England as a cloth culture, see Ann Rosalind Jones and Peter Stallybrass, Renaissance Clothing and the Materials of Memory (Cambridge University Press, 2000).

4. On state beds and their importance in Shakespeare, see Sasha Roberts, "'Let me the curtains draw': The Dramatic and Symbolic Properties of the Bed in Shakespearean Tragedy," in Staged Properties in Early Modern English Drama, ed. Jonathan Gil Harris and Natasha Korda (Cambridge: Cambridge University Press, 2002), 153-74.

5. Michael Mullin, "Stage and Screen: The Trevor Nunn Macbeth," Shakespeare Quarterly 38, no. 3 (Autumn 1987): 350-59. Many critics have explored hospitality in Macbeth: see, for example, J. P. Dyson, "The Structural Function of the Banquet Scene in Macbeth," Shakespeare Quarterly 14, no. 4 (Autumn 1963): 369-378; Paul Kottman, "Hospitality in the Interval: Macbeth's Door," Oxford Literary Review 18, no. 1 (July 1996): 87-115; Chris Meads, Banquets 
Set Forth: Banqueting in English Renaissance Drama (Manchester: Manchester University Press, 2001); Lisa Hopkins, "Household Words: Macbeth and the Failure of Spectacle," Shakespeare Survey 50 (1997): 101-110; Katherine Knowles, "Appetite and Ambition: The Influence of Hunger in Macbeth," Early English Studies 2 (2009): 1-20; Julia Reinhard Lupton, "Macbeth's Martlets: Shakespearean Phenomenologies of Hospitality," Criticism 54, no. 3 (Summer 2012): 365-76; James Heffernan, Hospitality and Treachery in Western Literature (New Haven: Yale University Press, 2014).

6. On chairs and stools in Shakespeare, see Julia Reinhard Lupton, "The Renaissance Res Publica of Furniture," in Animal, Vegetable, Mineral, ed. Jeffrey Jerome Cohen (Washington, DC: Punctum Books, 2012), 213-30.

7. Heffernan, Hospitality, 130.

8. For example, Gervase Markham, A Health to the Gentlemanly Profession of Servingmen; or, The Servingmens Comforts (London: 1598), D1v.

9. On the latter point, see B. J. Sokol, Shakespeare and Tolerance (Cambridge: Cambridge University Press, 2008).

10. Immanuel Kant, To Perpetual Peace (Indianapolis: Hackett, 2003); Émile Benveniste, "Hospitality," in Indo-European Language and Society, trans. Elizabeth Palmer (London: Faber and Faber, 1973). On hospitality in Renaissance theater and culture, see, for example, Felicity Heal, Hospitality in Early Modern England (Oxford: Oxford University Press, 1990); Patricia Fumerton, Cultural Aesthetics: Renaissance Literature and the Practice of Social Ornament (Chicago: University of Chicago Press, 1991); Daryl Palmer, Hospitable Performances: Dramatic Genre and Cultural Change (West Lafayette, IN: Purdue University Press, 1992); C. Anne Wilson, ed., Banqueting Stuffe (Edinburgh: Edinburgh University Press, 1991); Michel Jeanneret, A Feast of Words: Banquets and Table Talk in the Renaissance, trans. Jeremy Whitely and Emma Hughes (Chicago: University of Chicago Press, 1991); Heather Dubrow, Shakespeare and Domestic Loss Cambridge: Cambridge University Press, 1999); Wendy Wall, Staging Domesticity: Household Work and English Identity in Early Modern Drama (Cambridge: Cambridge University Press, 2002); Richard Wilson, "Making Men of Monsters: Shakespeare in the Company of Strangers," Shakespeare 1.1-2 (2005): 8-28; Joel Hecker, Mystical Bodies, Mystical Meals: Eating and Embodiment in Medieval Kabbalah (Detroit: Wayne State University Press, 2005); Catherine Richardson, Domestic Life and Domestic Tragedy in Early Modern England: The Material Life of the Household (Manchester: Manchester University Press, 2006); David Ruiter, "Shakespeare and Hospitality: Opening The Winter's Tale," Mediterranean Studies 16 (2007): 157-77; Joan Fitzpatrick, Food in Shakespeare: Early Modern Dietaries and the Plays (Aldershot: Ashgate, 2007); Lisa Celovsky, "Ben Jonson and Sidnean Legacies of Hospitality," Studies in Philology 106, no. 2 (Spring 2009): 178-206; Geraldo U. de Sousa, At Home in Shakespeare's Tragedies (Aldershot Ashgate: 2011); Kevin Curran, "Feeling Criminal in Macbeth," Criticism 54, no. 3 (Summer 2012): 391-401; David Goldstein, Eating and Ethics in Shakespeare's England (Cambridge: Cambridge University Press, 2013); and Julia Reinhard Lupton, "Hospitality," in Early Modern Theatricality, ed. Henry Turner (Oxford: Oxford University Press, 2013): 423-41.

11. For contemporary responses to theoretical issues in hospitality, see, for example, Emmanuel Levinas, Totality and Infinity: An Essay on Exteriority, trans. Alphonso Lingis (Pittsburgh: Duquesne University Press, 1969); Levinas, 
Otherwise than Being: Or, Beyond Essence, trans. Alphonso Lingis (Pittsburgh: Duquesne University Press, 1998); Jacques Derrida, "Hostipitality," in Acts of Religion, ed. Gil Anidjar (New York: Routledge, 2002), 356-420; Derrida and Anne Dufourmantelle, Of Hospitality (Stanford: Stanford University Press, 2000); Derrida, Adieu to Emmanuel Levinas, trans. Pascale-Anne Brault and Michael Naas (Stanford: Stanford University Press, 1999); Mireille Rosello, Postcolonial Hospitality: The Immigrant as Guest (Stanford: Stanford University Press, 2002); Giorgio Agamben, The Time That Remains (Stanford: Stanford University Press, 2005); Seyla Benhabib et al., Another Cosmopolitanism, ed. Robert Post (Oxford: Oxford University Press, 2006); Douglas H. Knight, The Eschatological Economy: Time and the Hospitality of God (Grand Rapids, MI: Eerdmans, 2006); Tracy McNulty, The Hostess (Minneapolis: University of Minnesota Press, 2007); Amos Yong, Hospitality and the Other: Pentecost, Christian Practices, and the Neighbor (Maryknoll, NY: Orbis 2008); Maurice Hamington, "Toward a Theory of Feminist Hospitality," Feminist Formations 22, no. 1 (Spring 2010): 21-38; Richard Kearney and James Taylor, eds., Hosting the Stranger: Between Religions (New York: Continuum, 2011). 
Part I

Oikos and Polis 
This page intentionally left blank 


\title{
1 "Will You Walk in, My Lord?" \\ Shakespeare's Troilus and Cressida and the Anxiety of Oikos
}

\author{
Andrew Hiscock
}

Thy Tigrish mind who could haue well detected?

In mortall breasts so great barbaritie?

What forward sprite could haue such spight suspected?

In hospitalitie hostilitie? ${ }^{1}$

Here, the grieving Croesus, eponymous hero of one of William Alexander's "monarchicke tragedies" (1604), gives way to an outpouring of vitriolic outrage against his guest-a guest whose desire for a boar hunt unwittingly brought about the very thing that the king had long sought to avert, the death of the royal heir. In direct comparison with a host of early modern texts, notably playtexts, this key moment of narrative crisis in Alexander's closet drama urged early seventeenth-century readers to interrogate the culturally charged commitment of hospitality-how the yielding of time, space, and sustenance might impose acutely frictional obligations of investment, custody, stewardship, and public witness. Indeed, such dramas as Croesus intervened in a vigorous, if thorny debate in post-Reformation Britain in which if the clergy were forsaking their ethical and spiritual duties of keeping a good table for guests and strangers, those who came to replace them among the ranks of the nation's elite could prove equally unforthcoming in their offerings of good cheer: Elizabeth's premier minister, William Cecil, Lord Burghley, cautioned his eldest son, "Touching the government of thy house, let thy hospitality be moderate and according to the measure of thine own estate, rather plentiful than sparing - but not too costly." " Given this parlous state of affairs, it may come as no surprise that one J. B., "Doctor of Phisicke," chose to include "hospitalitie" ("Entertainement of strangers, good house keeping") in his English expositor teaching the interpretation of the hardest words vsed in our language (1616); and it has remained one of the most anxiety-ridden undertakings on into the twenty-first century where the welcome extended to the guest, the stranger, xenos ( $\xi \dot{\varepsilon} v o \varsigma)$, continues to test sorely the many and various understandings we may have of the cultural scaffolding which supports our collective lives. ${ }^{3}$

Building upon the ideological foundations of ancient Greek society where both mortals and disguised immortals might present themselves in need of a domestic haven and just treatment (dikaiosuné), the Latin world also came to invest deeply in the ius hospitii not only as an axis along which 


\section{8}

to gauge the mores of human exchange in a given society, but also as one of the organizing principles that should define the mission civilisatrice of the Roman cultural project. Indeed, Ladislaus J. Bolchazy argued forcefully that "The ius hospitii brought Romans from magico-religious xenophobia to altruism ... with its insistence on kind treatment of a stranger, and its latent concept of the brotherhood of man, the ius hospitii became one of the factors which paved the way for the reception of the more advanced and reasoned teachings of Stoicism and Christianity." 4 Arthur Golding's translation of the stoical Seneca's De Beneficiis (1578), for example, not only acknowledged "how sacred a thing the table of hospitalitie is," but reminded its early modern readers strategically of the manner in which the poor scholar Aeschines paid most fulsome tribute to the great Socrates: "Syr, I fynd nothing of sufficient worthinesse too bestowe vppon you, and by that meanes I feele myself too bee poore. Therfore I giue vntoo you the only thing that I haue, euen myself." ${ }^{5}$ Whereas Seneca concerned himself with the moral treasures that might be secured by adopting the identities of host, patron, and donor, Cicero was more given to appreciating at length the social value of "this bond of hospitalitie." In early modern translations of works such as De officiis and the Epistles by the revered "Tully," the reader was repeatedly reminded that hospitality was not only an obligation and a fundamental adhesive agent in Roman culture, but that this "domesticall friendship" might operate as a remarkably efficient vehicle for social preferment:

For it is (as methinketh) verie seemlie, noble mennes howses to be open for noble geastes. And $\mathrm{y}^{\mathrm{t}}$ also is an honour to the state: that outelandish men in our cite do not want this kinde of liberalitie. It is also exceeding profitable to them, who honestlie desire to be able to do much: to preuaile in power, and fauour, by their geastes, amonge forein nations. ${ }^{6}$

With the rise of Christianity, the most cursory glance at the New Testament would encounter an analogous veneration for the rites of hospitality: "And whosoeuer shall giue to drinke vnto one of these litle ones, a cup of cold water onely, in the name of a disciple, verily I say vnto you, hee shall in no wise lose his reward" (Matthew 10:42); "Use hospitalitie one to another without grudging" (1 Peter 4:9). Moreover, among a number of the Church Fathers, Ambrose pondered with due care and attention the obligations of what Seneca's Aeschines had proffered as an ultimate gesture of magnanimity (magnus animus, greatness of spirit), the absolute extension of the self to the other: "It is most seemly in the eyes of the whole world that the stranger should be received with honour; that the charm of hospitality should not fail at our table ... A man ought therefore to be hospitable, kind, upright, not desirous of what belongs to another, willing to give up some of his own rights if assailed, rather than to take away another'." ${ }^{7}$ Lest it should slip the 
attention of the early modern reader, Erasmus for his part also underlined in his Paraphrases "vpon the Newe Testament" that the Old Testament equally paid long and ample tribute to the virtue of generous welcome: "hospitalitie is highlye commended before God, in so much that hereby Abraham deserued to receyue vnwares Angels to lodgyng when he thought he had done that good tourne and pleasure vnto men." ${ }^{8}$

Interestingly, it is becoming increasingly apparent that such acts of hospitality (often with mixed responses among the host population) were being practiced at a national level in the second half of the sixteenth century. Bindu Malieckal has estimated recently, for example, that "between 1550 and 1585, up to 50,000 refugees may have entered England, including Dutch and Belgian Protestants fleeing Spanish persecution, as well as Italian Protestants." 9 Thus, if Robert Robinson's allegorical treatise The vineyarde of vertue (1579) drew attention to the "plant Hospitalitie" ("Hospitalitie is so thankfully acceptable before God, that not so much as a cup of colde water giuen with good wil, but it shall bee rewarded againe and recompensed five folde"), in his own textual hortus conclusus, William Vaughan went one step further at the turn of the century, contending in The golden-groue moralized in three bookes (1600) that this "plant" constituted "the chiefest point of humanity."10

\section{Resisting Welcome}

At the dawn of the modern period, George Bernard Shaw argued that Troilus and Cressida was a work that revealed its author to be "ready and willing to start the twentieth century if the seventeenth would only let him"11; and indeed it is this classicized, medievalized play's arresting ability to engage at very close quarters with the traumas with which early modernity and late modernity was/is wrestling that will govern the present discussion. If, later in that twentieth century which Shaw evoked, Walter Benjamin urged presciently that "the 'state of emergency' in which we live is not the exception but the rule," in later decades Jacques Derrida, among a number of eminent thinkers, sought precisely to anatomize this state of emergency in terms of the contrary motions that might lie at the heart of the relationship of host and guest, of "hostipitality."12 If Derrida insisted that "what belabors and concerns hospitality at its core ... like a promise as much as like a threat, what settles in it, within it, like a Trojan horse, the enemy (bostis) as much as the future, intestine hostility, is indeed a contradictory conception ... a contradiction of welcoming itself," ${ }^{13}$ Shakespeare's own theater of hospitality (which is enacted both within and without the Trojan walls) focuses most particularly upon the figures of the resisting host, the unruly guest and the violation of sacred obligations: we are transported to a dramatic world where an unreceptive "Achilles stands i'th'entrance of his tent" and his overlord Agamemnon is advised "to pass strangely by him, / As if he were forgot" $(3.3 .38-40) .^{14}$ 


\section{0}

In direct comparison with these Greek practices of inhospitality, within the walls of Troy the "stubborn-chaste" Cressida has to be cajoled to involve herself in the more intimate hosting envisaged by her uncle Pandarus for Prince Troilus: "Yet I hold off. Women are angels, wooing; / Things won are done" (1.1.93, 1.3.277-278). Indeed, later in the narrative, her father, the xenos, the defector Calchas is compelled to bargain with the distracted Greeks to press his demands for recompense as their agreed guest: "I have abandoned Troy, left my possessions, / Incurred a traitor's name ... / And here, to do you service, am become / As new into the world, strange, unacquainted" $(3.3 .5-6,11-12)$. In these ways, Shakespeare's play unveils a human environment deeply exercised by excessive appetites for control and subjugation-for the righting of past wrongs, the claiming of territories and bodies-and thus one wholly unfitted for the enacting of the sacred rites of hospitality. This is a world in which households are constituted on stage through bitter flyting, conspiratorial conniving, and physical menace:

AJAX: Thou bitch-wolf's son, canst thou not hear? Feel, then.

THERSITES: being beaten. The plague of Greece upon thee, thou mongrel beef-witted lord!

Interestingly, if the Latin hostis perplexingly sustained meanings of both alien and enemy, Daryl W. Palmer has signaled an additional equivocation that lays at the heart of the early modern cultural lexicon: "The word host derives from the Latin hospes and hospitis. In these etymological origins and in Renaissance usage, the single term host signifies both host and guest." 15 Indeed, the present inquiry into one of Shakespeare's problem plays proposes that the thorny contemporary debate (in which thinkers such as Derrida, Lévinas, and Ricoeur have been notable participants) concerning the volatile power relationships between the welcomer and the welcomed and the uncomfortable kinship of "hospitalitie hostilitie," was already being shaped and developed in early modern performative cultures some four hundred years before.

\section{The Theater of War}

Dramatic narrative, whether presented on page or onstage, offers a perfect medium for such inquiries given that the medium in question thrives upon the enacting of oppositional values, beleaguered human experience, and beguiling modes of seduction. As we have seen, the performance, or what Julia Reinhard Lupton has persuasively termed the "domestic theatre," 16 of hospitality is envisaged by Derrida as one riddled with internal contradictions:

on the one hand, hospitality must wait, extend itself toward the other ... But, on the other hand, the opposite is also nevertheless true, 
simultaneously and irrepressibly true: to be hospitable is to let oneself be overtaken ... Visitor and invited, visitation and invitation, are simultaneously in competition and incompatible. ${ }^{17}$

It swiftly becomes apparent that this attritional cycle of systolic and diastolic human exchange dominates William Alexander's account of progressive collapse in a culture of hospitality: here, at the joyless court of Croesus, guests such as Solon, Aesop, and Adrastus find themselves alienated in quick succession and, to crown the royal achievement, the whole realm finally succumbs to Persian invaders. However, elsewhere, in the midst of the seemingly ceaseless butchery that Troilus and Cressida evokes, audiences are also repeatedly called upon to ponder the performative status and function of hospitality in a strife-ridden landscape. Indeed, whether the focus is upon armed hostilities led by Darius or upon spectacular acts of aggression between Trojans and Greeks, in both texts we are introduced into morally unremarkable dramatic worlds where everyday life is governed by ruthless competition and the premature inheritance of superlative identities and privileged claims to ownership.

At the opening of Shakespeare's play, we are presented with jaded political communities compromised by impure motivation, political lethargy, and failing humanity: the Greek commander Agamemnon bears ample witness to the fact that "we come short of our suppose so far / That after seven years' siege yet Troy walls stand" (1.3.11-12). If the Volscian servant in Shakespeare's later Coriolanus insists "Let me have war, say I. It exceeds peace" (4.6.218), such sentiments would garner little support in the warweary communities on the Dardan Plain in the earlier play. Troilus himself queries, "Why should I war without the walls of Troy, / That find such cruel battle here within?" (1.1.2-3). Moreover, late Elizabethan audiences were thoroughly acquainted with the tribulations surrounding failing military campaigns and the reluctance of a great many to enter the profession of arms, as the Captain in Robert Barret's The theorike and practicke of modern warres (1598) bore witness: "For long peace hath bred Securitie; securitie, carelesse mindes; carelesse mindes: contempt of warre; contempt of warre, the dispising of souldiarie and Martiall discipline; the dispising of Martiall discipline, vnwilling minds."18

"Beginning in the middle," Shakespeare's bitter dramatic narrative compels us into the company of "princes orgulous, their high blood chafed"; and the subsequent "broils," or theaters of choler, with which we are confronted are wholly shaped by the trafficking of bodies, whether initially across the waters of the Aegean or subsequently across the waters of the Styx (Prol. 28, 2, 27). Unsurprisingly, in this iron age of war, households are among the first casualties when everyday selves are translated into warriors. The abduction/seduction/reduction of Troy's newest citizen and trophy wife, Helen, is merely a re-enactment of the spiriting away of Priam's sister, Hesione, a generation earlier in retaliation for her father's, Laomedon's, broken vows 


\section{Andrew Hiscock}

to the Gods and to Hercules. If Paris's later supplication to the Greeks for the return of his aunt Hesione proved fruitless, he remained determined to return home with a woman of royal blood, namely, Menelaus's queen of Sparta: "To ransack Troy, within whose strong immures / The ravished Helen, Menelaus' queen, / With wanton Paris sleeps; and that's the quarrel" (Prol. 8-10). In due course in Shakespeare's play, as in every other account of Troy's demise, this brokering of political ambitions back and forth across the Mediterranean with the currency of female bodies leads to the relinquishing of the trunks of dead warriors year after year from both Troy and Greece to the doleful waters of the Underworld.

In The Politics, Aristotle construed the "war-mad man" in consciously Homeric terms as "having no family, no law, no home," 19 and thus draws particular attention to the ways in which recourse to violence burns away and dissolves what he viewed as the fundamental principles of life in human society. If Shakespeare's medievalized dramatic world may bear little evidence of an acquaintance with Aristotelian argumentation per se, it is thoroughly conversant with the realities of failed states and fugitive existences that the theater of war engenders. Equally significantly, the riven nature of Shakespeare's warring societies is repeatedly expressed in terms of the crises being negotiated within the microcosm of the elite householdoikos (or in the later Latin world, domus). The oikos was widely conceived as the basic building block of a city-state or polis: in the ancient world, it emerged both as the powerfully symbolic distillation and negotiation of the primary animating forces within a given society. Moreover, such thinking formed an integral element of the cultural legacy that antiquity was seen to have bequeathed to succeeding ages. The celebrated Spanish humanist Juan Luis Vives asserted authoritatively in De officio mariti (1529), "what a commoditie is the wife vnto $\mathrm{y}^{\mathrm{e}}$ husband, in ordering of hys house, $\&$ in gouerning of hys familie $\&$ housholde? by this cities are edified \& buylded;" 20 and, at the close of the sixteenth century, John Dod and Robert Cleaver contended without fear of contradiction in A godly forme of houshold government (first published 1598) that "An Houshold is as it were a little Commonwealth, by the good gouernment whereof, Gods glorie may be aduanced, and the commonwealth which standeth of seuerall families benefited; and all that liue in that familie receiue much comfort and commoditie." 21

If the concept of oikos nourished a mythology of belonging in the ancient world, linked to reserved spaces of dwelling (of family, property and buildings-oikia kai chorion ${ }^{22}$ ), it was evident from the founding of this mythology that the household community and estate supported multiple functions of reception and entertainment as well as opportunities for withdrawal (otium) and intimacy. This division of the spoils of domestic life was widely appreciated in the early modern period, as Francis Bacon indicated in his Essayes: "Houses are built to Liue in, not to Looke on ... I say, you cannot haue a Perfect Pallace, except you haue two seuerall Sides; A Side 
for the Banquet ... And a Side, for the Houshold: The One for Feasts and Triumphs, and the Other for Dwelling." ${ }^{23}$ At the outset, immanent in such symbolic figurations of oikos was the assertion that the survival of these little commonwealths remained apotropaic, keeping death (that is, the deadly competition for space and bodies) at bay. Nonetheless, if this cultural ideal was deployed conceptually as a prime guarantor of a society's enduring integrity, it also frequently became the scene in which bitter conflicts of legal, political, spiritual, and kinship allegiances might be contested-conflicts which in the ancient world, as Richard Seaford has persuasively demonstrated, could be communicated in the shape of the unruly god Dionysus. This wayward son of Zeus, source of the frenzied bakkheia, might simultaneously be viewed as "destroyer of the household" and, in his associations with the unruly collective life of the thiasos, as "a god of the whole polis." 24

In the conflicted world of postwar theorizing, Michel Foucault insisted that "the anxiety of our era has to do fundamentally with space." However, he (in direct comparison with Shakespeare's play) did not restrict the parameters of his investigations to questions of topographical, architectural, or somatic spaces-though these spaces certainly do exist in Troilus and Cressida as we are invited imaginatively to penetrate "Priam's six-gated city- / Dardan and Timbria, Helias, Chetas, Troien / And Antenorides-with massy staples / And corresponsive and fulfilling bolts" (Prol. 15-18). Indeed, elsewhere, there are scenes of teichoskopia (or military spectating from vantage points) where Pandarus, for example, tempts Cressida to "an excellent place" "Shall we stand up here and see them as they pass toward Ilium?' 1.2.172-175), or Helen and Hecuba are known to have resorted "to the eastern tower, I Whose height commands as subject all the vale, / To see the battle" (1.2.2-4). Rather, Foucault's readers were forcefully reminded that "we live inside a set of relations that delineates sites which are irreducible to one another and absolutely not superimposable on one another ... Thus it is that the theater brings onto the rectangle of the stage, one after the other, a whole series of places that are foreign to one another." ${ }^{25}$ The theatrical analogy which Foucault pursues here, drawing attention to the slipping and sliding of material and ideological spaces upon each other as human experience is constituted, is of particular interest when considering a work such as Troilus and Cressida-a work that is profoundly concerned with the construction of social spaces of reception in and exclusion from matrices of intimate relations. In Shakespeare's play world, ambitions to illuminate the dark corners of these ancient societies may, and frequently do, come to fruition with the assistance of intermediaries, eavesdroppers, and voyeurs with the invaluable resources of the unfettered imagination. Indeed, Pandarus occupies himself throughout the dramatic narrative with his self-appointed role of host to the illicit loves of the protagonists: "I will show you a chamber with a bed; which bed, because it shall not speak of your pretty encounters, press it to death: away!" (3.2.202-204). Elsewhere, the petulant Achilles, for example, "Grows dainty of his worth and in his tent / Lies mocking our 
designs. With him Patroclus, / Upon a lazy bed the livelong day / Breaks scurril jests," while Ajax too is "grown self-willed, and ... / ... keeps his tent like him" (1.3.145-148, 188-190). In his Essayes, mindful of Aristotelian thinking, Francis Bacon argued that "Whosoever is delighted in solitude, is either a wilde Beast, or a God. For it is most true, that a Naturall and Secret Hatred, and Auersation towards Society, in any Man, hath somewhat of the Sauage Beast." ${ }^{26}$ Achilles clearly assumes both of these identities at different points and communicates them most often in his unwillingness to share his dissaffected oikos with the broader society of the Greeks. At such points, we may be reminded of a similarly rebellious lord who found himself holed up with his familiars in the aftermath of a flawed demonstration of military leadership: "the Earl of Essex is now returned to London, and it is much noted how his doors are set open to all comers ... many captains, men of broken fortunes, discontented persons." 27

More generally in Shakespeare's bitter comedy, two warring societies are yielding simultaneously to the beguiling pleasures of military and erotic service in order to safeguard key cultural investments and to gratify cherished pleasure principles. Nonetheless, in the midst of this tale of abductions, invasions, and parleys, it matters little whether we keep company with the besieged Trojans or the estranged Greeks; we are forced to engage with the overarching narrative of violent trauma from a markedly domicentric perspective. $^{28}$

\section{Broken Vows and Broken Laws}

When early modern minds contemplated these remote societies locked in combat over the fates of Hesione and Helen, they were often little given to celebrating the decorum with which the hostilities unfolded-certainly not the chivalric courtesies that Chaucer and Shakespeare introduced into the emotionally charged intrigues of Troilus and Criseyde or Troilus and Cressida. While much has been justly made of the Tudor mythologizing of its Trojan origins looking back to the flight of Brute from the Mediterranean world of his forefathers and to the founding of Brutayne, there is every reason to believe that the immured space of the Priam's six-gated city may have generated a much greater breadth of response in Tudor and Stuart society than signaling a powerful site of cultural belonging. Indeed, immured spaces might constitute on certain occasions the precise inverse of the early modern subject's desired state of well-being. In an ambitious and revealing discussion, Mary Thomas Crane has underlined in a timely manner that "Critics have paid less attention to the fact that real privacy, especially for illicit activities, was, until well into the seventeenth century, most often represented as readily attainable only outdoors." ${ }^{29}$ Turning in a more focused manner to those locked in war-torn societies, we may be reminded that Marlowe's Tamburlaine rails at those who live "idle in the wallèd towns, / Wanting both pay and martial discipline" ${ }^{30}$; and, with just a little less vehemence, 
William Harrison submitted in his account of castles and fortified places in his Description of England (1587):

it is not the nature of a good Englishman to regard to be caged vp as in a coope, and hedged in with stone wals, but rather to meet with his enimie in the plaine field at handstrokes, where he may trauerse his ground, choose his plot, and vse the benefit of sunne shine, wind and weather, to his best aduantage $\&$ commoditie. ${ }^{31}$

Here, Harrison is thinking specifically about the playing out of armed hostilities, but may also be offering food for thought more generally about the varietas in early modern constructions of belonging and dwelling. The slippery nature of such discourses has been revealingly highlighted by Michael C. Schoenfeldt, for example, in his account of Spenser's Castle of Alma in The Faerie Queene ("surrounded by enemies and under constant siege") to which even the knights errant Arthur and Guyon initially fail to gain access (2.11.10): "An ethic of hospitality here collides with an image of self in a continual state of war." ${ }^{32}$ Like Spenser, Shakespeare in Troilus and Cressida has a consuming interest in unpicking the ethics of hospitality for wider scrutiny in scenes of siege warfare and in those of potentially equal import unfolding in domestic chambers privy to the inspection of fewer pairs of eyes. Interestingly, if, during the reign of Henry VIII, Sir Thomas Wyatt sailed back to his native capital, "to the town which Brutus sought by dreams," and Henry Howard, Earl of Surrey, called "to mind the navy great / That the Greeks brought to Troia towne,"33 their contemporary Sir Thomas Elyot was recalling for this same generation of Henrician England that although "ardentelye belouyd of Stenobea, the wyfe of Pretus kynge of Ephyra," Bellerophontes would not succumb to an adulterous relationship, "fearyng the vengeance of Iupiter god of hospitalitie." 34 Subsequently, his Tudor reader was reminded that, "Hospitalis Iupiter, was soo called, bycause straungers or Gestes whan they were yll intreated in theyr lodginges, they called hym to witnes, desyringe hym to reuenge hym."35

This concern with Iupiter xenius and the sanctity of the laws of hospitality over which he presided would surface in many and various guises throughout the early modern period. In Lysimachus and Varrona (1604), for example, John Hind had his characters "beseech Iupiter Xenius the patron of hospitalitie, and protectour of strangers, to blesse our labours, prosper our attempts." 36 Philip Sidney's own prose romance celebrated "the right honest hospitalitie which seemes to be harboured in the Arcadian brests" and the "sacred protection" of a guest; and, in his poetic collection Parthenophil and Parthenophe (1593), Barnabe Barnes summoned the figure of Atlas who "(through fierce crueltie/And breache to lawes of hospitalitie / When lodging to a straunger he denied) / Was turned to a stonie mountaine straight." ${ }^{37}$ Elsewhere, Philemon Holland's translation of Ammianus Marcellinus's The Roman historie (1609) underlined that "Among other 
Attributes given to Iupiter, one was Xenius, or Hospitalis, the Superintendent, as it were, of guests, and their entertainement. So religious they were in old times, that a guest once received should be inviolable"; and Shakespeare's Lucrece "coniures' the brute Tarquin 'by high Almightie Ioue, / ... By holie humaine law, and common troth, / By Heauen and Earth, and all the power of both: / ... Quoth shee, reward not Hospitalitie, / With such black payment."38

Moreover, there was a growing number of voices who were willing to attribute the basest of motives to the Trojan prince who set out to redeem Hesione from her Greek hosts. Thomas Fenne, for example, was not disposed to celebrate the supposedly Trojan ancestry of his nation and railed in Fennes frutes (1590) that it was "a disgrace, and also a foule discredit, to Englishmen ... to deriue their pedigree from such an vnfaithfull stock, who were the chiefe causers of their own perdition." In Fenne's account, despite being "right Princely intertained by Menelaus King of Lacedemon, who right honorably banqueted and feasted both him and his companions" and benefiting from the fact that the king had "commaunded Helena his beautiful Queen so entertaine her guest in his absence," Paris was prey throughout to his "owne lecherous motion": "for which friendly entertainment and gentle courtesie ... to requit the gentle King stole away from thence his wife Helena, whom he entirely loued." 39 Thus, both memory and morality play the young prince false, and this lust-crazed guest violates a sacred undertaking with his host. Elizabeth I's godson, Sir John Harington, quipped in verse that if "Pastor Paris" had seen the loveliness of one Olympia ("all was as white as milk, / As smooth as Iuory, and as soft as silke"), "For Helena he had not cared at all, / Nor broke the bonds of sacred hospitalitie, / That bred his country wars and great mortalitie." 40 Furthermore, the severing of such sacred ties are uppermost initially in Helen's own thoughts in Thomas Heywood's Troia Britanica (1609) when she rebuts the amorous advances of the Trojan prince, declaring, "Dar'st thou (Oh shamelesse) in such heynous wise, / The Lawes of Hospitality despise? And being a straunger, / from thy Countries reach, / Solicite a chast wife to Wedlocks breach?" 41

Understandably, when George Chapman renewed Homer's epic poems for British readers with new translations in the vernacular from 1598 onward, due attention was necessarily afforded to 'humane Hospitality,' given the thematic emphases of his source texts: "Guest? If one much wurse / Arriu'd here then thy selfe; it were a curse / To my poore meanes, to let a Stranger tast / Contempt, for fit food." ${ }^{42}$ Moreover, this acquaintance with the sacred laws of antiquity did not forsake Shakespeare's contemporary when he turned his attentions to the stage. In The Revenge of Bussy D'Ambois (1613) Clermont queries, "Who was in fault for all the slaughters made / In Ilion, and about it? Were the Greekes? / Was it not Paris rauishing the Queene / Of Lacedæmon? Breach of shame and faith? / And all the lawes of Hospitalitie?" ${ }^{3}$ It might also be added that, during his long years of captivity in the Tower, Walter Raleigh devoted himself principally to the narrative labors of The History of the World (1614) and, for his own part, also found 
much with which to take issue in the received accounts of the travails of Agamemnon's Greece and Priam's Troy. Rather than indulging his reader's appetites for heroic exploits and tender insights into domestic havens, the chronicler all too often chose to shine a light upon the chaotic conditions of existence of these warring races and their barbaric appetites for scavenging and violation:

I thinke that Paris had no regard, either to the rape of Europa, Medoea, or Hesione: but was meerely incited by Venus, that is, by his lust, to doe that which in those dayes was very common. For not onely Greekes from Barbarians, and Barbarians from Greekes, as Herodotus discourseth, but all people were accustomed to steale women and cattell, if they could by strong hand or power get them ... It is true that in these times Greece was very saluage, the inhabitants being often chaced from place to place, by the captaines of greater Tribes: and no man thinking the ground whereon hee dwelt his owne longer than hee could hold it by strong hand ... briefly, Greece was then in her infancie. ${ }^{44}$

Thus, rather than uniformly celebrating the thoughts, words, and deeds of antique heroes, this agon of everlasting memory continued to generate widely differing responses in early modern England. Moreover, equally interestingly, the proliferating narratives surrounding Paris and Helen might not only trigger a meditation upon the nature of violated hospitality, but lead to a wide-ranging and biting critique of all parties drawn into the deadly fray around the walls of Troy.

\section{"What's Aught, But as 'tis Valued?": Combative Spaces and Household Transactions}

Shadowing in many ways the steps of Chaucer's Troilus and Criseyde, Shakespeare introduces us into a medievalized world of figures distracted by their appetites for self-gratification. Neither of these narratives is principally concerned with clamorous armies locked in combat on killing fields or with aggrieved disputants on Olympus. Instead, the landscape of the city-state and the Dardan Plain is punctuated by countersites of individuated human interest-palace chambers and city walls, encampments, and conspiratorial gatherings: if Troilus himself acknowledges the pressing business of the "sport abroad," he has no hesitation in stating his true inclinations: "Better at home, if 'would I might' were 'may'” (1.1.110-111).

Chaucer's Troilus is found at points in the long narrative poem to pathologize his trauma by memorially remapping the architectural spaces of his besieged city ("Lo, yonder saugh ich last my lady daunce; / And in that temple, with hire eyen cleere, / Me kaughte first my righte lady dere. I ... And at that corner, in the yonder hous, Herde I myn alderlevest lady deere" [5.565-567, 575-576]). However, in contrast, Shakespeare's 


\section{8}

play urges us to attend to what Foucault termed as sets of relations that delineate sites. Moreover, such discursively constructed sites may be specifically gendered in nature, as Henry Smith urged in A Preparative to Marriage (1591): "the Cocke flieth abroad to bring in, the Dam sitteth vpon the nest to keepe al at home. So God hath made the man to trauaile abroade, and the woman to keepe home ... for the mans pleasure is most abroade, and the womans within." ${ }^{45}$ Such divisions of labor are ranged clearly into view in the couplings and wranglings that describe the oikoi of Shakespeare's dramatic world. Andromache urges, for example, "Unarm, unarm, and do not fight to-day," whereas Hector only makes further investment in the extramural, public domain of military heroism- "Get you in. / By all the everlasting gods, I'll go!" (5.3.3-5). If, locked in the court world of Cleopatra's charms, Shakespeare's Antony complains that he has relinquished his role as one of the triple pillars of the Roman world, similarly enslaved to desire, Troilus in the earlier play bemoans that it is "womanish" (1.1.103) to be from the battlefield, and deems himself "weaker than a woman's tear, / ... Less valiant than the virgin in the night" $(1.1 .9,11)$ in devoting himself to the cult of love within the city's walls. (Interestingly, it soon becomes apparent that his witty mistress, the lady Cressida, knows exactly what it is for an unseasoned man "to be baked with no date in the pie" [1.2.247-248].) Elsewhere, the in-tented Achilles is maligned as "over-proud / And under-honest," liable (like the female body) to "pettish lunes, his ebbs, his flows" $(2.3 .121-122,128)$. Disdaining the Greek society that pays him little homage, Achilles refuses to "untent his person" (2.3.165). Ulysses and then Ajax are sent to the wrathful warrior, but to little avail: the King of Ithaca subsequently submits, "There is no tarrying here; the hart Achilles / Keeps thicket" (2.3.252-253).

The reiterative narrative and locus amoenus of this play world is the presentation, but most frequently yearned-for penetration, of reserved, intimate space: Troilus reflects at the beginning of the play, "I cannot come to Cressid but by Pandar, / ... Between our Ilium and where she resides, / Let it be called the wild and wand'ring flood" (1.1.91, 97-98). In both the Greek and Trojan communities there persists an obsessive interest in willing oneself to be a guest in order to gain prized access to household space and knowledge: the gatekeeper Patroclus informs Agamemnon that the intemperate Achilles is "Within his tent; but ill disposed," whereas the ever watchful Ulysses snarls, "We saw him at the opening of his tent. / He is not sick" (2.3.74, 82-83). Furthermore, when the Trojan guest Aeneas is granted safe passage into the palpable disarray of the Greek camp, he pointedly queries whether it is possible here even to differentiate the confidential from the commonplace, nay, the master from the minion:

AGAMEMNON: What would you 'fore our tent?

AENEAS: Is this great Agamemnon's tent, I pray you? ...

Which is the high and mighty Agamemnon? ... 
AGAMEMNON: Sir, you of Troy, call you yourself Aeneas? ...

What's your affair, I pray you?

AENEAS: Sir, pardon, 'tis for Agamemnon's ear.

AGAMEMNON: He hears naught privately that comes from Troy.

$(1.3 .215-6,232,245,247-9)$

Significantly, Agamemnon seeks to resolve this Trojan challenge to Greek chivalry and galling estimation of Greek confusion by asserting his authority with the public, indeed ostentatious performance of hospitality. By assuming the role of host, the King of Mycenae aims to subject the unruly stranger and, into the bargain, his quarrelsome retainers to his overlordship: "Fair Lord Aeneas, let me touch your hand; / To our pavilion shall I lead you first. / ... Yourself shall feast with us before you go / And find the welcome of a noble foe" (1.3.304-305, 308-309).

Shakespearean dramaturgy frequently draws attention to the recidivist behaviors of those seeking to secure precarious claims to sovereignty: purposefully and repeatedly Henry IV and Henry V confuse militarism with government, for example, and in the tragedies, figures such as Macbeth and Claudius can choose to promote their own royal legitimacy through spectacles of welcome and feasting. Interestingly, at the close of Troilus and Cressida, Agamemnon returns to this favored strategy of power assertion with the tactical performance of hospitable entertainment (of inter tenere or holding together ${ }^{46}$ ) when he greets Hector as his guest in the wake of the gladiatorials with Ajax: "all you peers of Greece, go to my tent; / There in the full convive we ... / Beat loud the tabourins, let the trumpets blow, / That this great soldier may his welcome know" (4.5.271-272, 275-276). However, as the Jacobean preacher Thomas Adams cautioned in his sermon The sacrifice of thankefulnesse (pub. 1616), the assembled company might do well to be on its guard when faced with such histrionic displays: "Gallant prodigalitie, like fire in flaxe, makes a great blaze, a hote shew: but Plaine hospitality, like fire in solide wood, holds out to warme the poore: because God blesseth it." ${ }^{47}$ Indeed, this was a sentiment that had already been explored at length by William Vaughan in The Golden-Grove (1600), a near contemporary of Shakespeare's bitter comedy:

They are greatly deceyued, who thinke, that hospitality doth consist in slibber-sauces, in spiced meates, or in diuersities. For these are nought els, saue fooleries, and fond wasting of goods, whereby the flesh is prouoked to lechery, \& becommeth altogether inflamed, massy, and diseased. Further, experience teacheth, that none are more subiect to sicknesses, then they, that gurmaundize and feed on sundry kindes of dishes ... Good hospitality therefore consisteth not in gluttonous diuersities, but rather in one kind of meat, in clothing the naked, and in giuing almes vnto the poore. ${ }^{48}$ 


\section{0}

In Troilus and Cressida extravagant displays of greeting and good cheer are keenly contrasted with more intimate scenes of invitation, reception, and predation elsewhere in this unraveling world. The schemer Achilles, for example, plans to send "sweet Patroclus" to summon Thersites so that he may inform Ajax "T'invite the Trojan lords after the combat / To see us here unarmed. I have a woman's longing, / An appetite that I am sick withal, / To see great Hector in his weeds of peace" (3.3.238-241)—in the event, the cynic Thersites arrives unbidden and thus abbreviates the aspiring host's line of command.

Interestingly, while much is made in narrative terms of Cressida's entry into the sexual market of Troy with the greeting of the brothel, "Will you walk in, my lord?" (3.2.59), the role of the sexually available woman, the hetaira or courtesan in the ancient world, clearly unpicks any publicly acknowledged codes of hospitality, scrambling our understanding of the identities of host and guest: indeed, Cressida herself teasingly queries amid the assembled company of her Greek suitors at the end of the play, "In kissing, do you render or receive?" (4.5.37). In his discussion of the thriving sexual trade in classical Athens, Simon Goldhill highlights importantly that the "hetaira is a particularly difficult figure for the dynamics of male authority. Beautiful and desirable-but who's in charge? Not biddable nor buyablebut perhaps persuadable. Male self-determination-self-sufficiency-is set at risk by the figure of the hetaira." ${ }^{49}$ In Shakespeare's play world, Troilus finds himself incapable of self-government on account of his unruly passions, and this most unaccommodated man roams histrionically about the city in search of a most particular invitation: "I stalk about her door / Like a strange soul upon the Stygian banks / Staying for waftage" (3.2.7-9). In due course, the quick-witted Cressida repeats "Will you walk in, my lord?" playing willing hostess to an all-too willing guest- "O Cressida, how often have I wished me thus!" $(3.2 .95,60)$. Nonetheless, in this scene of lightly veiled passions, all the agents (including Pandarus) are at a loss to determine whether it is better to give than to receive, even to differentiate meum from tuum: "My lord, I do beseech you, pardon me; / 'Twas not my purpose thus to beg a kiss" (3.2.132-133).

In the event, some early modern eyes, such as Thomas Nashe's in Christ's Tears over Jerusalem (1593), had little difficulty in identifying the true nature of the welcome on offer in such dwellings of the nation's capital: "London what are thy Suburbes but licensed Stewes' and complained of the 'Prouident Iustices, to whom these abuses redress appertaineth, take a little paines to visite these houses of hospitality by night." ${ }^{50}$ However, for others, such practices might not only be discovered in licensed premises: if little inclined to visit Troy's stews, the watchful Pandarus seems to know the customs of the country and gleefully remarks on entering his niece's apartments, "What's all the doors open here? ... How now, how now, how go maidenheads?" $(4.1 .20,24)$. Indeed, in his lively sermon The Devil's Banquet (1614), Thomas Adams argued forcefully that the trade of the 
"harlot" was a vicious mimicking of the practices of hospitality, for at the threshhold "shee presents her selfe to the common eye" and as for customers, "they come in troupes to her." 51 Furthermore, in direct comparison with the monitored movements of the lady Cressida ("Walk into her house. / I'll bring her to the Grecian presently" 4.3.5-6), the prostitute might err about the city and constitute a moveable feast for the eyes of those beyond the bounds of oikos:

in the Citie. Whoredome, scornes to liue obscurely in the Suburbs: Shee hath friends to admit her within the walles. Nay, in the high places of the Citie: in the largest streetes, populous and popular houses ... The feast is like to be good when an Harlot is the Hostice ... A Harlot then, bids, and feasts, and kils: what other successe can be looked for? The Deuill hath feasted the wicked, and now the wicked feast the Deuill. ${ }^{52}$

The teasing Pandarus exclaims to his witty niece "One knows not at what ward you lie," and receives the quicksilver response from his auditor, "Upon my back, to defend my belly" (1.2.249-251). If the whole of Shakespeare's tragicomedy is exercised by the depredations brought about by the trafficking of female bodies (Hector argues at the opening of the Trojan Council's debate, "Brother, she is not worth what she doth cost / The holding" [2.2.51-52]), by the end of the play Cressida at last finds herself among feverish supporters and eager clients in the Greek camp. Thersites quips that the subtle lady has learned her lesson well how to survive in a grubby, conflict-ridden society-“a juggling trick: to be secretly open” (5.2.26).

\section{"Twere Better She Were Kissed in General": Concluding Thoughts}

If, in the interwar period, the Russian Marxist critic A. A. Smirnov found Shakespeare's comedy to be a "motley and contradictory play," over half a century later in a wide-ranging and incisive discussion Barbara Bowen was drawing attention to "the misogyny and somatophobia of Troilus and Cressida's analysis of war." ${ }^{53}$ Lest any doubt should persist, Paola Pugliatti has concluded more recently that "Troilus and Cressida is a deeply unpleasant play." ${ }^{54}$ Whatever the justness of these contentions, if this bitter comedy (like The Taming of the Shrew and Measure for Measure, for example) has proved on occasions a little too intractable for prevailing taste cultures, it may indeed be that we have to rethink our critical lines of attack, rather than ensure that such texts are refin'd for the stage or deemed unfit for present consumption.

The classical scholar Richard Seaford has tellingly underlined that " $[t]$ he communality of the polis is established at the expense of women, who, without power in the public sphere, were easily imagined as adhering excessively to the household and as resisting their public powerlessness" ${ }^{55}$; and, mining 


\section{2}

an analogous vein in their own thought-provoking accounts of Shakespeare's tragicomedy, René Girard stresses that "Cressida cannot become once again 'the thing ungain'd' that she used to be, but she can be lost to someone else" and Dympna Callaghan argues equally persuasively that "there is a level at which [Shakespeare's Cressida] refers not to women but to the masculinities she negotiates." ${ }^{56}$ Elsewhere, pondering in detail the final challenges of this dramatic narrative (i.e., its remorseless investment in indeterminacy) where Cressida is handed on from the clutches of one Greek chieftain to the next, Alexander Leggatt has explored revealingly the manner in which "Cressida seems broken and re-made before our eyes through the pressure of relationship ... in her own way as unreadable as Lavinia. Calculation, fear, sexual interest, catatonic stupor-what lies beneath that silence?" 57 Proliferating perspectives on an exceedingly perplexing dramatic moment, we might add, could this scene not also constitute an inverted ritualization of anakalupteria whereby the bride is unveiled and accompanied in procession to her future household? Or are we being presented with a bitter parody of ritualized gift-giving (or dora) in this definitive entry of the lady Cressida into the fiercely competitive world of adult sexuality? The possible angles of vision upon this remarkably elusive text are very far from being exhausted.

Generations of critics have taken up a challenge upon which they believe Shakespeare's text insists, that of anatomizing its divided dramatic world into clearly delineated factions: E. M. W. Tillyard, for example, contended that we are thrust into the company of "antique" Trojans and Greek "new men"; Emil Roy unveiled a dramatic world of "warring halves, pitting Greek aggression against Trojan sensuality"; and Thomas G. West contrasted the materiality of the Greeks' outlook with the Trojans' continuing investment in acts of faith or "of the will." ${ }^{58}$ However, it remains all too possible that Shakespeare initially proposes these tempting, reassuring polarities (like those of fifteenth-century England and France, of Capulets and Montagues, of Belmont and the Rialto, for example) only to indicate the imperfect nature of such navigational expectations in these darkly complex worlds. The present discussion has concerned itself with the ways in which a dominant cultural discourse, in this case hospitality, might offer a fruitful lens through which to contemplate the perceivedly corrosive undertaking of Troilus and Cressida. It is clear that in the early years of the seventeenth century when Shakespeare tested the boundaries of both tragedy and comedy, the plays he produced returned repeatedly to question the status and function of domestic welcome: Brabantio in Othello queries vehemently the liberties that the Moor has taken as his guest; elsewhere, Gloucester protests to the "naughty lady" Regan in King Lear, "I am your host. / With robbers' hands my hospitable favours / You should not ruffle thus" (3.7.36, 38-40). Moreover, Paul Kottman has illuminated the "perverse hosting" operational in Macbethinterestingly, this is a practice that is equally in evidence in a rather different key in another work from these years in Shakespeare's career, The Merry Wives of Windsor. ${ }^{59}$ However, like the tragedies, Troilus and Cressida 
presents a vision of life in human society in which loss is thematic, and the welcoming and expelling of strangers and guests from reserved spaces of dwelling is integral to all their dramatic narratives. In the final scenes of this problem play of Greeks and Trojans, we are urged to compare and contrast the yielding of Cressida to Greek competitive hospitality and the yielding of Hector to a more bloodthirsty version of it: "I'll heat his blood with Greekish wine tonight, / Which with my scimitar I'll cool tomorrow. / Patroclus, let us feast him to the height" (Achilles, 5.1.1-3).

At the beginning of this discussion, we considered how the ancient and early modern worlds identified strategic cultural capital in the sacred bonds of hospitality, how it came to constitute an indication of superlative human exchange, or of what Emmanuel Lévinas has termed for more contemporary audiences, the interhumain: "L'interhumain proprement dit est dans une non-indifférence des uns aux autres, dans une responsabilité des uns pour les autres ... La rencontre d'Autrui est d'emblée ma responsabilité pour lui." ${ }^{60}$ If this absolute realization of human potential through self-extension to others was acknowledged, as we have seen, in writings from antiquity, such as Seneca's De Beneficiis, it does not pass unrecognized among the inmates of Shakespeare's dramatic world: indeed, Ulysses' reading matter forces him to consider that "no man is the lord of anything, / Though in and of him there be much consisting, / Till he communicate his parts to others" (3.3.116-118). Nonetheless, if Lévinas promoted a condition of existence in which "Nous sommes ainsi responsables au-delà de nos intentions," 61 Shakespeare summons the terrifying prospect of the inverse of this postulate. The residents of his dramatic world can guess at what hospitality might be, but it becomes all too evident that they know not what it is in substantive, human terms. With his wonted jaundiced vision of the world, Ulysses asserts that "Time is like a fashionable host / That slightly shakes his parting guest by th'hand, / And with his arms outstretched as he would fly / Grasps in the comer" (3.3.166-9); and the dying Hector protests, "I am unarmed. Forgo this vantage, Greek" (5.9.9). At the close of this play where the two cultures converge in a deadly banquet, the bereft Troilus petitions to be an eavesdropper, if he cannot be a guest, at the revelry in Menelaus's tent where Diomedes feasts after his own manner, giving "all gaze and bent of amorous view / On the fair Cressid" (4.5.28-3). To its very conclusion, Shakespeare's dramatic narrative concentrates upon those threatened with or forced to endure exclusion from designated spaces of hospitality.

A beleaguered Aeneas protests in the closing moments of Shakespeare's play, "Stand, ho! Yet are we masters of the field. / Never go home; here starve we out the night" (5.11.1-2). However, Thomas Fenne had already reported for his late Elizabethan readers that at the Sack of Troy, this future founder of empires would leave the burning city "contemning all other things of great valew and estimation, [carrying] out with him the gods of hospitality." 62 This defining scene for millennia to come of the violent unraveling of oikos (or domicide) had been envisaged from the outset 


\section{Andrew Hiscock}

of the dramatic narrative where Troilus finds himself abandoned in "the wild and wand'ring flood" and the jaundiced words of Ulysses mourn "how many Grecian tents do stand / Hollow upon this plain" (1.1.98, 1.3.79-80). ${ }^{63}$ Indeed, the very community of oikos, the family itself, is at no point protected from the wider dissolution of the warring societies on the Dardan Plain: like her near contemporary Helena in All's Well That Ends Well, Cressida is able and willing in extremis to foreswear the most sacred ties of kinship, testifying, "I have forgot my father. / I know no touch of consanguinity; / No kin no love, no blood, no soul so near me / As the sweet Troilus" (4.2.97-100).

Recent critical debate has been much exercised whether this play, "too far ahead of its time," ${ }^{4}$ may ever have found a Jacobean home: the "Never Writer" imparts "news" to the "Eternal Reader" in the opening pages of the 1609 quarto that this most demanding play was "never staled with the stage, never clapper-clawed with the palms of the vulgar, and yet passing full of the palm comical"- and even the reception of Troilus and Cressida into the First Folio does not seem to have been ensured from the outset. ${ }^{65}$ In the face of adversity, Cressida cleaves to "the strong base and building of [her] love" as "the very centre of the earth, / Drawing all things to it" (4.2.104-106), but this is all to no avail in a landscape condemned to destruction. In this doomed dramatic world, there is no space that may not be claimed, no act of hospitality that may not be revoked.

CRESSIDA: Who's that at door? Good uncle, go and see.-

My lord, come you again into my chamber.

You smile and mock me, as if I meant naughtily.

\section{Notes}

1. William Alexander, Earl of Stirling, The monarchicke tragedies Croesus, Darius, The Alexandraean, Iulius Caesar (1607), sig. G2v . I would also like to take this opportunity to thank Julia and David for kindly inviting me to be a part of their most hospitable project.

2. William Cecil, Lord Burghley, Certain Precepts for the Well Ordering of a Man's Life (ca. 1584), in Louis B. Wright (ed.), Advice to a Son. Precepts of Lord Burghley, Sir Walter Raleigh, and Francis Osborne (New York: Folger Shakespeare Library/Cornell University Press, 1962), 10.

3. J. B. (John Bullokar), An English expositor teaching the interpretation of the hardest words vsed in our language. With sundry explications, descriptions, and discourses. By I.B. Doctor of Phisicke (1616), sig. H6 ${ }^{\mathrm{V}}$.

4. Ladislaus J. Bolchazy, Hospitality in Early Rome (Chicago: Ares Publishers Inc., 1977), 35.

5. Seneca, The woorke of the excellent philosopher Lucius Annaeus Seneca concerning benefyting that is too say the dooing, receyuing, and requyting of good turnes. Translated out of Latin by Arthur Golding (1578), sigs. R1 ${ }^{\mathrm{v}}, \mathrm{B} 2^{\mathrm{v}}$. 
6. See, respectively, Cicero, The familiar epistles of M.T. Cicero Englished and conferred with the: French Italian and other translations (1620), 719; Cicero, Marcus Tullius Ciceroes thre bokes of duties to Marcus his sonne, turned out of latine into english, by Nicholas Grimalde (1556), 89.

7. St. Ambrose, "Three Books on the Duties of the Clergy," in Rev. H. de Romestin (ed. and trans.), A Select Library of Nicene and Post-Nicene Father of the Christian Church, 2nd series: vol. 10 St. Ambrose, Select Works and Letters (Oxford/ New York: James Parker/Christian Literature Co., 1896), see, respectively, pp. 59 (II.xxi.103), 59-60. (II.xxi.106).

8. Erasmus, The seconde tome or volume of the Paraphrase of Erasmus vpon the Newe Testament conteynyng the epistles of S. Paul, and other the Apostles: wherunto is added a paraphrase vpon the reuelacion of $S$. John (1549), fol. $25^{\mathrm{V}}$.

9. Bindu Malieckal, "Boat People': Wars of Religion, Women Refugees, and Shakespeare's The Tempest," in Shakespeare and Immigration, ed. Rueben Espinosa and David Ruiter (Farnham: Ashgate, 2014), 114.

10. See, respectively, Richard Robinson, The vineyarde of vertue (1579), sig. 30v; William Vaughan, The golden-groue moralized in three bookes (1600), sig. P6 ${ }^{\mathrm{r}}$.

11. "Preface to Plays Unpleasant," in Prefaces by Bernard Shaw, George Bernard Shaw (London: Constable \& Co. Ltd., 1934), 692.

12. See, respectively, Walter Benjamin, "Theses on the Philosophy of History," in Illuminations, ed. Hannah Arendt, trans. Harry Zohn (London: Collins/Fontana, 1973), 259; Jacques Derrida, Acts of Religion, ed. Gil Anidjar (New York: Routledge, 2002), 358.

13. Derrida, Acts of Religion, 359.

14. All textual references to Troilus and Cressida are taken from the following edition: William Shakespeare, Troilus and Cressida, ed. David Bevington (London: Cengage Learning/Arden, 1998).

15. Daryl W. Palmer, Hospitable Performances. Dramatic Genre and Cultural Practices in Early Modern England (West Lafayette, IN: Purdue University Press, 1992), 3.

16. Julia Reinhard Lupton, "Macbeth's Martlets: Shakespearean Phenomenologies of Hospitality," Criticism 54, no. 3 (2012 Summer): 372.

17. Derrida, Acts of Religion, 360-2.

18. Robert Barret, The theorike and practike of moderne warres discoursed in dialogue wise (1598), 2.

19. Aristotle, The Politics, ed. and trans. T. A. Sinclair and T. J. Saunders (London: Penguin, 1983): 1.2.59-60.

20. Quoted here from the early modern English translation: Juan Luis Vives, The office and duetie of an husband, made by the excelle[n]t philosopher Lodouicus Viues, and translated into English by Thomas Paynell (1555, 1st pub. 1550), sig. A7v .

21. John Dod and Robert Cleaver, A godly forme of houshold government (1621), sig. $A 7^{r}$.

22. See Michael Jameson, "Private Space and the Greek City," in The Greek City from Homer to Alexander, ed. Owen Murray and Simon Price (Oxford: Clarendon Press, 1990), 171. Evelyne Scheid-Tissinier also stresses that "L'oikos ... désigne à la fois la famille et le domaine foncier qui fait vivre cette famille." See Evelyne Scheid-Tissinier, "Laos et dèmos, le peuple de l'épopée," Antiquité Classique71 (2002), 1-26 (p. 3). In this context, see also Cheryl Anne Cox, Household Interests: Property, Marriage Strategies, and Family Dynamics in Ancient Athens (Princeton: Princeton University Press, 1998), esp. pp. 68-78. Additionally, in an 
interesting discussion, Michael Modarelli attends specifically to the gender politics of the oikos in Troilus and Cressida. See Michael Modarelli, "Untune That String, and Hark What Discord Follows': The Tragedy of Troilus and Cressida's Fractured Oikos," Cahiers Elisabéthains 74 (Autumn 2008), 1-10.

23. XLV "Of Building," in Francis Bacon, The essayes or counsels, ciuill and morall (1625), 257.

24. Richard Seaford, "Dionysus as Destroyer of the Household: Homer, Tragedy and the Polis," in Masks of Dionysus, ed. Thomas H. Carpenter and Christopher A. Faraone, 115-46 (Ithaca/London: Cornell University Press, 1993). In this context, see also J. Roy, "Polis and Oikos in Classical Athens," in Greece and Rome 46, no. 1 (April 1999): 1; Adele C. Scafuro, "Introduction: Bifurcations and Intersections," in Athenian Identity and Civic Ideology, ed. Alan L. Boegehold and Adele C. Scafuro (Baltimore: Johns Hopkins University Press, 1994): 1-20.

25. Michel Foucault, "Of Other Spaces,” trans. Jay Miskowiec, Diacritics 16, no. 1 (Spring 1986): 23, 25.

26. XXVII "Of Friendship," in Bacon, The essayes, 149.

27. Quoted in Lena Cowen Orlin, Private Matters and Public Cultures in PostReformation England (Ithaca: Cornell University Press, 1994), 7.

28. For further discussion of the domicentric, see David E. Sopher, "The Landscape of Home: Myth, Experience, Social Meaning," in The Interpretation of Ordinary Landscapes. Geographical Essays, ed. D. W. Meinig (New York: Oxford University Press, 1979): 134.

29. Mary Thomas Crane, "Illicit Privacy and Outdoor Spaces in Early Modern England," Journal for Early Modern Cultural Studies 9, no. 1 (Spring 2009): 5.

30. Christopher Marlowe, Tamburlaine the Great, Part I, ed. J. S. Cunningham (Manchester: Manchester University Press, 1981), 1.1.146-147.

31. William Harrison, "Description of England," in The first and second volumes of Chronicles comprising 1 The description and historie of England, 2 The description and historie of Ireland, 3 The description and historie of Scotland: first collected and published by Raphaell Holinshed, William Harrison, and others: now newlie augmented and continued (with manifold matters of singular note and worthie memorie) to the yeare 1586. by Iobn Hooker aliàs Vowell Gent and others. With conuenient tables at the end of these volumes, Raphael Holinshed (1587), 195.

32. Michael C. Schoenfeldt, Bodies and Selves in Early Modern England: Physiology and Inwardness in Spenser, Shakespeare, Herbert, and Milton (Cambridge: Cambridge University Press, 1999), 53-54.

33. See, respectively, Sir Thomas Wyatt, "Tagus, farewell, that westward with thy streams," in Selected Poems of Sir Thomas Wyatt, Sir Thomas Wyatt, ed. Hardiman Scott (New York: Routledge/Carcanet Press, 2003), line 5, p. 27; Henry Howard, Earl of Surrey, "When raging love with extreme pain," in Henry Howard, Earl of Surrey. Selected Poems, Henry Howard, Earl of Surrey, ed. Dennis Keene (New York: Routledge/Carcanet Press, 2003), lines 7-8, p. 65.

34. See entry for "Bellerophontes," in Bibliotheca Eliotae Eliotis librarie, Sir Thomas Elyot (1542), sig. F2 ${ }^{\mathrm{v}}$.

35. Elyot, Bibliotheca, sig R $5^{\mathrm{v}}$.

36. John Hind, The most excellent historie of Lysimachus and Varrona, daughter to Syllanus, Duke of Hypata, in Thessalia Wherin are contained the effects of 
fortune, the wonders of affection, and the conquests of incertaine time (1604), sig. $\mathrm{H} 1^{\mathrm{v}}$.

37. See, respectively, Sir Philip Sidney, The Countesse of Pembrokes Arcadia (1593), sigs. $35^{\mathrm{r}}, 235^{\mathrm{v}}$; Barnabe Barnes, Parthenophil and Parthenophe (1593), 86.

38. See, respectively, Ammianus Marcellinus, The Roman historie ... Done by Philemon Holland (1609), sig. D4r; William Shakespeare, Lucrece (1594), sig. E2 ${ }^{\mathrm{r}}$.

39. Thomas Fenne, Fennes frutes which worke is deuided into three seuerall parts; the first, a dialogue betweene fame and the scholler... The second, intreateth of the lamentable ruines which attend on warre... The third, that it is not requisite to deriue our pedegree from the unfaithfull Troians, who were chiefe causes of their owne destruction: whereunto is added Hecubaes mishaps, discoursed by way of apparition (1590), sigs. $85^{\mathrm{v}}, 87^{\mathrm{v}}$.

40. Anthologized in the following miscellany: Robert Albott, Englands Parnassus (1600), 410-1.

41. Thomas Heywood, Troia Britanica (1609), 215.

42. Book XIV, in Homer's Odysses. Translated according to ye Greeke by. Geo[rge] Chapman, Homer (1615), 212.

43. George Chapman, The Revenge of Bussy D'Ambois 2.1.211-5. See George Chapman, The Plays of George Chapman. The Tragedies with 'Sir Gyles Goosecappe'. A Critical Edition, ed. Allan Holaday, G. Blakemore Evans, and Thomas L. Berger (Cambridge: D. S. Brewer, 1987), 465.

44. Sir Walter Raleigh, The History of the World (London: Walter Burre, 1634 [1614]). See, respectively, 2.14.2.382 and 2.13.7.368. References are to book, chapter, section, and page.

45. Henry Smith, A preparatiue to mariage (1591), 54-55.

46. For further discussion here of the etymology of entertainment, see Palmer, Hospitable Performances, 3.

47. Thomas Adams, The sacrifice of thankefulnesse A sermon preached at Pauls Crosse ... anno 1615 (1616), 24.

48. Vaughan, The golden-groue, sigs. P6v-P7r.

49. Simon Goldhill, "The Seductions of the Gaze: Socrates and his Girlfriends," in Kosmos: Essays in Order, Conflict, and Community in Classical Athens, ed. Paul Cartledge, Paul Millett and Sitta von Reden (Cambridge: Cambridge University Press, 1998), 113.

50. Thomas Nashe, Christ's teares ouer Ierusalem Whereunto is annexed a comparatiue admonition to London (1613), 157, 161.

51. Thomas Adams, The deuills banket [i.e. banquet] (1614), 3.

52. Adams, The deuills banket, 4-6.

53. See, respectively, A. A. Smirnov, Shakespeare: A Marxist Interpretation, trans. S. Volochova et al. (New York: The Critics Group, 1936), 80; Barbara E. Bowen, Gender in the Theater of War. Shakespeare's 'Troilus and Cressida' (New York/ London: Garland Publishing, 1993), 161.

54. Paola Pugliatti, Shakespeare and the Just War Tradition (Farnham: Ashgate, 2010), 169.

55. Seaford, "Dionysus as Destroyer," 137.

56. See, respectively, René Girard, A Theatre of Envy (New York: Oxford University Press, 2000 [1991]), 130; Dympna Callaghan, Shakespeare Without Women: Representing Gender and Race on the Renaissance Stage (London: Routledge, 2000), 13. 


\section{Andrew Hiscock}

57. Alexander Leggatt, Shakespeare's Tragedies. Violation and Identity (Cambridge: Cambridge University Press, 2005), 85.

58. See, respectively, E. M. W. Tillyard, Shakespeare's Problem Plays (London: Penguin, 1970), 16-17; Emil Roy, "War and Manliness in Shakespeare's Troilus and Cressida," Comparative Drama7 (1973): 108; Thomas West, "The Two Truths of Troilus and Cressida," in Shakespeare as Political Thinker, ed. John E. Alvis and Thomas G. West (Durham, NC: Carolina Academic Press, 1981), 127, 129, 139.

59. Paul Kottman, "Hospitality in the Interval: Macbeth's Door," The Oxford Literary Review18, no. 1-2 (1996), 98.

60. Emmanuel Lévinas, Entre Nous. Essais sur le penser-à-l'autre (Paris : Grasset, 1991), 111, 113. Translation: "The interhuman, properly speaking, lies in a non-indifference of one to another, in a responsibility of one for another ... From the start, the encounter with the Other is my responsibility for him." See Emmanuel Lévinas, On Thinking-of-the-Other, trans. Michael B. Smith and Barbara Harshav (London: Athlone Press, 1998), 100, 103.

61. Lévinas, Entre Nous, p. 14. Translation: "Thus we are responsible beyond our intentions." See Lévinas, On Thinking-of-the-Other, 3.

62. Fenne, Fennes frutes, 88.

63. In this context, see J. Douglas Porteous, "Domicide: The Destruction of Home," in The Home: Words, Interpretations, Meanings, and Environments, ed. David N. Benjamin et al. (Aldershot: Avebury, 1995), 151-61.

64. Shakespeare, Troilus and Cressida, ed. Bevington, 89.

65. Shakespeare, Troilus and Cressida, ed. Bevington, 120, 401ff. 


\title{
2 A Digression to Hospitality Thrift and Christmastime in Shakespeare and in the Literature of Husbandry
}

\author{
Jessica Rosenberg
}

Thrift, thrift, Horatio, the funeral bak'd meats

Did coldly furnish forth the marriage tables.

-Hamlet, 1.2.180-181

With these lines, Hamlet charges his mother with both bad hospitality and good housekeeping: she has observed the everyday imperatives of thrift but broken the ritual calculus of mourning. By overlaying wedding onto funeral, Gertrude has failed at hospitality's core law: not just failing to mourn, but neglecting to treat every hospitable occasion as exceptional. Hamlet is not alone in recognizing Gertrude's imperfect hospitality, but he does see more clearly what may be at stake in the haste of her remarriage. Hamlet's words respond in partial correction to the observation that Horatio has just made: "Indeed, my lord, it follow'd hard upon." For Hamlet, Gertrude has not only moved too quickly from funeral to wedding, she has, in practice, conflated them. Gertrude's "seconding" brings about a category confusion - of sex and death, wedding and funeral-but it also interrupts the natural sequence that should run from father to son. In Horatio's language, the marriage of Gertrude and Claudius moves hastily: it follows "hard upon" the funeral. Hamlet's image, though, is locked in time: in it, time seems to have stopped; marriage and funeral are overlaid as if the meats served at a funeral stayed in place on the very table where, having grown cold, they are served upon occasion of a wedding. What's moving hard and fast for Horatio is locked in a cruel stillness for Hamlet—cold and tabled.

But there remains something strange in the idiom to which Hamlet turns to condemn his mother's marriage to Claudius. Curiously, the Prince twice gives the name "thrift" to the phenomenon of remarriage. Later in the play, Hamlet will lend similar language to the Player Queen: "The instances that second marriage move / Are base respects of thrift, but none of love" (3.2.177-178). Gertrude's thrift suggests she has subscribed to an economy of equivalence that is indifferent to the particularity of husbands and fathers-an equivalence against which Hamlet's exceptional and dilated mourning rebels. But why should Hamlet twice call upon this quotidian 
language of household management to name the offense of his mother, the Queen's, remarriage?

For a range of modern reciters, Hamlet's phrase has become shorthand for an economic way of thinking - an efficient epitome of the ideological triumph of thrift in the modern world. Echoing the styles of rational calculation that Max Weber saw in the spirit of capitalism, these first three words- "Thrift, thrift, Horatio"-deliver a cutting verdict on modernity itself. As Jacques Lacan writes in his essay on the play, Hamlet here names "something that has been overlooked in the Marxian analysis of economy, the dominant one for the thought of our time-something whose force and extent we feel at every moment: ritual values." 2 This third term becomes visible in its absence, the neglected other of modern capitalism. Slavoj Žižek cites Hamlet's phrase as shorthand for the historical shift into the modern era, answering the question "What, then, is the nature of the break with modernity?" 3 By adding an exclamation point and conscripting the phrase as a section heading, Žižek transforms it into an imperative by which his readers (as subjects of modernity) are likewise bound: "Thrift, thrift, Horatio!" He thus extends Hamlet's attack on his mother to a critique of modern capitalism, such that the passage marks the central fracture in modernity not as absence but as superfluity: thrift, he writes, always threatens to become miserliness. The virtue of control contains within it the inevitable vice of its uncontrolled practice. With these readings, Lacan and Žižek both take Hamlet's side. They agree that there is something either missing or contradictory in the thrift that Hamlet diagnoses in his mother's actions. Already ahead of his time, Hamlet's words seem to these twentieth-century readers to mourn not just his father but a lost way of thinking. ${ }^{4}$ It turns out that modernity, like Gertrude, has gotten a bad reputation by going to bed too quickly with the profit economy, forgetting the value of ritual dilation.

For Sigmund Freud, Hamlet's line articulates an imperative governing the operation of the unconscious, the principle of economy behind psychic condensation. When Freud cites this line in Jokes and Their Relation to the Unconscious he does so as part of a gloss on condensation; this joke becomes the epigrammatic key to all jokes. With this economism, Freud turns to a strategy of condensation in his own argument: "All these techniques are dominated by a tendency to compression, or rather to saving. It all seems to be a question of economy. In Hamlet's words: 'thrift, thrift, Horatio!'" 5 For Freud, thrift names a principle of psychic exchange, governing the equivalences behind puns and slips, but by the same stroke becomes an engine of excess. Symptoms may work according to a logic of condensation, but they are hardly bound by conditions of scarcity. Much like Polonius' sententious advice, thrift may stick to an ideology of minimalism, but—just as brevity may be the soul of wit (a passage that Freud also cites) - thrift tips quickly into excess (and its corollary, miserliness), the very paradox that Žižek sees enabling and plaguing modern capitalism. 
It is fitting perhaps that one third of the phrase epitomizing modern efficiency is redundant: thrift assumes imperative force in repetition (thrift, thrift!), as it is multiplied.

What these twentieth-century reciters have forgotten, however, is that Hamlet's words are already a citation. By choosing to characterize Gertrude's actions as "thrift," Hamlet invokes the genre of advice that is the term's home territory: early modern England's many guides to managing a household. "Thrift," in Hamlet's echo, sounds tawdry, shamefully out of scale when applied to the Danish royal household. ${ }^{6}$ Gertrude's remarriage is thus a double breach of decorum: she has transgressed the expectations of both her gender and her (regal) class. In Shakespeare's play and in these later citations, "thrift" declares an imperative as much as it names a principle: while it stands for a theory of value, it also calls upon those in earshot to obey those values. In context, Hamlet's phrase might be understood as either imperative or indexical: as an ironic exhortation to his friend, or as a damning diagnosis of his mother's behavior. Among twentieth-century critics, its repeated citation has often come with the addition of an exclamation point, a shift in mode to direct address that helps enable this rhetorical mobility. In the imperative mood, thrift itself becomes a kind of gift or offering (or, like many gifts, a burden)-a principle of economic possession in the process of rhetorical redistribution. That is, while property may be controlled, anyone can assert the law of its accumulation. An imperative reading would have come naturally to Shakespeare's audience, both because of the term's implicit normative force and because of the genre in which its qualities were most frequently set out: books of advice and instruction, addressed directly to husbands and sometimes huswives. The core principle of governance for the miniature state of the household, thrift carries legislative force within the domestic sphere. In this sense, the queen is further diminished by the form of the advice, and not just by its middlebrow content-that is, that she should have obeyed an imperative at all. Rather than act as sovereign, she has subjected herself to the humble demands of household rule. ${ }^{7}$

The misogynistic core of Hamlet's accusation lies in its central paradox: at the same time that Gertrude (a bad hostess) is not giving enough away, she is giving away far too much. As it extends a quotidian by-word for household order to the (dis)order of the royal Danish household, Shakespeare's play alights upon the same anxieties about excess that attached to thrift in the sixteenth-century literature of hospitality and housekeeping. The conflicted moral economy invoked in these two moments of the play repeats and extends a tension already central to the printed advice literature of husbandry and household management. Though thrift may stand as a general law of the household for most of the year, at occasions demanding hospitality, thrift represents not prudence but stinginess. As the two core values of what a household is supposed to do, thrift and hospitality are fundamentally at odds. In the examples I consider in this essay, a tension 
between the two imperatives-between spending and maintaining, giving out and taking in-is solved not by striking a prudential balance, but by manipulating the sequence of things, or suspending the passage of time. In this sense, the hospitable temporalities at work in the examples I consider here provide a suggestive counterpoint to the messianic time that Joan Pong Linton, in her essay in this volume, sees at work in Twelfth Nightanother seasonal drama. Hospitality is a virtue that, if well performed, can undermine the household. In its suspension of everyday household law, it is often hospitality (to paraphrase Polonius) that seems to dull the edge of husbandry.

In this essay, I consider the ways in which both the failures and successes of hospitality turn (as Hamlet suggests) on bad timing. In Hamlet and in a range of practical treatments of husbandry, the economic dilemma of hospitality is translated into a temporal problem-negotiated through formal, material, and ideological means as a dilation of the regular time of the household. A fascinating example of this is found in Thomas Tusser's A hundreth good pointes of husbandrie (1557), where the exceptional hospitality associated with Christmastime interrupts the regular time of the year and the expectations of household governance that accompany it. This conflict between expectations of spending and saving both organized and disrupted the temporality of domestic life in early modern England. In a household world in which the passage of time is marked by prudent accumulation and restraint, seasonal hospitality-especially Christmas, a time organized by imperatives of expenditure and open doors-must always be vexed. Like Hamlet's grief, holiday time is sanctioned as both necessary and exceptional. Various scholars have suggested that England's sense of seasonality was in flux in this period, transitioning away from a calendar shaped by regular religious and civic festivity. Early modern conflicts about moral economy took Christmas celebration as a special object: in its observance, a wasteful transgression of prudence, and in its breach, a miserly violation of hospitable obligation and charity. It could thus easily seem a break in the natural course of the year. As Marcellus says in Hamlet's opening scene, the time of Christmas is "so hallow'd and so gracious" that its movement almost seems to stop: "The bird of dawning singeth all night long: / And then, they say, no spirit dares stir abroad; / The nights are wholesome; then no planets strike, / No fairy takes, nor witch hath power to charm"(1.1.165-169). ${ }^{8}$ Traditionally the time of year when gentry expended their annual store in the charitable entertainments, the value and survival of "ancient hospitality" at Christmastime seemed urgently at stake in early modern England, as some critics attacked the vanity of festive entertainment, while others worried about the social effects of a decay in hospitality. Like Gertrude's bad hospitality, thrift resists such temporal dilation, while holiday festivity works by prying and holding open the passage of time. As it opens the doors of a particular moment in the year, hospitality is incited by the calendar but ignores its imperatives. 


\section{Holiday Unthrifts}

In Thomas Tusser's A hundreth good pointes of husbandrie, first published in 1557 and frequently expanded through the end of the century, Christmas is given a special status within a yearly calendar otherwise governed by thrift and prudence. Tusser responds to these competing systems with a dramatic formal intervention: following months of rhyming couplets on household thrift, a new section called "Christmas" breaks into the text at the end of December, interrupting the regular calendric progression of points and the lessons of accumulation that they impart. By the edition of 1573 , this section is significantly expanded and titled "A Digression to Hospitality." In the spirit of the season, these short poems instead emphasize the importance of giving to the poor and opening one's home. In a sharp contrast with the rest of the book, they are presented typographically and generically in the style of a lyric miscellany, a change in mode that formally plays out the principles of generosity and hospitality espoused in the poems themselves. In Tusser's rendering, however, the formal and temporal dilation performed by this poetic digression must be exceptional, a temporary reprieve from the everyday law and order of the household. In this sense, what Derrida calls the antinomy between the law of unlimited hospitality and the multiple and conditional laws of its application are echoed in the arrangement of the text itself. Tusser's "Digression to Hospitality" disrupts and loosens the form of the text, such that efficient thrift of the points and of their message opens onto the liberality of lyric miscellany and of radical holiday hospitality. For Derrida, "an act of hospitality can only be poetic," a suggestion to which this digression in the Pointes gives literal form. ${ }^{9}$ As the treatment of Christmas hospitality shows, the tension between thrift and hospitality is not always resolved by striking a prudential balance; instead Tusser, like Hamlet, negotiates it by means of formal digression and temporal dilation.

In Tusser's Pointes, the strange untimeliness of Christmas in both text and calendar follows from the way that the year itself is fitted to the demands of husbandry and thrift, the everyday accumulation of provision that (as he reminds his readers) enables the expenditure of winter feasting. Hospitality is a key step in Tusser's "Ladder to Thrift," but one to be kept in check: the husbandman must remember "To kepe good hospitality. / To hate all prodigality." ${ }^{10}$ This core principle of the household's moral economy is difficult to balance throughout the year, but comes to a head with the radical hospitality that Christmas occasions-or threatens. In The Anatomie of Abuses (1583), Philip Stubbes worries that holiday "fooleries" license excessive consumption and invert natural, sacred, and political order. In matters of expense and consumption, Stubbes argues, Christmas was a time just like any other time, and so one ought "not to swil and gull more that time tha[n] at any other time, not to lauish foorth more at that time, than at another times." Stubbes' repetition of the word undifferentiates time, performing 
the sameness among different times for which he is arguing and curbing the threat of unbridled consumption posed by exceptional time. Otherwise, such expenditures endanger not just moral and household integrity but the solvency of the commonwealth itself: "what dicing \& carding, what eating and drinking, what ba[n]queting and feasting is than vsed more than in all the yeere besydes? to the great dishonor of GOD, and impouerishing of the realme." 11

Even when presented under the sign of thrift, the spirit of Christmas threatens to undermine the household. It tends rapidly-as we see in the pairing of scrupulosity and excess in Freud, Žižek, Getrude, and Polonius-toward extremes. In the 1936 animated short "Christmas Comes but Once a Year," the narrative and its title song endorse a thriftiness about time itself: that the passing moment of the holiday should be seized and capitalized upon. The Depression-era fable of thrift presents itself as a lesson about adaptive household reuse: after a houseful of orphans is left crying when their threadbare Christmas presents fall apart, a jolly inventor passing by hears their cries and constructs new toys from everyday objects around the orphanage-vacuum cleaners, umbrellas, percolators. The story presents itself as an endorsement of thrift and ingenuity in the name of generosity, a potlatch fantasy in which nothing gets consumed and the joy of the gift is just a better kind of use. However, the benefactor's repurposing of household objects is in fact a depurposing: he exploits the occasion and matter at hand, but abuses the objects themselves. The Christmas miracle effectively empties the orphanage's storage closets and larder, in a transaction that turns profitable use into useless play and exchanges an army of round, weeping faces for smiling and singing ones. The profit is purely affective, which is-by most household economies-no profit at all. ${ }^{12}$

Even this cartoonishly excessive version of Christmas utility inherits a version of thrift energetically articulated in early modern England. As long as there have been ideologies of thrift, there have been anxieties about its excessive application. "Thrift" was a complex word in Shakespeare's lexicon (as it was for his contemporaries), serving at times as a synonym for profit (close to its cognate, "thriving") while also standing as a name for the methods to achieve such success. This latter-call it "methodological"-sense is closer to our own usage, denoting a set of techniques of scrimping and saving leading to the accumulation of personal capital. Andrew McRae has argued that this individualistic sense first emerged in the mid-sixteenth century, as the meaning of the word changed alongside the role of the individual householder in the English moral economy. ${ }^{13}$ Any emphasis on profit, however, was complicated by the traditionally ambiguous moral and social status of personal accumulation. Encouraged by biblical precedent, those who failed to redistribute their harvests had long been depicted as misers, starving the poor in favor of obsessive personal accumulation. As McRae and Lorna Hutson have both shown, several lines of 
argument in the sixteenth century reoriented this view, distancing "hoarders" of wealth and stuff from many of those negative associations. ${ }^{14}$ Craig Muldrew places Tusser's moralizing advice in the broader context of the early modern English moral economy, as conceptions of thrift were closely tied to the symbolic link between social and financial credit.In these arguments, the productivity of nature excuses the increase of husbandry and exempts it from charges of either usury or hoarding. Good husbands are simply making more, contributing to the common good rather than withholding from it. This resignification of "thrift" as profit is at work at several points, for instance, in The Merchant of Venice, where at stake in every use of the word is the question of when it is valid to make money grow. ${ }^{15}$ In Shylock's mouth, his "well-won thrift, / which he calls interest" (1.3.48-49) is always a contested term: as he defends himself in reference to the story of Jacob, "This was a way to thrive, and he was blest: / And thrift is blessing if men steal it not" (1.3.87-88).

The embattled position of hospitality in husbandry manuals of the sixteenth century often turns on the same tension within moral economy, pitting a neighborly impulse to spend against the basic imperative to save. In its instructions on how to thrive, Fitzherbert's Boke of Husbondrye (1523) warns readers against the slippery slope of unreasonable feasting, which begins with "loue \& charyte" but "endeth in pryde \& glotony," advising them to keep measure in all things, especially spending. Many sixteenth-century husbandry books end up having it both ways when it comes to giving and saving: to give (appropriately and on the correct occasion) will pay back with more profit. Fitzherbert called this principle the "sede of dyscrecyon": "For this sede of dyscrecyon hath a wonders property / for the more that it is take[n] of or lent of / the more it is. And therfore me semeth it sholde be more spyrytuall than temporall / wherin is a great dyuersyte / for a temporall thynge the more it is deuyded the lesse it is / and a spyrytuall thynge the more it is deuyded the more it is." ${ }^{16}$ As Bataille or Mauss might observe, this compensatory model does not really count as giving freely, even if the symbolic burden of eventual compensation is placed on providence rather than social obligation. Like social obligation, however, it operates according to a temporal delay: Fitzherbert's seed of discretion works like a wager or venture, betting on expenditure in the short term but counting on a restricted economy in future time.

Thomas Nashe's Summer's Last Will and Testament stages a conflict between miserly hoarding and wild prodigality among the seasons themselves. In Nashe's play, a character called Christmas is a radical miser and one of the sons of Winter, who enters with the motto Liberalitas liberitate perit. In this Christmas philosophy, liberality consumes itself. Summer, who is attempting to select a proper heir, objects to Christmas's excessive scrupulosity, complaining: "Why, thou should'st spend, thou should'st not care to get. Christmas is god of hospitality." ${ }^{17}$ Christmas responds, 
"So will he neuer be of good husbandry. I may say to you, there is many an old god, that is now growne out of fashion. So is the god of hospitality." Drawn conspicuously against type, Christmas is "a pinch-back, cutthroate churle, / That keepes no open house, as he should do, / Delighteth in no game or fellowship, / Loues no good deeds, and hateth talke, / But sitteth in a corner turning Crabbes, / Or coughing o're a warmed pot of Ale." 18 To Summer's outrage and confusion, Christmas refuses to enter singing a carol ("A merry Carroll would haue grac't thee well, / Thy ancestors haue vs'd it heretofore"), and disdains all feasting and hospitality. ${ }^{19}$ Nashe thus chooses to localize this conflict between generosity and scrupulosity-between good housekeeping and good hospitality-in the ironic rendering of Christmas, who believes the opposite of what he ought. In fact, as a reflection on the relationship between thrift, revelry, and inheritance-that is between dynastic time and seasonal time-Nashe's work offers a fascinating foil to the household philosophies of Hamlet and Tusser's Pointes. ${ }^{20}$ Like Hamlet, Nashe's play is a drama of inheritance, andlike Shakespeare's play-it turns on the possibility that an heir might be elected who disrupts the natural sequence of things. Like, Tusser's Pointes, it approaches this reflection on time and sequence through the seasons of the calendar year.

The irony of Nashe's miserly Christmas, however, is not quite so unprecedented: as Christmas says, the god of hospitality is grown out of fashion. Nashe's depiction of chilly Christmas specifically evokes contemporary complaints of decay in the holiday's observance, especially in the hospitality and generosity of aristocrats who traditionally opened their doors to locals for holiday celebration. Though there is some disagreement among scholars about the degree to which Christmas celebrations actually were curtailed in practice in the late sixteenth century, a range of subjects, issuing widespread complaints about the decay of hospitality, understood a new neglect of Christmas entertainment to mark a break with tradition on the part of those "that ancientlie did entertaine hospitalitie." ${ }^{21}$ As early modern subjects experienced what felt like an epochal break in the experience of Christmas and in the moral obligations of one social class to another, ancient hospitality seemed in the midst of being irrevocably lost.

Historians take this widespread anxiety about a "decline in hospitality" to be symptomatic of a transitional moment in the structure of English society and economy, as the social fibers of a moral economy seemed to come into conflict with a burgeoning profit economy. ${ }^{22}$ And, indeed, while some of this widespread anxiety about the decay of hospitality may reflect broader structural tensions at a transitional moment, Christmas nonetheless stood out for specific attack and took on particular symbolic value. Christmas had long been a time of "misrule": of social inversion, excess consumption, suspension of regular standards and social restraints. So-called Lords of Misrule were appointed on Christmas day to head up an alternative hierarchy, acting as temporary sovereigns of households or 
parishes. ${ }^{23}$ But, in the late sixteenth and early seventeenth centuries, Lords of Misrule in particular were frequently sermonized against and banned in many parishes. Christmas thus seemed not only to oppose but to invert and overturn the household law that "thrift" names, and much celebration of Christmas turned not just on expectations of generosity but on the specific suspension of hierarchy.

Holiday time thus promised a special license, as Christmas expenditure was tied to the performance of social inversion-a seasonal break with everyday life that seemed to shift household existence into the festive realm of play. Often, attacks against the prodigality and idolatry of Christmas took the specifically dramatic object of pageants, but the time of the holiday itself seemed performative and playful. A connection between Christmas reorderings and drama is recognized by Stubbes, who complains about "the other kinde of Playes, which you call Lordes of Misrule." 24 Tusser also uses the word "play" in proximity to the Christmas holiday, likewise signaling a shift in mode, or even a shift in rule. The seasons of life and of the year are "all quickly forgotten as a playe on a stage." And, in the final stanza of "Against Fantasticall Scruplenesse," Tusser asks his reader to "Play thou the good felow and harken to me, / hate none that be honest, though mery they be" (1570; sig. Diir $)$. In the first point of January, the reader is told to return to his regular role, to "go play the good husba[n]d, thy stock to renewe" (sig. Dii ${ }^{\mathrm{v}}$ ). Neither role, in Tusser's view, is more natural-both require practice, habit, and discipline-but both must be taken on and put off with the seasons. In either case, however, play is temporary, and depends on the liberty of movement between these different modes of being-albeit a liberty governed by the seasons themselves.

The possibility of reversing these roles-or moving between the time and space of play and not-play, or of holiday and thrift-could not be taken for granted. The main complaint of Nashe's Christmas against seasonal hospitality is that the temporary liberality of Christmas might be permanently destructive. Christmas refuses to entertain because seasonal hospitality would undo his house, literally undermining it:

Gluttony is a sinne, \& too many dunghils are infectious. A mans belly was not made for a poudring beefe tub: to feede the poore twelue dayes, $\&$ let them starue all the yeare after, would but stretch out the guts wider then they should be, \& so make famine a bigger den in their bellies, then he had before. I should kill an oxe, \& haue some such fellow as Milo to come and eate it vp at a mouth-full. Or like the Sybarites, do nothing all one yeare, but bid ghestes against the next yeare. The scraping of trenchers you thinke would put a man to no charges. It is not a hundreth pound a yeare would serue the scullions in dishclouts. My house stands vpon vaults, it will fall if it be ouerloden with a multitude. Besides, haue you neuer read of a city that was vnderminde and destroyed by Mowles? So, say I keepe hospitalitie, 
and a whole faire of beggers bid me to dinner euery day, what with making legges, when they thanke me at their going away, and setling their wallets handsomly on their backes, they would shake as many lice on the ground, as were able to vndermine my house, and vndoe me vtterly: It is their prayers would builde it againe, if it were ouerthrowne by this vermine, would it? I pray, who begun feasting, and gourmandize first, but Sardanapalus, Nero, Heliogabalus, Commodus, tyrants, whoremasters, vnthrifts? Some call them Emperours, but I respect no crownes, but crownes in the purse. Any man may weare a siluer crowne, that hath made a fray in Smithfield, \& lost but a peece of his braine pan. ${ }^{25}$

Christmas entertainment would dig under the foundations of the house(hold) like a mole, undermining both its conceptual and material architecture. Feasting is here the habit of emperors-not just sovereigns, but "unthrifts" who are poor governors of their own households. Though seasonal entertainment is defined by those boundaries, these limits are impossible to enforce, and threaten to turn all time into festival time.

\section{Christmas Time in Tusser's Pointes}

Thomas Tusser responds to this danger by giving seasonal hospitality an ambivalent place in his calendar, calling this festive section at the end of the year "A Digression to Hospitality." Tusser's A hundreth good pointes of husbandrie thus tries to navigate the periodic passage between hospitality and husbandry, theorizing along the way not just the management of superfluity but the strange place of holiday time in the annual calendar. The text is assembled according to the passage of time and remains entangled in it: the time of the seasons, the time of youth and old age, and the time of the rhyming points themselves, the rhythms of which pace the rhythms of the calendar in their progress from one month to the next. Their progression, however, is neither homogeneous nor undisturbed. In the first edition, of 1557 , one remarkable temporal disturbance goes under the name of "Christmas." Published by Richard Tottel in a slim quarto, the book begins with a brief dedicatory poem before turning to the four-line stanzas that comprise its century of instructive "points." These rhyming lines are organized according to the months of the year, beginning with August and moving sequentially through the harvest months, winter, and the rest of the year. There are only two interruptions to this movement through the calendar: between March and April, "A digression from husbandrie: to a point or two of huswifrie" (1557; sig. $\mathrm{Ci}^{\mathrm{V}}$ ); and, between December and January, four points on the subject and occasion of Christmas. Like the months that precede and follow it, Christmas gets its own pilcrow and series of numbered points. The holiday thus looks like a month in itself as well as an exception to that otherwise regular temporal progression. Slipped between December 
and January, a wrinkle in time at the turn of the year, it is both in and out of the calendar.

Christmas is not only strange because of its placement between the months, however. At multiple points, Tusser describes the annual rhythms of spending and saving as complementary. There is some tension, in this sense, between an annual cycle of saving and spending, and a longer, absolute course of increase. The points themselves follow this latter pattern in their enumerated accumulation through the volume. Indeed, both the text and the matter of the household are balanced between accumulation and dispersal, as husband and housewife must mediate between hospitality's open door and husbandry's closed storehouse.

In the editions of 1570 and 1573 , the rupture at Christmastime has been amplified. The edition of 1570 turns from the monthly progression of points to a cluster of longer poems by announcing "A digression" and enjoining the reader to "leaue husbandrie sleeping." In the 1573 volume, for which the titular number of points expands to 500, this festive section begins under the title of "A digression to hospitalitie," but is called in the table of contents, "A digression directing to hospitalitie," helping us see more clearly that the "to" of this alternate course is both spatial (hospitality is the destination) and commanding, delivering not just the text but the obedient reader to the proper seasonal decorum. Beginning with these editions, the yuletide suspension of the calendar's progress is accompanied by a break in the work's otherwise continuous formal composition. A small collection of poems follows, each appearing for the first time in the 1570 edition, a gathering that as a whole digresses from the compact and practical "points" preceding them, from the work's procession from month to month, and from the volume's repeated endorsement of storage, accumulation, and thrift. The poems emphasize the importance of giving to the poor and opening one's home during these often barren months, pairing these ethical instructions with reminders of the fragility of life and inevitability of death. (Winter is, Tusser reminds his reader, "a nipper of all thing in euery age.") At the same time, the efficiently instructive points of November and December have given over to something more like a verse miscellany. These short poems do not participate in the volume's general system of accounting, and make no contribution to rendering the debt of 100 or 500 points promised by Tusser's title page. The Christmastime poems, then, are presented not just as digression, but as surplus, a part of the book unkept by the bookkeeping to which the numbered points are subject.

In Tusser's formulation, Christmas hospitality thus digresses from the regular course of husbandry on multiple registers, each layered in the book itself and in the everyday labors of the household: literary form, calendrical form, and the form and content of household advice. These threads are already woven together in the collection as a whole, organized under the logic of what Tusser calls "thrift" to name a practice of prudent management that combines sensible spending (in our modern sense) with the vital 
proliferation we would now call thriving. This is hardly an original usage of the word, but it serves as a linchpin to the work as a whole, governing household matter and textual matter, the time of reading and the time of labor and provision. The goal, as Tusser explains in his "Ladder to Thrift," is "To make prouision thriftilie," and we ought to take this sense of provision precisely-an injunction to look forward, toward any future of dearth or cold or old age, and to gather accordingly. In the 1557 edition, a couplet concluding a sonnet on the properties of the months applies to the course of a year and to the course of a life: "So widsom bid kepe, and prouide while we may: / For age crepeth on as the time passeth away" $\left(\right.$ sig. $\left.\operatorname{Di}^{\mathrm{v}}\right)$. The practice of accumulation that Tusser's Pointes delineate and exhort entails this distinctive temporal orientation, a turning out of the present and toward future contingency. The time of thrift is always turned away from itself.

Throughout the calendar, the time of reading is keyed to the time of the year, and Tusser explicitly marks any suspension in this correspondence. In the only other nonmonthly section in the midst of the 1557 edition-titled, "A digression from husbandrie: / to a point or two of huswifrie"-Tusser steps out of the course of time: "Now here I think nedeful, a pawse for to make: / to treate of some paines, a good huswife must take" (sig. $\left.\mathrm{Ci}^{\mathrm{v}}\right)$. This pause transforms the time of the text and the object of its address, as Tusser turns explicitly to the housewife, whose labors here follow a different seasonal and textual rhythm. With this "pawse," Tusser asserts what we could call in narratological terms a disparity between the time of story and the time of discourse. ${ }^{26}$ In doing so, he reminds us of the keyed pacing between point and calendrical time that we had previously been following, but also affirms our ability to step out of it - an assertion that objectifies and naturalizes the time of the calendar by setting it against the husbandly perspective onto time. A similar kind of stepping aside is essential when we come to Tusser's digression at the end of December.

This general injunction to store for the future rather than spend in the present sits uneasily with the expenditures of Christmas. A time of pouring out instead of taking in, of spending before saving, the holiday exhorts husband and housewife to "be mery, and thanke god of all: / and feast thy pore neighbours, the great with the small." It is, as Tusser's poem reminds us, "an apt time to spend." The first of the 1557 Christmas points turns the poem's address to the housewife:

Get Iuye and hull, woman deck vp thyne house: and take this same brawne, for to seethe and to souse. Prouide vs good chere, for thou knowst the old guise: olde customes, that good be, let no man dispise. 
Tusser's embrace of "olde customes" defends traditional hospitality against the attacks of those like Stubbes but also against social transformations that drew the gentry out of the country and into the city for holidays, leading to complaints of the "destruction of ancient hospitalitie." ${ }^{27}$ Michael Bristol attributes the gift-governed logic of Tusser's Chrismastime to the force of the Nativity as a kind of "divine potlatch or lavish expenditure." 28 On one level, a suspension of the law of thrift places Christmastime under an alternate dispensation, closer to the temporary festive jurisdiction overseen according to custom by the lord of misrule. As closer attention to Tusser's text shows, the inversion of regular husbandry is awkwardly perched on the yearly calendar and in the makeup of the book. If good husbandry promises to instruct in good household rule (specifically through the compilation of individual rules), it is not clear what the effect of possible misrule-or the suspension of rule in general-might be on either the form or content of Tusser's advice. ${ }^{29}$

Tusser is clear that the time of Christmas can only ever be exceptional. January begins by marking this shift back into everyday husbandry: "When Christmas is done, kepe not Christmas time still: / be mindefull of rering, and loth for to kill” (1557; sig. Bii $\left.{ }^{\mathrm{V}}\right)$. The break is firm. Christmas thus incites both a dilation and a caesura in the calendar, a time outside of time that overturns the moral economies and rhythms of nonfestive husbandry. As the lines that follow confirm, with this move out of the holiday, the mode of the Pointes has switched back from expenditure to increase: "For then what thou rerist, thou nede not to dout: / will double thy gaine, ere the yere come about"(1557; sig. Biiv-Biiir $\left.{ }^{\mathrm{r}}\right)$. With festive killing complete, the household can return to its habits of growth, the different arrangements of life and death that govern the rest of the calendar year. The Pointes paints husbandry according to a logic of (lively) capital and material accumulation-a turn that at once economizes the natural world and naturalizes and rationalizes the pursuit of profit. Ventriloquizing husbandry, Tusser claims at one point that "The earth is my storehouse, the sea my fisheponde: / What they haue to pleasure with, is in my hand" (1570; fo. $\left.2^{\mathrm{v}}\right)$.

Meanwhile, as was implicit in Tusser's Pointes and poems on the holiday and would have been explicit in household practices, consumption operated by way of death. To be hospitable was to take the life of animals that might otherwise have continued to be "reared." Like uprooting or nipping in the bud, it represents an absolute loss. In this version of housekeeping, the senses of "thrift" and "thrive" are still very close together, at times almost indistinct. Husbandly thrift enables the stuff of the household to thrive:

Be gredy to spende all, and careles to saue: and shortly be nedy, and redy to craue.

Be wilfull to kill, and vnskilfull to store: and sone giue vp houskeping longe any more. 
In these four lines, killing and spending are paralleled, and "store" names not just the stockpiling of stuff but the kind of stock that proliferates by skillful cultivation. The husbandman is not an owner of inert matter but a custodian of the miscellaneous beings that comprise the household and its environs. His future orientation, keyed to their thriving, is in this sense collaborative and communal. The untimeliness of hospitality, on the other hand, is underwritten by bloodletting.

In her study of medieval illustrated calendars, Bridget Ann Henisch has found that it is only in winter scenes that the preparation and consumption of meals is depicted-particularly, in December, with attention given to the slaughter of livestock and the display of their parts. The contrast is reflected in the conclusion to a fifteenth-century rhyme: "At Martnesmasse I kylle my swyne; / And at Cristesmasse I drynke redde wine." ${ }^{30}$ Christmas is the time of consumption, not production. And in this sense feasts are functional, an occasion to work through what has been culled and cannot be stored. However restrained by custom and decorum, Christmas entertainment does operate according to the fiction of free expenditure. As becomes especially clear in the emphasis on eating meat in the winter holidays, hospitality operates by consumption, and might easily tilt into willful and wild destruction. ${ }^{31}$

Because of Tusser's distinctive understanding of the nature and function of his book, these parallel transformations in calendar and economy are accompanied by a seasonal disruption of literary form. Throughout the various editions, Tusser makes increasingly clear that the points themselves are meant to participate in the logic of husbandry, counted among the res parvae that the husbandman busily amasses. ${ }^{32}$ The "Digression" that appears in the 1570 edition also inaugurates a formal transformation. The poems that follow are organized in longer groups of stanzas and given titles printed in italic that sit above the denser blackletter verse below. We have wandered out of Tusser's prudent precepts and into the realm of something more like a lyric miscellany, as if the Pointes have turned for the holidays from their regular progression of couplets to another genre entirely - one that formally plays out the principles of generosity and hospitality espoused in the poems themselves (including "A description of apt time to spend" and "Against fantasticall scruplenesse").

The short poems that appear in this section have several remarkable affinities with the most influential lyric miscellany of this period, the Songes and Sonettes first published, like the first edition of Tusser's Pointes, by Richard Tottel in 1557. By the time Tusser's 1570 edition had appeared, Tottel had brought out at least six editions of his miscellany. The poems in this section echo Tottel's Miscellany both typographically and generically, displaying the verse itself in blackletter and the summary titles in an airier roman or italic font above, some of them with pilcrows. The titles-nearly all of them "A description of ..."-also seem directly inspired by the patterns of titling in Tottel's Miscellany. Compare the layout of the pages between Songes and Sonettes (Figure 2.1) and the 1570 Pointes (Figure 2.2), noting the visual shift that begins with the "digression." 

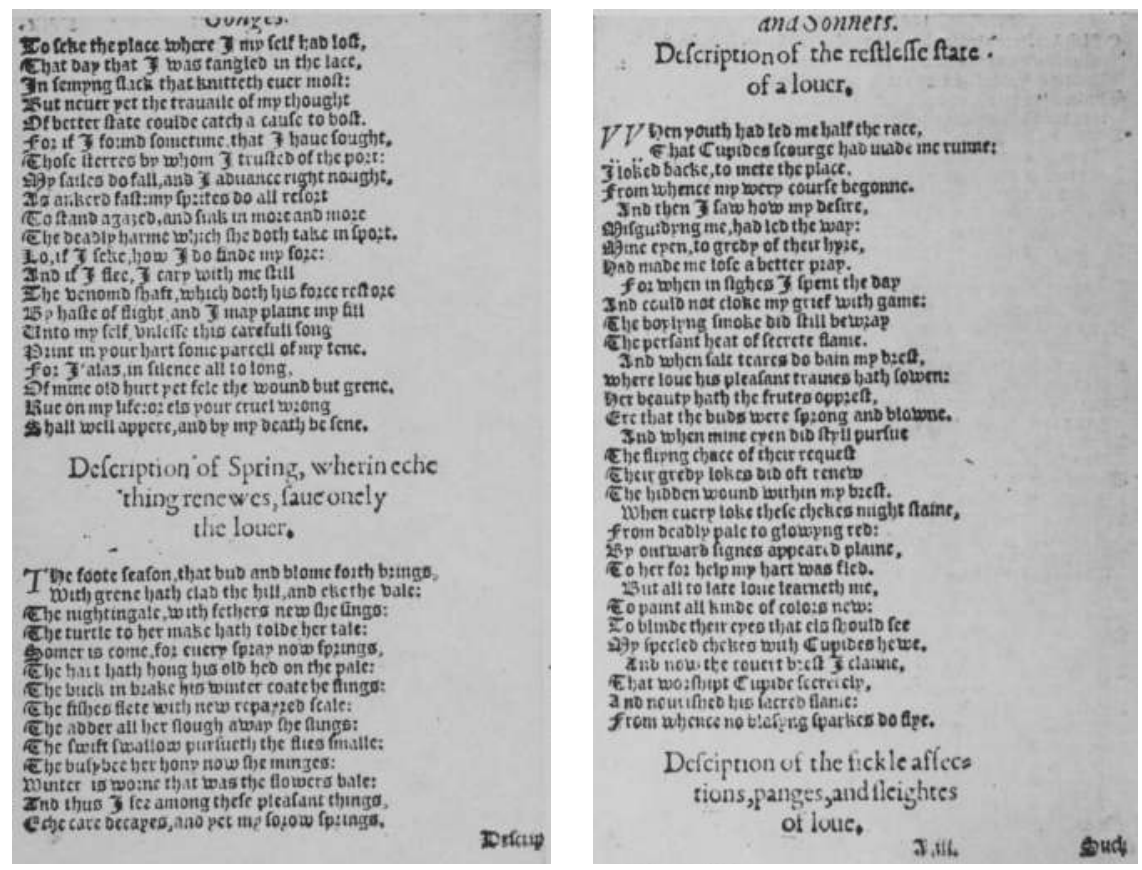

Figure 2.1 Songes and sonettes, written by the right honorable Lorde Henry

Haward late Earle of Surrey, and other (London: Richard Tottel, 1557), sig. Aii ${ }^{\mathrm{v}}-\mathrm{Aiii}^{\mathrm{r}}$.

In his preface to the first issue of the Songes and Sonettes in 1557, Tottel associates the publication of poetry with a moral economy of expenditure and circulation, echoing popular complaints about Christmas in his accusations against inhospitable noble hoarders. In publishing poems previously limited to private manuscript circulation, he describes himself as obeying an ethical imperative of redistribution, a charitable impulse that he puts forth within a national frame: "It resteth now (gentle reader) that thou think it not euyll done, to publishe, to the honor of the Englishe tong, and for profite of the studious of English eloquence, those workes which the vngentle horders vp of such treasure, haue heretofore enuied thee." ${ }^{33}$ For too long, he suggests, manuscript poetry had been circulated only in the hands of a few, locked up in the inhospitable spaces of the court. Tottel thus presents himself both as learned improver of the commonwealth and as a kind of Robin Hood figure, who has just broken vernacular poetry from the jail of aristocratic courtly circuits. ${ }^{34}$ His purpose, then, is altruism and magnanimity: the book itself is presented as a hospitable space. With this attack on hoarding as ungentle, Tottel makes us ask what counts as the good husbanding of poems.

This social and economic logic is intensified when the miscellaneous poems appear at Christmastime, as they first do in the 1570 editions of the Pointes with these titles: "A description of time and the yere," "A description of lyfe 


\begin{tabular}{|c|}
\hline 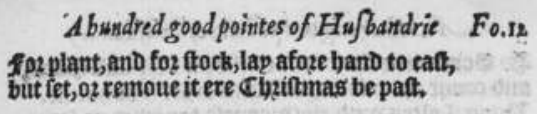 \\
\hline 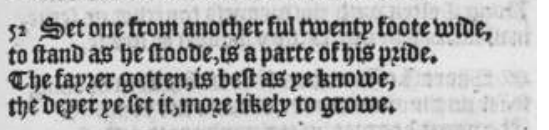 \\
\hline 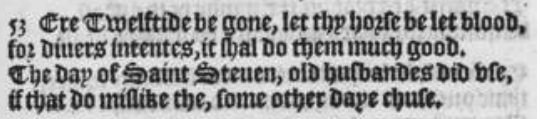 \\
\hline$A$ digreßion \\
\hline 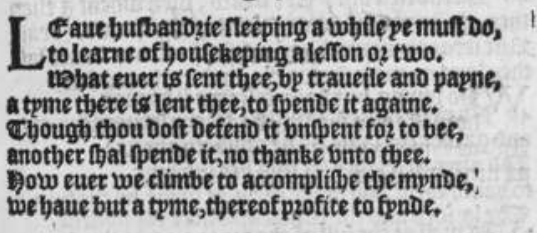 \\
\hline $\begin{array}{c}\text { Adefcription of time } \\
\text { and the pere. }\end{array}$ \\
\hline 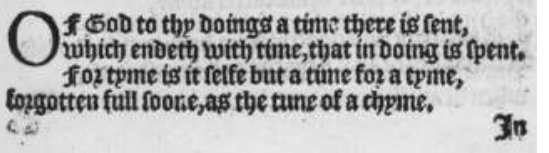 \\
\hline
\end{tabular}

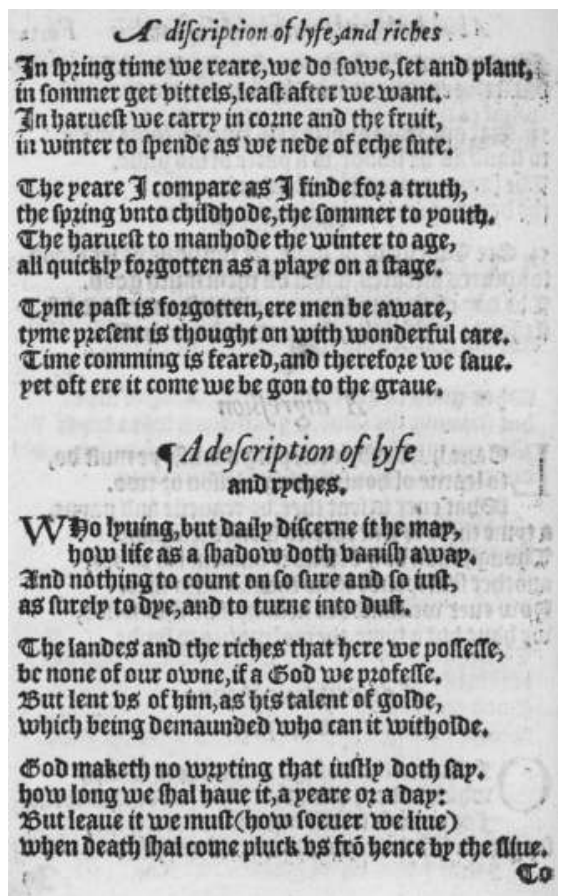

Figure 2.2 Thomas Tusser, A hundreth good pointes of Husbandry, lately maried vnto a Hundreth good poynts of Huswifery (London: Richard Tottel, 1570), fo. $12 \mathrm{r}-\mathrm{v}$.

and ryches," "A description of house kepyng," "A description of Christmas," "A description of apt time to spend," "Against fantasticall scruplenesse," and "Christmas husbandly fare." In this, they again closely echo Tottel's Miscellany, the first four poems of which are likewise titled "Descriptions" of one kind or another, as are another dozen or so throughout the collection. This is one reason to think that this section has been reorganized by Tottel himself, who is now thought by many to be the editor of the Songes and Sonettes and, specifically, the source of the poems' titles. ${ }^{35}$

Within the temporal pause that this digression represents-while husbandry is still, at this moment, sleeping — these "descriptions" enact a prodigal performance of dilation. Introduced under the sign of digression and filling out the time of Christmas, the writing down that "description" names is also a writing off and a writing out - a performance of copiousness, in other words, that confirms the "apt time" to linguistically spend and resists "fantastical [lexical] scruplenesse" (a charge that might easily be levied against the rest of Tusser's collection. $)^{36}$ These poems are not sequentially sutured to a natural course of time like the monthly points that precede and follow them; indeed, unhooked from such a sequence, they unbind the reader from that determinate correlation, giving the (aspiring or just prurient) husbandman a vantage on the passage of time that is not bound by that 
temporal movement. The digression withdraws from the calendar only to capture it symbolically. The exceptional time of Christmas expenditure, then, is also the strange time and space of literary proliferation. The lyrical and formal license that accompanies this logic of exception in fact performs a powerful version of the misrule that Stubbes and others feared, rewriting household jurisdiction from a position liminally outside of it, replacing it not with misrule but with the better jurisdiction of description.

\section{Preserving Digression: Shakespeare's Spendthrift Sighs}

In describing Hamlet's excessive mourning, Claudius also admonishes the Prince for having perverted a most natural sequence. By extending what should merely be a "term" of obsequious sorrow, Hamlet displays not grief, but a "simple and unschooled" understanding of it. Claudius reminds Hamlet that mourning (obsequies) follow a natural sequence and term, much like a genealogical sequence of fathers:

'Tis sweet and commendable in your nature, Hamlet, To give these mourning duties to your father, But you must know your father lost a father, That father lost, lost his - and the survivor bound

In filial obligation for some term

To do obsequious sorrow. But to persever

In obstinate condolement is a course

Of impious stubbornness, 'tis unmanly grief, It shows a will most incorrect to heaven, A heart unfortified, a mind impatient, An understanding simple and unschool'd.

The solution, Claudius proposes, is for Hamlet to "throw to earth / This unprevailing woe, and" - and this is the rub- "think of us / As of a father." To exchange fathers, in Claudius's mind, is not only necessary, but pious, manly, correct, fortified, and patient. Hamlet's obsession with grief refuses Claudius's proposed indifference to the particulars; "Why seems it so particular with thee," Gertrude inquires of her son's grief (1.2.75).

Patricia Parker has connected Hamlet's comment on his mother's remarriage- "Thrift, thrift, Horatio"— to other examples of the play's obsession with sequence, its almost compulsive return to "preposterous" moments of sequential disruption or reordering. ${ }^{37}$ For all of Hamlet's obsession with "obsequies" and mourning, the play is overrun with the "maimed rites" (5.1.12) of terrible and abrupt burials. ${ }^{38}$ The violent insult of "thrift" in this case registers a deep untimeliness, a rupture in natural order vividly embodied in Hamlet's description of cold, leftover flesh. Hamlet, to Claudius (as Gertrude, to Hamlet), suffers from a case of bad timing that fails to fulfill the expectations of his gender. Appropriate mourning — in its unthrifty mode-thus seems 
untimely in the specific sense that it resists being bound by the finite "term" that shapes Claudius's restricted temporal economy. Offering advice to Laertes after the death of his father, Claudius reiterates this emphasis on time:

Not that I think you did not love your father,

But that I know love is begun by time,

And that I see, in passages of proof,

Time qualifies the spark and fire of it.

There lives within the very flame of love

A kind of wick or snuff that will abate it;

And nothing is at a like goodness still,

For goodness, growing to a pleurisy,

Dies in his own too-much.

(4.7.109-117)

The stoppage of time that mourning represents quickly turns to excess: it "dies in its own too-much." A technique of temporal management, prudence can never simply stay still. Claudius depicts the stillness of a temporal digression-like Hamlet's mourning —as a deadly pathology.

Claudius continues his advice to Laertes by inverting Hamlet's language of thrift, calling excessive mourning a kind of reckless expenditure and inaction:

That we would do,

We should do when we would; for this 'would' changes

And hath abatements and delays as many

As there are tongues, are hands, are accidents,

And then this 'should' is like a spendthrift sigh

That hurts by easing.

A close kin to this spendthrift sigh, Hamlet's grief is exorbitantly unprofitable, poured out in the excesses of his speech, useless and-as a kind of matter-without substance. ${ }^{39}$ Claudius's "spendthrift sighs" offer one example of a frequent use in Shakespeare's works of negative cognates of "thrift" to refer to linguistic events. All of these unthrifty attempts at language or expression fall flat or pour out fruitlessly; they are what J. L. Austin would call "infelicitous" speech acts, in these cases not just ineffective but actively wasteful. Claudius' phrase is closely echoed by Viola in Twelfth Night, who also wonders what fruit her performance might bear:

What will become of this? As I am man,

My state is desperate for my master's love;

As I am woman,- - now alas the day! -

What thriftless sighs shall poor Olivia breathe! 
The image of leaky passion likewise effeminizes Hamlet, suggesting with the word "sigh" that we should group his ritual insistence with other cases of (erotic) misrecognition. A spendthrift throws his or her affective energies at an improper object. Shakespeare's Sonnets likewise connect material and temporal prodigality to a problem of language- - here, the work of the poems themselves. Throughout those early in the sequence, the poet worries repeatedly about the young man's unthriftiness - not just his vanity or prodigality in the sense that Helgerson describes the phenomenon of "Elizabethan Prodigals," but in the precise sense of his failure to produce an heir, to bear fruit. ${ }^{40}$ As the poet asks in Sonnet 4, "Unthrifty loveliness, why dost thou spend / Upon thyself thy beauty's legacy?”(1.1-2). What might seem a static fault-his failure to produce-is in fact a kind of consumption. Sonnet 2 frames this imperative of use within the time of the agricultural calendar: in forty winters, will he have prepared prudently for the cold of old age? Poor thrift would leave him unprepared for winter: "Then being ask'd where all thy beauty lies, / Where all the treasure of thy lusty days, / To say, within thine own deep-sunken eyes, / Were an all-eating shame and thriftless praise" (1.5-8). This praise is thriftless specifically because it fails to produce a son: only the beloved can do that, by procreating. This waste is a kind of hoarding: unsoundly storing treasure deep within himself, rather than opening it to future use. Like Tottel's hoarders-up of manuscripts, short-sighed and anti-social, there is something ungentle in this picture. Inhospitably, the beloved is not keeping his house (in the genealogical sense) warm for winter: "This were to be new made when thou art old, / And see thy blood warm when thou feel'st it cold" (1.13-14).

The young man is thus unthrifty in a sense we have seen several times over: he fails to extend a sequence. Like Claudius's Hamlet, he "dies in his own too-much." It also returns us to the misogynist logic behind the remark from Hamlet with which we began: with its instrumentalization of household intimacy, Hamlet's language of thrift miniaturizes, domesticates, and feminizes the political force of Gertrude's remarriage, eliding his own investment in a guaranteed succession. In its early modern articulations, discourses of household thrift were inseparable from the rhyming pair in which the term often appeared-"wiving and thriving." The real and symbolic burden of balancing thrift and hospitality was often women's work, and, as Lorna Hutson has argued, the resignification of thrift and profit in early modern England turned on a rhetorical strategy that symbolically deployed women to displace this responsibility. ${ }^{41}$ Reduced to the maxim offered in A Godlie Form of Household Gouernment (1612): "The dutie of the husband is, to be a giver: and of the Wife, to be a saver." ${ }^{42}$ In Sonnet 2 (as throughout the first part of the sequence), the work of women in thrift and household maintenance is elided in favor of a masculine fantasy of increase-of fathers and sons and fathers ad infinitum. Hamlet's vitriol toward his mother hones in precisely on her disruption of this fantasy; but from another angle, one that Hamlet cannot abide, her "thrift" is a rational strategy of household management. It serves-instead of a direct line of descent-herself and the household. 
Once again, a language of thrift emerges with urgency at moments where a natural sequence is threatened. But why should every digression represent a fatal disruption? As we have seen in Tusser and Nashe, digressions from sequence may not be disruptive at all. Tusser's interruption of the sequential calendar is not preposterous; it does not disrupt or overturn the natural order. Instead, his seasonal digression elegantly manipulates the passage of textual time, while the digressive poems affirm the fixity of temporal sequence from a point outside of it. The holiday digression does not disorder the household, nor does it merely offer the kind of social safety valve that critics and historians have often attributed to carnival. Instead, it gathers and sequesters the potentially disordering license of festival time within the orderly aesthetic license of a miniature verse miscellany. By moving out of the time of the calendar toward something that looks like literature, Tusser's digression renders stable the object of the calendar itself. His digression from sequence feeds and fixes sequence by using the codes of holiday hospitality to enframe an abstract reflection on time and its passage. Crucially, however, the stability of both modes is contingent on the terms of transfer between them-a spatial language of movement or transport that Tusser frequently uses to describe mediation between textual modes and between hospitable orientations. These metaphors of movement are essential: Tusser manages conflicting times of hospitality by turning them figuratively into spaces, literary topoi with doors to be open or shut, and through which the husbandman might travel as both host and surveyor. His "digression" accords in this sense with the general spatial strategy of provision, which fixes the fleeting passage of time in the table of a calendar-a tropological domestication that preserves the expenditures of both time and of hospitality in the space of digression.

But there is something more to the resonances we hear between Tusser's Pointes, Hamlet, and Sonnet 2. Echoing Claudius and Viola, the image of "thriftless praise" in Sonnet 2 has several senses that connect expenditure and waste to the stuff of linguistic utterance. More than a description of the beloved's thriftlessness, the image captures something about the project of the Sonnets in general: an anxiety that the efforts of poetic praise (like a "spendthrift sigh") might not come to fruition. Lyric composition itself (again, like Christmas) enacts expenditure and loss. As Thomas Greene suggests in his reading of husbandry in the Sonnets, "To compose poetry is expensive, just as loving is expensive." ${ }^{43}$ More expansively, Georges Bataille writes that poetry is synonymous with unproductive expenditure, as a name for "the least degraded and least intellectualized forms of the expression of a state of loss." ${ }^{44}$ Barbara Correll has very suggestively argued we consider the mixing of erotic and economic registers in Renaissance poetry in the context of Bataille's conception of a general economy, of "squandering without reciprocity." 45 The common poetic language of debt, value, and currency is not merely metaphorical, she argues. Rather than borrowing from the separate sphere of a restricted economy, poetry participates in an economy, toothough one of expenditure and loss and not scarcity and accumulation. 
By drawing on deep and longstanding tensions between hospitality and thrift, Tusser's Pointes (with Tottel's other poetic publications) lay the groundwork for an analogous view, inscribing an attachment to expenditure in the visual form of the printed text. Lyric language-both volumes, in their various editions, seem to say-should not be understood according to a restricted economy of scarcity. According to this picture, poetry, love, loss, and Christmas hospitality all operate by pouring out rather than gathering in. These are ventures that rarely pay off-and should not, perhaps, be undertaken with hope of compensation.

Thrift and the possibility of its breach have haunted both the materiality of household practice and the material of poetic language in the texts I have considered in this essay. This relationship, however, is not strictly a homology between kinds of efficiency, or between parallel economies, symbolic and real. As Bataille writes, as a rarified form of unproductive expenditure, poetic expense may "[cease] to be symbolic in its consequences," as it becomes a kind of sacrifice-for the poet, a real and not symbolic loss. ${ }^{46}$ With his poetic publications, Richard Tottel seems to agree, echoing the defenders of traditional Christmas hospitality in a refusal of "excessive scrupulosity." In Tottel's redistributive fantasy, the promise of the printing press thus looks something like Bataille's image of the sun as a force that "gives without ever receiving," the naturalistic core from which his conception of surplus was generated. Of course, Tottel is selling these books, and it is unlikely that this optimistic picture of textual hospitality is in reality a fantasy of loss and expenditure. ${ }^{47}$ As we saw with Tusser's Pointes, these expenditures of form and time are always enframed-literally, bound.

But it is significant that this is the language in which a nascent literary sphere is delineated in this moment-that is, as a kind of effusive (and always potentially self-destructive) hospitality. As Derrida writes, an act of hospitality can "only ever be poetic." The examples I have considered in this essay help us see an unexpected richness in Derrida's choice of the word "poetic" to denote these strange effects of hospitality. His use of the word, I would suggest, is in fact made possible by the specific history we glimpse in Tusser and in Shakespeare. "Poetic" here indexes the genealogy of a literary culture and social formation in which poetry comes to name a certain effect of openness and generosity-one that was fundamentally in formation at this moment in early modern literary culture. As Tusser, Tottel, and Shakespeare have shown us, however, we would do well to register the inverse of Derrida's equation: an act of poetry in these works can only be legible as such if it is already an act of hospitality.

\section{Notes}

This essay is deeply indebted to the conversations begun in our 2013 Shakespeare Association of America (SAA) seminar on "Shakespeare and Hospitality." I am grateful to all of the participants and to groups at the University of Southern California and the Huntington Library who read this work and provided invaluable suggestions. For their close engagement, I would especially like to thank the editors of this 
volume as well as Dympna Callaghan, Margreta de Grazia, Heather James, Rebecca Lemon, Carla Mazzio, and Marjorie Rubright. Images included are by permission of the Huntington Library, San Marino, California.

1. William Shakespeare, Hamlet, ed. Harold Jenkins, The Arden Shakespeare, second series (London: Methuen, 1982). Further references to the play are to this edition and are noted parenthetically in the text.

2. Ritual, Lacan goes on, has a special relationship to mourning, as it rewrites the particularity of loss under the absolute sign of symbolic lack. We might keep this difficult quality of ritual value in mind as we think through the openness of hospitality and the problems of memory both in Hamlet and in husbandry, remembering that ritual, as Hamlet insists here, cannot take on quantitative value as other kinds of value can, potentially stunting a totalizing system of exchange. Jacques Lacan, "Desire and the Interpretation of Desire in Hamlet," trans. James Hulbert, in Yale French Studies 55/56 (1977), 11-52; 40.

3. Slavoj Žižek, Did Somebody Say Totalitarianism?: Five Interventions in the (Mis)Use of a Notion (New York: Verso, 2001), 39. As Žižek writes, "What, then, is the status of thrift as a vice? In an Aristotelian frame of mind, it would be simple to locate thrift at the opposite extreme from prodigality, and then, of course, to construct some middle term-prudence, the art of moderate expenditure, avoiding both extremes-as the true virtue. The paradox of the Miser, however, is that he makes an excess out of moderation itself" (41).

4. In this sense, these readings offer another example of how later readers have retrospectively placed Hamlet ahead of his time, a phenomenon Margreta de Grazia has identified and unknotted in Hamlet without Hamlet (Cambridge: Cambridge University Press, 2007), especially 7-22 and 23-44. In this case of "Thrift, thrift, Horatio," the prince's readers take his insights to be as much economic as psychological.

5. Freud, Jokes and Their Relation to the Unconscious, trans. James Strachey (New York: W.W. Norton, 1960), 47.

6. G. R. Hibbard, in his annotation to this line, notes that "Hamlet, the Renaissance Prince, has nothing but scorn for this middle-class virtue so much prized by Shylock" (Hibbard, ed., Hamlet [Oxford: Clarendon Press, 1987], 165). R. S. White has suggested that Gertrude's famous "enseamed bed" might also refer to an image of household thrift, namely, the practice of repairing old sheets by cutting them down the middle and resewing the edges together, to place new fabric at the worn center. White's reading of this line as capturing a kind of thrifty "doubling" closely fits the doubleness of thrift I have argued here is at work in Hamlet's accusation. I am grateful to Dympna Callaghan for this citation. R. S. White, "Ophelia's Sisters," in The Impact of Feminism in English Renaissance Studies, Dympna Callaghan, ed. (New York: Palgrave MacMillan, 2007), 93-113.

7. Because hospitality must be offered graciously, "graciously offered beyond debt and economy, offered to the other, a hospitality invented for the singularity of the new arrival, of the unexpected visitor," Derrida writes that the law of unlimited hospitality becomes an exception to law as such: "This unconditional law of hospitality, if such a thing is thinkable, would then be a law without imperative, without order and without duty. A law without law, in short." Jacques Derrida, with Anne Dufourmentelle, Of Hospitality, trans. Rachel Bowlby (Stanford, CA: Stanford University Press, 2000), 83.

8. When Marcellus compares the uncanniness of the first scene to the strange temporality of a cock's crow on Christmas- "The bird of dawning singeth all night 
long: / And then, they say, no spirit dares stir abroad"-Horatio does not seem fully persuaded, responding, "So I have heard, and do in part believe it." Though it is not possible to go into more depth here, much more could be said about the relationship between Hamlet and Christmas. Alvin Kernan believes that Hamlet was performed on the day after Christmas at Hampton Court, before James and Anne. (Marcellus' words about Christmas, he writes, "would have struck the right holiday tone.") Alvin Kernan, Shakespeare, the King's Playwright: Theater in the Stuart Court, 1603-1613 (New Haven: Yale University Press, 1995), 31. Anselm Haverkamp draws more philosophical implications from the possibility that the play took on some of the allegorical features of a court masque, and takes its possible performance at this particular holiday as a "provocation" ("The Ghost of History: Hamlet and the Politics of Paternity," Law and Literature 18, no. 2 [2006], 171-97; 189-90). On this opening scene and temporality of the play in general, see Richard Wilson, "When the Cock Crew: The Imminence of Hamlet," Shakespeare 3, no. 1 (2007), 1-17. On the winter seasonality of Hamlet, see also Catherine Belsey, "Shakespeare's Sad Tale for Winter: Hamlet and the Tradition of Fireside Ghost Stories," Shakespeare Quarterly 61, no. 1 (2010), 1-27.

9. Derrida, Of Hospitality, 2.

10. Thomas Tusser, A bundreth good pointes of husbandry lately maried vnto a hundreth good poynts of huswifery: newly corrected and amplified with dyuers proper lessons for housholders, as by the table at the latter ende, more plainly may appeare (London: Richard Tottel, 1570), sig. $\mathrm{Bi}^{\mathrm{r}}$. Subsequent references to the Pointes will appear in text, with reference to the edition date and signature.

11. Philip Stubbes, The Anatomie of Abuses (London: Richard Jones, 1583), sig. O8 ${ }^{\mathrm{r}}$.

12. King Lear can also profitably be read in light of the seasonal affiliations of expenditure in early modern England. The play was advertised as having been performed on St. Stephen's Day, the day after Christmas and a time traditionally for giving to the poor, as in King Wenceslas's famous wassailing. Lear may in this context be seen as a fable on expenditure and destructive redistribution. Taking Lear as "Shakespeare's meditation on a zero-sum economy," Richard Halpern argues that the play imagines a response to a crisis of consumption among the aristocracy (The Poetics of Primitive Accumulation [Ithaca: Cornell University Press, 1991], 215-70). More recently, Brian Sheerin has read "nothing" in the play as a political reflection on expenditure, using Bataille to find in it a version of sovereignty without ontology (Brian Sheerin, "Making Use of Nothing: The Sovereignties of King Lear," Studies in Philology 11, no. 4 [2013], 789-811). On Lear and hospitable expenditure in relation to household practices and debates, see Elton, "King Lear" and the Gods (Lexington: University Press of Kentucky, 1988), 287-98; and Heather Dubrow, Shakespeare and Domestic Loss: Forms of Deprivation, Mourning, and Recuperation (Cambridge: Cambridge University Press, 1999), 104-18.

13. McRae, God Speed the Plow: The Representation of Agrarian England, 1500-1660 (Cambridge: Cambridge University Press, 1996), 142-51. See also Peggy Knapp, Time-Bound Words (New York: Palgrave, 2000).

14. McRae, God Speed the Plow, 73-75; Lorna Hutson, The Usurer's Daughter: Male Friendship and Fictions of Women in Sixteenth-Century England (New York: Routledge, 1994), chap. 1, esp. 22-30. In his treatment of the meanings of thrift specifically in the context of Tusser's work, Craig Muldrew places the husbandman's moralizing advice in the broader context of the early modern English moral economy, as conceptions of thrift were closely tied to the symbolic link 
between social and financial credit (The Economy of Obligation: The Culture of Credit and Social Relations in Early Modern England [New York: Palgrave Macmillan, 1998], 161-7).

15. See Scott Cutler Shershow on Shylock's economy and especially the relationship of usury to the parable of the talents ("Shakespeare Beyond Shakespeare," in Marxist Shakespeares, ed. Jean Howard and Scott Cutler Shershow [New York: Routledge, 2001], 245-64). Shershow's identification of an ideology of generosity at the heart of conceptions of Shakespeare's universality, defenses of capitalism, and in The Merchant of Venice helps deepen the connections we are able to see between thrift and thriving. On the relation of the play's language of thrift to erotic expenditure, see Lars Engle, “Thrift is Blessing': Exchange and Explanation In The Merchant of Venice," Shakespeare Quarterly 37, no. 1 (1986), 20-37. Peggy Knapp explores the range of senses of "thrift" employed in The Merchant of Venice in Time-Bound Words, 168-9.

16. John Fitzherbert, Here begynneth a newe tracte or treatyse moost profitable for all husbandemen (London, 1530), sig. C3r. See also Walter De Henley, The booke of thrift, containing a perfite order, and right methode to profite lands, and other things belonging to husbandry. Newly Englished, and set out by I.B. gentleman of Caen in France (London: John Wolfe, 1589): "You ought to know foure things, in layings out and in expenses: the first is, What yee must giue, how $\&$ to whom, and how much you must giue: for the first, that you must give before need requires it: for two shillings giuen then, are better accou[n]ted of then then twelue shillings, when neede forceth you to it: for the second, whether you ought to giue, or to spend, and to doe it willingly, then the same shall bee double rewarded vnto you, and if you do giue vnwillingly, you shall leese all that you doe either giue or lay out: for the thirde, giue to him that may be profitable vnto you \& to others: for the fourth, how much you must giue, neither more nor lesse, but according as the worke is, either great, or litle, that you haue to do: looke on the poore, not for the praises of the worlde, but for to haue the loue of God, which giueth vs all things. You shall enlarge your lands and tenements by your loyal men sworn" (fo. $13^{\mathrm{r}}$ ). On these and other early modern husbandry books, see G. E. Fussell, The Old English Farming Books: from Fitzherbert to Tull, 1523 to 1730 (London: C. Lockwood, 1947.).

17. On the connection that Nashe's play draws between household economy and the festive excess of ritual time, see Lorna Hutson, Thomas Nashe in Context (Oxford: Oxford University Press, 1989), 155-71; and C. L. Barber, Shakespeare's Festive Comedy (Princeton, NJ: Princeton University Press, 1959), 58-79.

18. Thomas Nashe, A pleasant comedie, called Summers last will and testament (London: Walter Burre, 1600), sig. G4 ${ }^{\mathrm{r}}$.

19. The association of Christmas with song on which Nashe's allegory draws here provides a suggestive context for its association with poetry in Tusser's Pointes, discussed later. On carols, see Christopher Marsh, Music and Society in Early Modern England (Cambridge: Cambridge University Press, 2010), 195-7. Marsh also notes that already in the early sixteenth century the most single-sheet printed carols were sold in December.

20. In a clarifying reading of the play, Marie Axton argues that Summer's Last Will is an argument about revelry in general, showing the significance of the lack of song accompanying Nashe's wintry characters. Axton, "Summer's Last Will and Testament: Revel's End," in The Reign of Elizabeth I: Court and Culture in the Last Decade, ed. John Guy (Cambridge: Cambridge University Press, 1995), 
258-73. Daryl Palmer sees the "noisy orality" of Nashe's entertainments playing out a more general literary strategy of hospitality, especially through the work of puns (Hospitable Performances: Dramatic Genre and Cultural Practices in Early Modern England [West Lafayette, IN: Purdue University Press, 1992], 134-5). The character closest to the concerns and imagery of husbandry discourses is Harvest, who directly echoes Tusser in saying "I keep good hospitality for hens and geese." Though they agree on Harvest's connection of language and hospitality, Palmer and Hutson take different positions on the significance of that connection. For Palmer, "Harvest seems to suggest that an excess of language (the Nashian problem) will enable a parallel reallocation of language and material resources, thus fulfilling the requirements of hospitality" (147); while Hutson, on Harvest's language, finds that "in breaking up separate formulations it refuses to ensure provision of memorable meaning for future use by the reader" (Thomas Nashe, 123).

21. Felicity Heal notes that these Christmas celebrations were in fact carefully organized: "In general the image of the noble Christmas which emerges from the accounts is one of licensed openness, of the breach of conventions which obtained in the giving of hospitality for most of the year, though not entirely of genial anarchy, since a careful structure was imposed upon this display of aristocratic largesse" (Hospitality in Early Modern England [Oxford: Clarendon Press, 1990], 77). Phebe Jensen argues that traditional Christmas hospitality mostly survives the Reformation: "In England, Christmas continued to be celebrated robustly after the reign of Henry VIII, and traditional Christmas hospitality was practiced by Protestants throughout this period. At royal courts, great houses, and rural parishes, Christmas in the late sixteenth and early seventeenth centuries was marked with traditional pastimes such as wassailing, pageantry and games, plays, dicing, carding, dancing, singing, present exchanges on New Year's Day, and, above all, feasting, with roasts, mince pies, and plum puddings prominently featured" (“'Honest mirth \& merriment': Christmas and Catholicism in Early Modern England," in Redrawing the Map of Early Modern English Catholicism, ed. Lowell Gallagher [Toronto: University of Toronto Press, 2012], 215). On transformations of seasonal ritual in early modern England, see Eamon Duffy, The Stripping of the Altars: Traditional Religion in England 1400-1580 (New Haven: Yale University Press, 1992), 11-52; and Ronald Hutton, The Rise and Fall of Merry England (Oxford: Oxford University Press, 1994).

22. See Heal, Hospitality. In an article on the 1596 campaign for general hospitality, Steve Hindle richly examines the responses to dearth and to a perceived decline in charity through a focus on a series of orders issued by the privy council in Christmas of that year. Tracing the symbolic and material "thresholds of hospitality" through local, parish responses to these orders, Hindle shows how "the fact that general hospitality did not become a legal obligation arguably only increased the moral pressure on yeoman and husbandmen to throw open their doors" ("Dearth, Fasting, and Alms: The Campaign for General Hospitality in Late Elizabethan England," Past \& Present 172 [2001], 47). On narratives of decline, see also Keith Wrightson, "The 'Decline of Neighborliness' Revisited," in Local Identities in Late Medieval and Early Modern England, ed. Norman L. Jones and Daniel Woolf (Basingstoke: Palgrave, 2007), 19-49. Michael Bristol finds that, as the traditional redistribution performed by the nobility declined, new, popular forms of redistribution took their place ("In Search of the Bear: Spatiotemporal Form and the Heterogeneity of Economies in The Winter's Tale," Shakespeare Quarterly 42, no. 2 [1991], 85). 
23. Polydore Vergil, for example, sees the origin of these "christenmas lordes" in the role of servants in Roman Saturnalia. For an overview of the development of these rituals and symbols of misrule, see Hutton, The Rise and Fall of Merry England, 9-10, 54-55; and Hutton, The Stations of the Sun: A History of the Ritual Year in Britain (Oxford: Oxford University Press, 1996), chaps. 1-10.

24. Stubbes, Anatomie; cited in Barber, Shakespeare's Festive Comedy, 27.

25. Nashe, Summer's Last Will, sig. $\mathrm{H} 2^{\mathrm{r}-\mathrm{v}}$.

26. Ultimately, the dualism that sustains this ostensible double-talk is never quite stable. In the sense, we might keep in mind Barbara Herrnstein Smith's critique of the dualism grounding Chatman's division between these two faces of narrative. Smith questions "whether either of these temporal disparities-or both of them taken together-requires us to posit the existence of two distinct, independent time orders for every narrative or, conversely, whether they can be understood in terms that do not already assume a dual-leveled model of narrative structure" ("Narrative Versions, Narrative Theories," Critical Inquiry 7, no. 1 [1980], 224).

27. Muld sacke, or the apologie of hic mulier (London, 1620), sig. C1 ${ }^{\mathrm{r}}$. Cited in Michael Bristol, Carnival and Theatre: Plebian Culture and the Structure of Authority in Renaissance England (New York: Routledge, 1985).

28. Bristol, "In Search of the Bear," 158.

29. It is interesting in this regard that Stubbes's language for the transgressions of Christmas frame them as a parody of the political order: The cause of Christmas "fooleries" like dice-playing, mumming, and vast overconsumption, he wrote, is, "they think they haue a commission and prerogatiue that time, to do what they lust, and to folow what vanitie they will. But (alas) do they thinke that they are priuiledged at that tyme, to doo euill?" (sig. O $7^{\mathrm{v}}$ ).

30. Bridget Ann Henisch, The Medieval Calendar Year (University Park, PA: Pennsylvania State University Press, 1999), 30; 7.

31. We could consider this in light of Raymond Williams's observation (following a distinction made by Rosa Luxembourg) that imperatives of hospitality in early modern England manifested a charity of consumption rather than production, "which when applied to working societies was inevitably a mystification" (The Country and the City [Oxford: Oxford University Press, 1973], 30-32).

32. I explore Tusser's miniaturized rhetoric and the temporality of his verse forms at greater length in "The Point of the Couplet: Shakespeare's Sonnets and Tusser's A hundreth good pointes of husbandrie," ELH 83.1 (2016), 1-41. In a prefatory poem, first appearing in the 1570 edition, Tusser or his editor prescribes the keeping of points like the storing of grain: "Then kepe them in memorie fast, / From youth, to the last of thy lyfe" $\left(\mathrm{Aii}^{\mathrm{r}}\right)$. Asking, "Vvhat looke ye for more in my booke?" he offers "Things nedefull in tyme for to come." The points themselves, in other words, are meant to be kept as provisions-held fast in memory or inscribed on walls or vessels. On small forms in Renaissance verse and rhetoric, see Rosalie Colie, "Small forms: multum in parvo," in The Resources of Kind: Genre-Theory in the Renaissance (Berkeley: University of California Press, 1973), 32-75; and Mary Thomas Crane, Framing Authority: Sayings, Self, and Society in SixteenthCentury England (Princeton, NJ: Princeton University Press, 1993).

33. Songes and sonettes written by the right honorable Lorde Henry Haward late Earle of Surrey, and other (London: Richard Tottel, 1557), "To the reder."

34. On the significance of Tottel's making-public of these poems, see Arthur Marotti, Manuscript, Print, and the English Renaissance Lyric (Ithaca, NY: Cornell University Press, 1995, 212-28, 293-302). Harold Love argues that the 
more closed coterie circulation of which Tottel complains nonetheless represents a form of limited "scribal publication" (Scribal Publication in Early Modern England [Oxford: Clarendon Press, 1993]). His emphasis on the redistribution of property also suggests we place Tottel in the orbit of the various allusions to Robin Hood that Jenny Mann traces in Outlaw Rhetoric in Renaissance handbooks of rhetoric and poetry, participating in a broader debate on the legitimate and illegitimate reuse and redistribution of language (Outlaw Rhetoric: Figuring Vernacular Eloquence in Shakespeare's England [Ithaca, NY: Cornell University Press, 2012], 1-28).

35. Steven May convincingly rules out the most likely other possibilities, and enriches our sense of Tottel as a literary editor, in "Popularizing Courtly Poetry: Tottel's Miscellany and Its Progeny," in The Oxford Handbook of Tudor Literature, 1485-1603, ed. Mike Pincombe and Cathy Shrank (Oxford: Oxford University Press, 2009), 420-2.

36. Morality is not out of the picture. A digression also suggests a transgression and the reminder that we "leave husbandry sleeping" suggests this digression might result in some kind of bed trick. Lucrece for example complains of the vileness of her "digression" (1.248).

37. Patricia Parker, Shakespeare from the Margins: Language, Culture, Context (Chicago: University of Chicago Press, 1996), 45-48.

38. My reading of sequence and its consequences in what follows is indebted to Margreta de Grazia's insight that the play is obsessed not with Hamlet's subjectivity but with property and with the problems that ensue when its transmission is knocked off course. In this sense, "thrift" as Hamlet uses it is another (however partial) name for the ungrounding or deracinating of property from land in which some of Hamlet's most influential readers (especially Hegel and Marx) are so interested and to which they attribute an epochal historical shift-as de Grazia writes, "the onset of that period is marked in each case by a ground-breaking event of an almost literal kind" (Hamlet without Hamlet, 25).

39. Quentin Skinner takes "spendthrift" as an example of a linguistic tactic, by which moralists tried "to coin new and unfavorable evaulative-descriptive terms, and apply them to describe familiar forms of social behavior which one may have come to wish to see condemned. This happened in the case of the ideology I have been citing with the concept of squandering and of being a spendthrift. Both these terms became widely used for the first time at the end of the sixteenth century in order to describe and express a new disapproval of the aristocratic ideal of conspicuous consumption." "Errant" and "exorbitant," Skinner notes, also took on their current metaphorical/evaluative uses in the early seventeenth century. "Some Problems in the Analysis of Political Thought and Action," Political Theory 2, no. 3 (1974), 277-303; 285.

40. Richard Helgerson, The Elizabethan Prodigals (Berkeley: University of California Press, 1976).

41. As she writes, "the division is not one of labour, but of ethical accountability in an economy of representation.... One of the things Xenophon and his sixteenth-century imitators understood by 'husbandry' was a handy signifying system, which enabled the strategic ennobling of practices of uncertain ethical validity, while displacing, through sexual difference, fears about their consequences" (The Usurer's Daughter, 50-51). We could also profitably read both Tusser's huswife and Gertrude's thrift in light of Wendy Wall's project to resignify domesticity and unearth forms of agency and power at work in domestic spaces in Staging Domesticity: Household Work 
and English Identity in Early Modern Drama (Cambridge: Cambridge University Press, 2002), 9; on Tusser, see 35-36.

42. Robert Cleaver, A godlie forme of householde gouernment (London: For Thomas Man, 1598), 171. On the role of women in overseeing and keeping in order household property, see Wendy Wall, "Forgetting and Keeping: Jane Shore and the English Domestication of History," Renaissance Drama 27 (1998), 123-56; and Natasha Korda, “Judicious oeillades': supervising marital property in The Merry Wives of Windsor," in Marxist Shakespeares, ed. Jean Howard and Scott Cutler Shershow (London: Routledge, 2001), 82-103.

43. Thomas Greene, "Pitiful Thrivers: Failed Husbandry in the Sonnets," in Shakespeare and the Question of Theory, ed. Patricia A. Parker and Geoffrey Hartman (New York: Methuen, 1985), 241. Greene goes on to conclude that neither expense is truly recuperable. Barbara Correll argues, however, that Greene ultimately does not endorse the more radical version of poetic expenditure found in Bataille, but instead cashes out this picture of loss in the form of aesthetic profit, such that "artistic achievement outweighs, [and] ultimately contains the anxiety it provokes" (Correll, "Terms of "Indearment": Lyric and General Economy in Shakespeare and Donne," ELH 75, no. 2 [2008], 241-62; 247).

44. Georges Bataille, “The Notion of Expenditure," in Visions of Excess: Selected Writings, 1927-39 (Minneapolis: University of Minnesota Press, 1985), 116-29; 120.

45. Correll, “Terms of Indearment," 241-62.

46. Bataille, "The Notion of Expenditure," 120. Bataille here follows a division that he has drawn of artistic productions into two kinds of expenditure: real (such as architecture, music, dance) and symbolic (especially literature and theatre, though expenditures of the first kind may be over layered with these kinds of "external significations"). Bataille writes that this sense of poetry can only be applied in rare cases, however, and in those cases the kind of expenditure swings away from the symbolic and back to the real: "for the rare human beings who have this element at their disposal, poetic expenditure ceases to be symbolic in its consequences; thus, to a certain extent, the function of representation engages the very life of the one who assumes it."

47. The turn in the final part of this essay to the relation of general hospitality to literary culture deserves much further consideration, and my suggestions here are indebted to the work of Scott Cutler Shershow, especially "Shakespeare Beyond Shakespeare" and The Work and the Gift (Chicago: University of Chicago Press, 2005). The utopianism of Tottel's redistributive project in the sense we see earlier accords less with the arguments of Mauss or Bataille, but more specifically with Lewis Hyde's argument about the gift in relationship to the work of art. We might therefore keep in mind Shershow's caveat about Hyde's connection of Bataille's sense of expenditure to the aesthetic. On the connections between literary and economic discourses, Shershow writes: "these particular homologies reveal the traces of that broad historical process by which the esthetic, construed as a kind of 'gift' - a value absolutely distinguished from mere economic value-would as such become a crucial underpinning of a system otherwise insisting on the 'restricted' economic values of thrift, calculation, and self-interest. In other words, the idea of a universal esthetic seals itself off from 'economic' considerations, but only so as to allow the latter free reign everywhere else. As Bourdieu has memorably expressed it, 'art for art's sake' is just another way of saying 'business is business"” ("Shakespeare beyond Shakespeare," 248-9). For Shershow's reading of Hyde, see The Work and the Gift, 139-40. 


\title{
3 "Here's Strange Alteration!" Hospitality, Sovereignty, and Political Discord in Coriolanus
}

\author{
Thomas P. Anderson
}

In Coriolanus, Shakespeare rewrites early modern friendship theory, associating it with a concept of hospitality that turns friendship's emphasis on concord and amity into political liabilities. Depicting friendship as a form of hospitality, Shakespeare instead conceives the constitution of friendship as a political event that affirms antagonism and discord as irreducible dimensions of early seventeenth-century alternative political thought. In act 4, when Coriolanus arrives in Antium looking for Aufidius, the play stages the union between the two enemies as an event that embodies conventional friendship theory estranged by the force of hospitality that informs it. Coriolanus arrives in Antium seeking hospitality, calling his enemy's home a "goodly city" (4.4.1), and the Citizen tells Coriolanus that Aufidius "feasts the nobles of the state" (4.4.8) as he directs him to his enemy's "house" (4.4.10). The language between Coriolanus and the Citizen establishes Antium as a place of conviviality, inviting even to its enemy who has "made thy widows" (4.4.2) and made "[m]any an heir ... groan and drop" even before battle (4.4.2-4). Greeting his enemy with open arms, Aufidius implores the Roman warrior to

Oh, come, go in, And take our friendly senators by th' hands Who now are here, taking their leaves of me, Who am prepared against your territories, Though not Rome itself.

Aufidius describes his hospitality as "most absolute" (4.5.135), while seeming to qualify it with the condition that Coriolanus turn his desire for revenge against Rome. After welcoming him into his home, he asks Coriolanus to "set down / ... thine own ways, / Whether to knock against the gates of Rome, / Or rudely visit them in parts remote, / To fright them ere destroy" (4.5.137-142). In limiting absolute hospitality at the moment that he offers it to Coriolanus, Aufidius demonstrates the impossibility of an authentic welcome-one that is absolute and unfettered by the force of its own conditional demands that transgress it. Jacques Derrida comments on the force of transgression immanent in hospitality itself, noting that "[i]t is as though hospitality were the impossible: as though the law of hospitality defined this very impossibility, 
as if it were only possible to transgress it, as though the law of absolute, unconditional, hyperbolical hospitality, as though the categorical imperative of hospitality commanded that we transgress all the laws ... of hospitality." ${ }^{2}$ The play's qualifying language at the moment of the welcome announces the limits of hospitality. Aufidius directs Coriolanus to other guests in his house who will "[s]ay yea to thy desires" (4.5.149), and offers him "[a] thousand welcomes!" (144). At the same time that he opens his house to his enemy and he tells his rival that he is now "more a friend than e'er an enemy" (154), he hedges, as if to qualify the new friendship: "Yet, Martius, that was much" (146). Aufidius's "yet" qualifies the event of friendship forged in this moment of intimate hospitality, measuring its value against what it might get Aufidius in return, and underscores its fleeting condition as a political force.

With the scene of intimate hospitality between Coriolanus and Aufidius serving as this essay's focus, I argue that Shakespeare links early modern hospitality to a concept of friendship fraught with division and violence. Putting into question the dialectic of virtue espoused in classical models of sovereign amity, this association between violence and friendship underscores hospitality's political potential. ${ }^{3}$ In reconfiguring classical notions of friendship common during the early modern period, Shakespeare makes the case that sovereign absolutism is, in fact, nourished by a form of hospitality predicated on friendship characterized by consensus and fraternity. More specifically, the play's representation of a politics of friendship redistributes the force of sovereign absolutism by disrupting community in favor of the force of division and discord. According to this reading of Shakespeare's political philosophy, a form of political antagonism explored in Coriolanus through the contours of personal and political friendships is the basis for an eventful politics outside of the scope of early modern absolutist and republican models. In Coriolanus, to know one's friend is at the same time to know one's enemy-or, more precisely in relation to the depiction of hospitality at the center of this chapter, to welcome one's friend at the same time is to welcome an enemy. Hinted in the rhetoric of hospitality characterizing the two warriors' union is a concept of friendship that upsets the formation of community and exposes the limits of consensual politics that in Shakespeare's political philosophy erases necessary and constitutive antagonisms at the core of civic communities.

\section{Friends Fast Forsworn}

"Oh, come, go in" (4.5.130), invites Aufidius in act 4, in an instance of hospitality that calls attention to the threshold that demarcates the guest and host, the enemy and the friend. In Of Hospitality, Derrida explores the erosion of this threshold in moments of absolute hospitality, the kind that Aufidius appears to extend to his rival:

"Enter quickly." Quickly, in other words, without delay and without waiting ... the stranger, here the awaited guest, is not only someone to 
whom you say "come," but "enter," enter without waiting, make a pause in our home without waiting, hurry up and come in, "come inside," "come within me," not only toward me, but within me: occupy me, take place in me, which means, by the same token, also take my place. ${ }^{4}$

Hospitality in Derrida's account is depicted as an occupation, a surrogation that twines host and guest. At the threshold of the house, Coriolanus and Aufidius are transformed; the inviting host, as Derrida observes, "becomes the hostage. ... The guest becomes the host's host." ${ }^{5}$ For Derrida, as for Shakespeare in this moment of hospitality and friendship, the "substitutions make everyone into everyone's hostage." ${ }^{6}$ In Coriolanus, the threshold between guest and host structuring hospitality is obscured by the aporetic logic of substitution informed by the force of friendship that transforms enemies into friends.

Elsewhere, Derrida considers the surrogatory logic of political friendship, speculating on the potential meaning of Montaigne's use of Aristotle's declaration: "O my friends, there is no friend." ${ }^{7}$ For Derrida, this "impossible declaration" (1) seems irreconcilable, "unjoinable" (1). Elaborating on the contradiction in the force of friendship expressed in Aristotle's declaration, Derrida focuses on the declaration's capacity to include opposing elements within the same syntactical structure: "In two times but at the same time, in the contretemps of the same sentence" (1). Derrida suggests that Aristotle's declaration of friendship paradoxically "states the death of friendship" (27), which is, for Derrida, the "locus of the problem-the political problem of friendship" (27). In a politics of friendship that structures the scene of absolute hospitality, the friend and the enemy "ceaselessly change places" (72): "Hence, every time, a concept bears the phantom of the other. The enemy the friend, the friend the enemy" (72). The rhetoric of friendship in Coriolanus, which dramatizes Aristotle's paradox, offers a critique of sovereignty that redistributes the contours and consequences of absolutism to other, putatively more democratic political formations. His depiction of friendship in the play, especially of the hospitality that Aufidius shows Coriolanus in act 4, where the Roman warrior is described as "more a friend than e'er an enemy" (4.5.145), challenges the culturally and politically dominant concept of friendship informed by philosophers such as Aristotle and Cicero and outlined most recently by Laurie Shannon in Sovereign Amity. Shannon argues that "friends, flatterers, counselors, monarchs, tyrants and their minions, and the tales of consent and counsel they enact all join to embody a mythography of the political institution before liberalism." ${ }^{8}$ According to Shannon, Renaissance writers "stress the making of a consensual social bond or body that is not inherently subordinating." 9 Specifically, discourses of friendship in the sixteenth century "invariably link the mirroring of selves with this making of (quasi-civic) bodies." 10 This aspect of doubling common in the rhetoric of early modern friendship allegorizes an "instance of political formation, and it finds repeated valorization in the texts of Renaissance 
self-fashioning." ${ }^{11}$ In drawing our attention to the period's rediscovery of classical friendship theory, Shannon also shows us how early modern writers conceptualized the bonds of friendship as sovereign - that is, both salubrious and consensually hierarchical. In effect, sovereign amity, as Shannon points out, describes dual sovereigns consenting to a social form of parity. She writes, "Instead of expressing dissent as such, friendship models configure an image of political consent, offering a counterpoint to prevailing types of polity. These political valences are central to 'sovereign' friendship's rhetorical, affective, and political dispensations." ${ }^{12}$ The intimacy of early modern sovereign amity, as Shannon shows, stresses parity and consent within friendship as viable political forces. Shakespeare's Roman play shows, however, that while there can be no form of democracy without the hospitality of friends- "without the calculation of majorities, without identifiable, stabilizable, representable subjects all equal" as friends ${ }^{13}$ - these democratic forms must also respect the "irreducible singularity" that in Coriolanus is immanent in the political economy of friendship. ${ }^{14}$

Entering Aufidius's house in act 4 after being banished from his beloved Rome, Coriolanus wagers that he brings more value to Aufidius alive than he brings to him dead. Antium, Aufidius's city that Coriolanus once imagined as an apocalyptic site "to oppose his hatred fully" (3.1.20), is now invitingly hospitable, a "goodly city" (4.1.1), and the Roman warrior surprisingly announces that his "love's upon/ This enemy town" (4.4.23-24). Indeed act 4, scenes 4 and 5, in which Coriolanus and Aufidius forge an alliance against Rome, are remarkable precisely because of the shift from the militaristic, antagonistic tone that characterizes much of the play. Upon entering his sworn enemy's house, Coriolanus's vocative exclamation announces this shift: "O world, thy slippery turns!" (4.4.12). The "slippery turns" that Coriolanus goes on to describe involve both friendship and hospitality, specifically turning a sacred friend into an enemy and turning an avowed enemy into a friend:

Friends now fast forsworn,

Whose double bosoms seems to wear one heart,

Whose hours, whose bed, whose meal and exercise

Are still together; who twin, as 'twere, in love

Unseparable, shall within this hour,

On a dissension of a doit, break out

To bitterest enmity.

The hero's description of his former relationship with Rome is rich with the rhetoric of friendship common in the early modern period. The use of phrases such as "double bosoms," "one heart," "still together," "twin," and "unseparable" to describe the nature of the bond of friendship that conjoins him to Rome seems to have been taken directly from descriptions of amicitia perfecta from writers whose work Shannon explores in Sovereign Amity, 
including John Tiptoft, Michel de Montaigne, Thomas Elyot, and Nicholas Grimald. As Shannon shows, as early as 1481 Tiptoft emphasized the similitude that characterizes ideal friendship, translating Cicero's famous description of a friend as "another ... same" and suggesting of friends that "of those tweyne he shold make wel nygh one." ${ }^{15}$ Half a century later, Elyot writes that ideal "frendshippe" is "a blessed and stable connexion of sondrie willes, makinge of two persones one in hauinge and suffringe ... properly named of Philosphers the other I. For that in them is but one mynde and one possession."16 Employing similar tropes of friendship, Nicholas Grimald makes amity the subject of a poem that appears in Tottel's Miscellany. In "Of Frendship," he writes, "Behold thy frend, and of thy self the pattern fee: / One soull, a wonder shall it seem, in bodies twain to bee." 17

Other Renaissance humanists translate treatises into English that have friendship as their central theme. Nicholas Udall's translation of Erasmus's Apophthegmes describes the famous relationship between Alexander and Haphestion according to the proverb "amicus alter ipse ... two frendes are one soul and one body." " Shannon has pointed out that the error in Udall's translation is no mistake: "The errors here ... substituting 'one' body for 'two bodies,' make no mistake: two equal corporeal bodies bound in friendship constitute a single corporate or juridical body, a legal fiction creating an operative unity." 19 Montaigne makes a similar observation in his essay "Of Friendship": "In the friendship I speak of, our souls blend and melt so entirely, that there is no more sign of the seam which joins them. If I am pressed to say why I loved him, I feel that I can only express myself by answering, because it was he, because it was I." ${ }^{20}$ Montaigne goes on to contemplate the "fusion of ... wills" in an ideal friendship and concludes, "Everything actually being in common between them ... and their relationship being that of one soul in two bodies, according to Aristotle's very apt definition." ${ }^{21}$ Montaigne's ideal friendship has "no other model than itself, and can be compared only with itself." 22

For these early modern writers, the bonds of ideal friendship appear unbreakable and irreplaceable; for Coriolanus, however, untwining his bond with Rome means also replacing one friendship with another and counting on the hospitality of his enemy:

Unseparable, shall within this hour, On a dissension of a doit, break out To bitterest enmity. So, fellest foes, Whose passions and whose plots have broke their sleep To take the one the other, by some chance, Some trick not worth an egg, shall now grow dear friends And interjoin their issues. So with me.

My birthplace hate I, and my love's upon

This enemy town. 
Coriolanus's rapid transfer of affection from Rome to Antium-“[o]n a dissension of a doit" and "by some chance"-seems to counter the bonds of true friendship, which are, according to Elyot, "confederated" and "issuing ... out of the one body, and entringe in to the other." ${ }^{23}$ Using Coriolanus as an exemplum for failed friendship, Cicero warns that "alliances of wicked men not only should not be protected by a plea of friendship, but rather they should be visited with summary punishment of the severest kind, so that no one may think it permissible to follow even a friend when waging war against his country." 24 Yet, Coriolanus's relationship with Rome suggests that he seems at least to view friendship as the core tenet of his political philosophy, more valuable than any doit-a worthless coin that Coriolanus says eventually pays for his break from his Roman fraternity.

\section{Hostages for Rome}

As the vehicle for Shakespeare to explore the force of dissensus in politics shaped by a form of absolute hospitality, the rhetoric of friendship in Coriolanus appears in both public and private settings. The play imbricates friendship and politics in its first scene, in which Menenius hears grievances from Rome's hungry citizens. First Citizen describes Caius Martius as "chief enemy to the people" (1.1.6-7), and the friend-enemy distinction is reinforced when Menenius confronts the crowd. He calls the citizens, "my good friends, mine honest neighbors" (1.1.55-56). Four more times before Caius Martius arrives, Menenius addresses either the group of citizens or an individual citizen as "friends" $(1.1 .58,121,132)$ or "friend" $(1.1 .118)$. His rhetorical attempt to quell the anger of the citizens notwithstanding, his use of the rhetoric of friendship in his address to the hungry mob frames the scene and suggests its role in the political dynamics of the play. Martius's disdain for the citizens in this scene and throughout the play, I suggest, is his blunt rejection of comity and an extension of his insistence on an alternative form of a politics of friendship foundational to the Roman state.

The citizens' position as "great toe" (1.1.146) of the Roman assembly describes their inferior position relative to other Roman statesmen and turns their supplication into a plea for conditional hospitality. In the fable of the belly, Menenius becomes a host, comparing the senators to "the good belly" (139) nourishing the citizens, who, as his guests, are "mutinous members" (140), nerves, veins, and appendages of the body. Calling the citizens his "incorporate friends" (120), Menenius as host or "storehouse" (126) administers food, delivering to the citizens their "natural competency / Whereby they live" (130-131). The very structure of power explored in this scene militates against a politics of friendship informed by similitude, confederation, and union. ${ }^{25}$ Friendship implies parity and symmetry, "through rational desire and free choice rather than hierarchy, physicality, and self-loss or self-dilution." ${ }^{26}$ Indeed, Martius's rejection of the citizens in act 1 , scene 1 , along with his refusal of their desires throughout 
the play, is a rejection of Roman republicanism figured as conditional hospitality. Coriolanus's insults—he calls the citizens "curs" (1.1.159), "dissentious rogues" (155), "scabs" (156), and "fragments" (212)—are motivated by an implicit challenge to the political dependency that structures Roman politics in the play.

If, as I am suggesting, we view Coriolanus's rejection of the citizens, along with his refusal finally to participate in Roman political custom later in the play, as a commitment to a form of friendship emerging in the space of failed republicanism, the play offers an affirmative politics imagined in the portrayal of the intimate hospitality between Aufidius and Coriolanus in act 4 . Yet the alliance forged between the two bitter enemies destabilizes hospitality as a political force at the same time that it suggests its liberating potential. ${ }^{27}$ More precisely, the hospitality at the core of Coriolanus's new relationship with Aufidius in act 4 radically reconceptualizes the logic of friendship common in the early modern period, suggesting that the play disrupts the communitarian space imagined in the classical rhetoric of friendship. In its wake, the play glimpses an irreducible, albeit unsustainable, anti-community that rejects consensus.

My focus on the constitutive condition of friendship's failure, informed by the absolute hospitality in the scene, as a sustainable force that shapes political sovereignty follows rich lines of inquiry offered most recently by Graham Hammill and Julia Reinhard Lupton. In her reading of Marlowe's The Jew of Malta, Lupton emphasizes the erosion of "prepolitical fellowship" into a notion of community formed by uncivil politics, ${ }^{28}$ and Hammill argues that Marlowe's depiction of betrayal becomes his "response to ... the sovereign bond." ${ }^{29}$ Hammill elaborates on the productive nature of betrayal reflected in early modern literature in terms of the formation of political alternatives to sovereign absolutism: "instead of positing a public space based on national identity, [English writers] imagined a far more fractured and fragile sense of community based on temporary political affiliations, divided between friend and enemy, and threatened by the tyrannical inclinations of sovereign power-both real and imaginary." ${ }^{30}$ At the core of the relationship between Aufidius and Coriolanus is the force of hospitality that precludes rapprochement and establishes rejected friendship as the critical force against Roman state absolutism. ${ }^{31}$

The treatment of Martius by an inhospitable Rome after his victory at Corioles expresses the political power of the concept of friendship in the play. Brutus acknowledges Coriolanus's banishment in language that relies on the friend-enemy distinction: "There is no more to be said, but he is banished / As enemy to the people and his country" (3.3.114-115). Rejoicing over his banishment, other witnesses to Coriolanus's punishment echo Brutus's language. An Aedile says, "The people's enemy is gone, is gone!" and the others on stage shout, "Our enemy is banished! He is gone!" (3.3.133-134). Indeed, even before his banishment, the custom of showing his wounds to the citizens and wearing the gown of humility is depicted as a ritual of 
friendship. The Fourth Citizen, speaking for the common people, says to Coriolanus: "You have been a scourge to [Rome's] enemies; you have been a rod to her friends. You have not loved the common people" (2.3.85-87). The Fifth Citizen follows, "We hope to find you our friend, and therefore give you our voices heartily" (2.3.97-98). As Coriolanus asks the citizens for their voices to make him consul, the citizens express their response in terms of friendship. Seventh Citizen says, "Therefore let him be consul. The gods give him joy, and make him good friend to the people!" (2.3.126-127). In an effort to save Coriolanus's consulship, Volumnia compares honor and policy to "unsevered friends" (3.2.42) that in war "grow together" (3.2.43) and encourages her son to maintain the friendship between honor and policy in peace, where "each of them by th' other lose / That they combine not there" (3.2.44-45). And in language that foreshadows Coriolanus's alliance with Aufidius in act 4, she says, "I know thou hadst rather / Follow thine enemy in a fiery gulf / Than flatter him in a bower" (3.2.90-92).

The language of comity that structures the scene between Coriolanus and the citizens, as he struggles to ask for their voices, establishes friendship as a force in support of absolutism even as the politics of friendship seem to enfranchise citizens, giving them a voice in the republic. ${ }^{32}$ In an acknowledgement of the paradox of their enfranchisement, Third Citizen says, "We have power in ourselves to do it, but it is a power that we have no power to do. For if he show us his wounds and tell us his deeds, we are to put our tongues into those wounds and speak for them. So, if he tell us his noble deeds, we must also tell him our noble acceptance of them" (2.3.4-9). The emptiness of the ritual, I suggest, hints also at the emptiness of hospitality that sustains Roman absolutism with friendship that makes Coriolanus hostage to Rome. The Third Citizen identifies a type of friendship predicated on telling and speaking-vividly imagined as putting a tongue in Coriolanus's wounds. In the play's extended association of the coming political community and the rhetoric of friendship throughout acts 2 and 3 , the citizens' voices depict a form of communicative sociability necessary to sustain political friendship and by extension civic enfranchisement, a drive to expand the economy of friendship to include more friends in the communitas. Coriolanus's rejection of this mode of friendship suggests his refusal to obscure the dissent at friendship's core with the glib discourse of inclusion, unanimity, and agreement.

At the end of act 3, Brutus banishes Coriolanus after describing him as "enemy to the people of his country" (3.3.115). Coriolanus responds by reversing the terms of his exclusion:

You common cry of curs, whose breath I hate

As reek o' th' rotten fens, whose loves I prize

As the dead carcasses of unburied men

That do corrupt my air, I banish you! 
Coming immediately after Roman tribunes banish him-"It shall be so! it shall be so! Let him away! / He is banished, and it shall be so!" (3.3.102-104)— Coriolanus's decree reversing banishment and exiling the city complicates the logic of rejection at stake in the play. James Kuzner associates this moment of rejection with the trope of the gay outlaw or the sodomite, whose very vulnerability inaugurates and sustains his tenuous but potent political viability. ${ }^{33}$ Coriolanus's "[v]agabond exile" (3.3.86), in which he turns his back on the city in search of "a world elsewhere" (132), is precisely the moment that the reject assumes a force preventing him from becoming a static figure vitiated of a politically agonistic potential. The play's reversal of the logic of exile exposes the fantasy of comity and accord in the exclamation from the Aedile and other citizens who witnessed the scene:

AEDILE: The people's enemy is gone, is gone!

ALL: Our enemy is banished! He is gone!

In rejecting Roman hospitality, Coriolanus risks challenging the sovereign's prerogative to establish the friend-enemy distinction, which for Carl Schmitt is at the core of sovereign power. The play's exposure of the distinction, however, is only its first step in recalibrating friendship's political potential. Coriolanus enters exile "alone, / Like to a lonely dragon that his fen / Makes feared and talked of more than seen" (4.1.29-31). He proclaims the isolation of his reject status, boasting to his mother Volumnia that he "[w]ill exceed the common" (4.1.32) and defy capture. Given his dramatic exit as an outcast who transforms rejection into a form of heroism, it is curious that by the end of act 4 the Roman reject seeks an alliance with Aufidius. In turning away from Roman hospitality to Aufidius, however, Coriolanus not only separates himself from classical notions of friendship that have been co-opted by the state, but he also exposes friendship's political force to its own limitations.

Coriolanus's language as he enters Aufidius's house in act 4 emphasizes conventional, early modern tropes of friendship and recalls the perversion that characterizes absolute hospitality. The rhetoric of hospitality sutures the divisions that previously separated the two rival warriors: "double bosoms" are now "one heart," "still together," "twin," and "unseparable" (4.4.13-16). He imagines a future in which foes "grow dear friends / And interjoin their issues" (22). The next scene in Aufidius's house reinforces this suture, as the stage directions announce that "Music plays" (4.5) and the servingman's repeated request for "Wine, wine, wine!" (1) creates a sense of plenitude at Aufidius's "hearth" (24). The companionship and plenitude suggested in the scene, however, prove equivocal, as the servingmen refuse to welcome Coriolanus into the "goodly house" (5). Framing the scene of friendship between rivals, then, is a division that persists beneath the hospitality established in the opening lines of the scene. Coriolanus acknowledges this lingering division as he enters: "The feast smells well, but I / Appear not 
like a guest" (5-6). The use of enjambment in these lines draws attention to the contrast ("but I") between hospitality's unconditional welcome and Coriolanus's inability to participate unconditionally in the plenitude. The caesura in the line appearing after Coriolanus's description of the pleasant smell of food and the conjunction "but" are formal reminders of the division that will subtend the two enemies' eventual union.

The servingmen's reaction to their guest, too, illustrates the tension between division and comity that informs the scene. Using the language of friendship in their address to Coriolanus, both servingmen express the ambivalence that, I am suggesting, is at the core of friendship in the scene. The First Servingman says, "What would you have, friend? Whence are you? Here's no place for you. Pray, go to the door"(7-9); followed by the Second Servingman, "Whence are you, sir? Has the port his eyes in his head, that he gives entrance to such companions? Pray, get you out" (12-14). Both servants describe Coriolanus in terms common in the rhetoric of friendship in the period, yet both reactions suggest that there is an aspect of Coriolanus that is not knowable: "Whence are you?" This question lingers as the play's acknowledgment that an unutterable truth—what Derrida calls the "nothing sayable" (1)—divides friendship and prevents it from being appropriated by sovereign absolutism in service of the state. Even as the ambiance of the scene-its music, its food, and its wine-intimates unity and hospitality, Coriolanus introjects division, insulting the servingmen by ordering them to "[f]ollow your function, go, and batten on cold bits" (4.5.31-32), and saying to another, "Thou prat'st, and prat'st. Serve with thy trencher. Hence!" (47-48).

The scene's ambivalence toward friendship and hospitality in the moments before the portrayal of the alliance between Aufidius and Coriolanus helps to shape how we might understand their strategic union. ${ }^{34}$ Coriolanus asks for an alliance based on revenge; in doing so, he intensifies his position as a reject-turning his passive disavowal of friendship into an active rejection, a "preemptive measure against lapsing into the all-too-human weakness for some amicability." 35 Coriolanus's decision to surrender to Aufidius, eventually offering his throat to his enemy as a gesture of his abjection, implies his renewed commitment to his rejection of the type of friendship offered by the state. Coriolanus tells Aufidius:

But if so be

Thou dar'st not this, and that to prove more fortunes

Th' art tired, then, in a word, I also am

Longer to live most weary, and present

My throat to thee and to thy ancient malice;

Which not to cut would show thee but a fool,

Since I have ever followed thee with hate,

Drawn tuns of blood out of thy country's breast,

And cannot live but to thy shame unless

It be to do thee service. 
In asking Aufidius to "make [his own] misery serve [Aufidius's] turn" (87), Coriolanus reminds us (and himself) that he is a reject in friendship, and he redirects the force of rejection against himself-a gesture intended to prevent any rapprochement with Rome. ${ }^{36}$

Aufidius's passionate reaction to his rival's offer reconfigures the proposed strategic alliance into a bond of friendship. He accepts Coriolanus into his home with the language of intimate hospitality:

But come in.

Let me commend the first to those that shall

Say yea to thy desires. A thousand welcomes!

And more a friend than e'er an enemy;

Yet, Martius, that was much. Your hand. Most welcome.

(4.5.142-146)

The surplus value in the hospitality voiced in Aufidius's greeting- "[a] thousand welcomes" and "more a friend than e'er an enemy"-risks obscuring the play's recognition of the disavowed truth that immanent in absolute hospitality is a form of antagonism that defines the political. The ambivalence at the core of this expression of hospitality helps to explain the remarkable interplay of eroticism and violence that characterizes Aufidius's extended response to Coriolanus:

Let me twine

Mine arms about that body, where against

My grainèd ash an hundred times hath broke, And scarred the moon with splinters. Here I clip

The anvil of my sword, and do contest

As hotly and as nobly with thy love

As ever in ambitious strength I did

Contend against thy valor. Know thou first,

I loved the maid I married; never man

Sighed truer breath; but that I see thee here,

Thou noble thing, more dances my rapt heart

Than when I first my wedded mistress saw

Bestride my threshold ...

Thou hast beat me out

Twelve several times, and I have nightly since

Dreamt of encounters 'twixt thyself and me.

We have been down together in my sleep, Unbuckling helms, fisting each other's throat, And waked half dead with nothing.

Aufidius's desire to "twine" his arms around Coriolanus's body is a reminder of his quest to defeat his Roman enemy, yet it is also a description of an 
embrace of unrequited love that previously had "scarred the moon" (108). After acknowledging that his "rapt heart" (115) prefers Coriolanus to his "wedded mistress" (116), Aufidius extends both the violent and erotic imagery of their new bond by describing how in his dreams their two bodies become one: "We have been down together in my sleep / Unbuckling helms, fisting each other's throat, / And waking half dead with nothing" (4.5.123-126). In Aufidius's rhetoric, their martial exploits morph into erotic play, and the two rivals merge into one indivisible body. The play's imagery highlights the migration from difference to similitude, and emphasizes the suturing power of the rhetoric that sustains an economy of friendship in early modern political philosophy. The violence embedded in the migration, however, captured in the active logic of the participles unbuckling and fisting, lets us glimpse the "motility of division" ${ }^{37}$-an ineradicable agonism-that structures a politics of friendship in this scene of hospitality.

Described as a "strange alteration!" (4.5.146), the new bond of friendship manifest in the event of hospitality suggests union and similitude between enemies, but the servingmen reveal an aspect of the bond that exceeds indivisibility. The second servingman says of Coriolanus: "I knew by his face that there was something in him. He had, sir, a kind of face, methought-I cannot tell how to term it" (153-155), and the first servingman seems to agree, "He had so, looking as it were-Would I were hanged, but I thought there was more in him than I could think" (156-158). The play points to the surplus that always exceeds friendship's claims of consensus and union, a silent surplus that conceals the truth about political friendship: that is, friendship is predicated on irreducible division and enmity. Again, the play allows a servingman to express most cogently the play's insight about friendship's immanent division: "But the bottom of the news is, our general is cut i' th' middle and but one half of what he was yesterday; for the other has half" (197-199). The servingmen anatomize and divide the alliance that in Aufidius's rhetoric of absolute hospitality was characterized by rapturous plenitude and erotic wholeness.

Though initially presented in terms that erotically imagine the unification of two bodies into one soul, Aufidius's understanding of hospitality's political force relies on the recognition that friendship's irreducible division is sutured by his own erotic rhetoric. The play hints at the covert nature of enmity-disguised, even as its presence is visceral in the imagery, by the erotic act of fisting each other's throats-in the servingmen's discussion of the ambivalence of Roman hospitality in the face of Coriolanus's return. The servingman responds to a discussion of the violence in store for the Roman people when Coriolanus returns to "mow all down before him" (4.5.201): "Do't? he will do't! for, look you, sir, he has as many friends as enemies; which friends, sir, as it were, durst not, look you, sir, show themselves, as we term it, his friends whilst he's in directitude" (205-208). Elaborating on his meaning, the servingman says, "But when they shall see, sir, his crest up again, and the man in blood, they will out of their burrows like conies after 
rain, and revel all with him" (210-212). The servants' discussion of covert, strategic friendship hints at its opposite-the irreducible, yet unspeakable hatred in the play that divides sovereign amity and fractures a concept of community predicated on it.

\section{Let Me Have War, Say I}

Aufidius's form of hospitality-embodying the political ideology of dissensus and not those attributes most associated with early modern friendship theory such as consensus, agreement, unity, or accord-is the productive force that drives polity. His actions after his allegiance with Coriolanus suggest that he accepts, indeed even demands as a necessity, the incommensurability of competing political claims. Shakespeare's description of the citizens in act 4, responding to the news of Coriolanus's return, reflects the play's interest in interrogating an alternative concept of community. The play no longer employs the logic of Menenius's belly metaphor to describe the citizens' relationship to the Roman state that integrates them into a seamless, functional political system. Indeed, by the end of act 4, Menenius twice calls the citizens "clusters." Describing the citizens' responsibility in banishing Coriolanus, Menenius says, "We loved him, / But like beasts and cowardly nobles, / Gave way unto your clusters, who did hoot / Him out o' th' city" (4.6.121-123). The second use of the word occurs a few lines later, as a troop of citizens enter the scene. Menenius responds to the citizens' arrival: "Here come the clusters. / And is Aufidius with him?" (128-129). According to the Oxford English Dictionary, the word clusters denotes a number of persons, animals, or things gathered or situated close together. In 1576, Abraham Fleming uses the word in a translation of Hippocrates to describe citizens who gather in a cluster, as in an assemblage, swarm, or crowd. ${ }^{38}$ This is the only use of this word in Shakespeare's entire body of work, and its appearance at this point in the play creates a distinction between how division operates early in act 1 and how the play understands its force by act 4 and 5. The rhetoric of friendship that shapes the belly metaphor in act 1—"good friend" (1.1.118), "incorporate friends" (1.1.121), "my good friends" (1.1.132) - is replaced by the concept of the cluster in act 4. As an assemblage, the cluster of citizens, I suggest, is an affiliation of differences, unintegrated by the belly metaphor into absolute sovereign power. Indeed, Menenius's second use of the word-"Here come the clusters. / And is Aufidius with him?"-implies its capacity to include division as a primary force. The statement and question in the passage align three of the play's antagonistic forces: common citizens ("clusters"), Aufidius, and Coriolanus ("him"). In doing so, Shakespeare imagines a politics that privileges division over incorporation and agonism over similitude.

Although the play ties Coriolanus's fate to Aufidius's jealousy at being overshadowed, or "darkened" (4.7.5), by the Roman warrior's exploits and reputation, his betrayal of Coriolanus is also a reaction to the threat of 
incorporation implied in Volumnia's seduction of her son back into Roman society. Volumnia embodies the threat of rapprochement that defuses a politics of friendship predicated on division. In her plea to her son to spare Rome, the power of Volumnia's appeal erases all antagonism and division:

If it were so that our request did tend

To save the Romans, thereby to destroy

The Volsces whom you serve, you might condemn us

As poisonous of your honor. No, our suit

Is that you reconcile them while the Volsces

May say "This mercy we have showed," the Romans,

"This we received," and each in either side

Give the all-hail to thee and cry, "Be blest

For making up this peace!”

Volumnia's peace accord imagines a form of consensus with the power to repair the divisive desires that compel vying factions. Her extended appeal in act 5 is an appeal for consensus that Coriolanus has already rejected. Volumnia's final words in the play, "And then I'll speak little" (5.3.182) contrast with her gregariousness immediately before her silence, and the stage directions after her long plea reinforce this contrast, as Coriolanus "holds her by the hand, silent" (5.3). By silencing Volumnia at the moment of her rhetorical victory, where she ensures accord, unity, and peace for Rome, the play dramatizes the problem of consensus. That is to say, Volumnia's silence even in her "happy victory to Rome" (5.3.186) jeopardizes her future political viability. Coriolanus's reaction to the new concord reinforces this point. He says to his mother:

But we will drink together; and you shall bear

A better witness back than words, which we,

On like conditions, will have counter-sealed.

Come, enter with us. Ladies, you deserve

To have a temple built you. All the swords

In Italy, and her confederate arms,

Could not have made this peace.

Coriolanus's words return us to a concept of sovereign amity associated with conventional friendship. His reaction stresses harmony with words such as "together," "like conditions," "counter-sealed," and "confederate arms." Rapprochement is complete; division repaired. Aufidius's aside at this moment, however, threatens the new concord: "I am glad thou hast set mercy and thy honor / At difference in thee. Out of that I'll work / Myself a former fortune" (5.3.200-202). His refusal to accept Roman hospitalityan insistence on the force of irreducible division-aligns him with the reject that enables a politics of dissensus critical in reshaping sovereign absolutism. 
With the collapse of the friend-enemy distinction in act 5 , Shakespeare's play tries to imagine the logical end to an early modern politics of friendship by reconfiguring traditional early modern models. In these models, the hospitality produced by consensual social bond of friendship is political as well in that it serves as the structure for civic engagement defined by parity, agreement, union, or accord. Entering the final scene, however, Coriolanus claims, "We have made peace / With no less honor to the Antiates / Than shame to th' Romans" (5.6.78-80). He brings with him the seal of the Roman senate that " $[t]$ ogether" with and "[s]ubscribed by" the tribunes represents what "[w]e have compounded on" (82-83). The language of consensus structures the scene but is quickly displaced by Aufidius's insistence on division, calling Coriolanus a "traitor" $(84,86)$. Coriolanus himself implores the Volsces to "[c]ut me to pieces" (110), insisting yet again on the threshold that sustains hospitality and on a polity structured on the logic and language of classical friendship theory. Coriolanus's demand that they cut him to pieces becomes the demand of the people as well as of the conspirators: "Tear him to pieces!" (119), the people shout, followed by the conspirators, who shout, "Kill, kill, kill, kill, kill him!" (128). Division remains but not at the expense of a community-to-come that can absorb the loss. Aufidius says to the lords present at Coriolanus's murder: "My lords, when you shall know ... the great danger / Which this man's life did owe you, you'll rejoice / That he is thus cut off" (5.6.134-137). After the murder, Aufidius says that his "rage is gone" (5.6.145) and that he is "struck with sorrow" (5.6.146) at the event. His reaction captures the ambivalence of a politics of friendship necessarily fueled by enmity as much as amity, difference as much as similitude. Aufidius's melancholic reaction is a reminder that the possibility of the death of a friend inhabits friendship itself as the irreducible division that creates desire and proves unsustainable an absolutist politics nurtured by conventional notions of sovereign amity. ${ }^{39}$

To conclude this essay on Shakespeare's representation of the potential of the politics of hospitality fueled by the force of friendship in Coriolanus that recognizes as a civic virtue the "dissension of a doit" (4.4.17), I want to return to the servingmen in act 4 . Responding to the hospitality between Aufidius and Coriolanus, the servingmen in act 4 offer, arguably, the most pressing insight into the play's political philosophy. After the compact between Aufidius and Coriolanus, the Third Servingman brings news of the impending war against Rome. His fellow servant asks, "But when goes this forward?" (4.5.213). The servingmen's exchange is as follows:

THIRD SERVINGMAN: To-morrow; to-day; presently; you shall have the drum struck up this afternoon ...

SECOND SERVINGMAN: Why, then we shall have a stirring world again. This peace is nothing, but to rust iron, increase tailors, and breed ballad-makers.

FIRST SERVINGMAN: Let me have war, say I; it exceeds peace as far as day does night; it's spritely, waking, audible, and full of vent. Peace is a very 
apoplexy, lethargy; mulled, deaf, sleepy, insensible; a getter of more bastard children than war's a destroyer of men.

SECOND SERVINGMAN: 'Tis so: and as war, in some sort, may be said to be a

ravisher, so it cannot be denied but peace is a great maker of cuckolds. FIRST SERVINGMAN: Ay, and it makes men hate one another.

THIRD SERVINGMAN: Reason; because they then less need one another.

On one level, this exchange articulates a concept of perpetual war that my reading of friendship and hospitality in the play risks ignoring. Indeed, to argue as I've done that Coriolanus's disdain for others, shaped by and articulated through the rhetoric of friendship, is in fact the play's expression of a counterpolitics to an absolutism obscured by the logic of sovereign amity is to seem to excuse the play's state-sanctioned violence. The play calls this militant force "a perpetual spoil" (2.2.117), and until Coriolanus's Rome has satisfied its imperial desire for "[b]oth field and city" (118), the war machine "never stood / To ease his breast with panting" (118-119).

The political philosophy of the servingmen, however, paints a different picture of perpetual conflict, one abstracted from the material effects of Coriolanus's particular rage. Conflict is naturalized and nourished in their description, "a parcel of their feast" and as immediate as the wiping of their lips. Conflict holds the promise to produce "a stirring of the world again"-an energy that contrasts with what peace brings- "nothing but to rust iron." In the final irony of the exchange, a servingman says that peace "makes men hate one another" because, he claims, "they then less need one another." Even as Coriolanus and Aufidius are necessarily hostages to Rome in a bond of friendship that has the two rivals "hate alike" (1.8.3), the irreducible division in their friendship gives the play's depiction of hospitality its political force. Rejection is embedded in Coriolanus's need for Aufidius and in Aufidius's reciprocal desire. It is a force in the play that ironically makes friendship asymmetrical, ${ }^{40}$ always appearing elsewhere, and according to the philosophical servingman, "a strange alteration," divided, fugitive, arriving “[t]omorrow, today, presently," like the fragile form of community that briefly, if only imaginatively, emerges from it.

The servingmen's mock encomium of war during this scene of hospitality dramatizes the antagonistic force of politics immanent in the new friendship between Aufidius and Coriolanus. To the servingmen, friendship produces "apoplexy" (4.5.223) and "lethargy" (223), and a world that is "mulled, deaf, sleepy, insensible" (223-224). In Schmittian terms, the friendship dramatized in the scene of hospitality worries the servingmen because it threatens to result in a "completely pacified globe." 41 With the confederation between Aufidius and Coriolanus, the servingmen witness simultaneously the birth of a new war machine-an assemblage with the potential to destroy Rome-and of an unconditional hospitality that guarantees a 
disturbing consensus. ${ }^{42}$ The Third Servingman describes the strange effect of the union: "our general is cut i' th' middle and but one half of what was yesterday" (4.5.198-199). The unconditional hospitality that characterizes the warriors' new friendship is a "strange alteration" not because the two warriors make awkward bedfellows. It is strange because their new confederation ironically suggests the possibility of a depoliticized world-a Roman republic without politics. In their reaction to the events that transpire in front of them, the servingmen echo Schmitt: "A world in which the possibility of war is utterly eliminated ... would be a world without the distinction of friend and enemy and hence without politics." 43 For the servingmen, the end of the political embodied in the warriors' strange alliance makes the turn to the absolute hostility of war- "a stirring world" (218-219)—necessary to recover a form of civic life.

\section{Notes}

This essay was revised during my time as a Lindsay Young Fellow at the Marco Institute of Medieval and Renaissance Studies at the University of Tennessee. I thank Professor Heather Hirschfeld for the intellectual and financial support to complete the project.

1. All references to Coriolanus are from William Shakespeare, The Norton Shakespeare, 3rd ed., ed. Stephen Greenblatt et al. (New York: W.W. Norton \& Company, 2016), hereafter cited parenthetically according to act, scene, and line attribution.

2. Jacques Derrida, Of Hospitality: Anne Dufourmantelle Invites Jacques Derrida to Respond, trans. Rachel Bowlby (Stanford: Stanford University Press, 2000), 75. See James Kuzner, "Unbuilding the City: Coriolanus and the Birth of Republican Rome," Shakespeare Quarterly 58, no. 2 (2007): 174-99. For an historical and cultural account of hospitality in early modern England, see Felicity Heal "The Idea of Hospitality in Early Modern England," Past and Present 102, no. 1 (1984): 66-93.

3. Laurie Shannon, Sovereign Amity: Figures of Friendship in Shakespearean Contexts (Chicago: University of Chicago Press, 2002), offers a trenchant account of early modern friendship. Although my understanding of the concept of friendship in Coriolanus will diverge from hers, my argument is indebted to her important work. For a recent account of friendship in terms of the force of generosity that is antecedent to politics and language, see Sean Lawrence, Forgiving the Gift: The Philosophy of Generosity in Shakespeare and Marlowe (Pittsburgh: Duquesne University Press, 2012). For criticism that emphasizes the productive nature of discord in the play, see Mareile Pfannebecker, "Cyborg Coriolanus / Monster Body Politic," in Posthumanist Shakespeares, ed. Stefan Herbrechter and Ivan Callus (New York: Palgrave Macmillan, 2012), 114-32.

4. Derrida, Of Hospitality, 123.

5. Ibid., 125.

6. Ibid.

7. Jacques Derrida, The Politics of Friendship, trans. George Collins (New York: Verso, 2005), 1, hereafter cited parenthetically in the chapter according to page number. John Florio's translation of Montaigne's essay is less polemical. 
He translates the phrase as, "Oh ye friends, there is no perfect friend" (n.p.). Montaigne uses this phrase to distinguish between perfect, or "soveraigne," friendship and the "vulgar and customarie" (n.p.).

8. Shannon, Sovereign Amity, 3.

9. Ibid.

10. Ibid., 5 .

11. Ibid.

12. Ibid., 8 .

13. Derrida, Politics of Friendship, 22.

14. Ibid. In Agonistics: Thinking the World Politically (London: Verso Books, 2013), Chantal Mouffe turns to Derrida's concept of hospitality to frame a theory of agonistic politics. For Mouffe, the agonism at the core of hospitality is a "confrontation where the aim is neither the annihilation nor the assimilation of the other, and where the tensions between the different approaches contribute to enhancing the pluralism that characterizes a multipolar world" (in Agonistics: Thinking the World Politically [Brooklyn, NY, and London, UK: Verso, 2013], 174-99, 41). Emmanuel Levinas's concept of “inter-humanity" in Entre Nous is another response to a politics of dissensus articulated through theories of friendship that inform how we might understand politics in the play. Levinas finds an ethical encounter with the Other prior to social and political formation to be the foundation of the social itself, not a product of it (see Entre Nous: On Thinking-of-the-Other, trans. Michael B. Smith and Barbara Harshav [New York: Columbia University Press, 1998]). He elaborates on this idea in Ethics and Infinity: Conversations with Philippe Nemo, trans. Richard A. Cohen (Pittsburgh: Duquesne University Press, 1985), 89-90. The intervention that this chapter makes in early modern politico-friendship theory contrasts with Levinas's argument about the prepolitical force of the ethical encounter. My own understanding of the limits of sovereign friendship as a political force is indebted to Tom Roach's illuminating discussion of the concept, especially his exploration of the politics of "approximate friendship" (13) and the productivity of the "anarchical contingency of all relationality" (13). See Friendship as a Way of Life: Foucault, AIDS, and the Politics of Shared Estrangement (Albany, NY: SUNY Press, 2012). I hope to show that Coriolanus and Aufidius's relationship resembles an approximate friendship that redefines the communal in their battle against it.

15. Quoted in Shannon, Sovereign Amity, 3.

16. Thomas Elyot, The Boke Named the Governour, ed. Foster Watson (New York: Everyman, 1907), 130.

17. Nicholas Grimald, "Of Friendship," in Tottell's Miscellany, ed. Richard Tottel (London: s.n., 1867), 145. I have changed the early modern long "s" (f) to the modern "s" for clarity.

18. Quoted in Shannon, Sovereign Amity, 4.

19. Ibid., 4.

20. Michel de Montaigne, The Essays of Montaigne, trans. E. J. Trechmann (Oxford: Oxford University Press, 1935), 188.

21. Ibid., 191.

22. Ibid., 189.

23. Elyot, Boke Named the Governour, 134.

24. Cicero, De Senectute, De Amicitia, De Divinatione, trans. William Falconer (Cambridge: Harvard University Press, 1928), 155. 
25. For a compelling account of the belly metaphor that stresses linguistic revolt in addition to civic strife, see Arthur Riss, "The Belly Politic: Coriolanus and the Revolt of Language," English Literary History 59 (1992): 53-75. See also Nate Eastman, "The Rumbling Belly Politic: Metaphorical Location and Metaphorical Government in Coriolanus," Early Modern Literary Studies 13, no. 1 (May 2007) 2.1-39, http://purl.oclc.org/emls/13-1/eastcori.htm; Alex Garganigo, "Coriolanus, the Union Controversy, and Access to the Royal Person," SEL Studies in English Literature 1500-1900 42, no. 2 (2002): 335-59; and Andrew Gurr, "Coriolanus and the Body Politic," Shakespeare Survey 28 (1975): 63-69.

26. Ivy Schweitzer, Perfecting Friendship: Politics and Affiliation in Early American Literature (Chapel Hill: University of North Carolina Press, 2006), 9.

27. For a discussion of potentiality as a political force in relation to notions of an unbounded community, see Giorgio Agamben, The Coming Community, trans. Michael Hardt (Minneapolis: University of Minnesota Press, 1993); and Jean-Luc Nancy, The Inoperative Community, trans. Peter Connor, Lisa Garbus, Michael Holland, and Simona Sawhney (Minneapolis: University of Minnesota Press, 1991).

28. Julia Reinhard Lupton, Citizen-Saints: Shakespeare and Political Theology (Chicago: University of Chicago Press, 2005), 60.

29. Graham Hammill, The Mosaic Constitution: Political Theology and Imagination from Machiavelli to Milton (Chicago: University of Chicago Press, 2011), 121.

30. Ibid., 23.

31. Mouffe, Agonistics, 175. Other recent work that explores representations of political alliances in the play include John Archer, Citizen Shakespeare: Freeman and Aliens in the Language of the Plays (New York: Palgrave MacMillan, 2005), 142-59; Oliver Arnold, The Third Citizen: Shakespeare's Theater and the Early Modern House of Commons (Baltimore: Johns Hopkins University Press, 2007; and Cathy Shrank, "Civility and the City in Coriolanus," Shakespeare Quarterly 54, no. 4 (2003): 406-23.

32. For a discussion of the underlying force of consensus in the citizens' voices in the fable of the belly, see Ann Kaegi, “'How apply you this?': Conflict and Consensus in Coriolanus," Shakespeare 4, no. 4 (December 2008): 379-84.

33. James Kuzner, Open Subjects: English Renaissance Republicans, Modern Selfhoods, and the Virtue of Vulnerability (Edinburgh: Edinburgh University Press, 2011), 101-3.

34. John Kerrigan is another critic who has observed a politics of friendship in this scene. Writing about their alliance in act 4 from a Derridean perspective, Kerrigan claims that " $[\mathrm{t}]$ heirs is a volatile, dangerous intimacy, one that, when it becomes political, will put Coriolanus at a disadvantage" (336). The power of Kerrigan's argument about this scene, however, emerges from his illuminating account of service and fidelity in the play. In his argument, the play's depiction of friendship and hospitality evoke the force of the promise or oath, and these speech-acts are the real binding events that link characters to each other and to their fate. See Kerrigan, "Coriolanus Fidiussed," Essays in Criticism 62, no. 4 (2012): 319-53.

35. Irving Goh, "Rejecting Friendship: Towards a Radical Reading of Derrida's Politics of Friendship for Today," Cultural Critique 79 (2011): 94-124, 106.

36. Ibid.

37. The term "motility of division" is Jacques Lezra's. For his illuminating discussion of this concept, see Wild Materialism: The Ethic of Terror and the Modern Republic (New York: Fordham University Press, 2010), 63-87. 
38. See Stanley Cavell, "Who Does the Wolf Love: Reading Coriolanus," Representations 3 (Summer 1983): 1-20, 3.

39. See A. J. P. Thomson, Deconstruction and Democracy: Derrida's Politics of Friendship (New York: Continuum, 2005), pp. 12-30.

40. I am indebted to David Wills for introducing me to the concept of asymmetrical friendship in "Full Dorsal: Derrida's Politics of Friendship," Postmodern Culture 15, no. 3 (2005): n.p. Wills writes about Derrida's concept of friendship: "But it is also, obviously, a figure of catastrophic inversion, a disruption of the symmetry and closure of a love or friendship that is presumed to function only in the faceto-face, and which therefore remains open to the politics of enmity" (par. 30).

41. Carl Schmitt, The Concept of the Political, trans. George Schwab (Chicago: University of Chicago Press, 1995), 35.

42. The servingmen's preference for war as a reaction to the strange eruption of hospitality between the two rival warriors illustrates yet another limit to a politics of friendship characterized by fraternity. The servingman's exclusion from the alliance points to the force of exclusion at the core of a democratic community emerging from fraternity. Derrida bases his critique of the fraternal democratic community on its gendered homogeneity: "although the figure of the friend, so regularly coming back on stage with the features of the brother-who is critically at stake in this analysis-seems spontaneously to belong to a familial, fraternalist, and thus androcentric configuration of politics" (vii). The hospitality exchanged between Aufidius and Coriolanus reproduces this exclusion in terms of gender to be sure, but for the servingmen the force of exclusion is also in terms of social hierarchy, qualifying friendship's radical potential dramatized in the scene.

43. Schmitt, Concept of the Political, 35. 


\section{Part II}

\section{Economy and Ecology}


This page intentionally left blank 


\section{Hospitality's Risk, Grace’s Bargain \\ Uncertain Economies in The Winter's Tale}

James Kearney

In the opening scene of The Winter's Tale, Shakespeare offers his audience a crash course in the social logic of hospitality. As the play opens, we learn that Polixenes and his Bohemian entourage have been enjoying the generosity of Leontes and the Sicilian court for nine months. Since the Bohemians cannot reciprocate in kind, the Sicilians' hospitality threatens them with the specter of crushing debt. Through the conversation between the courtiers Archidamus and Camillo, Shakespeare stages the Bohemians' sense that they are confronted with an oppressive obligation:

ARCHIDAMUS: If you shall chance, Camillo, to visit Bohemia on the like occasion whereon my services are now on foot, you shall see, as I have said, great difference betwixt our Bohemia and your Sicilia.

CAMILLO: I think this coming summer the King of Sicilia means to pay Bohemia the visitation which he justly owes him.

ARCHIDAMUS: Wherein our entertainment shall shame us; we will be justified in our loves. For indeed-

CAMILLO: Beseech you-

ARCHIDAMUS: Verily I speak it in the freedom of my knowledge. We cannot with such magnificence-in so rare-I know not what to say. ${ }^{1}$

A good reader of Marcel Mauss, Archidamus knows that the gift always exists within an economy of benefits and obligations, credit and debt. ${ }^{2}$ Indeed, his sense of insufficiency leaves him at a loss for words. Playing the part of the good host, Camillo insists that this concern is out of place: "You pay a great deal too dear for what's given freely" (1.1.16-17). But it is precisely the paradoxical nature of hospitable expenditure that is at issue in the play. For hospitality to be understood as gift, it must be figured as free. At the same time, as Archidamus intuits, gifts are never free.

The opening scene's invocation of an unease engendered by hospitality sets the stage for The Winter's Tale's meditation on the ways in which economic thinking-broadly construed-both subtends and compromises social relations. Economic logic haunts The Winter's Tale, shaping notions of love and service, friendship and fidelity, devotion and grief. ${ }^{3}$ And a crucial feature of this staging of a pervasive economic logic is 
the evocation of an idealized hospitality threatened by social and political realities. If Shakespeare dramatizes aggressive, potentially agonistic expenditure in this opening scene, he also flirts throughout the play with the possibility of expenditure without exchange, the possibility of some true act of hospitality. Shakespeare approaches the paradoxes of hospitality from a variety of perspectives in The Winter's Tale; perhaps most consequential is his decision to invoke the notion of grace. A term that Shakespeare returned to again and again in his work, grace was a remarkably elastic and resonant concept in early modern England generally and the world of Shakespeare's plays specifically. In this essay, I am concerned with the ways in which the term conjures both classical and Christian traditions, and moves across economic, aesthetic, and religious registers. Both Luther and Seneca deploy versions of grace to think about idealized forms of hospitality and generosity: transcendently harmonious social exchange in Seneca, the radically free, divine gift in Luther. In my argument, the repeated invocations of grace in The Winter's Tale link the fraught dynamics of giving and hospitality within the drama to the narrative movement from loss to redemption that Shakespeare foregrounds in the play's final acts.

That early modern England theorized hospitality-that it was a culture that attempted to think through acts of giving and receiving, charity and sacrifice, gratitude and indebtedness-has been well established. ${ }^{4}$ In the limited space of this chapter I can only gesture toward some of the depth and complexity of the culture's reflections on hospitality. My primary focus will be Shakespeare's staging of the logic of hospitality in The Winter's Tale, but in the course of my reading of the play, I turn to a variety of theorists of hospitable expenditure-Levinas and Derrida as well as Seneca and Luther-in an attempt to understand both why hospitality is such a vexed category in early modern thought and why it is so useful to think with. My contention is that the early modern desire to theorize hospitality and generosity stems, in part, from hospitality's peculiar position between idealized and agonistic relations, between the disavowal of the economic and the acknowledgement of the economic as an inescapable horizon. In The Winter's Tale Shakespeare seems particularly interested in exploring the notion that hospitality is defined by epistemological uncertainty and by the exposure to loss that such uncertainty entails. The tragic events of The Winter's Tale are a consequence of Leontes losing faith in the fidelity of his wife, Hermione. Following John Milbank, I read Leontes's original sin as refusing the original gift that Hermione offers, refusing the gift she gave when she opened her hand and took his (1.2.102-104). ${ }^{5}$ The Winter's Tale is a play concerned with hospitality's risks, risks that require one, as Paulina says, to awaken one's faith. And the uncertainty that haunts hospitable expenditure in The Winter's Tale works to make that expenditure more gratuitous, more akin to pure gift, even as it threatens it with not being a gift at all. 


\section{Twinned Lambs and Intimate Societies}

Surely oppression maketh a wise man mad: and a gift destroyeth the heart.

-Ecclesiastes 7:76

In the second scene of The Winter's Tale, we see first Leontes and then Hermione attempt to persuade Polixenes to extend his stay as guest, to accept more of the hospitality the Sicilians offer. Hermione finally attains Polixenes's consent to remain as guest by changing the terms of the argument:

Force me to keep you as a prisoner,

Not like a guest; so you shall pay your fees

When you depart, and save your thanks. How say you?

My prisoner or my guest?

If Hermione's lighthearted banter with Polixenes helps unveil the power relations in the guest-host dynamic, she immediately works to remystify those relations. ${ }^{7}$ After she persuades Polixenes to remain as guest, Hermione abruptly expresses interest in the kings' time together as boys:

HERMIONE: $\quad$ Not your jailer, then, But your kind hostess. Come, I'll question you Of my lord's tricks and yours when you were boys. You were pretty lordings then?

POLIXENES: We were, fair Queen, Two lads that thought there was no more behind But such a day tomorrow as today, And to be boy eternal

We were as twinned lambs that did frisk i'th' sun, And bleat the one at th'other; what we changed Was innocence for innocence-we knew not The doctrine of ill-doing, nor dreamed That any did. Had we pursued that life, And our weak spirits ne'er been higher reared With stronger blood, we should have answered heaven Boldly 'not guilty,' the imposition cleared Hereditary ours.

The famous description of the two monarchs as "twinned lambs that did frisk i'th' sun" gestures toward an origin myth that seems to govern symbolic relations between Bohemia and Sicilia. In the opening scene Camillo objected 


\section{2}

to Archidamus's fear of overwhelming debt by citing the extraordinary childhood friendship of Leontes and Polixenes as evidence that the Bohemians' fears were groundless. Here, Hermione invokes this narrative for the same reason that Camillo did in the previous scene: to maintain the view that the hospitality offered is given freely. As Camillo says, because of this origin myth, "Sicilia cannot show himself over-kind to Bohemia." Given that The Winter's Tale transforms hospitality into madness and tragedy, it is significant that, at the outset of the play, the hospitality of Sicilia toward Bohemia is consistently framed in relation to an impossible ideal: the kings' boyhood friendship.

The myth of the twinned lambs suggests a fundamental openness to the other person that evokes the primary human relation at the heart of Emmanuel Levinas's thought. ${ }^{8}$ Ethics is, famously, first philosophy for Levinas, and ethics is a function of an encounter with the other that Levinas often characterizes as, or in relation to, hospitality. In Totality and Infinity-which Jacques Derrida identified as "an immense treatise of hospitality" - Levinas devotes a section to "Dwelling" in which he suggests that hospitality is constitutive of dwelling, which is in turn constitutive of the human subject. ${ }^{10}$ For Levinas, the phenomenon of human dwelling is defined by the potential to receive the guest, by the prospect of the hospitable act: "The possibility for the home to Open to the Other is as essential to the essence of the home as closed doors and windows." 11 Home and dwelling are engendered by the hospitality they potentially afford. ${ }^{12}$ Given that in Shakespeare's Sicilia an idealized hospitality is grounded in the origin myth of the "two lads" who were "boy eternal," one might imagine that the conceptual space that Shakespeare's "twinned lambs" inhabit is proximate to Levinasian dwelling, that the myth of the twinned lambs describes a Levinasian encounter in which an absolute openness to the other constitutes the subject as ethical relation. I contend rather that Polixenes's description suggests a less well-known conceptual turn in Levinas's thought: his critique of the "intimate society."

Levinas is known as the philosopher of infinite obligation, a proponent of an absolute hospitality in which the self is hostage to the other. While impossible demands are at the heart of Levinas's thought, it must be remembered that the Levinasian demand is always situated in relation to the concrete situation in which we find ourselves; ethics, obligation, and hospitality are, for Levinas, always of this world. In an important essay that he published in the run-up to Totality and Infinity, Levinas offers a critique of what he calls the "intimate society," which is

a society of beings that are totally present to each other ... Such a truly intimate society is in its autarchy quite like the false totality of the ego. In fact, such a society is dual, a society of me and you. We are just among ourselves. Third parties are excluded. ${ }^{13}$

The model of the intimate society is the relation of lovers, the couple. It might seem strange for Levinas, the philosopher of the ethical relation, to critique 
any iteration of the love relation, but for Levinas this kind of love does not contain "social reality" since society "inevitably involves the existence of a third party." "To love in this way "is to exist as though the lover and the beloved were alone in the world." In the "intimate society" the "intersubjective relationship of love is not the beginning, but the negation of society ... The society formed by love is a dual society, a society of solitudes, excluding universality." 15 The emphasis on universality and a third person outside the intimate society is significant here in that this is the essay in which Levinas introduces his concept of le tiers (the third), the third party that frames and infinitely complicates the encounter between self and other. The figure of the third extends the self-other relation outward toward the social and the political and toward affective economies and ethical calculations. ${ }^{16}$ Crucially, the intersubjective arena opened up by the third points to a conception of the endlessly compromised space of human relations and to the endless acts of mediation (formal, aesthetic, economic) that constitute that space. If hospitality, for Levinas, is an uncompromising demand, it is also an inescapably compromised form of social, political, and economic life.

As The Winter's Tale opens, we are already in the space of Levinas's le tiers. If in the idyllic childhood friendship of the two kings Shakespeare offers us a vision of a relation before or beyond mere exchange, a vision that evokes hospitality outside economy, we learn that the two kings currently live in a world where friendly relations are necessarily mediated by political and economic realities and by the protocols of diplomacy and hospitality. As mentioned earlier, when Camillo objects to Archidamus's articulation of the social debt incurred by the Bohemians in the opening scene, he cites the extraordinary childhood friendship of Leontes and Polixenes:

Sicilia cannot show himself over-kind to Bohemia. They were trained together in their childhoods, and there rooted betwixt them then such an affection which cannot choose but branch now. Since their more mature dignities and royal necessities made separation of their society, their encounters, though not personal, hath been royally attorneyed with interchange of gifts, letters, loving embassies, that they have seemed to be together, though absent, shook hands as over a vast, and embraced as it were from the ends of opposed winds. The heavens continue their loves. $(1.1 .20-30)$

Camillo's desire to affirm the continued attachment of Leontes and Polixenes serves to highlight the loss of that bond. If the nostalgic tale of the kings' childhood relationship creates a mythical place without economy, their affection, rooted in childhood, must of necessity "branch" with maturation. In an attempt to overcome the division caused by this branching, their relation is "attorneyed" via "gifts, letters, loving embassies." However much Camillo wants to mystify the exchanges that define this relation between states, these royal proxies serve to emphasize distance and difference. 
Hermione herself becomes a form of hospitable mediation, commanded by her king to "speak" on behalf of Sicilia (1.2.27). ${ }^{17}$ Polixenes, of course, agrees to stay at the "good Queen's entreaty" when Leontes's "petitions" had no effect, a fact that seems to precipitate Leontes's mania $(1.2 .217,212)$. In a provocative essay, Howard Felperin entertains the counterintuitive argument that Hermione may have in fact been unfaithful. While I will not address Felperin's bracing act of critical intervention here, I do wish to take up Felperin's larger point about linguistic indeterminacy and epistemological uncertainty:

Why do we take for granted, as if it were a fact of nature, what can never be proved but only denied: that a king's wife has not had an affair with his best friend and nine months later given birth to an illegitimate daughter? How can we know that what has not been shown has not happened? In reaching the conclusion that we have unanimously reached as critics of the play, we have proceeded, indeed, been forced to proceed, in the absence of ocular or empirical proof, for how could there be ocular proof of what has not taken place? ${ }^{18}$

Felperin's point seems indisputable: the audience, like Leontes, can never truly know. The initial plot of The Winter's Tale is shaped by a tyrannical desire for certain knowledge running up against the inescapable reality of epistemological uncertainty. ${ }^{19}$ And throughout the play Shakespeare seems interested in addressing uncertainty in relation to the inherent risks of hospitality, which are also the risks of Levinasian ethics: to offer oneself, to expose oneself to the other.

The desire to know the other completely, the desire for certainty in relation to the other, is at the heart of Levinas's critique of the intimate society. In the intimacy of a love relation where "the presence of the other exhausts the content of ... society," the "affective warmth of love brings about the consciousness of ... satisfaction, contentment, plenitude." Against this self-satisfied and risk-free society, Levinas describes a form of love shaped by "universality," in which the third is present and all the messy realities of social, economic, and political life intrude. Crucially, the "universality of love," which embraces change and uncertainty, "can only be built up in time, by means of successive infidelities ... by the change of friends." Levinasian hospitality is then always a form of infidelity and a form of injustice ("the love of the neighbor depends on chance proximity; it is hence love of one being to the detriment of another, always privilege even if it is not preference" 20 ), but it is only in a relation where infidelity and injustice are possible that we can ever hope to arrive at something approaching justice or fidelity. There is an unresolved and unresolvable tension at the heart of Levinas's conception of hospitality, which points in two directions simultaneously. Levinasian hospitality is both infinitely demanding (and, therefore, impossible) and humble, fallen, always already compromised, always 
already mediated by language, politics, economics, the inescapable realities of the social world. ${ }^{21}$ Moreover, Levinasian hospitality is faithful to the demand of the other and is, therefore, constituted by a series of infidelities. ${ }^{22}$ In its opening scenes, The Winter's Tale stages the essential problematic of Levinasian hospitality by pitting the desire for some realm of true hospitality beyond the merely economic (twinned lambs, intimate societies) against the fallen and messy reality of hospitality. In doing so, it sets the stage both for the tragic losses that follow and for the possibility of some sort of redemption.

\section{“Take Hands, a Bargain”}

time and chance happeneth to them all.

—Ecclesiastes 9:11, KJV

Polixenes's story of original innocence implies a fall. Prompted by Hermione's intimation that the "pretty lordlings" have "tripped since," Polixenes implicates the two queens in this fall by suggesting that they tempted the monarchs out of their state of innocence and away from each other (1.2.75). Hermione interrupts his misogynist argument before it can go any farther:

\section{Grace to boot!}

Of this make no conclusion, lest you say

Your queen and I are devils.

"Grace to boot" is a curious exclamation in this context. Often used as an interjection like "Heaven help us," the phrase here takes the playful form of a prayer for intercession. ${ }^{23}$ And as Stephen Orgel notes, "to boot" is idiomatic for "into the bargain," and so Hermione would appear to be saying that "(you pay me) compliments in addition." 24 Hermione seems to be acerbically thanking Polixenes for this unlooked-for gift even as she playfully calls for divine aid in response to his misogynistic suggestion. And if grace has been thrown into the bargain, then perhaps Polixenes's narrative of a fall is-or can be rewritten as-a happy one.

Readers and audiences have long understood that grace is a significant concept in The Winter's Tale. Forms of the word occur thirty times within the text of the play, and in its audacious endgame the play seems interested in exploring the possibility of a return to some sort of grace after horrific crimes and devastating losses. ${ }^{25}$ Here, it seems significant that the term enters the play at Polixenes's mention of a fall from innocence. Without the fall, of course, there is no need for redeeming grace. Polixenes would attribute the death of innocence to the temptations of women, but Hermione playfully tells him to "make no conclusion, lest" he imply that "Your queen and I are devils" (1.2.80-81). Her interjection- "Grace to boot! / Of this 
make no conclusion"-is an intervention that rewrites this tragic fall into a comic felix culpa by resisting closure, by insisting that the story is not yet over. In a play that dramatizes despair as stasis and seems to celebrate fulfillment through time, Hermione's joke might be that the compensation (knowledge of women, sexual maturity, genealogical reproduction) is a greater good than the paradise allegedly lost. The movement from innocence to experience would then not simply initiate the circular process of exchange but would offer to engender what Paulina later calls "a surplus of ... grace" (5.3.7) that would move mere repetition into a new stage of possibility.

In response to Polixenes's attempt to paint the two queens as serpents seducing the two youths away from innocence, Hermione claims that she and her Bohemian counterpart will answer "Th'offences we have made you do" (1.2.82). Before she can continue this exchange with Polixenes, however, Leontes intervenes to ask if his fellow king is "won yet" (1.2.85). When he finds that Hermione has persuaded Polixenes to stay, Leontes says that she has never spoken "to better purpose" or, as he clarifies, "Never but once" (1.2.88). Hermione's witty response to this strange claim is also, I suggest, her answer to Polixenes's misogynist accusation:

What, have I twice said well? When was't before?

I prithee tell me

My last good deed was to entreat his stay.

What was my first? It has an elder sister,

Or I mistake you-O, would her name were Grace!

But once before I spoke to th' purpose? When?

Nay, let me hav't-I long.

Hermione here transforms the speech act to which Leontes refers ("Never but once" [1.2.88]) into a kind of original good deed. When Leontes reveals that this first instance of speaking well is-as Hermione and the audience intuit-her declaration of love for him, the audience sees how Hermione has skillfully positioned Leontes to answer Polixenes's charge. What Polixenes would claim as an original sin and fall from innocence-temptation of her future husband, here revealed as acquiescence to that husband's desireLeontes names a first good deed. Hermione playfully hopes that this first good deed-elder sister to her more recent example of virtuous speakingmight be named "Grace." And when Leontes names the first good deed for her, Hermione exclaims "Tis grace indeed" (1.2.104).

Hermione's reference to a Grace as an elder sister seems to mix registers, moving us from an anachronistic Christian narrative of a fall that allows for redemptive grace to the figures of the Graces from classical antiquity. Seneca offers an allegory of the Three Graces at the outset of his De Beneficiis. 
Begging the reader's indulgence, he offers to articulate the "force and property" of kindnesses, of doing "good turns," by explaining

why there be three Graces, why they be sisters, and why they go hand in hand: why they look smiling, why they be young, and why they be maids ... Some would have it meant thereby, that the one of them bestoweth the good turn the other receiveth it, and the third requiteth it ... Why walks that knot in roundel hand in hand? It is in this respect, that a good turn passing orderly from hand to hand, doth nevertheless return to the giver: and the grace of the whole is marred, if it be anywhere broken off but is most beautiful, if it continue together and keep his course ... Young they be, because the remembrance of good turns must never wax old. Virgins they be, because benefits must be without soil, pure, and holy to all men, wherein there ought to be no bondage nor constraint. ${ }^{26}$

In Seneca's vision of the graces, they establish the ideal of exchange as a beautiful dance in which benefits move from hand to hand in an unbroken circle that continues to come back around, so that giver and recipient are indistinguishable. In the midst of the circular dance, there is no hierarchy or originary moment, only the always already of harmonious exchange, pure and open, transparent and smiling. Seneca's vision of the Graces pushes in two directions at once. On the one hand, the image of harmonious movement offers a vision of expenditure and exchange that is social, human, an image not of stasis but of movement in time. On the other hand, the dance of the Graces suggests a perfection that evokes the divine, the inhuman.

One of antiquity's most sustained considerations of hospitable exchange, gift-giving, and the conferring of benefits, Seneca's treatise is fundamentally social and anthropological in perspective, anticipating not only Mauss's anthropology of the gift but also much modern thought on hospitality. And De Beneficiis is fundamentally concerned with the ways in which an act of generosity or hospitality can become an act of hostility or a source of resentment. ${ }^{27}$ If there is an idealizing thrust to Seneca's text, the fundamental question that Seneca pursues in the treatise is how to arrive at an idealized form of social exchange when everywhere he looks he sees hierarchical relations, debt, and ingratitude. ${ }^{28}$ Indeed, it is never precisely clear that Seneca believes that a pure exchange-however desirable and however useful as a desire-is possible. He suggests that in giving without concern for return or recompense, we should seek to resemble the gods: "[a]gain, the Gods immortal are not driven from their needful lavishness, though men be wicked and without regard of them. They use their own Nature, and bear with the wicked: yea, and they do good even to those that abuse their gifts. Let us then follow them for our guides, so much as man's frailty affordeth." ${ }^{29}$ This resemblance can only ever be partial; in giving we imitate the gods to the extent that our all too human weakness allows, "so much as man's frailty affordeth." Hospitality is always compromised; we offer what we-as humans—can afford to offer. 
In Christian terms Seneca's hospitality is fallen; unfolding within time, it is future-oriented, necessarily uncertain. If Seneca's reading of the three graces dresses up giving and hospitality in a vision of the possibility of social harmony through movement and difference, through a happy and pure exchange, then the image of the childhood friendship of Leontes and Polixenes is an image of an eternal present, fixed and timeless: "Two lads that thought there was no more behind / But such a day tomorrow as today, / And to be boy eternal" (1.2.62-64). The myth is then an idealized vision of social relations not simply outside the political and the economic, but, crucially, outside time and change. The play itself, however, is firmly situated within time's (or Time's) dominion, a domain in which acts of hospitality open onto the future and are thus full of risk. As an image of stasis in which there is no threat or exposure and no possibility of movement or change, the childhood paradise is, in a sense, the mirror image of the grieving Leontes that Time presents to the audience. With the power to "o'erthrow law" and to "o'erwhelm custom," Time "slide[s]" over "sixteen years" as if the audience "had slept between" (4.1.5-17). And it seems that Leontes has remained fixed in the posture of grief for those sixteen years: "Th' effects of his fond jealousies so grieving / That he shuts up himself" (4.1.18-19). In Time's brief description, Leontes becomes an emblem of grief; and the frozen, seemingly timeless grief of Leontes finds its objective correlative in the statue of Hermione. In The Winter's Tale Shakespeare gives us stasis as paradise in the childhood friendship of Leontes and Polixenes and stasis as hell or purgatory in the grief of Leontes and Hermione, but time and change ultimately come for and overwhelm both. The perfection of stasis (good or bad) gives way to compromise and mediation as these static figures fall into social life and cycles of exchange.

In the narrative that Polixenes offers to explain the fall from innocence to experience, the original, idyllic stasis is broken by desire and the risk that desire engenders. When Hermione asks when she first spoke well, Leontes's response frames her acceptance of his love within a scene of risk, the risk of holding out one's hand to another:

\section{Why, that was when}

Three crabbèd months had soured themselves to death

Ere I could make thee open thy white hand

And clap thyself my love; then didst thou utter

'I am yours for ever.'

To "clap thyself my love" is to take the loved one's hand, but it also suggests the striking of a bargain. The Oxford English Dictionary offers the relevant definition of clap: "to strike (hands) reciprocally in token of a bargain." 30 Later in the play, the Old Shepherd attempts to give his "daughter" Perdita to Florizel by suggesting they clap, or take, hands: 
"Take hands, a bargain; / And friends unknown, you shall bear witness to't- / I give my daughter to him" (4.4.378-380). By offering and taking hands, Hermione and Leontes begin a dance that is not a pure exchange outside of time but a series of compromised exchanges-bargainswithin time's dominion. As that which overthrows law and custom, Shakespeare's Time, however, mocks lovers' claims to transcend time through the gift of self. Leontes's account of Hermione's gift-“'I am yours for ever" play, when Leontes begins to lose faith in the gift he has been given. However true the giving of self might seem, however strong one's faith, in time it can always turn to poison. The fall out of innocence and into love's hand is both risk and bargain, a fall into the world of time and exchange that holds out the promise of surplus grace even as it threatens irredeemable loss.

In a discussion of the relation of Christian thought to the philosophical tradition's conception of moral luck, the contemporary theologian John Milbank addresses the central crime of The Winter's Tale-Leontes's lack of faith-as a version of the fall of man. For Milbank The Winter's Tale is a particularly useful story of the fall because it posits a prefallen state that "understands original blessedness by implication, not as deliberately 'doing good' but as a state of good moral luck, or reception of grace." On this account, original sin must then mean some kind of "refusal" of this moral luck,

a refusal that commences in the suspicion that one does not, after all, receive a good gift from the other. This is articulated better by Shakespeare than by Genesis: in The Winter's Tale ... [the fall] involves not a first misdeed by Leontes, but rather a first suspicion that Hermione has committed the sin of adultery. Here the fall is not an act, but rather a first mistrusting of the joyfully confident 'risk' and uncertainty constitutive of the field of action ... Hence, 'original sin,' on this rendering, is the imagination of sin, the reading of the unknown as source of threat or poison rather than potential or gift. ${ }^{31}$

While I ultimately part ways with Milbank in both his reading of The Winter's Tale and his understanding of the gift, this notion-that the original sin of The Winter's Tale is Leontes's failure to accept his state of moral luck or grace, his failure to accept the gift given-is crucial for my reading of the play. I follow Milbank in reading Leontes's original sin as refusing the original gift that Hermione offered when she opened her hand and took his (1.2.102-104). If Shakespeare seems particularly interested in exploring the notion of hospitality as risk in The Winter's Tale, these risks are more often than not simple, commonplace: opening one's home to a friend, offering one's hand to a lover or to a guest. Moreover, as the protracted stay of Polixenes suggests, the risk of such exposure persists over time. Leontes's story, I argue, is a story about the possibility of risking and sustaining faith in the 
gift given. And it is precisely Leontes's pathological certainty-a rejection of the uncertainty and risk that faith in another entails- that sets in motion the tragic events of the first three acts.

\section{Designing Hospitality, Offering Impossibility}

Present good is not yet altogether complete, some mischance may interrupt it; the future is in suspense, and uncertain.

-Seneca, De Beneficiis 3:4 ${ }^{32}$

It is often noted that the final scene of The Winter's Tale ostentatiously and anachronistically imports a cluster of Christian concepts into a play that is ostensibly set in pagan antiquity. The pervasive religious and Christian language-"chapel," "grace," "faith," "redeems," etc.-suggests that the audience is meant to experience this "resurrection" scene as somehow related to Christian thought. Even Paulina's name directs the audience to a Christian reading of the scene. It is less often noted that this final scene, like the opening of the play and the sheep-shearing festival, is explicitly a scene of hospitality. ${ }^{33}$ For the first time in the play, Leontes-who had so dishonored the office of host-is a guest.

The scene opens as the play does, with a discussion of hospitality and inordinate debt:

LEONTES: O grave and good Paulina, the great comfort

That I have had of thee!

PAULINA: What, sovereign sir,

I did not well I meant well; all my services

You have paid home. But that you have vouchsafed,

With your crowned brother and these your contracted

Heirs of your kingdoms, my poor house to visit,

It is a surplus of your grace which never

My life may last to answer.

LEONTES:

O Paulina,

We honour you with trouble; but we came

To see the statue of our Queen.

Paulina suggests that their relation is both economical and equitable; she not only has done good works in his service but has intended good, while he has paid her in full ("paid home"). She then suggests that the honor of receiving these royal visitors "is a surplus of your grace which never / My life may last to answer." These lines echo Polixenes's claim that Leontes's hospitality has placed him in perpetual debt. Here, Paulina reverses the terms, however, suggesting that she is indebted to Leontes for deigning to be her guest. In a characteristic move, Paulina has adroitly introduced the 
idea that she is offering hospitality to Leontes while seeming to suggest the reverse. Leontes dismisses this notion by observing that her guests "honour" Paulina "with trouble," another echo of Polixenes, who was concerned that the "charge and trouble" of his extended stay placed him in Leontes's debt. The echoes of the opening scenes give the audience the sense of coming full circle, of revisiting the scene of the original sin against hospitality.

If Paulina refers to the setting of the final scene as a "chapel," Leontes refers to it as a "gallery," a gallery filled with rare and wondrous objects ("singularities"), objects that Paulina evidently owns $(5.3 .86,10,12)$. And there is a curious moment when Paulina makes a point of claiming ownership of the statue of Hermione as well:

\section{Indeed, my lord,}

If I had thought the sight of my poor image

Would thus have wrought you-for the stone is mine-

I'd not have showed it.

\section{She moves to draw the curtain}

Paulina gives, and Paulina can take away. In this scene Paulina first establishes that Leontes is a guest in "my poor house" (note the proprietary claim) and then that the statue is her gift to bestow as she wills (5.3.6). Paulinaand by extension Shakespeare-takes great pains to stage this return within a scene of hospitality, to stage this resurrection as a gift. The question will be whether Leontes can accept the hospitality offered.

In the dramatic scene Paulina is staging, Leontes-who failed to have faith in the other, who failed to accept his own good fortune, the gifts he was given, who read his state of grace as fallen-must now accept the gift, the surplus of grace, Paulina offers. And it is a gift of a very particular kind: the kind of gift that, evidently, can only be received through an act of faith. As Paulina says, "It is required / You do awake your faith" (5.3.94-95). This is a more curious requirement than is often observed. Here, we have the inverse of doubting Thomas. Thomas refused to believe until he could see and touch, thereby becoming an emblem of the lack of proper faith. Paulina, in contrast, asks Leontes and the gathered nobles, as well as the audience, to perform an act of faith that requires no leap; she charges her audience to have faith precisely in what they see and touch, what is tangibly before them. We are enjoined to accept the scene as framed, as given, and we are told that this requires an act of faith. Crucially, Paulina is not asking us to believe in the possibility or plausibility of Hermione's return; on the contrary, she is insisting that we believe in it as we would something impossible. The language of faith here works to evoke the miraculous, the impossible.

If Seneca's De Beneficiis helped early modern culture theorize agonistic gifts and hospitable exchange, Luther was early modernity's great theorist of the possibility or impossibility of accepting the gift given. ${ }^{34}$ In elaborating 
his historically crucial understanding of grace, Luther theorizes the radically free gift, the impossible or unthinkable gift. Luther's somewhat alien and alienating conception of grace was available to readers of English in the early modern period primarily in the form of his Commentary on Galatians. ${ }^{35}$ And in his labored attempts to articulate his fraught understanding of righteousness and justification, works and faith, Luther consistently wrestles with the impossibility of thinking the free gift of grace. In the Commentary on Galatians, Luther suggests that "it is impossible for the human mind" to comprehend that God's grace is free. ${ }^{36}$ Since we are subject to "human weakness and misery" and faced with "the terrors of conscience," we conceive "nothing except our own works, our worthiness, and the Law." Because of this human weakness, "it is impossible for the human mind to conceive any comfort of itself, or to look only at grace amid its consciousness and terror of sin, or consistently to reject all discussion of works." And for Luther, the problem is that fallen man cannot break out of habituated logics of economic exchange; to escape the pull of economic logic long enough to understand the radically free nature of God's grace is simply "beyond human power and thought." ${ }^{37}$ Both Seneca and Luther figure a pure act of giving, a pure hospitality as otherworldly or inhuman: an ideal, a desideratum, a consummation devoutly to be wished, but only possible "so much as man's frailty affordeth.”

Luther's conception of grace in Commentary on Galatians anticipates Derrida's understanding of the gift in certain respects. Addressing the paradox of the gift, Derrida insists that the gift is only possible as gift if it is free:

For there to be gift, there must be no reciprocity, return, exchange, countergift, or debt. If the other gives me back or owes me or has to give me back what I give him or her, there will not have been a gift, whether this restitution is immediate or whether it is programmed by a complex calculation of a long-term deferral. ${ }^{38}$

At the same time, the gift is always and inevitably implicated in some sort of exchange. The gift always calls into being some kind of debt and payment, even if the debt is merely the expectation of gratitude from the recipient and the payment the self-congratulatory feelings of the donor. The giving of the gift is always, and indeed must be, thought of as aneconomic, and yet once the gift is recognized as gift it immediately enters the circle of exchange, the logic of the economic. Analyzing the paradoxes of the gift, Derrida proposes that the gift is impossible. ${ }^{39}$ The gift figures the impossible for Derrida just as, for Luther, it approaches the unthinkable. If Luther keeps insisting that reason cannot help us understand the gift, however, he also suggests that reason can and must point us to this very problem. In other words, in Luther's account-as in Derrida's—the only way for fallen man to think the gift is to think of it as impossible. For Luther this means that the proper 
understanding of the gift of God's grace can only be realized through the gift of God's grace. ${ }^{40}$ And to accept that gift, one must have faith.

The Winter's Tale offers us two fundamental readings of the statue scene: a faith-based reading that accepts the miraculous transformation in the statue and the resurrection of Hermione at face value; and a skeptical reading that views Paulina as the master of ceremonies at an elaborate-and really quite strange-deception. By requesting that Leontes and the audience awaken their faith, Hermione makes the request that every dramatist makes: that the audience accept the miracle of transformation and resurrection without looking too closely at the man or woman behind the curtain. ${ }^{41}$ The scene makes explicit what the theater demands of its audience: that we simultaneously suspend our disbelief and remain aware that we are under the spell of artifice. And in presenting the statue in the way that she does, Paulina offers what the theater so often offers: the gift of wonder, the gift of the impossible. To awaken one's faith is to accept Hermione's return as a deus ex machina, a manifestation of the impossible (God, gift) that isperhaps-always necessarily a bit of theater. And here the insistent articulation of an aesthetic realm in the scene-with its galleries and statues and singularities, with its evocation of "that rare Italian master Giulio Romano" (5.2.95)—establishes an artistic frame, establishes a theatrical design. The invocation of the aesthetic cues the audience to see the design at hand and perhaps to understand the ways in which hospitality is always a function of design, the ways in which hospitality always has designs on us.

And it is my argument that Paulina offers the impossible because this is a way for her to offer the gift of Hermione's return or resurrection freely. She must awaken the faith of Leontes specifically, precisely so that he can understand how to accept this free gift. For Luther, it is virtually "beyond human power and thought" to accept a gift as gift, outside of a logic of exchange, credit and debt, reward and punishment. For Leontes to awaken his faith in this context is to accept the impossible (Hermione's resurrection) and therefore accept the gift as gift. And if this is a miracle, then Leontes need not inquire into the intentions of Paulina and Hermione, need not weigh his sixteen years of loss and suffering against the recompense he receives, need not think in terms of debt and payment, sin and its forgiveness. If this is a miracle, then the erstwhile tyrant of Sicilia need not dwell too long on the "many / A prayer" he has offered "in vain ... upon her grave" (5.3.140-141). Paulina's hospitable design attempts to move the play toward reconciliation and harmony, to be sure, but it must also be read as an attempt to manage and secure Hermione's safe return to the social and political life of Sicilia. Given the fraught history the play recounts, such a return is necessarily hazardous.

The play's endgame is, of course, often read in terms of forgiveness and absolution. ${ }^{42}$ One way to read the "miracle" of this scene is that Leontes receives forgiveness for his seemingly unforgivable crimes. And, this would dovetail with a Derridean reading of giving and forgiveness since for Derrida it is precisely the unforgivable crime that occasions the possibility 
of true forgiveness. ${ }^{43}$ Here, however, I return to Levinas who rejects a notion of some absolute forgiveness in this world-not because it is impossible as Derrida would argue-but because it is undesirable. ${ }^{44}$ In Levinas's critique of the "intimate society," he takes special aim at a certain kind of forgiveness or absolution, what he calls "pardon":

pardon presupposes, above all, that the one wronged received all the evil of the wrong, and consequently disposes completely of the right to pardon ... But the conditions for legitimate pardon are only realized in a society of beings that are totally present to each other, in an intimate society. ${ }^{45}$

Levinas here critiques the fantasy of absolute pardon, a fantasy of forgiveness as something apart from political life and justice, a self-contained absolution that only implicates and concerns the benefactor and the beneficiary. For Levinas this absolute pardon and the kind of love-relation from which it derives participate in a totalizing logic that cordons off what Levinas calls "social reality." 46 The intimate society recreates Leontes's mad solipsism in binary form; here, we have the tyranny of the closed society. And it remains tyranny unless and until it welcomes the Levinasian third (le tiers), which ushers in the complex and confounding realities of political and economic life. ${ }^{47}$ In Levinasian terms the conception of forgiveness implied by a reading in which Hermione simply pardons Leontes is impoverished and dangerous, recapitulating the totalizing and tyrannical logic that helped lead Leontes to his crimes. And as Julia Reinhard Lupton reminds us, we see no such act of forgiveness in The Winter's Tale: Hermione never speaks to Leontes in the final "miraculous" scene, never addresses the possibility of forgiveness. ${ }^{48}$

The statue scene offers restoration as rebirth, with Paulina serving as midwife as Hermione is reborn into the social. And I contend that the staging of this return serves as an invitation to Leontes as well: Paulina's theatrical event solicits Leontes to reenter the world, to leave behind the static posture of penitence he has held for seventeen years and return from the dead, not because he has atoned sufficiently, but because forgiveness and justice unfold in the space of the political and the economic (what Levinas calls the space of the third) and through the experiential time of lives lived together. Forgiveness and justice are a function of the social world, which is a world of uncertainty and hazard. Through her elaborate hospitality, Paulina does not offer absolution but attempts to create the necessary conditions for rapprochement and reconciliation. When the statue "stirs" and Hermione descends, Paulina tells Leontes to present his hand as he did when Hermione "was young" and he "wooed her" (5.3.103-108). This is a reprise of that very first time Hermione spoke "well" in Leontes's account of their lives together, when she opened her hand to him and said "I am yours forever" (1.2.89-104). The gift offered is not forgiveness but the invitation to rejoin the world of time and change, risk and hope. 
Of course, if the gift is impossible, we cannot expect that Paulina's hospitable design, her attempt to create the conditions for some true act of hospitality, necessarily works. Critics often want to insist that this scene either succeeds in eliciting a kind of sublime wonder and thereby successfully figures redemption or that it fails to do so. I side with those critics who read this scene as, on the contrary, founded upon uncertainty. ${ }^{49}$ The invocation to faith calls forth the possibility of both belief and skepticism, and skepticism leads to inquiry, leads to narrative, leads to accounts and taking into account. The play keeps returning to questions of epistemology, keeps asking "How do you know?" And as Cavell writes, "an answer to the question 'How do you know?' is provided by specifying how you can tell." In Cavell's account "telling” pertains to the play's interest not only in tales, in relating and recounting, but in counting, "its preoccupation with computation" and exchange. ${ }^{50}$ And when the statue of Hermione comes to life, the spectators want her to speak, to give an account of herself. Camillo exclaims, "If she pertain to life, let her speak too!"; to which Polixenes adds, "Ay, and make it manifest where she has lived, / Or how stol'n from the dead" (5.3.113-115). Wanting this bizarre scene to add up, Polixenes asks for an account of the missing years, the gap in the story, the deficit in the narrative. But Hermione is not yet speaking, and Paulina isn't telling. In fact, Paulina short-circuits Polixenes's request for narrative, his request for knowledge, by suggesting that any such telling would be dismissed as a tale: "That she is living, / Were it but told you, should be hooted at / Like an old tale" (5.3.115-117). Paulina here thwarts Polixenes's potentially skeptical inquiry by suggesting that the skepticism that such a tale threatens to provoke precludes its being told.

When Hermione does speak, however, she not only begins to make an account of herself, but she figures that account as an exchange. Speaking for the first and only time in the scene, Hermione addresses her daughter, Perdita:

Tell me, mine own,

Where hast thou been preserved, where lived, how found

Thy father's court? For thou shalt hear that I,

Knowing by Paulina that the oracle

Gave hope thou wast in being, have preserved

Myself to see the issue.

Here again Paulina intervenes:

There's time enough for that,

Lest they desire upon this push to trouble

Your joys with like relation. 
Many editors and critics gloss Paulina's response to mean that Hermione should forbear recounting her narrative for fear that at this critical moment the assembled observers should wish to interrupt this joyful reunion with their stories, their narratives. ${ }^{51}$ But I read the potential troubling of joys that concerns Paulina as arising from the assembled group demanding "like relation"- "Where hast thou been preserved, where lived?"-from Hermione. Dramatically, Paulina is thwarting the expectations of the audience, onstage and off, interrupting the relation that we all want to hear. Neither Paulina nor her various audiences are concerned with these other stories, other narratives. We are concerned with Hermione's story, a story that threatens to undermine, indeed has already begun to undermine, the scene that Paulina is setting, the hospitality she is offering. In my reading, Paulina puts a stop to this exchange of tales because such an exchange will lead to what the audience on a certain level wants: a general giving of accounts, a weighing and measuring of suffering and loss that might very well lead to resentment and gifts repudiated. And, as it happens, the play ends with the promise or threat of just such an exchange.

In the final lines of the play, Leontes asks-or commands-his hostess to take them away from this gallery of miraculous hospitality, this chapel of impossible gifts:

\section{Good Paulina,}

Lead us from hence, where we may leisurely

Each one demand an answer to his part

Performed in this wide gap of time since first

We were dissevered. Hastily lead away.

If this proposed telling of tales promises a leisurely swapping of narrative gifts in a potentially idyllic moment of exchange that would bring together that which was dissevered, it also jeopardizes Paulina's carefully staged reconciliation with a hasty movement toward demands and answers, demands for answers, a general reckoning, a settling of accounts, which might very well poison the hospitality offered. The play then comes full circle, culminating not in redemptive closure but in deferral and dilation, in risk and possibility. If Leontes's story is, as I have argued, a story about the possibility of accepting, and maintaining faith in, the gift given, then his story does not come to an end with the end of the play. Paulina has attempted to create the conditions for a true act of hospitality, for a gift to be given and received, but the future, as always, remains uncertain. This is not to advocate a skeptical reading of the final scene of The Winter's Tale. My contention is rather that skepticism is simply a necessary condition of Paulina's gift-indeed, of all gifts-and one that haunts its future reception as well as its provenance. If the impossibility of the statue scene was invoked by Paulina's dramatic and theatrical hospitality, the gift of the impossible was never simply 
Paulina's to give. The potential marvel, rather, lies in the possibility of Leontes accepting. ${ }^{52}$ The wondrous turn the play hints at-but will not commit towould be for Leontes to accept the cup offered, to drink and, for once, not to look for the spider.

\section{Notes}

1. William Shakespeare, The Winter's Tale, ed. Stephen Orgel (Oxford: Oxford UP, 1996), 1.1.1-13. Subsequent citations from The Winter's Tale refer to this edition and will be cited in the text.

2. See Marcel Mauss, Essai sur le don: Forme et raison de l'échange dans les sociétés archaïques (1924); translated into English as The Gift: The Form and Reason for Exchange in Archaic Societies, trans. W. D. Halls (New York: W. W. Norton, 1990).

3. As Stanley Cavell notes in his classic essay on the play, the language of economics is everywhere in The Winter's Tale. See Cavell, "Recounting Gains, Showing Losses: Reading The Winter's Tale," in Disowning Knowledge in Six Plays of Shakespeare (Cambridge: Cambridge UP, 1987): 193-221. In addition to Cavell, I am particularly indebted to the following scholars in my reading of The Winter's Tale: Howard Felperin, “Tongue-tied our queen?': The Deconstruction of Presence in The Winter's Tale," in Shakespeare and the Question of Theory, eds. Patricia Parker and Geoffrey Hartman (New York: Methuen, 1985): 3-18; James Knapp, "Visual and Ethical Truth in The Winter's Tale," Shakespeare Quarterly 55, no. 3 (Fall 2004): 253-78; Julia Reinhard Lupton, Thinking with Shakespeare: Essays on Politics and Life (Chicago: University of Chicago Press, 2011), 161-85; John Milbank, "The Midwinter Sacrifice: A Sequel to 'Can Morality Be Christian?"” Angelaki 6, no. 2 (August 2001): 49-65; and Michael O'Connell, The Idolatrous Eye: Iconoclasm and Theater in Early Modern England (New York and Oxford: Oxford University Press, 2000), 138-44. I am also indebted to Jodi Mikalachki who presented a wonderful paper to the Medieval \& Renaissance Seminar at the University of Pennsylvania in March of 2001 titled "Figures of Grace: Favor, Form, and Forgiveness in The Winter's Tale."

4. For accounts of hospitality in early modern England, see Ilana Krausman Ben-Amos, The Culture of Giving: Informal Support and Gift-Exchange in Early Modern England (Cambridge: Cambridge University Press, 2008); Patricia Fumerton, Cultural Aesthetics: Renaissance Literature and the Practice of Social Ornament (Chicago: University of Chicago Press, 1991); David Goldstein, Eating and Ethics in Shakespeare's England (Cambridge: Cambridge University Press, 2013); Felicity Heal, Hospitality in Early Modern England (Oxford: Clarendon Press, 1990); Julia Reinhard Lupton, "Making Room, Affording Hospitality: Environments of Entertainment in Romeo and Juliet," Journal of Medieval and Early Modern Studies 43, no. 1 (Winter 2013): 145-72; and Daryl Palmer, Hospitable Performances: Dramatic Genre and Cultural Practices in Early Modern England (West Lafayette: Purdue University Press, 1992).

5. Milbank, "The Midwinter Sacrifice.” See discussion of Milbank below.

6. The King James or Authorized Translation of the Bible. The Holy Bible (London, 1611).

7. For a bracing analysis that sheds significant light on the power dynamics lurking in the shadows of the scene, see Michael Bristol, "In Search of the 
Bear: Spatiotemporal Form and the Heterogeneity of Economies in The Winter's Tale," Shakespeare Quarterly 42, no. 2 (1991): 145-67; 156.

8. For a reading of The Winter's Tale in relation to Levinas's thought, see Knapp, "Visual and Ethical Truth."

9. Jacques Derrida, Adieu, To Emmanuel Levinas, trans. Pascale-Anne Brault and Michael Naas (Stanford: Stanford University Press, 1999), 21.

10. The specter of Heidegger seems to hover over this argument (as it does over much of Levinas's thought) insofar as ethics, for Levinas, is fundamentally related to ethos in the Heideggerian sense of dwelling. For an extended analysis of the etymology of ethos in relation to ethics, which includes a discussion of Heidegger, see Dictionary of Untranslatables: A Philosophical Lexicon, eds. Barbara Cassin et al. (Princeton, NJ: Princeton University Press, 2014), 691-9. My understanding of the relation of both Heidegger and Levinas to hospitality is indebted to Tracy McNulty, The Hostess: Hospitality, Femininity, and the Expropriation of Identity (Minneapolis: University of Minnesota Press, 2007), especially vii-xxii.

11. Emmanuel Levinas, Totality and Infinity: An Essay on Exteriority, trans. Alphonso Lingis (Pittsburgh: Duquesne University Press, 1969), 173.

12. Moreover, the dwelling from which one welcomes the stranger is no more (and no less) than the phenomenological condition of a subjectivity that is open to the other, that has the capacity to welcome. In Totality and Infinity, Levinas names "subjectivity" as that which welcomes the other, "as hospitality" (27).

13. E. Levinas, "The Ego and the Totality," in Collected Philosophical Papers, trans. Alphonso Lingis (Dordrecht, Netherlands: Martinus Nijhoff Publishers, 1987), 30. I follow Robert Bernasconi in believing that we learn much about Levinas's thought concerning politics, economics, and justice by tracking the consequences of this essay into Levinas's more mature articulations of his philosophy in Totality and Infinity and Otherwise than Being. See Bernasconi, "The Third Party: Levinas on the Intersection of the Ethical and the Political," Emmanuel Levinas: Levinas, Phenomenology and His Critics, eds. Claire Katz and Lara Trout (London: Routledge, 2005), 45-57.

14. Levinas, "The Ego and the Totality," 32.

15. Ibid., 31.

16. On the importance of the concept of le tiers to Levinas's thought generally, see Bernasconi, "The Third Party"; Simon Critchley, "Five Problems in Levinas's View of Politics and the Sketch of a Solution to Them," Political Theory 32, no. 2 (2004): 172-85; and Howard Caygill, Levinas and the Political (London: Routledge, 2002).

17. For a fascinating take on the "publishing" of Hermione at this moment via the platform and protocols of hospitality, see Lupton, Thinking with Shakespeare, 168-77.

18. Felperin, “Tongue-tied our queen?", 5.

19. Cavell reads Leontes's desire for certain knowledge of the other as an extreme form of skepticism that results in a failure to acknowledge the other. For Cavell, Leontes is "the portrait of the skeptic as fanatic," a skeptic who embraces not "an opposable doubt but an unappeasable denial, a willful uncertainty that constitutes an annihilation." See "Recounting Gains," 206.

20. Levinas, "The Ego and the Totality," 31.

21. In "Dwelling," Levinas insists that the event of the face of the other is not simply to be understood as a welcoming, "as hospitality" but hospitality as embedded 
in the realities social and economic life (broadly construed): "the transcendence of the face is not enacted outside of the world ... The 'vision' of the face as face is ... a certain form of economic life. No human or interhuman relationship can be enacted outside of economy; no face can be approached with empty hands and closed home" (Totality and Infinity, 172).

22. For a discussion of hospitality in relation to infidelity, see McNulty, The Hostess, 87-174.

23. Orgel suggests that the phrase is often read "on the model of 'St. George to boot' (Richard III, 5.6.31)." See the note to 1.2.79 in his edition of The Winter's Tale.

24. Orgel, note to 1.2.79. When Camillo persuades Autolycus to exchange clothing with Florizel later in the play, he entices him with something extra: "there's some boot" (4.4.631-632). Playing comically with the serendipitous consonance between his new footwear and his sudden windfall, Autolycus exclaims, "What an exchange had this been, without boot! What a boot is here, with this exchange!” (4.4.670-672).

25. There is an ongoing debate concerning the nature and kind of theological commitments that may or may not be expressed in The Winter's Tale that necessarily touches on the play's relationship to secular and sacred notions of grace. See Huston Diehl, “'Strike All that Look Upon With Marvel': Theatrical and Theological Wonder in The Winter's Tale," in Rematerializing Shakespeare: Authority and Representation on the Early Modern English Stage, ed. Bryan Reynolds and William West (New York: Palgrave MacMillan, 2005), 19-34; Ken Jackson "'Grace to boot': St. Paul, Messianic Time, and Shakespeare's The Winter's Tale," in The Return of Theory in Early Modern English Studies, ed. Paul Cefalu and Bryan Reynolds (New York: Palgrave MacMillan, 2011), 192-201; Julia Reinhard Lupton, Afterlives of the Saints: Hagiography, Typology, and Renaissance Literature (Stanford: Stanford University Press, 1996), 175-218; O'Connell, The Idolatrous Eye.

26. The woorke of the excellent philosopher Lucius Annaeus Seneca concerning benefyting (London: John Day, 1578), trans. Arthur Golding, 1:3 (A3r-A3v). Unless noted otherwise, subsequent citations from Seneca's De Beneficiis refer to this translation and will cite book and chapter of the text as well as the page in this edition. When quoting Golding's translation, I have modernized some aspects of the spelling. I am grateful to Jodi Mikalachki for drawing my attention to this passage in the Seneca.

27. Seneca, 1:1 (A1R).

28. And this means that most of Seneca's extraordinary anatomy of the gift consists of a rehearsal of all the ways in which gift-exchange can and does go wrong. As he says in a discussion of gifts that should not be considered ethically binding, "poison hath some times healed a man; and yet is it not therefore counted a wholesome thing” (Seneca, 2:18 [E4v]).

29. Seneca, 1:1 (A2r).

30. In support of this definition, the Oxford English Dictionary cites this passage from The Winter's Tale as well as Henry's wooing of Katharine in Henry V: "Give me your answer, i' faith, do; and so clap hands and a bargain. How say you, lady?” (5.2.130-132). See also Orgel, note to 1.2.103.

31. Milbank, "The Midwinter Sacrifice," 57.

32. Seneca, On Benefits, trans. Aubrey Stewart (London: George Bell and Sons, 1887), 55-56. 
33. Although see Lupton, Thinking with Shakespeare, 179.

34. The Reformation intervention in the Christian theology of grace marks an important development in the history of the gift. And as Natalie Zemon Davis and others have shown, this theological transformation had very real consequences for the social practice of gift-giving. See Davis, The Gift in Sixteenth-Century France (Madison: University of Wisconsin Press, 2000), especially 100-123. For discussions of some of the consequences of the Reformation's conception of grace as gift for early modern literature, see Brian Cummings, The Literary Culture of the Reformation: Grammar and Grace (Oxford: Oxford University Press, 2002), 47-53, 319-27; and Richard Strier, Love Known: Theology and Experience in George Herbert's Poetry (Chicago: University of Chicago Press, 1983). For a reading of the gift in Timon of Athens that informs my own understanding of grace and hospitality in Shakespeare, see Ken Jackson, “'One Wish' or the Possibility of the Impossible: Derrida, the Gift, and God in Timon of Athens," Shakespeare Quarterly 52, no. 1 (2001), 34-66.

35. On the significance of Luther's Commentary on Galatians to the dissemination of certain aspects of Lutheran thought in England in the sixteenth and seventeenth centuries, see James Kearney, The Incarnate Text: Imagining the Book in Reformation England (Philadelphia: University of Pennsylvania Press, 2009), 155, 268.

36. "It is impossible for the human mind to conceive any comfort of itself, or to look only at grace amid its consciousness and terror of sin, or consistently to reject all discussion of works" (Luther's Works, 26:5). On Luther and the paradoxes of the gift, see Kearney, The Incarnate Text, 119-28.

37. Luther's Works, 26:5.

38. Derrida, Given Time: 1. Counterfeit Money, trans. Peggy Kamuf (Chicago: University of Chicago Press, 1992), 12.

39. For Derrida, it is "the very figure of the impossible" (Given Time, 7).

40. Luther's Works, 26:26.

41. For a reading of the scene as requiring "poetic faith or the willing suspension of disbelief," see Richard McCoy, Faith in Shakespeare (Oxford: Oxford University Press, 2013), 113-45; 141.

42. For a recent account of the complexities of forgiveness in The Winter's Tale, see Sarah Beckwith, Shakespeare and the Grammar of Forgiveness (Ithaca: Cornell University Press, 2011), 127-46.

43. "[F]orgiveness forgives only the unforgivable," Jacques Derrida, On Cosmopolitanism and Forgiveness, trans. Mark Dooley and Michael Hughes (New York: Routledge, 2001), 32.

44. The point here is not to oppose Derrida's and Levinas's conceptions of forgiveness, which are not ultimately incompatible in my view. Rather, I opt for Levinas's critique of the "intimate society" because I think it speaks more directly to the ways in which the logic of a certain kind of "pardon" echoes Leontes's tyrannical solipsism.

45. Levinas, "The Ego and the Totality," 30. Emphasis in original.

46. Ibid., 32 .

47. For Levinas the intimate society remains a totalizing relation unless or until it "becomes judgment and justice" ("The Ego and the Totality," 32).

48. Lupton makes a compelling argument that the statue scene conjures a public theater of blessing and benediction rather than an intimate act of forgiveness. See "Unforgiving Winter's Tale: Staging Judgment in Hannah Arendt and W. H. Auden," New Literary History 45 (Autumn 2014): 641-63. 
49. In addition to Cavell, Disowning Knowledge; Felperin, "Tongue-tied our queen?"; and Knapp, "Visual and Ethical Truth in The Winter's Tale," see Kenneth Gross, The Dream of the Moving Statue (Ithaca: Cornell University Press, 1992), 100-109; and Walter Lim, "Knowledge and Belief in The Winter's Tale," Studies in English Literature, 1500-1900 41, no. 2 (Spring 2001): 317-34. On linguistic uncertainty in The Winter's Tale, see Lynn Enterline, "'You Speak a Language that I Understand Not': The Rhetoric of Animation in The Winter's Tale," Shakespeare Quarterly 48, no. 1 (Spring 1997): 17-44; and Stephen Orgel, “The Poetics of Incomprehensibility," Shakespeare Quarterly 42 (1991): 431-7.

50. Cavell, Disowning Knowledge, 201, 199.

51. For a range of responses to this passage, see the note in the New Variorum Edition of Shakespeare's The Winter's Tale, ed. Robert Kean Turner and Virginia Westling Haas (New York: Modern Language Association of America, 2005). I concur with David Bevington who reads the passage to mean that "lest they desire, at this stressful time, to trouble you by demanding like relation of your story." See William Shakespeare, The Late Romances, ed. David Bevington (New York: Bantam Books, 1988), note to 5.3.131-132.

52. On the importance of Leontes's reception of the gift, see David Schalkwyk, Shakespeare, Love and Service (Cambridge: Cambridge University Press, 2008), 290-6. 


\title{
5 Hospitality in Anthony and Cleopatra
}

\author{
Sean Lawrence
}

If we are to believe Enobarbus, the title characters of William Shakespeare's Anthony and Cleopatra initiate their relationship with dueling offers of hospitality:

Upon her landing, Anthony sent to her, Invited her to supper. She replied, It should be better he became her guest, Which she entreated. ${ }^{1}$

These initial invitations suggest an exchange, even a purchase. Anthony, Enobarbus claims, "for his ordinary pays his heart / For what his eyes eat only" (2.2.232-233). Enobarbus's language implies a poor bargain. The Oxford English Dictionary defines ordinary as "customary fare; a regular daily meal or allowance of food." ${ }^{2}$ Enobarbus characteristically describes events in military terms; in this case, he deflates Cleopatra's extravagant (one assumes) hospitality to mere rations. Moreover, it is a meal for which Anthony overpays, with his very heart, for what "his eyes eat only." The relationship that gives the play its name finds its origin in hospitality, but this hospitality evokes the language of commerce.

Hospitality is not only a relationship between characters-a relationship of welcome, of solicitude and of love-but also an expression of this relationship, an expression that can be abstracted from the relationship itself. Signs of hospitality are no more stable than other signs, and therefore prove unable to assure characters of their relationships to one another. Enobarbus remarks that the defectors from Anthony to Caesar "have entertainment, but no / Honourable trust" (4.6.16-17). Similarly, Anthony and Cleopatra never quite trust each other, though they struggle with hyperbolic hospitality to ratify their union by ever-greater entertainments. Neither character can be assured that the ceremonies of hospitality show a true welcome and not merely a political manipulation. In what follows, I contrast Emmanuel Levinas's philosophy of hospitality, especially as expounded after his death by Jacques Derrida, to Marcel Mauss's anthropology of the gift, to argue that not only do the characters of Shakespeare's play in fact fail to create stable relationships through hospitality but also that they must fail. 
While a relationship can be built on exchange, it can never overcome the suspicion of being merely tactical, self-serving, or temporary.

Specifically, hospitality can always be understood as part of a power relation. Derrida opens his treatment of Levinas's philosophy by acknowledging the suspicions elicited by hospitality. He references Émile Benveniste's etymology of the word host, the French equivalent of which can also mean "guest." Benveniste points out that in Latin hostis can even denote a foreigner or a public enemy. ${ }^{3}$ He follows Mauss in seeing hospitality as a gift offered in an exchange, demanding reciprocation and therefore threatening. Where Benveniste explicates the double-meaning of host in Latinate languages, Mauss shows that the word gift has a double meaning in Germanic languages, with German maintaining the meaning of "poison" and English the meaning of "present," while Dutch maintains both meanings, distinguished only by grammatical gender. Moreover, this double meaning alludes to the potential threat of gifts in many cultures. Mauss compares ancient Germanic culture to Maori culture, where "[c]oming from one person, made or appropriated by him, being from him, [the gift] gives him power over the other who accepts it." In the Germanic context, Mauss notes, gifts are almost always understood as drinks and, moreover, "[t]he drink-present can be a poison; in principle, with the exception of a dark drama, it isn't; but it can always become one." In any case, "[i]t is always a charm" making a permanent claim on both the donor and recipient. ${ }^{4}$ Mauss underscores the importance of hospitality, especially of consumables, as a gift, and shows how it always remains a potential threat. Benveniste credits him with having "showed that the gift is only one element in a system of reciprocal prestations," "5 and applies Mauss's theory of reciprocal gift-giving to hospitality:

Through hostis and the related terms in early Latin we can discern a certain type of compensatory offering that is the basis of the notion of 'hospitality' in the Latin, Germanic, and Slavic societies; equality of status transposes into law the parity between persons confirmed by reciprocal gifts. ${ }^{6}$

There are two reasons to be dubious of hospitality, though they often imply one another. To begin with, hospitality may be false and dishonest: one thinks of Anthony's welcome of Octavia shortly before deciding that "I' th' East my pleasure lies" (2.3.38). Second, even a conscientious act of hospitality would nevertheless take place within a structure of reciprocal gift-exchange, where every gift stakes an insidious claim and where, therefore, every gift may be a poison and every host is potentially hostile. Shakespeare does not depict Pliny's anecdote in which Cleopatra wins a bet with Anthony by swallowing a pearl dissolved in vinegar, perhaps because he does not wish to remind his audience of the "union" used to poison the wine (and hence Gertrude) at the end of Hamlet. ${ }^{7}$ In Anthony and Cleopatra, only the clown's gift of figs proves literally poisonous, but 
all gifts nevertheless retain the poisonous potential that Mauss describes. All may impose insidious claims upon the recipient.

Derrida cites Benveniste in contrast to Emmanuel Levinas. ${ }^{8}$ I have argued elsewhere that Levinas's understanding of generosity contrasts with Mauss's. ${ }^{9}$ More relevant to the purposes of this volume, Levinas offers an understanding of hospitality, like that of gift, which contrasts it with competitive exchange. Derrida makes the counterintuitive claim that "[a]lthough the word is neither frequently used nor emphasized within it, Totality and Infinity bequeaths to us an immense treatise of hospitality." The claim becomes less counter-intuitive a few pages later, when Derrida adds that " $[\mathrm{t}]$ hough the word 'hospitality' occurs relatively seldom in Totality and Infinity, the word 'welcome' is unarguably one of the most frequent and determinative words in that text." 10 The ethical command which Levinas finds in the face of the Other can also be understood as the welcome of the Other in primordial, preoriginal hospitality. This hospitality is radical, Derrida specifies, "not simply some region of ethics, let alone, ... the name of a problem in law or politics: it is ethicity itself, the whole and principle of ethics." ${ }^{11}$ Levinasian hospitality therefore comes before all possible hostility. With a rhetorical question, Derrida suggests that Levinas's philosophy of hospitality would "in effect require us to think law and politics otherwise." 12 The term politics is particularly apposite, because Mauss finds a power relationship in gift-exchange and in particular hospitality. A leader in the cultures Mauss studies

sustains his rank among the chiefs by giving back bracelets for necklaces, hospitality for visits, etc. In this case riches are from every viewpoint as much a means of retaining prestige as something useful. Yet are we sure that it is any different in our own society, and that even with us riches are not above all a means of lording it over our fellow men? ${ }^{13}$

Mauss's rhetorical question extends the range of his claim from the so-called primitive cultures that furnish the objects of his anthropology to his own European contemporaries. Instead of political relations, Levinas talks of ethical relations and, increasingly toward the end of his life, of love as an even better label for the sort of nonreciprocal relationship that Derrida would, after his death, term hospitality. ${ }^{14}$ Derrida carefully refuses to make Levinas's "ethics ... of hospitality" into the foundation for a "law or politics of hospitality," preserving its radicality against appropriation by any discrete polemical position. To Levinas, hospitality would not be a politics but an ethical command preceding social conventions.

Levinas's radical understanding of ethics places it prior to politics but also prior to semiotics. Indeed, he argues that the ethical response to the Other inspires language in the radical sense of a response, a welcome of the Other, as a Saying. He explains this in an interview with Philippe Nemo: "The saying is a way of greeting the Other. ... It is difficult to be silent in 
someone's presence; this difficulty has its ultimate foundation in this signification proper to the saying, whatever is the said." 15 The Said, on the other hand, designates language as signification and structure or, in the words he used in a conference at the University of Ottawa, "all that can be written."16 Each act of hospitality can be understood as simultaneously a Saying and a Said, because every act of hospitality constitutes an address, a welcome of an Other, but also and at the same time an expression that must take the form of signs, if not always of spoken or written words. Greetings, welcomes, and acts of hospitality usually assume the form of the social conventions described by cultural anthropology, but arise from the primordial ethicity of hospitality. "In language qua said," Levinas writes, "everything is brought before us, albeit at the price of a betrayal." ${ }^{17}$ In this sense, every welcome is at once radical and conventional.

In the play, Anthony and Cleopatra's love appears excessive and is certainly self-defeating. They ignore, indeed actively reject, the exigencies of politics in favor of excessive and self-giving love, giving away everything, even themselves, and therefore essaying hospitality in the radical sense Derrida finds in the work of Levinas. However, because their love takes expression in words, ceremonies, or objects given and received, it still elicits suspicions of falsehood. Hospitable words, hospitable actions, and hospitable gifts all participate in the instability of the sign, and therefore offer themselves to suspicion. Moreover, though hospitality as ethics or love exceeds political calculation, its very expression transforms it into hospitality in the Maussian sense, where every gift demands reciprocation within a struggle for power and prestige. The play is set in a political world-indeed, a pagan world of war, before "the time of universal peace" anticipated by Caesar (4.6.4) —and in this world every act of hospitality generates political ramifications. Every apparently loving act can be taken as an effort at control. The very excess of these gestures of hospitality, however, shows their inspiration in radical hospitality, hospitality in the Levinasian sense, closely related to ethics and even more to love. The protagonists' extravagant donations condemn them to gift-exchange, but show a determination to break free of this logic, to exceed it. By its very manifestation, the hospitality of the title characters betrays itself.

Because hospitality expresses itself as words and ceremonies, because it inevitably becomes Said, it can be misapplied. This is a general philosophical problem, so it is not surprising to find it in many contexts, including early modern contexts. The most important historian of early modern English hospitality, Felicity Heal, and the foremost historian of early modern French gifts, Natalie Zemon Davis, concur in finding a theological injunction at the root of practices of hospitality and generosity. In Heal's words, the biblical message "spoke of the paramount need of the outsider and the poor, and therefore promoted an identification between household charity and household entertainment." Nevertheless, "it was common for prescriptive writers to acknowledge that entertainment had to be governed both by an 


\section{Sean Lawrence}

acceptance of existing social convention and by the constraints of intelligent financial management." ${ }^{18}$ According to Davis, gift-giving in early modern France was governed by two "age-old core beliefs," the first of which derived from Christianity: "everything we have is a gift from God, and what comes in as a gift has some claim to go out as a gift." The second core belief derived from pagan antiquity but also took form in popular expressions in social practices. It emphasized reciprocity. ${ }^{19}$ To both historians, a radical belief in hospitality and generosity takes a quotidian, measured expression. Indeed, both emphasize instances of gifts gone wrong and hospitality that fails. Davis even cites the cynicism of Shakespeare's Timon, who declares that "each thing's a thief," but also outlines John Calvin's insistence on the status of Grace as a radically unilateral, nonreciprocal gift. ${ }^{20}$ Shakespeare's first audiences were certainly conversant with the problem of how to express a gift in practical term, and whether this generosity could fail or even, perversely, become a demand. The events of the play project this everyday concern unto a vast canvas, where Anthony can "give a kingdom for a mirth" in Caesar's disgusted phrase (1.4.18). Nevertheless, this fictive world of diplomacy and power politics reflects the everyday world, of gifts given and received, of hospitality offered and accepted or refused. Indeed, the problem that the play poses remains with us today. We too must ask whether hospitality inevitably proves hostile, and struggle to imagine how a truer hospitality could be expressed in our lives without collapsing into politics in the sense of cynical manipulation and bids for power. We too must ask how to offer without threatening and how to receive without suspicion. Shakespeare's play depicts hospitality in an imperial political context and historiography of the early modern period places gifts in a local political context; both illustrate the tendency for hospitality in the radical sense used by Derrida and Levinas to decline into hospitality in the sense used by Mauss and Benveniste.

In the play, as in early modern societies and indeed our own, a radical hospitality must express itself in quotidian, political terms, and therefore run the risk of going wrong. Cleopatra's hospitality toward Thidias sends Anthony into a towering, torture-inflicting rage on the sight of "a fellow that will take rewards" being "familiar with / My playfellow, your hand" (3.13.124-126). This pattern of hospitality signifying the success or failure of relationships themselves extends beyond the relationship of the title characters. The play opens with Anthony's failure to greet Caesar's ambassadors, a failure that leads to the coldness of his meeting with Caesar later, where each of the rivals ignores the other and instead addresses a follower (2.2.22). When they do concede to face-to-face communication, Caesar's second complaint is that "When rioting in Alexandria you / Did pocket up my letters, and with taunts / Did gibe my missive out of audience" (2.2.76-78). This follows the complaint that Anthony's "wife and brother / Made wars upon me" (2.2.46-47) and precedes the complaint that "You have broken / The article of your oath" (2.2.85-86). Caesar may not consider a failure of 
hospitality to be as serious as waging war or violating a treaty, but manifestly lists it among such offenses. Throughout the play, welcomes show political allegiance, friendship, and erotic partnership, but they also threaten to fail, exposing the wrong relationship or disclosing a relationship's failure. Worse, they threaten to succeed too well, to convert a gift into a poison. They therefore elicit suspicion. Acts of hospitality and generosity show an unfortunate and paradoxical tendency to undermine rather than reinforce relationships.

The play's Roman and Egyptian worlds are separated not only by cultural difference and misunderstanding, but also and more obviously by the geographical distance across which characters communicate by messenger, sending embassies like that which Anthony ignores in the first scene. In three other early scenes Cleopatra hears of Anthony by way of a messenger after he returns to Rome. The first of these scenes establishes a pattern: Cleopatra greets Alexas, the messenger, ascribing to him some of Anthony's charisma and inquiring as to her lover's well-being. Anthony sends a message of love and expresses it with "[t]his orient pearl" (1.5.41). It may be ironic that Anthony, in Rome, sends a gift so overtly associated with the east to Cleopatra, in Egypt, but he also promises to "piece / Her opulent throne with kingdoms" (1.5.45-46). She, in turn, not only greets his messenger but determines to send Anthony "every day a several greeting" (1.5.77). The greetings at this point are reciprocal: moreover, the play hints that the gifts merely circulate, because the pearl both comes from the east and returns to it. In any case, expressions of love are clearly material. Whereas in the play's first scene Anthony protests that " $[\mathrm{k}]$ ingdoms are clay" and dismissively compares political responsibility to the expression of love (1.1.37), here kingdoms express love as extravagant gifts. Anthony gives more than he has, promising kingdoms he has yet to conquer, and which anyway would be conquered in the name of Rome. The same scene already shows cultural misunderstanding. Anthony presents himself by proxy as "the firm Roman," ascribing to himself a stoic calm identified with his national character (1.5.43). The next messenger scene shows that Anthony remains insufficiently firm in his commitment to Cleopatra to forgo marrying Octavia, so his self-description may be suspected of exaggeration, if not fraud. This hardly matters, however, because Cleopatra misunderstands Anthony's self-declared temperance, mistaking it for violently contradictory passion: "Be'st thou sad, or merry, / The violence of either thee becomes, / So does it no man else" $(1.5 .52,59-60)$. This scene presents a series of ceremonies of hospitality: Anthony's messenger is greeted, his master is greeted by proxy, the messenger greets Cleopatra, Anthony greets Cleopatra through the messenger, Anthony sends Cleopatra a gift, and Anthony promises more gifts. The scene also raises many of the worries that attend ceremonies of hospitality: the gift could constitute an attempt at manipulation, bribery, or even purchase; it might misrepresent the giver's commitment; and the entire transaction might illustrate the mutual incomprehension of its participants. 
The second messenger scene, in which an anonymous messenger replaces Alexas, parodies the first. Cleopatra offers gold, but only if the news is good:

But well and free,

If thou so yield him, there is gold, and here

My bluest veins to kiss, a hand that kings

Have lipped, and trembled kissing.

It is again ironic that she offers the same favor to which Anthony takes such violent exception when it is later given to Thidias. She also offers the messenger "[r]ich pearls," echoing Anthony's gift from the earlier scene (2.5.47). In this case, however, Cleopatra offers material rewards in an overt effort to control the news. When the messenger presents bad news anyway, Cleopatra attacks him and threatens him with death, though she also offers him "a province" to change it. She shows herself cruel as well as ignoble to strike the messenger, as she herself admits (2.5.83-85). More important, she exhibits a sort of irrationality, as though harming the messenger could change the message. Her irrationality nevertheless follows from the assumption justified by the earlier scene, that welcomes take material or political form. The material form of welcome tempts Cleopatra to conflate the welcome with its expression and then attempt to control one through the other, as if they were simply the same. The expression of hospitality threatens to displace hospitality itself.

Starting with Anthony and Cleopatra's first meeting, food constitutes an important expression of hospitality. Asking about Enobarbus's entertainment in Egypt, Mecenas retails a story about "[e]ight wild boars roasted whole at a breakfast" (2.2.186). In what is probably the best essay published on food in Anthony and Cleopatra, Peter A. Parolin argues that "food plays a crucial role in elucidating" all of the "central struggles of the play." ${ }^{11}$ Food has two obvious roles as a weapon: it can kill if withdrawn, but can also weaken through overindulgence. Parolin draws attention particularly to Philip Stubbes, who argues in his 1583 The Anatomy of Abuses against overindulgence in "dainty fare," ${ }^{22}$ though one might also think of attacks against particular foods even today (gluten, perhaps, or saturated fats). Hence Caesar's call on the absent and indifferent Anthony to "leave thy lascivious wassails," referring to his earlier survival of "[f]amine ... whom thou fought'st against" as a model of behavior "like a soldier" $(1.4 .56,59,70)$. More subtly, food can also function as a weapon by claiming reciprocation within an exchange of hospitality. A dinner invitation, like that of Cleopatra to Anthony, places both the recipient and the host under obligation. Feasting affirms relationship, but also simultaneously casts suspicion on the relationship, because the feast might be no more than an act of "antagonism and rivalry," to borrow the phrase with which Mauss describes First Nations potlatches. ${ }^{23}$ 
Cleopatra is repeatedly described not only as something consumable, but also as herself a consumer, possessed of ravenous appetites for food, drink, and sex. In her first scene after Anthony's return to Rome we find her exhibiting her desire for him- "O happy horse, to bear the weight of Anthony!" (1.5.21) — and her enjoyment of food amounts to a self-definition. "[S]ince my lord / Is Anthony again," she says, planning to feast on her birthday, "I will be Cleopatra" (3.13.186-187). Finally, she imagines death as a withdrawal from gustatory pleasure: "Now no more / The juice of Egypt's grape shall moist this lip" (5.2.280-281). "I drink," an Egyptian Descartes might say, "therefore I am." Mauss emphasizes the importance of presents of drink, but here the wine is not to be given but consumed. Cleopatra presents herself less as an object, a gift to be exchanged between men, than as a consumer.

Cleopatra both baffles and terrifies Anthony by her ability to rise above the status of a comestible. Karen Britland argues that "[e]xcess in the play is feminized, becoming conflated with the corrupting influence that Cleopatra and her Egypt have over Antony," ${ }^{24}$ but Cleopatra's excess distinguishes her from other women. In his description of her as "making hungry where most she satisfies," Enobarbus explicitly contrasts her to "other women" (2.2.243-245). Anthony may find himself drawn back to Cleopatra, but this mystifies him: "She is cunning past man's thought," he declares early in the play (1.2.145). He later accuses her of witchcraft (4.13.47). Cleopatra defies the treatment of women as consumable or exchangeable for two reasons: First, she is an Other, in fact a beloved. The Other, according to Levinas,

resists me with all his force and all the unpredictable resources of his own freedom. I measure myself against him. But he can also-and here is where he presents me his face-oppose himself to me beyond all measure, with the total uncoveredness and nakedness of his defenseless eyes, the straightforwardness, the absolute frankness of his gaze. ${ }^{25}$

Cleopatra does both. She resists reduction to the level of a consumable radically, by being the Other, the beloved. Even when comparing her to food, Enobarbus describes her paradoxically, as a food that increases hunger. Though Levinas does not cite Anthony and Cleopatra, the play anticipates his description of metaphysical desire, which he contrasts in Totality and Infinity with a desire capable of satisfaction: "Besides the hunger one satisfies, the thirst one quenches, and the senses one allays, metaphysics desires the other beyond satisfactions." ${ }^{26}$ In one of his first essays of an independent philosophy, he asks his reader to "[c]ompare eating to loving, which occurs beyond economic activity and the world." ${ }^{27}$ Cleopatra resists reduction to the status of food, of object, simply by being the beloved, who stands over and against Anthony as an appeal rather than as an opponent.

Second, Cleopatra resists reduction to an object of consumption in practical terms, by the hospitality with which she imposes a burden of response on Anthony. Britland shows how "she is both the active agent that is to 
encourage Antony's feasting, and the passive object that he will consume."28 On the River Cydnus, she presents herself as an object of admiration, at least, to Anthony. Enobarbus's claim that "she pursed up his heart" implies, however, not that she becomes Anthony's object, but that her magnificent self-presentation makes him hers. Her earlier self-presentation to Julius Caesar "in a mattress" makes an overt offer of her self and body, but unlike Octavia, she retains power in her relationships (2.6.71). She avoids becoming an object exchanged by men by giving herself. In Mauss's play on words, she offers a gift-herself - that can be suspected of being a poison. To return to the double meaning explored by Benveniste, she plays host, but thereby becomes something of a threat, if not quite an enemy.

Perhaps the feast on Pompey's ship furnishes the best example of hospitality simultaneously constructing and undermining a relationship. Honor forbids Pompey from killing his guests, the triumvirs. He explains this to Menas in response to the suggestion that he do just that:

Ah, this thou shouldst have done,

And not have spoke on't: in me 'tis villainy;

In thee 't had been good service. Thou must know,

'Tis not my profit that does lead mine honour;

Mine honour, it.

Pompey's explanation, however much it fails to appeal to us, shows that the code of hospitality that he follows possesses all the complexity of a cultural belief system, placing him under an obligation that he respects to his mortal cost. More to my point, Pompey would avoid this obligation, wishing Menas had slit the throats of the drunken triumvirs before asking, because Menas is not the host and therefore not under obligation himself. In fact, as a recipient of Pompey's patronage, Menas would be performing "good service" (2.7.76). Menas himself offers generosity, boasting to his patron that "though thou think me poor, I am the man / Will give thee all the world" (2.7.65-66). When Pompey refuses, Menas dismisses him with a proverb as ungrateful: "Who seeks and will not take, when once 'tis offered, / Shall never find it more" (2.7.83-84). Hospitality in the play neither appears in a pure, radical form, nor decays into pure cynicism. Rather, it maintains its claims even while being expressed in and perhaps betrayed by social conventions. Pompey respects the ceremonies and obligations of hospitality, refusing to kill his guests, but does not extend them hospitality in the radical sense Derrida finds in Levinas, welcoming the Other. Pompey's refusal to kill the triumvirs combines with his wish that Menas had, to show the paradoxical force of hospitality as Mauss understands it, both sealing friendship and rendering it antagonistic. Pompey attempts to overcome his distrust of Anthony by partying with him: "O Anthony, / You have my father's house. But what, we are friends?" (2.7.126-27). Events fully justify whatever anxiety the folio's 
question mark indicates, because Pompey is soon displaced, albeit by the sober Caesar. Britland argues that the feast onboard Pompey's ship succeeds in achieving conviviality through its exclusion of the feminine. ${ }^{29}$ The situation is indeed strikingly all-male, if not positively homoerotic, ending with Enobarbus and Menas going off to bed together and incorporating an allmale dance to the singing of a boy. Nevertheless, the conviviality depends on the humiliation of a drunken Lepidus, and Caesar clearly does not enjoy himself: "It's monstrous labour when I wash my brain, / An it grows fouler" (2.7.96-97). Whatever alliance is achieved under these unpromising conditions disappears with the hangovers. Caesar disposes of first Pompey and then Lepidus almost as soon as all three can get offstage. While hospitality in the radical sense (as Saying) might take the form of rules and rituals (the Said), these rules and rituals signally fail to generate a true welcome. On the contrary, the exchanges by which the triumvirs seek to maintain their alliance take place within a world of power struggles and are, therefore, always already suspect. Drinking together can express the loyalty of the triumvirs, but as an unstable sign, it can also falsely express a loyalty that simply is not there. More to the point, it can no more generate loyalty than Cleopatra's elaborate donations to the messenger can change the news.

What Aufidius in Coriolanus calls "the hospitable canon" 30 guards Pompey against Caesar's ambition no better than it guards Coriolanus against Aufidius's followers, or for that matter, than Lear's division of his kingdom between his daughters guards the old king against homelessness. Rituals of hospitality should not be ignored, however, even though they fail to inspire the sort of affection that at least some of their participants wish. Anthony and Caesar each protests that the other has violated his bond. Anthony nevertheless refuses to ignore Caesar's accusation, for, as he tells Lepidus, "[t]he honour is sacred which he talks on now" (2.2.90). As statesmen, the Romans operate in power relations, but they do not nihilistically embrace the pursuit of power as a total goal. Neither Anthony nor Caesar disregards his own word; on the contrary, both attempt to reinforce their alliance by the exchange of a woman, Octavia. This alliance, moreover, depends on real affective relationships. Caesar gives Anthony, as he specifies, "a great part of myself," indeed the only blood relative he is shown to have in the play (3.2.24). Agrippa's plan for the strategic marriage depends heavily on the two competitors' mutual affection for Octavia, "To make you brothers, and to knit your hearts / With an unslipping knot" (2.2.132-133). The idea of building relationships between men through the exchange of a woman is almost a cliché of both anthropology and early modern diplomacy, but the play emphasizes how much it depends on both men actually loving Octavia. Nevertheless, as Enobarbus accurately predicts, "the bond that seems to tie their friendship together will be the very strangler of their amity" (2.6.119-121). Inevitably, the treatment of Octavia becomes one of the causes of the civil war. "[T] he high gods, / To do you justice, makes his ministers / Of us and those that love you," explains her brother, filled with pious fraternal loyalty 


\section{2}

\section{Sean Lawrence}

(3.6.88-90). ${ }^{31}$ Even in its violation, the bond between Anthony and Caesar reveals its reliance on the radical claims of hospitality, as does Pompey's decision to follow his culture's code of hospitality. If Caesar had no affective ties to Octavia, then he would have less cause to go to war and, earlier, would be offering Anthony a gift of no value, inadequate to seal their alliance. Like the relationship of the title characters, that between the two principal triumvirs for control of the ancient world does not simply devolve into a cynical, cold, or calculating exchange. Their relationship takes the form of a particular cultural practice well documented by history and anthropology, and also relies on "ethicity itself," which Derrida identifies with the radical hospitality described by Levinas. As an expression and application in social forms of such hospitality, however, it remains open to the suspicion of being not only a lie, but also and more damningly, a cynical and threatening bid for power.

The Roman culture of stoicism produces Anthony, whereas Cleopatra rules and personifies Egypt, a world of epicureanism, self-indulgence, and love. Both title characters, however, find themselves locked in a power struggle, the exigencies of which apply to both worlds. Cleopatra wages love like Anthony wages war. "If it be love indeed," Cleopatra demands with her first line, "tell me how much" (1.1.14). The lovers already exchange claims of affection, competitively, as they will soon exchange gifts to signify this love. Cleopatra implies that Anthony is subordinate to "the scarce-bearded Caesar" or perhaps "the shrill-tongued Fulvia" $(1.1 .22,34)$. Cleopatra forces Anthony to defend himself against the emasculating implication of being ruled by a woman, thereby herself ruling him, ironically or perhaps just hypocritically. Anthony's response_- "Let Rome in Tiber melt" (1.1.35)—provides her a tactical victory, because he rejects Rome in favor of her, though she soon reverses her position, demanding that he "[h] ear the ambassadors" (1.2.50). The manipulation is trivial; Anthony can always hear the message later, and a delay does not change the news. The breadth of Anthony's negligence regarding Roman politics, however, shows that Cleopatra makes a habit out of such manipulation. From the messenger's report in the second scene, it appears that Anthony has missed three wars altogether (1.2.88-104). Prospero on his island could not be farther out of touch. More important, Cleopatra shows her determination to thwart Anthony's desires, keeping him beholden to her, in her rejection of Charmian's advice to " $[\mathrm{t}] \mathrm{empt}$ him not so far" (1.3.11). Part of Cleopatra's "infinite variety" is inconsistency, even perversity. "If you find him sad," she instructs Charmian, "Say I am dancing; if in mirth, report / That I am sudden sick" (1.3.3-5). "You have been a boggler ever," Anthony exclaims, with understandable exasperation (3.13.111). Cleopatra never surrenders herself to Anthony. Because women in Rome are exchanged between men when not dismissed as trivial pleasures by the likes of Enobarbus, she is no doubt wise to maintain her power in the relationship. The result of her strategy, however, is that until very late in the play, all Cleopatra's hospitality to Anthony-her welcome of him into 
her kingdom, her bed and, when he sires her children, her body-may be suspected of being part of an effort to control him.

Cleopatra has reason to control Anthony, needing his military power at least as much as the other triumvirs need him to fight Pompey: "That Herod's head / I'll have-but how, when Anthony is gone, / Through whom I might command it?" (3.3.4-7). Her one disastrous attempt at tactical command during the battle of Actium shows how completely she relies on Anthony's military skill. Even her retreat from Actium keeps Anthony dependent, because he is unable to conclude the civil war in victory, return to Rome, and forget her. One admires her ability to assert herself as "the president of my kingdom" (3.7.17) in so masculine a world. Cleopatra does not create the world in which power corrupts love; she merely flourishes in it. Cleopatra's hospitality should be placed among the other practices of competitive hospitality in the play, and indeed, of the power relations tearing apart the Roman world. She assumes the position of an agent and a host, but her hospitality elicits the suspicion-of Anthony and of generations of critics-that she is merely manipulative.

Cleopatra seldom praises Anthony to his face. Before he first leaves for Rome, she accuses him of faithlessness to Fulvia (1.3.62-65), betrayal to herself (1.3.24-25), dishonesty (1.3.37-39), and drama-king hyperbole (1.3.82-85). She indulges in emasculating claims about what would happen if "I had thy inches" (1.3.40). She nominates him "the greatest soldier of the world" but only in order to claim that he has "turned the greatest liar" (1.3.38-39). Once he is safely off-stage, however, she compares him favorably to Julius Caesar and calls him "[m]y man of men" (1.5.72). She inflates him into a colossus after his death:

His legs bestrid the ocean; his reared arm Crested the world; his voice was propertied As all the tunèd spheres-and that to friendsBut when he meant to quail and shake the orb, He was as rattling thunder.

Her praise of him reaches a crescendo in a sort of ontological proof for Anthony's existence: "It's past the size of dreaming" (5.2.97). Cleopatra lavishes fulsome praise on her lover, but not to his face. To do so would render herself less powerful in the relationship, admitting, as she in fact does after his death, that she is "commanded / By such poor passion as the maid that milks / And does the meanest chores" (4.6.74-76). Cleopatra deploys pastoral imagery, but with the effect of identifying herself with the most powerless members of her sex. Whereas Marlowe's passionate shepherd promises luxury and entertainment, Cleopatra imagines only demeaning labor and servility. Cleopatra seldom admits her love, and even less to Anthony's face, lest it render it abject. 
The process of Anthony and Cleopatra's destruction takes the form of expanding their exchanges of hospitality from the dueling invitations with which their wooing began on the River Cydnus into a vortex that consumes the eastern Mediterranean and then themselves. Their reciprocal donations constitute a potlatch more extreme than anything dreamt of by anthropology. As Caesar reports in disgust, "Unto her / [Anthony] gave the stablishment of Egypt, made her / Of lower Syria, Cyprus, Lydia, / Absolute queen" (3.6.8-11). Later, Anthony chooses to fight at sea, placing himself in Cleopatra's power, but also allowing her to provide him "sixty sails" (3.7.49). This may not be as reckless as it appears. Anthony fully intends to fight a second battle on land, should the naval engagement prove unsuccessful (3.7.52-53). The plan fails in the only way in which it could, when Anthony compounds defeat at sea with such utter disgrace that his land forces abandon him in disgust. In the next scene, he actually encourages his followers to desert, magnificently providing them "a ship, / Laden with gold" (3.11.4-5), before blaming Cleopatra for his loss. He nevertheless cites his disgrace as an overwhelming proof of his love for her: "thou knew'st too well / My heart was to thy rudder tied by th'strings, / And thou shouldst tow me after" (3.11.55-57). Having forced her to ask "Pardon, pardon!" he accepts a single kiss in repayment, literalizing Scarrus's appalled metaphor in the previous scene: "[W]e have kissed away / Kingdoms and provinces" $(3.11 .72 ; 3.10 .7-8)$. Anthony loses the battle of Actium, but gains the upper hand in his relationship with Cleopatra. His flight from battle may be seen as an effort to answer Cleopatra's opening question: "If it be love indeed, tell me how much" (1.1.14). The answer is that Anthony loves Cleopatra so much that he will give up victory, the empire, his followers, and even his self-respect. Like an extravagant host, Anthony gives everything he owns, though also like an extravagant host, he may be suspected of only seeking to impose a burden of reciprocation.

Suicide might be taken as an even more extreme effort to answer the question of "how much" love would constitute "love indeed." After the naval defeat at Alexandria, Anthony determines again that Cleopatra "[1]ike a right gypsy hath at fast and loose / Beguiled me to the very heart of loss" (4.13.28-29). In order to restore his love and trust, Cleopatra sends the lie that "I have slain myself" (4.14.7). Even she recognizes the risk inherent in this plan. Diomedes recalls that "[s]he had a prophesying fear / Of what hath come to pass" (4.15.121-122). Her reckless plan is in keeping, however, with other efforts to elicit obligation by donation, up to and including self-destruction. Besides, her plan works, only not in the manner she hopes. On hearing of her feigned death, Anthony declares that "I will o'ertake thee, Cleopatra, and / Weep for my pardon" (4.15.44-45). After Anthony's actual if maladroit suicide, Cleopatra decides to kill herself "after the high Roman fashion" (4.16.88), thereby claiming him as her husband: "Now to that name my courage prove my title!" (5.2.287). Rather than working together to defeat their common enemies, the title characters lay claims upon one 
another. The exchanges that reinforce their relationship must always grow larger, because the lovers' claims on each other appear mutually threatening. As a result, the whole play becomes a desperately inflated effort to answer Cleopatra's opening question.

Moreover, no response to Cleopatra's demand to know "[i]f it be love indeed, ... how much," can silence the doubt it expresses, because the sorts of exchanges into which the characters enter can never shake the suspicion of being mere efforts at control. No number of losses by Anthony can make enough of a claim on Cleopatra to entirely ensure him of her loyalty. In what is perhaps Anthony's most convincing statement of love, he explains to the significantly named Eros that "I made these wars for Egypt, and the Queen-/ Whose heart I thought I had, for she had mine / ... has / Packed cards with Caesar" (4.15.15-19). In the context of Anthony's rants, the words "Whose heart I thought I had, for she had mine," each monosyllabic and Anglo-Saxon, produce a statement of great simplicity and candor. While these lines make eloquent expression of his love, however, they also show Anthony murderously suspicious regarding Cleopatra's.

As already noted, Thidias's display of courtly manner rouses Anthony to fury. Before Anthony comes onstage in this scene, Cleopatra places herself under the control of Caesar at least rhetorically, while claiming that her earlier affair with Anthony was forced: "Mine honour was not yielded, / But conquered merely." It is of course possible to find a reading of Cleopatra's actions in this scene that remains charitable to her. The sentence just quoted is immediately preceded by the hyperbolic claim that Caesar "is a god, and knows / What is most right" (3.13.60-62). Hyperbole often implies irony, and the first sentence in this speech might ascribe the view expressed in the second to Caesar. In answer to Thidias's claim that "he knows that you embraced not Anthony / As you did love, but as you feared him," Cleopatra replies with a neutral monosyllable, "O" (3.13.56-57). A few lines earlier, Enobarbus greets Thidias with an elaborate but equivocal claim of loyalty to Caesar, built on the argument that Enobarbus is a follower of Anthony, himself willing to be a friend to Caesar (3.13.50-52). Cleopatra may make similarly equivocal or at least noncommittal gestures. Indeed, nowhere in the scene does Cleopatra in fact promise to surrender Anthony, though she also does not refuse. Rather the scene shows Cleopatra deploying careful diplomatic language. Thidias's kiss of her hand reverses her claim to Caesar that "I kiss his conqu'ring hand," while also respecting her abiding royalty (3.13.75). Cleopatra uses the occasion to recall her earlier sexual and political alliance with Caesar's father, and hence open the possibility of a renewed familial bond. Parolin credits Cleopatra with "culinary diplomacy" in her wooing of Anthony, and one might see her making a similar effort here, as Anthony himself recognizes in referring to Thidias as "a feeder." According to Parolin, this is an attack on Thidias's "social standing as a subordinate who eats what his master supplies," 32 but it also relates Thidias's gesture in kissing Cleopatra's hand to the hospitality with which she offers herself 
to Anthony in their initial dinner invitations. All such careful maneuvering, however, is tossed aside by Anthony's certainty: "Favours, by Jove that thunders!” (3.13.85). He replaces Cleopatra's studied ambiguity with straightforward violence: "Whip him, fellows, / Till like a boy you see him cringe his face / And whine aloud for mercy" (3.13.99-101). One can make an argument in favor of Cleopatra's ambiguity over Anthony's simple and furious clarity, but it is Cleopatra's ambiguity that invites Anthony's response. Both subtlety and literalism rely on interpreting signs of hospitality. We can accuse Anthony of a coarse semiotics, but it is very difficult to tell from what Anthony sees-the tableau of Thidias kissing Cleopatra's hand-whether Cleopatra flatters Caesar while remaining loyal to Anthony or abandons Anthony in favor of Caesar. Hospitality, in the sense of rituals of welcoming, indicates Cleopatra's loyalty throughout the play, so her hospitality to Thidias appears to make a new claim of loyalty, this time to Caesar. The situation calls for interpretation, but more important, it calls for interpretation within a context where hospitality may be hostile. Anthony finds his fears being realized before his eyes and responds not with mere confusion or even disgust, but with destructive rage. The queen temporarily overcomes Anthony's distrust by another offer:

From my cold heart let heaven engender hail, And poison it in the source, and the first stone

Drop in my neck: as it determines, so

Dissolve my life; the next Caesarion smite,

Till by degrees the memory of my womb,

Together with my brave Egyptians all,

By the discandying of this pelleted storm,

Lie graveless, till the flies and gnats of Nile

Have buried them for prey.

Naseeb Shaheen finds in this passage three separate references to the plagues of Egypt described in Exodus. ${ }^{33}$ As an assurance, Cleopatra calls down a Biblical plague, offering her life, her progeny, and the population and survival of the kingdom with which she identifies. Anthony and Cleopatra raise the stakes of their relationship by making greater and greater offers, but these provide only temporary reassurance.

Their hospitality extends to the metaphysical, giving each other opportunities to assume divinity and imagine a glorious afterlife. Caesar reports in disgust that Cleopatra assumes "th'habiliments of the goddess Isis" (3.6.17). When to everyone's surprise Anthony sends Enobarbus his personal fortune, this proves that "[y]our Emperor / Continues still a Jove" (4.6.26-27). Retrospectively deifying her lover, Cleopatra claims that "realms and islands were / As plates dropped from his pocket" (5.2.91-92), making him infinitely and impossibly generous. ${ }^{34}$ William Flesch notes that Anthony's generosity 
is always excessive, especially when he has nothing to give and even his god has abandoned him. ${ }^{35}$ Rather than depending on a divine patron, Anthony wishes to become an all-giving god himself. However, the play contains a good deal of evidence that he is not even a particularly good soldier, never mind, as Cleopatra extravagantly describes him early in the play "a Mars" (2.5.118). Ventidius observes that "[h]e and Caesar have ever won more in their officer than in their person" (3.1.16-17). Though he wins few battles, Anthony can nevertheless take the role of Mars in Cleopatra's arms, especially if he accepts her self-presentation as Venus on the River Cydnus at their first meeting, surrounded by "pretty, dimpled boys, like smiling Cupids," and "[o]'er-picturing that Venus where we see / The fancy out-work nature" (2.2.207-209). Perhaps more convincingly, "the holy priests / Bless her when she is riggish" as they would the goddess of sex (2.2.246-247). Conversely, although "wrinkled deep in time," Cleopatra can assume the place of Venus by loving her Mars (1.5.29). Both Cleopatra's memory of cross-dressing an unconscious Anthony (2.5.23-24) and his arming before the battle of Alexandria (4.4) imply a parallel with imagery of Mars and Venus. ${ }^{36}$ Anthony, for his part, attempts to incarnate war, promising to violate all rules of chivalry: "I'll set my teeth, and send to darkness all that stop me" (3.13.181-182). Shakespeare's most famous ancient lovers attempt to raise themselves to the divine. By doing so, they ratify Anthony's claim that, to "set a bourn how far to be beloved," Cleopatra must "find out new heaven, new earth" (1.1.16-17). Having given each other kingdoms, heirs, and even their own lives, they also attempt to give each other divinity.

Of course they fail. Anthony replies to Cleopatra's demand to know "how much" he loves her by declaring that "[ $t]$ here's beggary in the love that can be reckoned" (1.1.15). There is also a sort of category error in trying to count love, as if it were a form of wealth or territory, as though it were to be expressed in ever more extravagant gifts. The characters attempt to give each other glorious afterlives, but this merely extends into eternity the very structure that dooms their relationship to murderous anxiety. From a Christian perspective, especially the Reformed perspective taking shape in Shakespeare's England, unearned Grace would correspond to a radical gift of hospitality, a welcoming into heaven that is asymmetrical and extraordinary, but these pagan characters prove unable to imagine it. Indeed, their imagery suggests failure as much as celestial success. They picture themselves as Venus and Mars, but their role models' adulterous relationship terminates in embarrassment when the lovers are revealed to all the gods, "with shame inough fast lockt togither." 37 "Dido and Aeneas," says Anthony as he plans suicide, "shall want troops" (4.15.53), but Aeneas abandons Dido to found Rome, as Christopher Marlowe and Thomas Nashe show in Dido, Queen of Carthage, and Virgil's Dido rejects Aeneas when they meet in the underworld in book 6 of the Aeneid. In an article first presented in the early 1970s, Levinas argues that even the Apollo astronauts did not find a true elsewhere, but only a continuation of the same. ${ }^{38}$ Attempting to "find out 


\section{8}

new heaven, new earth," the lovers of Shakespeare's play only extend the power struggle that defines their own world toward ever-receding horizons. They do not truly open themselves to each others' alterity or even to the alterity of death.

Shakespeare's protagonists may begin with Saying, with an extraordinary hospitality, a welcome of each other as Other, but the expression of their love moves it into the Said. Their acts of hospitality all suffer the instability of the sign: no one can tell what Anthony means by the gift of the pearl or even if he offers it in good faith; neither the on-stage nor the off-stage audiences can tell what Cleopatra means by allowing Thidias to kiss her hand; Cleopatra's death may show her loyalty, but her first claim to have died merely manipulates; Anthony accepts the offer of Cleopatra's navy, but he may be merely testing her continued loyalty. At least as important, Anthony and Cleopatra's acts of hospitality imbricate them in competitive donation. Beginning with their first dinner, their exchanges spiral out of control like a parody of the ceremonies Mauss describes, extending from absurdly elaborate meals to kingdoms, lives, and otherworldly myths. Rather than providing security in their trust in one another, every donation stakes a threatening claim. Derrida continues his discussion of the impossibility of building a practical politics on the foundation of Levinas's theory of hospitality by asking "Does this impossibility signal a failing? Perhaps we should say the contrary." ${ }^{39}$ Hospitality, in the Levinasian sense, may not realize itself in a clear political expression. Attempts to give such hospitality political form, I have argued, merely betray it into the competitive exchanges that constitute hospitality in the Maussian sense. By its very contrast, however, Levinasian hospitality allows a judgment of Maussian hospitality as a whole. We can ask whether Shakespeare's title characters truly welcome each other and critique their efforts; more generally, we can critique our own ceremonies and acts of hospitality, and call upon ourselves to welcome the Other more fully and generously.

\section{Notes}

1. William Shakespeare, The Tragedy of Anthony and Cleopatra, ed. Michael Neill (Oxford: Clarendon, 1994), 2.2.226-229. Future citations of the play will be to this edition, and indicated in parentheses. I am following this text in the spelling of Anthony's name.

2. Oxford English Dictionary, s.v. "Ordinary," accessed February 11, 2015, http:// www.oed.com/view/Entry/132360.

3. Jacques Derrida, Adieu: To Emmanuel Levinas, trans. Pascale-Anne Brault and Michael Naas (Stanford: Stanford University Press, 1999), 18, 57, 142n58.

4. Marcel Mauss, "Gift, Gift," in The Logic of the Gift: Toward an Ethic of Generosity, ed. Alan D. Schrift (New York: Routledge, 1997), 29-30.

5. Émile Benveniste, "Gift and Exchange in the Indo-European Vocabulary," in The Logic of the Gift: Toward an Ethic of Generosity, ed. Alan D. Schrift (New York: Routledge, 1997), 33.

6. Ibid., 38 . 
7. To be fair, Shakespeare's major source, Plutarch, also makes no mention of this event. The parallel with Hamlet, however, would seem to indicate that the playwright had at least heard of it; William Shakespeare, Hamlet, ed. G. R. Hibbard (Oxford: Oxford University Press, 1987), 5.2.219-221. For the history, historiography, chemistry, and even gastronomy of the anecdote about Cleopatra swallowing a pearl, see Berthold L. Ullman, "Cleopatra's Pearls," The Classical Journal 57, no. 5 (February 1957), 193-201.

8. Derrida, Adieu, 18. Derrida is writing here specifically of Levinas's philosophy of teaching, which emphasizes its generosity.

9. Sean Lawrence, Forgiving the Gift: The Philosophy of Generosity in Shakespeare and Marlowe (Pittsburgh, PA: Duquesne University Press, 2012), 14-18.

10. Derrida, Adieu, 21, 25.

11. Ibid., 50.

12. Ibid., 20-21.

13. Ibid., 75 .

14. He agrees with Jean-Luc Marion's observation to this effect in Autrement que Savoir: Emmanuel Levinas (Paris: Editions Osiris, 1988), 75.

15. Emmanuel Levinas, Ethics and Infinity, trans. Richard A. Cohen (Pittsburgh, PA: Duquesne University Press, 1985), 88. Neither Levinas nor his various translators and editors are consistent in capitalizing "Saying" and "Said." I have capitalized these words outside quotations to draw attention to their specialized use.

16. Emmanuel Levinas, "Diachrony and Representation," in Time and the Other and Additional Essays, trans. Richard A. Cohen (Pittsburgh, PA: Duquesne University Press, 1987), 103.

17. Emmanuel Levinas, Otherwise than Being, or Beyond Essence, trans. Alphonso Lingis (Pittsburgh, PA: Duquesne University Press, 2000), 6.

18. Felicity Heal, "Hospitality and Honor in Early Modern England," Food and Foodways 1 (1987), 325.

19. Natalie Zemon Davis, The Gift in Sixteenth-Century France (Madison, WI: Wisconsin University Press, 2000), 11-12.

20. Ibid., 99, 114-15.

21. Peter A. Parolin, "'Cloyless Sauce': The Pleasurable Politics of Food in Antony and Cleopatra," in Antony and Cleopatra: New Critical Essays, edited by Sara Munson Deats (New York: Routledge, 2005), 213.

22. Ibid., 214.

23. Marcel Mauss, The Gift: The Form and Reason for Exchange in Archaic Societies, trans. W. D. Halls (New York: W. W. Norton, 1990), 37.

24. Karen Britland, "Circe's Cup: Wine and Women in Early Modern Drama," in A Pleasing Sinne: Drink and Conviviality in Seventeenth-Century England, ed. Adam Smyth (Cambridge: D. S. Brewer, 2004), 118.

25. Emmanuel Levinas, "Philosophy and the Idea of the Infinite," in To the Other: An Introduction to the Philosophy of Emmanuel Levinas, ed. Adriaan Peperzak (West Lafayette, IN: Purdue University Press, 1993), 109-110.

26. Emmanuel Levinas, Totality and Infinity: An Essay on Exteriority, trans. Alphonso Lingis (The Hague: Martinus Nijhoff, 1961; reprint, Pittsburgh, PA: Duquesne University Press, 1969), 34.

27. Levinas, Existence and Existence, trans. Alphonso Lingis (The Hague: Martinus Nijhoff, 1978), 35.

28. Britland, "Circe's Cup," 119. 
29. Ibid.

30. William Shakespeare, The Tragedy of Coriolanus, ed. R. B. Parker (New York: Oxford University Press, 1994), 1.11.26.

31. The Oxford text replaces the folio's "Gods" with the singular "god," implying an anachronistic monotheism.

32. Parolin, “'Cloyless Sauce,” 220.

33. Naseeb Shaheen, Biblical References in Shakespeare's Tragedies (Newark: University of Delaware Press, 1983), 181-2.

34. Ibid., 223.

35. William Flesch, Generosity and the Limits of Authority: Shakespeare, Herbert, Milton (Ithaca, NY: Cornell University Press, 1992), 193, 222.

36. One thinks immediately of Sandro Botticelli's painting of Venus and a disarmed, exhausted, postcoital Mars.

37. Publius Ovidius Naso, Metamorphoses, trans. Arthur Golding, in the Perseus Digital Library, http://data.perseus.org/texts/urn:cts:latinLit:phi0959.phi006. perseus-eng2 (accessed June 19, 2014), 4.190.

38. Emmanuel Levinas, "Ideology and Idealism," in The Levinas Reader, ed. Seán Hand (Oxford: Blackwell, 1989), 241.

39. Derrida, Adieu, 20. 


\section{Part III \\ Script}


This page intentionally left blank 


\title{
6 Ave Desdemona
}

\author{
David Hillman
}

There is no salut that saves or promises salvation. -Jacques Derrida ${ }^{1}$

Greetings and leave-takings are key moments in every hospitality event, moments that encapsulate the paradoxes of hospitality as a whole-its ambivalence and equivocations, its generosities and power plays, its profound tensions between amity and enmity, openness to the other and selfassertion, servility and mutuality, improvisation and calculation. The first and last moments of an encounter can be transformational, acutely charged with the usually unspoken potentialities of what two (or more) people can do to, and with, each other. Salutations also manifest hospitality as dramaturgy: both theater and hospitality are structured around entrances, exits, and the forms of gesture and speech that they afford; opening gambits and parting shots help to set the tone for an encounter or to sum up what has just passed; they give it a dramatic frame. In this essay I wish to interrogate one particular moment of greeting that dances around the difficulties of hospitality, and in particular an aspect of hospitality not, to my knowledge, very often discussed: the question of what happens in the absence of the directness intrinsic to any ethics of hospitality-the immediacy of engagement without which hospitality is emptied of meaning. Othello, I suggest, addresses the dangers of mediation, of what takes place when what Emmanuel Levinas calls "the dual of the face to face, the singular welcome of the unicity of the other" is shunned. ${ }^{2}$ My essay approaches this by examining a single, curious instance of greeting in the play-Cassio's elaborate flourish upon the arrival of Desdemona in Cyprus: "Hail to thee, lady! and the grace of heaven ..." (2.1.85ff). ${ }^{3}$ As has often been noted, this salutation invokes the Ave Maria-a paradigmatic instance in Western culture of the greeting of the other as constitutive of their subjectivity. Cassio's Ave, both in its avoidance of Levinas's "uprightness of the welcome made to the face," 4 and in evoking the idea of Mary as mediatrix, alerts us to a crucial feature of Othello: the role of intercession in the downfall of all the play's protagonists. It is, I argue, through turning away from the immediacy of the engagement so important to hospitality that the play moves inexorably toward tragedy. 
The word greet derives from the Old Germanic grottjan, about which the Oxford English Dictionary tells us that "the senses of early occurrence in continental Germanic are 'to approach,' 'to call upon,' 'to provoke or compel to action,' 'to attack,' 'to irritate, annoy,' and 'to address, salute.'” It thus bears close parallels to what Derrida describes as the "self-contradiction," the "troubled and troubling origin" of the word hospitality-incorporating as it does both friendliness and hostility, greeting, and grating upon. ${ }^{5}$ Greetings (and partings) can function as provocations, challenges, demands, wishes, prayers, dismissals, and empty formulae, practicalities. The various conventional niceties and rituals of salutation help to structure and defuse the charged early moments of an encounter. They are designed to assuage anxiety, to smooth over or ward off the latent dangers inherent to transitional moments, turning away from any potential violence or sexuality. This is one of the reasons why the words accompanying these ceremonies of safety are almost all words of well-wishing, hopes and prayers for good health or safety, expressions of support or peace: pax vobis, I bring peace to you, not enmity. It also partially explains the frequency of invocations of divinities in salutations-god buy ye (the origin of good-bye), Godspeed, godden, adieu, and so on. And the desire to assuage anxiety also informs most of the traditional gestures of greeting and parting — bows, kisses, handshakes, embraces; these are in essence messages of peace, tentative nonaggression pacts and symbolic sublimations of aggression or sexuality (I kiss you rather than bite you; shake your hand rather than my fist, or spear; embrace you rather than squeeze the life out of you-or indeed leave you alone). The moment of meeting or parting involves first and foremost the establishment of a relation between bodies, a tactful/tactile interface of surfaces (grôtjan ultimately appears to derive from "the Germanic root "grôt- ..., an extension of the root which appears in Greek as $\chi \rho Y$ with the sense 'to approach closely, touch"”6). When one embraces, kisses, shakes hands, or even waves at the other, first and foremost one is sharing one's body with the other-sharing one's being-body, vulnerable and finite, with the vulnerable and finite other.

Connectedly, if more mundanely, salutations work to establish or at least confirm hierarchy or social rank; they ascertain belonging or nonbelonging to a given community, as well as degrees of intimacy or closeness within that community. And, while much here is pre-scripted (based on context, gender, age, status, and the like) and can be more or less taken for granted, a good deal remains up to the local nuances of a situation. (Indeed, this negotiation is the essence of tact; as Adorno writes, it is "the reconciliation-actually impossible- between the unauthorized claims of convention and the unruly ones of the individual" that constitutes tact, which "is the discrimination of differences"). ${ }^{7}$ There are minute decisions to be made all the time, delicate spatial and temporal calibrations: Is it going to be a handshake or have we graduated to a hug or a kiss? Who decides-who extends the hand first, what is the moment juste to lean forward for the kiss or to raise oneself up from the bow or curtsy? (This is why these moments are so frequently so awkward.) 
These are decisions with a dramaturgic component; and one is often halfaware of the scripted and performative aspect of greetings and partings, of an odd sense of being observed at these junctures-observed, and compared: the gradations of one's greeting or parting are always set in relation to those of others.

Salutations are thus an important part of what Aufidius calls "the hospitable canon" (Coriolanus, 1.11.26) ${ }^{8}$ yet they tend to pass under the critical radar because they are apparently so unremarkable—ordinary, if perhaps modish, formalities, ornamentations to get past so that one can engage with the meat of the encounter. As Hamlet puts it, "th'appurtenance of welcome is fashion and ceremony" (Hamlet, 2.2.372-373): that which belongs to (or is supplementary to) welcome is implicitly mere (passing) fashion and (formulaic) ceremony. Like a well-placed "comma 'tween their amities" (5.2.43), a well-executed salutation is meant to go unnoticed. But the (linguistic and gestural) rhetoric of greetings and partings was far from being overlooked in Renaissance England, where we find these ceremonies frequently commented upon: deployed extensively and self-consciously, and critiqued as hyperbolical or unnecessary or overelaborate. That Theseus can make fun of his underlings' intentions to "greet [him] with premeditated welcomes" (A Midsummer Night's Dream, 5.1.94), or that Goneril refers disparagingly to France's "compliment of leave-taking” (King Lear, 1.1.292) only underlines the point: these mini-ceremonies may be easily dismissed or ridiculed, but they are noticed. The period from, say, Erasmus's pedagogical writings to the end of the seventeenth century witnessed a heightened alertness to the significance of these formulae. One can see this, for example, in the conduct (and letter-writing) manuals: Erasmus's Colloquies-one of the formative pedagogical texts of early modernity-begins with pages upon pages of precepts and examples of greetings and partings; a glance at the enormous variety and subtlety of possible greetings and farewells such as that we find in Angel Day's English Secretarie is revealing. It is also visible in the period's travel literature, which often defamiliarizes norms of greeting and parting by drawing a contrast between the overelaborate gestures and empty rhetoric of European salutations, and the more straightforward or honest greetings and partings of other cultures; or in numerous theological tracts, to which I'll return in a moment.

As just one telling indicator of the heightened attention paid by early modern people to salutations, take the emphasis placed by the Quakers on abjuring the formalities of greeting. The men and women who rejected what they called "idle, foolish, good-for-nought, Ceremonious Salutations," in the name of both a disavowal of hierarchy and a sort of emotional purity, were regularly derided, beaten, fined, and imprisoned for their refusal to conform:

O the rage and scorn, the heat and fury that arose! Oh, the blows, punchings, beatings, and imprisonings that we underwent for not putting off our hats to men ... though it was but a small thing in the eye of man, yet a wonderful confusion it brought among all professors and priests. ${ }^{10}$ 
Although formal salutation is repeatedly referred to in the Quakers' writings as "such a trivial Thing," "a "thing of small importance"11_on both sides, Quakers and oppressors, one can clearly see that what occurs at these junctures really matters. The excessive rage to which nonobservance of norms of greeting and parting leads can be taken as evidence of the peculiar purchase of these mini-rituals, and also, perhaps, of the very violence that salutations are designed to hold at bay.

The Quakers' focus upon salutations was, in fact, in no way an aberration in early modern religious debate: the period's theological tracts and sermons are full of comment and controversy regarding these little rituals. Indeed, once one begins to contemplate the New Testament with an ear to these matters, the prominent place of salutations in the narrative of Jesus's life becomes striking: the most dramatic points of the Gospel stories are punctuated by marked greetings. It is with an Ave that Jesus's entry into the world is announced, closely followed in Luke by the narrative of the Visitation (the yet-unborn John the Baptist reacts to Mary's greeting, we are told twice; as Elizabeth says: "For lo, as soon as the voice of thy salutation sounded in mine ears, the babe leaped in my womb for joy" [Luke 1:44; cf. Luke 1:41]); it is with conspicuous greetings-Judas's kiss and "Ave, Rabbi" (or "Hail Master"), and the mob's "scornfull salutation,"12 "Hail, King of the Jews!"- that Jesus's betrayal is accomplished. It is with a kind of nongreeting, or rather the rejection of a gesture of greeting ("noli me tangere" [John 20:17]), that Jesus encounters Mary Magdalene, and with an emphatic triple greeting- "Pax vobis," "Peace be unto you" (John 20:19, 21, 26) - that he marks his return. Of this last postresurrection moment, Lancelot Andrewes declares:

Salutation is the very substance of the text: the rest but appendent, all. [...] The speech, of it selfe, is a Salutation: any will so conceive it, at the first hearing. And, if it were but so, and no more; that, were enough. CHRIST's salutations are not (as ours be) formall; but, good matter in them [...] no sooner risen, but pax vobis. Apertio labiorum, "the very opening of His lips" was with these words; the first words at the first meeting, on the very first day. It is a sign it is so in His heart. That which most grieveth us, we first complain of; and that which most affecteth us, ever soonest speak of. This is the first error. That which was first with Christ, is last with Christians, and I would it were so last. ${ }^{13}$

Jesus's life is thus narratologically framed by salutations. And the liturgical tradition adds to the gospels a focus upon Christ's final leave-taking both from his mother and from the apostles. Renaissance artists were tireless in their depictions of these moments of greeting and parting-the Annunciation, the Visitation, the leave-taking from Mary and the Apostles, the Noli me tangere, and the Pax Vobis. Worth noting, too, are Christ's 
injunctions to "salute no man by the way" (Luke 10:4) and "when ye come into an house, salute it" (Matthew 10:12), implicitly constructing a kind of hospitality canon. All these were much debated in sixteenth-century theological writings, as were Paul's oft-repeated instruction to greet those who are friendly to Christ's doctrines ("salute them with an holy kiss" [Romans 16:16; 2 Corinthians 13:12; 1 Thessalonians 5:26]) and not to greet those who "bring not this doctrine": "For he that biddeth him God speed is partaker of his evil deeds" (2 John 10-11). Salutations also play a central role in Paul's epistles ("The salutation of Paul with mine own hand, which is the token in every epistle" [2 Thessalonians 3:17]); indeed, these sometimes consist of little more than a bare greeting (most usually Gratia vobis et pax) - as Andrewes writes of the pax vobis, "Salutation is the very substance of the text." It is part of the legacy of all these marked and significant salutations that the pax, the dominus vobiscum, and the osculum pacis are such central components of Catholic liturgy.

The most prominent biblical salutation, however, is the Ave Maria; and this greeting is what I want to focus on for the remainder of this essay. As commentators have insisted since the early Middle Ages, it was the Ave itself that reversed the trajectory of sin set in motion by the biblical Eve. In liturgy, song and prayer, hymns, and antiphons, what remains remarkably consistent throughout the many variations is the "ave" (or, alternatively, "salve"): Ave Maris Stella, Ave Domina, Salve Regina; it is the opening salutation that rings through the centuries. ${ }^{14}$ As one prominent counterReformation writer, Anthony Stafford, puts it, "omnis terra revibrat Ave" ("All the world reverberates with Ave"). ${ }^{15}$ Throughout the middle ages and early modernity, theologians got significant mileage from Gabriel's Ave, finding in its three letters "the three persons [of the] holy Trinity-A, altitudo patris; V, veritas filly; and E, aeternitas spiritus sancti"-or spuriously tracing the etymology of the word: "Some Fryers have profoundly derived Ave of $(A)$ privatively taken, and ve, quasi sine va, that is without woe" (in fact ave derives from the imperative form of avere "to be or fare well"). ${ }^{16}$ The hopes raised by Gabriel's Ave are encapsulated by its reversal of the woe brought into the world by Eve, a play on words endlessly reiterated in these tracts:

QU: What three Letters are those that make us both Bondmen and Free? ANS: They are EVA, which inverted, are Ave, the Angels Salutation. ${ }^{17}$

Robert Southwell's “The Virgin's Salutation” follows a myriad of writers over the centuries who rework this Eva-Ave jingle:

Spell Eva backe and Ave shall you finde, The first began, the last reverst our harmes, An Angels Ave disinchants the charmes ... ${ }^{18}$ 
Here as so often, it is the salutation that seems to be the agent of "disinchant[ing]" the fallen world, undoing the evil spell under which the world has been laboring: the focus is upon the greeting rather than the content of the message Gabriel brings. ${ }^{19}$

The Annunciation was frequently depicted in the mystery cycles, as well as in other ritualistic forms of commemoration of this narrative, especially in the mass. In many of these there is a similar emphasis upon the Ave, the moment of salutation. For example, in one sixteenth-century arrangement of the Annunciation Mass (at Tournai), the high point is the singing of the words Ave, gratia plena, during which "Gabriel bows to Mary thrice"; ${ }^{20}$ in the Coventry Cycle (which Shakespeare was likely to have witnessed), ${ }^{21}$ the narrator figure (Contemplacion) instructs the audience: "lystenyth, sovereynes, here is a conclusyon: / how the Ave was mad[e] here is lernyd us," and ends the play with the words: "With Ave we begunne and Ave is oure conclusyon, /AVE REGINA C[A]ELORUM, to oure ladye we synge."22

Gabriel's Ave became the focus of heated controversy in the course of the Reformation. Protestant polemicists vehemently rejected the Catholic use of the angel's salutation as a prayer; for them, this "doltish custome" 23 was a scandalous misconstrual of the words of the bible, "mak[ing] a popish Orizon, of an Angelike salutation." ${ }^{24}$ Taking their cue from Calvin"very grosse is the folly of the Papistes, which as it were by a magicall coniuring, have turned this salutation into a prayer [... For] they salute one that is absent" 25 - the Reformers debated two closely related issues; that of intercession, and that of Mary's purported sinlessness (symbolized by her virginity):

[W] may see how grossely the Papists are besotted in martyring (that I may use Luther's word) the Angels salutation to Marie. For, 1. whereas a salutation is a civil thing, they have turned this into a devout praier. 2. not to Marie whome the words concerned alone, but unto God at whose hands the repeating of it meriteth pardon of many sinnes. 3. whereas salutation is to be done to a partie present among us, this saluteth one absent. 4 . whereas it was the angels dutie to carrie this message once to Marie; they thrust everie man and woman into the Angels office, to carrie the same message everie moment; as if it were a thing not alreadie accomplished. 5 . what further good can they wish to Marie now in heaven: But they have despised the wisedome of God; and what wisedom can be in them? ${ }^{26}$

Protestant theologians over and over argued that the Ave cannot be a prayer either for Mary or to Mary. In the first case, praying for Mary shows that she was not free from sin (as the Catholics claimed), for (as John Boys writes) "if in her life shee was full of grace, and free from all sinne as they teach impiously; then assuredly she did not need any prayer of man or Angell.” Praying to Mary turns her into an intercessor, contradicting the 
central Reformation tenet of sola fide, sola gratia and approaching idolatry. Protestant theologians asserted that saluting anything that cannot return the salutation, or anything that is not present-a statue, a saint, or dead person-implicitly renders the object an idol (hence the same goes for the All-hailing of the cross). The Reformers' critique of the saluting of what is absent gives implicit emphasis to the way in which salutation demands direct engagement; concomitantly, it brings out a key element in almost all early modern discussions of salutations, that of the importance of mutuality: that greetings must be "enterchangeable" or "reciprocall" 27 is something repeatedly stressed both in the courtesy manuals and in many theological tracts of the period. This question of mutuality is part of the reason that writers of this period insist that salutations are necessarily sublunary exchanges; as the seventeenth-century poet and lawyer Marc Lescarbot writes: "God saluteth no body: for it belongeth to him to give salvation, and not to wish it by praier." 28

It is worth noting that the Ave is sometimes referred to as "the angel's salutation" and sometimes as "the virgin's salutation." The vacillation may serve to remind us of two things: First, the question of who is in a position to salute here-from what place, and in what capacity, can one offer hospitality to the other? What gives one the right to welcome? These are questions that Derrida has posed acutely, and we will return to them later. Second, referring to Gabriel's Ave as "the virgin's salutation" should serve to remind us that in the gospel narrative (and later representations) Mary is not recorded as returning the greeting; she is so "troubled at [Gabriel's] saying" that all she can do is "cast in her mind what manner of salutation this should be" (Luke 1:29). Her silence may be taken to underline the uncalled-for nature of Gabriel's arrival, and hence its potentially traumatizing effect. It is (in Derrida's terms) "the unforeseeable and irresistible irruption of a visitation" rather than the result of "the hospitality of invitation." 29 As the myriad medieval and Renaissance depictions emphasize, the moment is, first of all, a crossing of a boundary; it is a radically disruptive moment: Mary is often depicted in artistic representations as appearing to be shocked by the arrival of the angel, almost invariably she is interrupted (while reading-usually a book of prayer-or sometimes while weaving). ${ }^{30}$ Mary's stunned (Erasmus describes her as "dismayed") 31 nonresponse is emphasized in many of the late medieval dramatizations of the Annunciation. In the N-Town cycle, for example, Gabriel "makyth a lytyl restynge and mary be-holdyth hym." ${ }^{2}$ The dramatist here, writes Gail Gibson, "risks stillness and silence to enforce his point": the Angel's Ave is followed by a "charged and expectant silence." 33

From a theological point of view, the Annunciation is so important a moment in Christian thought because, of course, it marks the entry into history of the salvation of humanity. In nearly all its representations, this interruptive crossing of a threshold receives great attention. There is a close connection between Mary's (Catholic) role as intercessor and the message that crosses the divide-intercedes—between the angel and the virgin. 
As Subha Mukherji has written, "the mythical moment [of the Annunciation] is realised at a threshold ... between invitation and invasion, hospitality and occupation." ${ }^{34}$ It is at the threshold of the arrival of the Christian world. The column (or other architectural feature) that symbolically divides the Angel Gabriel from Mary in so many Annunciation scenes, as Georges Didi-Huberman argues, "marks both the uncrossable distance and mysterious journey through which the Incarnation has crossed every conceivable threshold" (the wordplay here- "conceivable"-emphasizes the almost literally inseminating capacity of the Ave). ${ }^{35}$ But could not something similar be said of every meeting? As I began by suggesting, there is always some unbridgeable distance to be crossed, an element of radical uncertainty, even mystery, to the journey made when the paths of two human beings intersect. The Annunciation is thus a paradigmatic meeting - this is one of the sources of its power. Christopher Pye, calling the Annunciation "the ur-instance of subjective interpellation in western culture," ${ }^{36}$ draws attention to the threshold between viewer and scene featured in so many Annunciation depictions: "the combination of perspective recessions and flattened planes seems at once to draw us in and bring us up short." ${ }^{37}$ And while it is usual to read these threshold-crossings theologically, as representations of the mysteries of the incarnation, one might also be reminded here of the way in which all greetings (and partings) at once "draw us in and bring us up short." One could say that Mary's nonresponse brings out the element of incommensurability in all greetings. ${ }^{38}$

Early modern writers played with the etymological relation between salvation and salutation (indeed the latter is just one letter away from saluation in its most common Renaissance printhouse form): ${ }^{39}$ both words derive from the Latin salus, meaning "health" (as both hail and holy derive from the Old English halig, "health or wholeness," something of which Heidegger makes hay). Indeed, Renaissance theological treatises and tracts often link the rituals of proper and heartfelt greeting to one's own salvation (as does Shakespeare's Corin, by implication, when he speaks of "find[ing] the way to heaven / By doing deeds of hospitality" [As You Like It, 2.5.83-85]). As William Phiston's The schoole of good manners (1595) puts it, "a reverent show in countenance or maner of greeting ... is a signe of God's great lasting favour, and of everlasting life in heaven." 40 In trying to understand the enormous emphasis placed in this period upon greetings, and especially upon Gabriel's salutation, it may be helpful to turn to Derrida's various writings on the word salut. Like those many early modern theologians, Derrida plays on the common root of salutation and salvation, but he does this in order to make an argument for the ethical necessity of greeting as offering something like the opposite of salvation. He writes of

the double sense of the word "salut," the greeting which one addresses to the other and the salvation which saves: the salut, on the one hand as a call launched ... and on the other hand, the salut of salvation. 
The two saluts greet each other from nearby or from afar, one like the other, one operating and co-operating in the other which remains nevertheless apart, a sort of homonym or metonymical doublet. ${ }^{41}$

But for Derrida there is an irreducible difference between these two saluts: salut-as-salvation manifests an impossible (if all too human) desire to be immune-from death, disease, the thousand natural shocks that flesh is heir to; salut-as-greeting is an unconditional opening to the other, a receiving (accueillir) without presupposition or guarantee, "a benediction without any hope of salvation, an ex-hoped-for [exespéré] salve, an incalculable, unrepresentable salutation in advance renouncing Salvation." 42 As Derrida reiterates elsewhere: "the salut to the other ([Heidegger's] Gruss, greeting) must suspend all assurance or all promise of salut as that which saves." ${ }^{33}$ True greeting "open[s] oneself to an other who can always cause harm or do evil"; 44 and it is also an open-ended salut to "the other recognized as mortal, finite, in a state of neglect [à l'abandon]." 45 In relations between human beings, unlike in relations between divinities and humans, there can be no guarantee of health or safety; all one can hope for is reciprocation. This suspension of (salvific) assurance, and the attendant anxiety, lies at the heart of all human salutation - as does the yearning to transcend these uncertainties. Derrida repeatedly calls for this kind of earthbound, nonteleological salut derived from, and dependent upon, the essential openness of our relations with others, a salutation "That has no relish of salvation in it" (Hamlet, 3.3.92). It is the essence of the unforeseeability or "opening," as Derrida describes it, that hospitality enacts. ${ }^{46}$

There are at least two moments in Shakespeare where we might hear an echo of the Ave Maria. ${ }^{47}$ First, there is Lucio's salacious greeting upon accosting Isabella the novice in her nunnery: "Hail virgin, if you be ..." (Measure for Measure, 1.4.16). Perhaps Lucio is (as is his wont) casting aspersions, or perhaps he is implying that a virgin, in this Vienna, is akin to a miracle; certainly, conception in this play could hardly be further from immaculate. (It is interesting to note in this context that the penultimate claim in the central accusatory document against Christopher Marlowe (usually referred to as the Baines libel) is that the playwright is said to have declared " $[t]$ hat the Angell Gabriell was Baud to the holy ghost, because he brought the salutation to Mary"; Marlowe's alleged joke, like Lucio's, plays on the scandalous potential of salutations to be sexualized). In any event, Lucio arrives at the nunnery aiming to elicit Isabella's intercession with Angelo in order to save her brother, so that the referencing of the annunciation is hardly irrelevant. (The name Lucio in this context may evoke Lucifer, the fallen angel, as well as perhaps Luke, the gospel source of the Ave Maria; he himself is acting here as intercessor vis-à-vis an Angel[o].) It is also worth recalling that the dissolution of the monasteries and nunneries in England was closely linked to the disengagement from Mariolatry; hence the evocation of the annunciatory moment has a peculiar poignancy in this context. 


\section{2}

Perhaps "Hail virgin, if you be" means not only "I hail you as a virgin (but am skeptical of your virginity)" but also "I hail you if you are a virgin-if not, there's no point in my hailing you, since you can't serve as an intercessor if you're not immaculate." (Si peccatrix, non deprecatrix, as the Reformers' tag went: if a sinner, not an intercessor (deprecatrix: "one pleading for mercy"); more on this hereafter. ${ }^{48}$

And then there is Cassio's greeting to Desdemona in Cyprus:

\section{O, behold!}

The riches of the ship is come on shore!

You men of Cyprus, let her have your knees.

Hail to thee, lady! and the grace of heaven,

Before, behind thee, and on every hand,

Enwheel thee round!

(Othello, 2.1.82-86)

Thomas Rymer's scathing critique of this speech- "In the name of phrenzy, what means this Souldier? or would he talk thus, if he meant any thing at all?" 49 — can alert us to the oddness of Cassio's greeting. We might here recall that it is this particular scene, even more than the notorious handkerchief, that caused Rymer to fulminate and accuse Shakespeare of "un-hallowing the theatre, profaning the name of tragedy" in Othello. ${ }^{50}$ Alongside the "phrenzy" of Cassio's praise, it is Desdemona's subsequent off-color banter with Iago that incensed Rymer (and has perplexed many critics and audiences since). Indeed, the barely buried Marian undercurrent of Cassio's salutation seems utterly out of place here: Cassio is no angel, Desdemona no Virgin Mary (though, pertinently, she may—or may not—still be a virgin); the Ave here is uttered not by the one arriving but by the one who is already there (though he has himself just arrived). I am far from the first, however, to see in these words an echo of the Ave Maria. Peter Milward labels it a "remarkable" echo of the Annunciation; E. A. J. Honigmann suggests that Cassio's welcome "comes close to being a 'Hail Mary"; Chris Hassell sees "Cassio's extraordinary salutation and praise of Desdemona" as a "Marian allusion." ${ }^{51}$ It is worth recalling here, too, that both Gioachino Rossini and Giuseppe Verdi saw fit to add an Ave Maria to their respective Othellos. ${ }^{52}$ (In both, the Ave functions, interestingly, not as a greeting but as a parting.) Indeed, in Verdi's opera, Desdemona's aria follows hard upon her passionate parting from Emilia; in its stillness and pathos, it is one of the most moving moments in his masterpiece.

Verdi-along with his librettist, Piero Boito-chose to open his great opera at this juncture (act 2, scene 1). The scene of staggered arrivals in Cyprus gives us a kind of smorgasbord of greetings-the businesslike, the rushed, the naval, the courtly, the heartfelt, and the hyperbolical. What we have been led to expect at the close of act 1 is a meeting in the military sense, a martial encounter; instead, we get a series of joyful, quasi-amatory 
reunions. The greetings appear to mark a watershed, a transition from the influence of Mars to that of Venus. Each of the arriving ships gives the traditional naval salute, letting off a cannon: "They do discharge their shot of courtesy" (2.1.57); "They give their greeting to the citadel" (1.94). Here again, the veil that covers the potential violence in every encounter is thin.

The multiple greetings in this scene evoke in particularly sharp form the problem of who is in a position to welcome as well as some of the other enigmas of welcoming-their liberality (in every sense) and inherent power plays. Derrida writes of "the danger of ... usurpation" in every welcoming speech act:

To dare to say welcome is perhaps to insinuate that one is at home here, that one knows what it means to be at home, and that at home one receives, invites, or offers hospitality, thus appropriating for oneself a place to welcome [accueillir] the other, or, worse, welcoming the other in order to appropriate for oneself a place and then speak the language of hospitality. ${ }^{53}$

Here, the Cypriots themselves are hardly in a position to be full hosts, since the island is a military garrison occupied by the Venetian state (though this also means that they are, oxymoronically, essentially obligated to provide hospitality). ${ }^{54}$ The order of the Venetian fleet's arrival (first Cassio, then Desdemona, accompanied by Iago and Emilia, and finally Othello), as well as the fact that they are all guests in a foreign land, adds to this sense that no one here is in a position properly to occupy the role of host. This is, as Derrida argues, inherent to the notion of the host: Cassio is, precisely, both host and guest or stranger, an embodiment of the original etymology of the Latin hospes as described in Emile Benveniste's classic study of IndoEuropean language and society. ${ }^{55}$ The questions (From what place can one offer hospitality? What gives one the right to welcome?) are never far from the surface of the opening scene of Othello's second act.

Why does Shakespeare conjure with the Ave Maria at this juncture? Certainly, there is hyperbole, idealization-even idolization-in Cassio's elaborate flourish of greeting. As Neill writes, “it is not simply Cassio's habit of courtly hyperbole that licenses the lieutenant to dress [Desdemona] in the poetry of Marian adoration." 56 The rhetoric is part of the religious discourse that permeates the entire play and that often raises Desdemona to a quasi-divine position. But more specifically, and keeping in mind the framework of the central Reformation controversies about the Ave Maria, we can say that Cassio's salutation does two things: it puts (or rather keeps) in our minds the unresolved question of Desdemona's virginity, and it places "the divine Desdemona" in the position of potential intercessor. The issue of Desdemona's virginity, and hence of the meaning of virginity as such in the world of Othello, is a matter Shakespeare is careful to maintain hovering at the edges of our consciousness throughout the play. Janet Adelman's 
description of Othello's handkerchief as "a talisman that guarantees both virginity and its loss" moves toward a potential identification of Desdemona with the Virgin Mary: "the handkerchief increasingly becomes a fetishistic representation of specifically maternal virginity as the impossible condition of male desire." ${ }^{57}$ Analyzing "Othello's need for Desdemona to remain intact," Adelman adds that her (imminent or accomplished) loss of virginity means that she "can no longer be the vessel of his perfection," the signifier of his intactness or wholeness. ${ }^{58}$ "Had she been true," says Othelloafter he has killed his wife-he would not have sold her for "such another world / Of one entire and perfect chrysolite" (5.2.143-144). His imagery in act 5-the chrysolite, the discarded pearl (5.2.342-344), the "monumental alabaster" (5.2.5)—repeatedly depicts Desdemona in such terms of entirety and unbroken perfection, a kind of statue that is, ipso facto, virgo intacta. She represents for Othello (and not only for Othello) something "intact, uncontaminated," in Stanley Cavell's descriptive phrase. ${ }^{59}$ (In his essay on the play, Cavell interrogates "Othello's placing of a finite woman in the place made and left by Descartes for God." ${ }^{60}$ )

It is the idea of Desdemona as somehow "entire and perfect" that gives Iago his opening - he sees that the idealization can hardly help but collapse in the face of flesh-and-blood reality. Cassio's Ave Desdemona opens the door to Iago's concomitant debasement just a few lines later: you women, he says, are "saints in your injuries, devils being offended" (2.1.109), which we could gloss as introducing Cassio to the notion that (all) women have injuries-they aren't intact (and, being offended, they offend-they aren't sinless). (Compare the Protestant theologian Boys: "The whole neede not a Physitio[n], saith Christ: but Marie calles for a salue, therefore surely she had some sore." ${ }^{61}$ ) We might similarly view Desdemona's subsequent banter with Iago as implicitly aimed at negating the (desexualizing) idealization of Cassio's greeting. We can see Iago's modus operandi in what he is able to do with the simple gestures of greeting in 2.1. Note that he, like the Quakers and their oppressors, precisely indicates both the triviality of the gestures of courtly greeting and their potentially momentous implications: "with as little a web as this I will ensnare as great a fly as Cassio" (1.166). His bracing commentary takes advantage of the way the courtesies of greeting can look like courtship, and courtship can be made to appear close to a sexual advance. It is noticeable how easily Iago slides from "courtesy" (1.99) to "courtship"- "I will gyve thee in thine own courtship" (1.167)—and back to "courtesy" (1.172). Greetings involve the preliminary establishment of a relationship between surfaces or exteriors, a delicate negotiation of distance and proximity; Iago, in his evocation of "clyster-pipes" (1.174), almost physically transforms the gestures of salutation into the rawly penetrative. Not that Iago undoes the alienation implicit in Cassio's greeting of Desdemona; he merely reverses it—turns it inside out. As Adorno writes: "Estrangement shows itself precisely in the elimination of distance between people. For only as long as they abstain from importuning one another ... is there space 
enough between them for the delicate connecting filigree of external forms in which alone the internal can crystallize." 22 Iago's "little ... web" (1.168), of course, aims to ensnare, or to hyperconnect, which amounts to the same thing: alienation rather than connection. If Cassio's repeated gesture of kissing his three fingers is a displacement from kissing the other (the lady herself), Iago reverses the (upward) displacement, focusing attention back (down) onto what kissing itself attempts to displace, namely, the crudest or most carnal aspect of relations: "Yet again, your fingers to your lips? Would they were clyster-pipes for your sake" (11.173-174). ${ }^{63}$ Greetings, for Iago's purposes, are no more than "an index and obscure prologue to the history of lust and foul thoughts" (11.249-50). If Cassio's Ave creates an infinite space between himself and Desdemona, Iago collapses that delicate establishment of tactful space ("that fine mesh") essential to all greetings (and partings). It is precisely in and through the gestures of courtly greeting in this scene that Iago finds sexuality: "They met so near with their lips that their breaths embraced together. Villainous thoughts" (11.250-2). Like all of Iago's insinuations, Othello eventually takes on this idea, for example, in the image of "[t]he bawdy wind, that kisses all it meets" (4.2.78); compare Leontes's maddened collapsing of "leaning cheek to cheek ... meeting noses ... Kissing with inside lip" (and so forth) with "note[s] infallible / Of breaking honesty." 64

It is as if the play is working something out, through Iago's debasement of Cassio's Marian homage to Desdemona, about the very concept of a Blessed Virgin, understanding its meaning on the basis of a diagnosis of the inverse of the fantasy. Cassio's Ave Maria places Desdemona on a pedestal, relinking the matter of virginity to a soteriological framework: his "Hail to thee, lady! and the grace of heaven," in invoking the best-known form of the Ave Maria (gratia plenis), puts this issue in the context of the Virgin's purported status as impeccabilis. Peter Brown, tracing the emergence and power of the idea of the perpetual virginity of Mary in medieval Christianity, shows how Mary's virginity "stood for all that was unbroken and sacred in the world"-all that could remain unscathed (in particular by sexuality). ${ }^{65}$ Eamon Duffy describes the "elaborate appeal [in late medieval English Christianity] to Mary and John the Evangelist precisely in their character as inviolate virgins": "the dynamic of such prayers was not designed primarily to present the chastity of the saint as a model, but as providing the basis of their intercessory power." ${ }^{\prime 6}$ The Virgin's unscathedness is the source of her sacred power. Herein lies the link between virginity, intercession, and salvation. It is by virtue of being herself unscathed that Mary is able to offer the hope of such wholeness to humanity, and thus to be positioned as intercessor. We might here recall that for Derrida, what lies at the heart of the need for salvation is the desire to become "the intact, the unscathed, the safe (heilig)." 67

Cassio's Ave in Cyprus suggests that she symbolizes for him something along these lines, positioning her as a Mary-figure and implicitly endowing 
her with the power of salvation. (Certainly, Shakespeare goes out of his way to represent Cassio elsewhere as thinking in salvific terms: "Well, God's above all, and there be souls must be saved, and there be souls must not be saved ... I hope to be saved ... the lieutenant is to be saved before the ensign" [2.3.94-102].) The hyperbolic greeting comes immediately after Cassio has linked Desdemona with both safety and guiltlessness. He has just described the storm in the following way:

Tempests themselves, high seas, and howling winds,

The guttered rocks and congregated sands,

Traitors enscarped to clog the guiltless keel,

As having sense of beauty do omit

Their mortal natures, letting go safely by

The divine Desdemona.

The guiltlessness is transposed from Desdemona to the ship carrying her ("Guiltiness I know not," she says on her deathbed [5.2.38]). If "omit / Their mortal natures" means that the murderous seas, winds, and rocks cease to be death-dealing, it also carries the implication that the nature of being mortal can somehow be omitted-the quintessence of salvific thinking. (The speech might also be taken as offering some insight into the relation between aesthetics- "As having sense of beauty" — and such thinking.) "The divine Desdemona" escapes "safely" - intact, unscathed. Sticking with Desdemona here might seem to offer safe passage; at this point neither we nor Cassio know whether Othello has escaped the mortal nature of the tempest (or indeed whether Desdemona is still a virgin). Here it is Desdemona who is implicitly positioned as the savior with whom one might throw in one's lot-not Othello, the martial hero.

Northrop Frye, in his work on Romance, brings a different perspective to bear on the idea of virginity, but with similar conclusions: "What is symbolized as a virgin [in Romance] is actually a human conviction ... that there is something at the core of one's infinitely fragile being which is not only immortal but has discovered the secret of invulnerability that eludes the tragic hero" 68 (and especially, we might speculate in the context of Othello, the potentially circumcised tragic hero). ${ }^{69}$ Thus, it may be that the final nail in Desdemona's coffin lies in her response to Othello's "What, not a whore? ... No, as I shall be saved" (4.2.86). It is an exchange that precisely pinpoints the delicate relation between salvific thinking and sexual purity or intactness. For from the point of view of Mariolatrous thinking, or from that of Frye's Romantic hero, this is, so to speak, the wrong-the worst possible-answer: it is not so much that it shows that she is not looking to Othello (but rather to Christ) to save her; it is, more crucially, that at some level Othello has needed her to offer safety-to save him, not to be saved. Recall: "My life upon her faith" (1.3.295). "To make his 'life' depend upon 
'her faith' is already to hold her responsible for anything that may happen," writes Harry Berger. ${ }^{70}$ Here again, we might imagine Othello thinking, "if she needs saving, she can hardly be impeccabilis, free of sin-is no virgin-must be a whore." This is close to the logic of Protestant theologians vis-à-vis Mary:

He that hath no sinne, wants not a Saviour: ... Our Advocate is our propitiation for sinne: but the propitiation for sinne, knew no sinne. Ergo, quae egebat, non agebat advocatum. And therefore Mary, who needed a Saviour her selfe, could not be a saviour of other. ${ }^{71}$

The emotional investment in Desdemona, by both Othello and Cassio, is too great-it can only function on the basis that she is beyond sin, beyond sexuality, beyond the human.

In making Desdemona a demi-goddess, Cassio denies her (sinful or errorprone or just unideal) humanity, just as devotees of the Virgin Mary thought her "not to be considered as a meere woman, but as a Type, or an Idea of an Accomplished piety." "72 But as Kenneth Burke reminds us, Cassio's "reverence for Desdemona is matched by his cynical attitude to Bianca"73 either way, the real, imperfect person in front of him is avoided. (From this perspective, the old misogyny of virgin or whore is rooted in, is one version of, a refusal or inability to see the female other as a person.) And if treating the other as a type is one way of avoiding the other, using intercessors is another. If one function of Cassio's greeting is to create distance by raising Desdemona to a quasi-divine status, its second crucial function is to place Desdemona in the position of potential intercessor; it thus implicates the problem of indirectness in relations with others. Already here, before Iago has begun to exert his influence, and also before Cassio has reason to think he has need of intercession-he implicitly positions Desdemona as mediatrix. If you are, in Cassio's odd phrasing, "enwheel[ed] round" ("Before, behind thee, and on every hand") by "the grace of heaven," you might not be deemed very approachable. Nor does "let her have your knees" sit very well beside Levinas's "uprightness of the welcome made to the face." 74 Coleridge called this strange greeting "Cassio's ... perfectly disengaged praise of Desdemona," 75 for it is at precisely the moment of potential engagement- the moment of greeting - that he wheels away from the fleshand-blood person entering the scene.

It is also particularly noticeable, in this scene of multiple greetings, that Cassio and Othello are the only significant characters who do not greet each other-at all. In a scene of so many greetings, why should this be so? This is surely not a matter of mere dramatic expediency, for it is linked to a second, far more consequential question: Why, after the nighttime debacle in Cyprus, does Cassio not go directly to Othello with an apology and a plea for reinstatement? It is, I suggest, this habit of nonengagement or indirectness, rather than his "bestial" weakness for alcohol or his courtly pretensions, 
which is the central cause of his downfall (compare Polonius's fondness for "indirection," or Duke Vincentio's dubious, devious methods, or Pandarus's unpalatable role as go-between). ${ }^{76}$ It is of course Iago who convinces him to address Othello via Desdemona, but his "Hail to thee, Lady" can hardly be attributed to Iago's scheming. Cassio's rhetorical flourish of greeting is almost the first we see of him in the play; by 3.1 we can see that the use of mediators, especially upon greeting, is integral to his way of being in the world: "Masters, play here, I will content your pains; / Something that's brief, and bid 'Good morrow, general'” (3.1.1-2) he instructs the musicians outside Othello's window, deploying them to sweeten the ear of his general (with-under the circumstances-a strikingly underpowered greeting). That this moment bears such close comparison with Cloten's modus operandi (in Cymbeline, 2.3) is telling. A few lines later Cassio announces that "I have made bold, Iago, to send in / To your wife: my suit to her is that she will / To virtuous Desdemona procure me / Some access" (2.1.33-35). Bold he is not ("I have made bold" is surely a sly joke upon the speaker): Cassio deploys an intercessor even in approaching his chief intercessor. Indeed the Clown in this scene seems to divine this about Cassio and to make fun of the habit:

CASSION: Dost thou hear, mine honest friend?

CLOWN: No, I hear not your honest friend, I hear you.

By the time we see him "steal away so guilty-like" (3.3.38) at the imminent arrival of Othello, we may be expecting to see him avoiding direct engagement. Admittedly, this is Iago's tendentious description, but it is Cassio who rejects Desdemona's injunction that he stay: "Madam, I'll take my leave ... I am very ill at ease, and / Unfit for mine own purposes" (3.3.29-31). It is just this sense of being "[u]nfit for [his] own purposes"-of having to rely on another for one's salvation-that Iago manipulates to such devastating effect.

Indirection and intercession replace engagement at almost every turn in Othello, serving as a strategy of avoidance, a technique of evasion. Cassio, Brabantio, Roderigo, the Duke of Venice, and of course Othello himself all place their faith in intermediaries, instead of approaching the other directly. The pattern or precedent for this use of mediators is set by Iago early on, indeed before the beginning of the play. In his opening exchange with Roderigo we learn-the information seems gratuitous-that Iago himself has apparently deployed intercessors to approach Othello on his behalf: "Three great ones of the city, / In personal suit to make me his lieutenant, / Off-capped to him" (1.1.7-9); but Othello "[n]onsuits my mediators" (1.1.16). Perhaps this failure has something to do with Iago becoming the play's arch-intercessor, a sort of demonic version of a mediatrix. But Iago is not the only one who has been availing himself of mediators. As we discover halfway through the play, this precedent too has a precedent, for 
Othello himself has deployed an intermediary throughout his wooing of Desdemona: "from first to last," we learn, Cassio "went between us very oft" (3.3.97-102). What is this but a sign of his sense of his own insufficiency or unfitness for his own purposes? ${ }^{77}$

Critics have sometimes noticed the profoundly monadic nature of the characters in Othello. G. Wilson Knight described the play as a "mosaic" of isolated subjects and objects, in which the characters all possess an "inward aloofness." Kenneth Burke's reading finds in the play a representation of the estrangement inherent to the notion of property as such. A. P. Rossiter claims that the multiple triangulations in Othello add up to "an infernal trigonometry" where "the closeness of all the personae which looks like intimacy reveals, on examination, an intricate pattern of insulations." Harry Berger, Jr., points to "the spectre of contaminated intimacy" that the play offers. ${ }^{78}$ To these one should add that the ease with which Iago is able to keep the other characters apart has an essential role in the play; what he draws on and controls so expertly is their willingness-their all-toowillingness-to be segregated from one another. It is largely because they willfully avoid facing each other, because they eschew direct engagement and resort to intermediaries, because they resort to "the third interrupting the face to face of the welcome of the other" ${ }^{\text {79 }}$-that face-to-faceness so crucial to hospitality-that Iago's machinations are so effective.

These are the play's original sins. Recall from act 1: "And bade me, if I had a friend that lov'd her, / I should but teach him how to tell my story, I And that would woo her." In the comic mode, Desdemona can joke and flirt with Othello about intercession; she knows that the indirection will find direction out. But intercession has its costs and consequences. By the time Othello parts from his wife with "[f]arewell, my Desdemona, I'll come to thee straight" (3.3.88), we might hear an ironic inflection in that "straight": we know that coming to someone "straight" (in the secondary sense of "directly") is not the way of these characters. From the beginning to the end of the play- "from first to last"-indirectness prevails: "Will you, I pray, demand that demi-Devil / Why he hath thus ensnared my soul and body?" (5.2.298-299); even at the death, Othello is still not facing the other directly. These may be child's games ("You ask him ..."), but they have fatal costs.

I do not think, however, that Rossiter's (or Burke's, or Knight's, or Berger's) readings constitute accurate characterizations of the whole play. The contrast between Cassio's "Hail to thee, lady" and Othello and Desdemona's mutual greeting a few lines later is, to my ear, striking (though of course that too has its undertones of trouble to come). Desdemona's "[l]et's meet him and receive him" (1.2.176) gives a sense of her greeting as the kind of unconditional opening to the other-the accueillir-of which Derrida writes in his meditations on hospitality. Similarly, we could say that the Quarto's stage direction- "they kisse" (omitted from the Folio)-may hint at the mutuality of the greeting, since "the usual formula is " $[\mathrm{He}]$ kisses her"'; "they kisse," writes Honigmann in his edition, "may mean that she 
gives as good as she gets." 80 (Compare Cressida: "In kissing, do you render or receive?" [Troilus and Cressida, 4.5.40].) It is precisely the fall from the possibility of such greeting, such directness of mutual engagement, face to face, that the play documents, and that makes it so hard to stomach. Othello and Desdemona are not onstage alone again until it is too late-until he has already stoned his heart to her. By the end of the play, Othello can only imagine his posthumous meeting with Desdemona in these anguished terms: "When we shall meet at compt / This look of thine will hurl my soul from heaven" (5.2.271-272). In his mind, Desdemona's final greeting will be an everlasting leave-taking-instead of offering salvation, the last greeting will set the seal upon his damnation. The difference between the greeting at Cyprus and this final vision is an index of the fall the play documents. For Othello is a tragedy about (among other things) the dangers of intercession, of not appealing directly to the other, of not greeting the other face to face, unconditionally, à l'abandon, as Desdemona greets her husband upon his arrival in Cyprus—for the last time: "My dear Othello!" (2.1.177).

\section{Notes}

I thank David Goldstein, Julia Lupton Reinhard, John Kerrigan, Adelais Mills, and Joe Moshenska for their generous and helpful comments on drafts of this essay.

1. Jacques Derrida, Monolingualism of the Other: The Prosthesis of Origin, trans. Patrick Mensah (Stanford, CA: Stanford University Press, 1998), 68.

2. Emmanuel Levinas, Otherwise than Being or Beyond Essence, trans. Alphonso Lingis (The Hague: Martinus Nijhoff, 1981), 150. This "third" is not to be confused with Levinas's "tertialité" whose illeity bears witness to the justice of the face to face.

3. All quotations from Othello are from the Oxford edition, ed. Michael Neill (Oxford: Oxford University Press, 2006).

4. Levinas, Totality and Infinity, trans. Alphonso Lingis (Pittsburgh: Duquesne University Press, 1969), 82.

5. Oxford English Dictionary (OED), s.v. "greet, v. 1." For Derrida on the ambivalent etymology of hospitality, see, e.g., his "Hostipitality," trans. Barry Stocker with Forbes Morlock, Angelaki 5, no. 3 (December 2000), 3-18, 3 and 15n4.

6. OED, "greet, v. 1."

7. Theodor Adorno, Minima Moralia: Reflections on a Damaged Life, trans. E. F. N. Jephcott (London: Verso, 2005), 36-37.

8. Quotations from Shakespeare (other than from Othello) are from The Oxford Shakespeare, 2nd ed., ed. Stanley Wells and Gary Taylor (Oxford: Clarendon Press, 2005).

9. Benjamin Furly, The worlds honour detected (London, 1663), 50.

10. The Journal of George Fox, ed. John L. Nickalls (Cambridge: Cambridge University Press, 1952), 37.

11. The History of the Life of Thomas Ellwood, ed. S. Graveson (London: Headley Brothers, 1906 [1714]), 59: "wondering that so Wise a Man as he was should take Notice of such a trivial Thing as the Putting off or keeping on a Hat ..."; William Caton, The moderate enquirer resolved (London, 1658), 43. Cf. Vives (echoing Erasmus): "Howe small thynges, and of how light cost are salutation, 
faire spech, gentelnes, reuerence? And yet howe gret frendshyp engender they, if they be vsed? what amities do they dissolue, if ye omyt them?": Juan Luis Vives, An introduction to wysedome (London, 1544), fol. Gii.

12. Johann Ferus, The doctrine \& dominion of the crosse (London, 1659), 288.

13. Lancelot Andrewes, XCVI. sermons (London: Printed by George Miller for Richard Badger, 1629 [1609]), 415 (A Sermon Preached before the King's Majestie, at White-Hall, On the XVI. of Aprill, A. D. MDCIX. being Easter Day). There is of course a great deal to ponder in Andrewes's sermon on Christ's salutation; suffice here to note that he suggests that Christ's salutations are inseparable from the essence of what he stands for; "at the first hearing," with "the very opening of His lips," we encounter what "is so in His heart."

14. Note, for example, the emphasis on words of greeting in the "Ave Regina Caelorum" (one of the four Marian antiphons): "Ave, Regina Caelorum, I Ave, Domina Angelorum: / Salve, radix, salve, porta ..." ("Hail, O Queen of Heaven, / Hail, O Lady of Angels: / Hail! thou root, hail! thou gate ...").

15. Anthony Stafford, The Femall Glory: or, The life, and death of our Blessed Lady, the holy Virgin Mary (London: Printed by Thomas Harper, for John Waterson, 1635), fol. C4. As Jaroslav Pelikan points out, the dispute over the best translation and interpretation of kecharitömene (full of grace) "should not obscure the far more massive role played by the opening salutation, Ave/Hail, through the centuries. It came to open the prayer that has, it seems safe to estimate, ranked second only to the Lord's Prayer" (Mary Through the Ages: Her Place in the History of Culture [New Haven: Yale University Press, 1998], 14).

16. John Boys, An exposition of the festiuall epistles and gospels vsed in our English liturgie (London: Printed by Edward Griffin for William Aspley, 1615), 343. Cf.: "here [th]is name Eva is turned Ave / [th] at is to say with-owte sorwe are [th]e now" (Ludus Coventriae; or, The Plaie Called Corpus Christi, ed. K. S. Block, Early English Text Society, e.s.120 [London: Oxford University Press, 1960], 104 (11. 219-20); Gibson notes the familiarity of "the medieval pun spoken by the angel Gabriel as he hails God's bride" (Gail McMurray Gibson, The Theatre of Devotion: East Anglian Drama and Society in the Late Middle Ages [Chicago: University of Chicago Press, 1989], 161). Erasmus has some fun with the (correct) derivation of "ave" in his Colloquies: "Ave praeceptor. $\operatorname{Re}(\mathrm{a})$ Equidem malim habere quam avere (Ave, master. Answer. In truth, I'd rather be [well] than have [much]") (The colloquies or familiar discourses of Desiderius Erasmus of Roterdam [London: Printed by E.T. and R.H. for H. Brome, B. Tooke, and T. Sawbridge, 1671], 2).

17. William Cecil, Baron Burghley, Precepts, or, Directions for the well ordering and carriage of a mans life (London: 1636), 60.

18. Robert Southwell, The virgins salutation. [from Moeonice] (London, 1595), fol. B3v; "disinchants the charmes" presumably implicates the undoing of our bewitchment by our first mother's sexual fall. Cf. also John Boys's “let us examine now their [i.e., Catholic scholastics'] injuring of every word in particular, the first is [chaire], which they translate Ave, turning upside downe the letters of $E v a$, the woman who did occasion the worldes woe, was named Eva, therefore it was fit that Mary who bare Christ, the worlds joy, should be saluted with Ave; being opposite in name so well as in nature; this playing upon the word is pretie, but not pithie, because Ave is latine, whereas Eva is Hebrew, and greeke, so that the Fryars wit hath out runne the holy spirits wisedome in this exposition and transposition of Eva and Ave" (Boys, An exposition, 342-3). 
19. While the "first word," "Ave" (or "[All] Hail”), is frequently glorified in the theological writings of the period, it is also often vilified as the word under which Judas veiled his treachery. See, for example, Samuel Rowlands' The betraying of Christ Iudas in despair (London, 1598):

All hail, the Angel reverently did use, With heav'nly tongue, to holy virgin's ear, All hail, in Pilat's hall they did abuse, That scorning Christ, presented Aue there, Highest in favour of all women gain'd it, And chiefest sinner of all men, profan'd it. First word it was, God's gracious love t'unfold Beginning at our saviour's incarnation, First word wherewith false Iudas bought and sold, Whose traffick turn'd Christ's death, his own damnation [B3 verso]

On this topic, see especially Denys Turner, Faith, Reason and the Existence of God (Cambridge: Cambridge University Press, 2004), chapter 5.

20. See Karl Young, The Drama of the Medieval Church, vol. 2 (Oxford: Clarendon Press, 1933), 246.

21. As Chris Hassell points out, "Shakespeare is most likely to have seen the Coventry mystery cycle as a child, since it occurred only a day's walk from Stratford and was not suppressed by Reformation authorities until 1579" (R. Chris Hassell, Jr., "Intercession, Detraction, and Just Judgment in Othello," Comparative Drama 35, no. 1 [Spring 2001], 43-68, 66n22).

22. In Samuel B. Hemingway, ed., English Nativity Plays (Henry Holt \& Company: New York, 1909), 99-100 (Coventry Visitation (III), 164-5 \& 198-9).

23. John Keltridge, Two godlie and learned sermons (London: Imprinted by Richard Jhones, 1581), 146.

24. William Fulke, A defense of the sincere and true translations of the holie Scriptures into the English tong (London: Imprinted by Henrie Bynneman, 1583), 463.

25. Calvin, A harmonie upon the three Evangelists, trans. E. P. (London: George Bishop, 1584), 22; cf. Luther on the Ave Maria: "It is no prayer; it is a formula of praise" (cited in The Pastoral Luther, 241n22: WA, 11:59-60, sermon of March 11, 1523). And cf. Thomas Taylor: "whereas salutation is to be done to a partie present among us, this saluteth one absent ..." (A commentarie upon the Epistle of S. Paul written to Titus. Preached in Cambridge [London, 1612], 747).

26. Taylor, A commentarie, 747.

27. "enterchangeable greetings": Etienne Pasquier, The Iesuites catechisme. (London: 1602), 2; "reciprocall greetings": Plutarch, The philosophie, commonlie called, the morals, trans. Philemon Holland (London, 1603), 48. Cf. John Boys: "mutuall salutations insinuate sweete agreement and love": An exposition of al the principal Scriptures vsed in our English liturgie (London, 1610), 49.

28. Marc Lescarbot, Noua Francia: or The description of that part of New France, which is one continent with Virginia (London: George Bishop, 1609), 240. Cf. Peter Martyr: "we read not, that God did salute anie man; seeing it is the propertie of him to giue helth, and not to praie for the same" (Pietro Martiri Vermigli, The Common Places of Peter Martyr, translated and partly gathered by Anthony Marten [London, 1583], 560). 
29. Derrida, Adieu, 63; cf. "Hostipitality," 14, on "the difference, the gap, between the hospitality of invitation and the hospitality of visitation. In visitation there is no door."

30. Michael Baxandall has a classic reading of her different gestures of response, which he derives from Italian dance manuals. See Painting and Experience in Fifteenth-Century Italy (Oxford: Oxford University Press, 1972), chapter 2. My thanks to Julia Lupton for pointing this out.

31. Erasmus's paraphrase of the narrative reinforces the point: "But the virgin, at the sodayne sight of the Aungell, and agayne also at the fourme and tenour of his salutacion beeyng straunge and suche as neuer had been heard of afore, forasmuche as she on her owne behalfe conceyued no great opinion of her selfe, was right muche dismayed in her minde." (Erasmus, The first tome or volume of the Paraphrase of Erasmus vpon the Newe Testamente [London: Edwarde Whitchurche, 1548], xxii).

32. Ludus Coventriae, 106.

33. Gibson, 144.

34. Subha Mukherji, “'Invasion from outer space': The Threshold of Annunciations," in Thinking on Thresholds: The Poetics of Transitive Spaces, ed. Mukherji (London: Anthem Press, 2011), 43-70, 48-49. Cf. Cleo McNelly Kearns: “The angelic greeting breaks in on the familial setting and specifics of lineage provided by the gospel with a quality of surprise. Gabriel's ave entails a recognition of mystery, of free human subjectivity in Mary herself, and not simply a recognition of her role in providing a new son for the patriline. It also entails a genuine novum, a new kind of event" (The Virgin Mother, Monotheism and Sacrifice [Cambridge: Cambridge University Press, 2008], 147).

35. Georges Didi-Huberman, Fra Angelico: Dissemblance and Figuration, trans. Jane Marie Todd (Chicago: Chicago University Press, 1995), 149; my emphasis.

36. Christopher Pye, The Vanishing: Shakespeare, the Subject, and Early Modern Culture (Durham, NC: Duke University Press, 2000), 65. Pye is implicitly drawing upon Louis Althusser's notion of hailing-as-interpellation: "All ideology hails or interpellates concrete individuals as concrete subjects" (Lenin and Philosophy and other Essays, trans. Ben Brewster [New York: Monthly Review Press, 1971], 173-4).

37. Pye, The Vanishing, 84.

38. I thank David Goldstein for bringing this point to my attention.

39. See, for example, Lescarbot (see note 28 above); and cf. "And first after his salutacion, he assureth them of saluacion" in "The Argument" of The Epistle of Paul to the Ephesians in William Whittingham, The Bible and Holy Scriptures (Geneva, 1562), Chap. II; III, 81.

40. William Phiston, The Schoole of good manners. Or, A new Schoole of Vertue, trans. W. F (London: J. Danter, for William Johnes, 1595), 15.

41. Derrida, Comment Nommer, in Le poète que je cherche à être: Cahier Michel Deguy, ed. Yves Charnet (Paris: La Table Ronde/Belin, 1996), trans. (as "How to Name") Wilson Baldridge, afterword to Michel Deguy, Recumbents, trans. Baldridge (Middletown, CT: Wesleyan University Press, 2005), 184-5.

42. Jacques Derrida, On Touching -Jean-Luc Nancy, trans. Christine Irizarry (Stanford, CA: Stanford University Press, 2005), 310.

43. Derrida, "Avances," preface to Le tombeau du dieu artisan - sur Platon, by Serge Margel (Paris: Minuit, 1995), 42n: "Mais ne peut-on se risquer à dire, sans ou 
contre Heidegger, que le salut à l'autre (Gruss) doit suspendre toute assurance ou toute promesse du salut comme ce qui sauve, dans le sauf, la salvation ou le salutaire de la santé (heilen, heilig)?" [But could it not be risked to say, without or contra Heidegger, that the salute to the other (Gruss) must suspend all assurance or all promise of health as that which saves, in the safety, salvation, or the salutariness of health (heilen, heilig [healing, holy])?].

44. Martin Hägglund, glossing Derrida in Radical Atheism: Derrida and the Time of Life (Stanford, CA: Stanford University Press, 2008), 128.

45. Derrida, Monolingualism of the Other, 68.

46. Derrida, Adieu, 19.

47. One might add to these Hamlet's "Nymph, in thy orisons be all my sins remembered" (Hamlet's salutation to Ophelia, whom he finds, Virgin Mary-like, reading a book; see Hassell, "Intercesstion”); Demetrius's "O Helena, goddess, nymph, perfect, divine! ... O, let me kiss / This princess of pure white, this seal of bliss!" (3.2); as well as, perhaps, Iachimo's entry into Innogen's bedchamber.

48. Boys, An exposition of al the principal Scriptures, 57. See Miri Rubin, Mother of God: A History of the Virgin Mary (London: Allen Lane, 2009), 376. Perhaps it is worth recalling here the "charged and expectant silence" of the N-Town Mary as a precursor to Isabella's silent response to the Duke's proposal at the end of Measure for Measure.

49. Thomas Rymer, A Short View of Tragedy (London, 1693), 111.

50. Rymer, A Short View of Tragedy, 112. He continues: "The next thing our Officer does, is to salute Iago's Wife, with this Conge to the Husband," before the "long rabble of Jack-pudden farce betwixt Iago and Desdemona."

51. Peter Milward, Biblical Influences in Shakespeare's Great Tragedies (Bloomington, IN: Indiana University Press, 1987), 101; E. A. J. Honigmann, ed., Othello (Arden Shakespeare, 1999), 107; Hassell, "Intercession," 43; see also Robert Hunter, Shakespeare and the Mystery of God's Judgments (Athens, GA: University of Georgia Press, 1976); and Neill, 172, on Cassio's "poetry of Marian adoration" in this address. See also Waldron, Reformations of the Body, on "Desdemona's Marian qualities": "In Othello, Shakespeare explores just this conception of the origins of idolatry and sacrifice in the human imagination and in the desire to merit love and grace" (20-1n38); cf. 161-3.

52. Tim Blake Nelson's 2001 film O (an updating of Othello) opens with Verdi's Ave Maria.

53. Derrida, Adieu, 16-17.

54. Again, I am indebted to David Goldstein for helping me see this point.

55. Emile Benveniste, Indo-European Language and Society, trans. Elizabeth Palmer (London: Faber and Faber, 1973).

56. Neill, Othello, 172.

57. Janet Adelman, Suffocating Mothers: Fantasies of Maternal Origin in Shakespeare's Plays, Hamlet to The Tempest (New York: Routledge, 1992), 68-69. On the association between strawberries (the handkerchief's adornment) and the Virgin Mary, see Lawrence J. Ross, "The Meaning of Strawberries in Shakespeare," Studies in the Renaissance 7 (1960), 225-40.

58. Adelman, Suffocating Mothers, 273n48 and 67.

59. Cavell, Disowning Knowledge: In Six Plays of Shakespeare (Cambridge: Cambridge University Press, 1987), 137.

60. Cavell, Disowning, 35 (cf. $126 \&$ 136). Descartes, by the way, claimed to have seen an apparition of the Virgin Mary. 
61. Boys, An exposition of al the principal Scriptures, 57.

62. Adorno, Minima Moralia, 41.

63. Note too the by-play around Cassio's greeting of Emilia; of the "courtly" kiss bestowed by the lieutenant in greeting Iago's wife, the latter says: "Sir, would she give you so much of her lips / As of her tongue she oft bestows on me, /You'd have enough" (11. 100-102).

64. The Winter's Tale, 1.2.286ff; and compare this sentiment to Othello's "May the winds blow till they have awakened death" $(2.1 .181)$ in this scene.

65. Peter Brown, The Body and Society: Men, Women and Sexual Renunciation in Early Christianity (New York: Columbia University Press, 2008), 354; he quotes Ambrose, for example: "in what does the chastity of the virgin consist, but in an integrity unexposed to taint from the outside?" Recall here "the medieval exegetical commonplace of Mary's virginity as the porta clausa" (Gibson, 154); cf. the multiplying of hospitality-spaces in the hortus conclusus, "the enclosed garden that emblemized the womb of the Virgin Mary" (Gibson, 63).

66. Eamon Duffy, The Stripping of the Altars: traditional religion in England c. 1400-c. 1580 (New Haven and London: Yale University Press, 2005), 175.

67. Jacques Derrida, "Faith and Knowledge" in Acts of Religion, ed. Gil Anidjar (New York: Routledge, 2010), 44 and 49.

68. Frye, The Secular Scripture: A Study of the Structure of Romance (Cambridge, MA: Harvard University Press, 1976), 86.

69. It is of course unclear in the play whether or not Othello is circumcised. Much has been written on this issue, but perhaps it will suffice here to suggest that our uncertainty regarding Othello's scathedness parallels our uncertainty vis-à-vis Desdemona's virginity. The issue of circumcision, and its relation to being (un) scathed, is a complex one, since the act of being circumcised at once leaves the body scathed and marks one out as being saved or elect. Perhaps one way to think of this is of a kind of displacement of the sense of being scathed.

70. Harry Berger, Jr., “Three's a Company: The Spectre of Contaminated Intimacy in Othello," The Shakespeare International Yearbook (4: Shakespeare Studies Today), ed. Graham Bradshaw, Tom Bishop, and Mark Turner (Aldershot: Ashgate, 2004), 235-63, 238. René Girard's description of the triangulation of desire in the play is subtly different-an active triangulation rather than a turning-away from the other: see A Theatre of Envy: William Shakespeare (New York: Oxford University Press, 1991), $183 \mathrm{ff}$.

71. Boys, An exposition of al the principal Scriptures, 57.

72. Anthony Stafford, The Femall Glory, 219.

73. Kenneth Burke, "Othello: An Essay to Illuminate a Method," in Kenneth Burke on Shakespeare, ed. Scott L. Newstok (West Lafayette, IN: Parlor Press, 2006), 78 (first published in The Hudson Review 4 (1951), 165-203). Cf. Freud's "On the Universal Tendency to Debasement in the Sphere of Love," SE 11, 179-90.

74. Levinas, Totality and Infinity, 82.

75. S. T. Coleridge, Writings on Shakespeare, ed. Terence Hawkes (Oakville, ON: Capricorn Books, 1959), 173.

76. Hamlet, 2.1.65. On go-betweens and skepticism, see my "Troilus and Cressida: The Worst Case of the Other," Philosophy and Literature 32, no. 1 (April 2008), 74-87.

77. On the implications of this revelation, see especially Harry Berger, Jr., A Fury in the Words: Love and Embarrassment in Shakespeare's Venice (New York: Fordham University Press, 2012), especially 87-100. Both Othello and Cassio 


\section{David Hillman}

have therefore been the recipients of Brabantio's hospitality and might be deemed to have abused it.

78. G. Wilson Knight, The Wheel of Fire: Interpretations of Shakespearean Tragedy (London: Methuen, 1930; 1961), 98, 118, 103; Burke, “Othello: An Essay,” passim; A. P. Rossiter, Angel with Horns: Fifteen Lectures on Shakespeare (London: Longman, 1961; 1989), 206, 208; Berger, “Three's a Company.”

79. Levinas, Otherwise, 150.

80. Honigmann's note at 2.1.196 SD. 


\title{
$7 \quad$ As You Like It and the Theater of Hospitality
}

\author{
James Kuzner
}

In As You Like It, the shepherd Corin criticizes his master by remarking that he "is of churlish disposition, / And little recks to find the way to heaven / By doing deeds of hospitality" $(2.4 .75-77) .{ }^{1}$ Whether any character recks to find the way to heaven by doing such deeds, scenes of hostility (between Oliver and Orlando, not to mention between Duke Frederick and just about everyone) create the play's conflicts, while scenes of hospitality (when Duke Senior invites Orlando to feast and when Rosalind invites Orlando to her cote) enable its resolutions. These scenes, we will see, are highly stylized, even theatrical in the extent to which they foreground their artifice, and in this essay I explore the play's distinctly theatrical hospitality, with an eye to its politics.

Criticism often traces the political implications of theatricality within the play-usually by considering how Rosalind's performance of gender frees or fails to free her from patriarchal strictures and grant her some measure of autonomy, or at least agential capacity, in the fashioning of her identity. ${ }^{2}$ That Rosalind shows, to a greater or lesser degree, how theatricality allows subjects to write or to own their own scripts, I would never contest. I merely want to focus on moments when characters entertain someone else's scriptwhen they welcome someone else's pretenses and play along with them irrespective of belief-in a way that has political potential. In As You Like It - to borrow from Julia Lupton's account of connections between theatricality and hospitality-being hospitable consists in helping another craft a scene in which to appear. ${ }^{3}$

This resolutely theatrical hospitality-practiced by Adam and Duke Senior in relation to Orlando, and by Orlando in relation to Rosalindoffers different political possibilities from those often found in the theatrical. In the cases of Duke Senior and Adam, theatricality seems to throw shadows over their hospitality, but attention to Orlando's willingness to play along with Rosalind casts the Duke and the old man in more generous lights. While analyses centered on Rosalind (with good reason) tend to focus on how performance frees or fails to free her from patriarchal social scripts, emphasis on Orlando shows how acceding to more marginal scripts can undo autonomy in a salutary way. In an earlier book, I detail a division in thinking about the political utility of Shakespeare. On one side of this 


\section{8}

division, Shakespeare's works have such utility insofar as they offer a vision of bounded, discrete, and empowered selfhood, and imagine vulnerability as what political activity ought to minimize. ${ }^{4}$ While As You Like It certainly can be read along these lines, I wish to focus on how vulnerability-in this case to the fantasies that others have about themselves—can be virtue.

Without question, the feigned, hedged hospitality of As You Like It is unlike the radical, infinite hospitality that, as I point out later, fascinates Derrida: a total, unconditional, dangerous openness in advance of any other. Readers have long acknowledged that Arden's dangers distance it from Arcadia, yet the forest is commodious and comic enough that infinite hospitality appears there only to disappear, as risk dissolves in fellow feeling. Arden calls for a hospitality that, in its performativity, is of a more quotidian order than that imagined by Derrida. All the same, this ordinary, finite hospitality helps us to think through a problem of political life and of everyday living: of how to be hospitable when we don't mean it, when the best we can do is play along. ${ }^{5}$

\section{Welcome to Our Table: Duke Senior}

In act 2, scene 7, Duke Senior, Jaques, and some lords are gathered together for fellowship when Orlando, desperate to find food for Adam, bursts upon the scene sword in hand. What stands out most to me in the exchange that follows is the composure, even the calm with which the ducal company receives the armed man. Neither Jaques nor Duke Senior, for instance, register any distress; when Orlando commands them to "eat no more" (2.7.88), Jaques, ever a stickler, points out that he in fact has not eaten at all, while the Duke inquires coolly as to whether distress or just poor breeding accounts for Orlando's boldness. When their intruder indicates that it is the former, the Duke observes that "[y]our gentleness shall force / More than your force move us to gentleness" (2.7.101-102), but for now Orlando would rather just force with force: "I almost die for food," he says, "and let me have it" (2.7.103). Despite the advice just given—and despite Orlando still brandishing his sword-the Duke invites the intruder to dine ("Sit down and feed, and welcome to our table" [2.7.104]), abandoning the rule he has just set as to the behavior admissible in his forest abode. If Orlando feels the need to commandeer food at sword-point, so be it. With hospitality that appears infinite, the Duke welcomes a declared, armed enemy. I say "infinite"-rather than, for example, "astonishing"- -because the Duke's openness conjures the pure hospitality outlined by Derrida: "Pure and unconditional hospitality," he writes,

hospitality itself, opens or is in advance of someone who is neither expected nor invited. ... this is a hospitality of visitation rather than invitation. The visit might actually be very dangerous, and we must not ignore this fact, but would a hospitality without risk, a hospitality backed by certain assurances, a hospitality protected by an immune system against the wholly other, be true hospitality? ${ }^{6}$ 
Like Derrida's unconditional hospitality, the forest scene just described is one of visitation, not invitation; the Duke and his company at first have no assurance that their unexpected visitor will not slit their throats once he has his victuals. It is true, we should note, that Duke Senior attempts to convert an unconditional visitation (by which Orlando is to take under threat of violence) into a conditional invitation (by which Orlando is to partake so long as he is gentle), such that the Duke's discourse at first resembles not hospitality so much as tolerance. "Tolerance," Derrida writes,

remains a scrutinized hospitality, always under surveillance, parsimonious and protective of its sovereignty ... ("I invite you, I welcome you into my home, on the condition that you adapt to the laws and norms of my territory, according to my language, tradition, memory, and so on"). ${ }^{7}$

Still, Duke Senior's conditional invitation sheds its condition almost immediately. Orlando can bring the sword to table, for all that present company cares, as the finite becomes the infinite, the hedged and protected the open and exposed.

But then the danger dissolves and Orlando sheathes his sword. Grasping the unconditional nature of the Duke's hospitality, he wants the initial condition restored. "Let gentleness my strong enforcement be," he pleads. "I blush, and hide my sword" (2.7.117-118). Paul Kottman argues that Shakespeare poses fundamental questions about attachment by way of Arden. "What forms of human attachment might survive the disappearance of all preexisting social, familiar, or political bonds?" Kottman asks. "Can any form of human attachment or 'affection' uphold itself-provide for itself a future-fully independent of the preexisting social, or familial, or cultural dimensions that might sustain and facilitate such an attachment?" 8 By his own virulence, Orlando suddenly faces this question. With no answer, he insists on gentility, remaking the bond that he himself has broken.

Duke Senior seems pleased: "therefore sit you down in gentleness" (2.7.123). Repetitive gestures toward the gentle are risible by this point, particularly when compared with one of Shakespeare's sources, Lodge's Rosalynde, which resolves the issue without negotiation. ${ }^{9}$ All the same, Duke Senior reminds Orlando, indirectly, that "gentlemen only" is only a pretense and that there is not really any condition of entry: "take upon command what help we have / That to your wanting may be ministered" (2.7.124-125). Orlando has sought to command the Duke, and now is commanded by the Duke to command what they have. Orlando can behave as gently and as deferentially as he wishes, but as far as the Duke's hospitality goes there is little difference between commanding and being commanded, being Duke Senior and being Orlando. Openness again appears infinite. Given this-that the Duke happily removes the one condition on which his hospitality hinges, then is willing, simply to please his guest, to pretend that 
he does demand gentleness after all-he might strike us as a definite center of value. As You Like It presents a world where being a villain consists in being inhospitable, as we see when Oliver refuses to welcome his own brother on any condition, and when Duke Frederick banishes practically everyone. Duke Senior sparkles against this background, figuring what Derrida deems impossible: hospitality that is truly without condition.

And yet, at least for me, the scene is unconvincing as an instance of infinite welcome. Perhaps this is because Jaques and the Duke themselves seem unconvinced by Orlando's show of violence, which in turn makes the Duke's willingness to risk himself less than wholehearted. Say Orlando's blade was at Duke Senior's throat-would the Duke still, in composed whispers, invite the sword-bearer to sit and feed? ${ }^{10}$ The repeated insistences on gentleness bloat the exchange, stretch it with pretense, and the threat that seems not really a threat makes the unforced quality of the Duke's hospitality seem, well, forced, expressed uncompellingly. When we hear that "[m]ost friendship is feigning" (2.7.179), in a scene where all seems feigned, it is indeed not easy to imagine how genuine friendship would appear. As Orlando exits to fetch Adam, the Duke seems to acknowledge the stilted, theatrical nature of the exchange, or at least to conceive of acting and living in terms of performing and playing:

Thou see'st we are not all alone unhappy:

This wide and universal theatre

Presents more woeful pageants than the scene

Wherein we play in.

Jaques responds with his famous speech in which all the world is a stage. Though he has asked for unlimited critical license-for "as large a charter as the wind, / To blow on whom I please" (2.7.48-49)—he does not criticize the Duke. Instead, his speech, which labels all human endeavor as theatrical, works to preempt my reservations about the exchange we have just seen. Orlando carries Adam onto stage just after Jaques describes life's "last scene," "Sans teeth, sans eyes, sans taste, sans every thing" (2.7.165), and this picture of embodied suffering - of what cannot be feigned or performed but simply is-would seem a sharp riposte to Jaques's sweeping claim, ${ }^{11}$ were it not the case that artifice also suffuses the moment of Adam's reception:

DUKE SENIOR: Welcome. Set down your venerable burden.

And let him feed.

ORLANDO: I thank you most for him.

ADAM: So had you need;

I can scarce speak to thank you for myself. 
Adam speaks to assure the Duke that he can scarcely speak-quite remarkable given how laconic he is earlier in act 2, as he resolves to measure out his grave. What could make an otherwise unconvincing scene into a moment of arresting attention and care instead calls attention to its own artifice: to how starvation itself, once it enters the Duke's orbit, comes to seem performed. ${ }^{12}$

There is nothing out of the ordinary in the mere fact that all seems performed. Erving Goffman writes that "ordinary social intercourse is itself put together as a scene is put together, by the exchange of dramatically inflated actions, counteractions, and terminating replies.... All the world is not, of course, a stage, but the crucial ways in which it isn't are not easy to specify." 13 What is out of the ordinary, I would argue, is the unconvincing quality of the performance. Goffman also writes that " $[\mathrm{w}]$ hen an individual plays a part he implicitly requests his observers to take seriously the impression that is fostered before them," and while Orlando requests as much at first, no one-save Orlando himself-takes any impression very seriously. ${ }^{14}$ The scene's wide theater of hospitality swallows up a sense of the infinite. ${ }^{15}$

\section{Go on, and I Will Follow Thee: Adam}

Adam seems a more apt figure of unconditional—or, at least, genuinehospitality, as he gives Orlando so much place as to leave none for himself. As it happens, Adam's first hospitable act is to warn Orlando away from a site (his brother Oliver's estate), not to welcome him to it: "Come not within these doors" (2.3.17) he counsels after Orlando foils his brother's plan to break his neck. If, as Yi-Fu Tuan puts it, "[p]lace is security," Adam rightly declares that "[t]his is no place" (2.3.27); Oliver's house has all of the risks that come with what Tuan would call space (rather than place), and none of the freedoms. ${ }^{16}$ Orlando replies that he can find no welcome elsewhere and that he is not about to become a beggar, but Adam has a solution: he gives Orlando five hundred crowns, his life savings, and even offers to accompany his master-averring that he, though nearly eighty, is in top physical condition. Adam impresses Orlando with his noninstrumental offer, with the fact that he sweats for duty, not for "meed" (2.3.58), and the old man's next response reveals the stakes for him in joining Orlando:

ADAM: Master, go on, and I will follow thee

To the last gasp with truth and loyalty.

From seventeen years till now almost fourscore

Here lived I, but now live here no more.

At seventeen years many their fortunes seek,

But at fourscore it is too late a week.

Yet fortune cannot recompense me better

Than to die well and not my master's debtor. 


\section{2}

For his master's sake, Adam relinquishes not just his life savings but his life, the six decades that he has spent at the de Boys estate. Adam gives up everything for Orlando-in rhymes that emphasize the importance of preserving Orlando (thee / loyalty) and his own impending annihilation (fourscore / no more)—so it is no surprise that the next time Adam appears, he, despite his protestations of health, resolves to measure out his grave: "Dear master, I can go no further. O, I die for food! Here lie I down, and measure out my grave. Farewell, kind master" (2.6.1-3). Like Celia earlier, Adam says that he is spent, but he does not just need a break. He is starving — and evidently has waited until he is ready to expire to say so. Yet Adam manages to begin and end what he takes to be his dying speech with terms of endearment ("Dear master ... kind master"). What self-sacrifice and unsurpassed hospitality, we might say: what welcome, openness, and attention to Orlando at his own expense. What hospitality that, in being total, has lost its hearth.

Adam measuring out his own grave seems especially impressive when we measure the distance separating him from the Adams of Shakespeare's sources. Shakespeare's Adam differs radically from the Adam of The Tale of Gamelyn - who agrees when Gamelyn (a source for Orlando) begs to be freed from the chains in which his brother has put him, but only "[i]n hope of avauncement," only because Gamelyn has offered him land. ${ }^{17}$ When the Tale's Adam struggles in the wilderness, he hardly accepts it as in Shakespeare: "By Seint Richere," he laments, "Now I see it is mery to be a spencere, / Yit lever me were kayes to bere, / Than walken in this wilde wode my clothes to tere" (614-617). Even the more virtuous Adam that we meet in Lodge's Rosalynde struggles between his concern for himself and for Rosader when provisions run short. At first he falls into "bitter tearmes," claiming that "all our pleasures ende in paine, and our highest delights, are crossed with deepest discontents." He then corrects himself- "why ADAM doost thou exclaime against fortune?"- and resolves to die not just because he can no longer help Rosader, but also because he cannot bear to behold his master's distress:

Ah ROSADER, could I helpe thee, my griefe were the lesse, and happie should my death be, if it might be the beginning of thy reliefe: but seeing we perish both in one extreame, it is a double sorrowe. What shall I do? preuent the sight of his misfortune, with a present dispatch of mine owne life. Ah despaire is a mercilesse sinne.

Before despair can issue in self-killing, Rosader himself complains about the prospect of dying of starvation rather than of battle wounds, and this provokes a thought in Adam:

Master (quoth hee) you see wee are both in one predicament, and long I cannot liue without meate, seeing therefore we can finde no foode, let the death of the one preserue the life of the other. I am olde, and ouerworne with age, you are young, and are the hope of many honours: let 
me then die, I will presently cut my veynes, \& master with the warme bloud reliue your fainting spirits: sucke on that till I ende, and you be comforted.

Lodge's Adam is about to pull out his knife when Rosader, newly infused with courage, objects in favor of foraging. Shakespeare's Adam registers none of this bitterness or conflict, simply remarking that the time has come to measure out his grave. While this has partly to do with issues of genre and length, Shakespeare might also seem particularly intent on presenting Adam as a figure of pure sacrifice. Shakespeare's Adam, unlike Lodge's, cannot even imagine his death as benefiting Orlando; neither despairing nor freighting his death with significance, he cedes his interests entirely to his master's.

Except Orlando will not accept the sacrifice:

Why, how now Adam? No greater heart in thee? Live a little; comfort a little; cheer thyself a little. If this uncouth forest yield anything savage, I will either be food for it or bring it for food to thee. Thy conceit is nearer death than thy powers. For my sake be comfortable; hold death awhile at the arm's end. I will be here with thee presently; and if I bring thee not something to eat, I will give thee leave to die; but if thou diest before I come, thou art a mocker of my labour. Well said! thou look'st cheerly; and I'll be with thee quickly.

Orlando promises to sacrifice himself if need be, to die for Adam rather than the other way around. He even indicts Adam for histrionics— "Thy conceit is nearer death than thy powers"-and claims that if Adam dies before he returns, the old man does so willingly, even aggressively, mocking his master. If Adam wants to sacrifice himself, he better not do so before Orlando gets back. Dying then is not dying well. This may well be Orlando's attempt at stern humor; but it, too, makes Adam's possible sacrifice appear less real.

Adam says nothing before Orlando exits; he merely "look'st cheerly," if Orlando is to be believed. (And perhaps he is not, speaking as he does for an old man-“Well said!"-who has said nothing.) Still, like Duke Senior, he accepts Orlando's terms, at least tacitly, even if he neither agrees nor disagrees about the values in question. This leaves readers wondering whether they should be on Adam's side or his master's. First, just on the basis of the title, we have to be on Orlando's; this is not The Winter's Tale, characters cannot die for others' redemption. When Orlando tells Adam that he would mock his labor by dying, the speaker might as well be Shakespeare (even though Shakespeare might well have played the role of Adam!). ${ }^{18}$ The old man can fade into figural oblivion, certainly, but he cannot upstage the comedy by marking out his grave onstage. Second, as we soon see in act 2, scene 7, Adam is not at death's doorstep, if he ever set foot on it within Arden. Third, even were he at death's doorstep, the text seems to suggest, who, possessing even a shred of sensibility, would 
accept hospitality as unlimited as Adam's? Accepting five hundred crowns is one thing; accepting an unmarked grave for the one who gave you the crowns is rather another. Adam's terms become a burden, which he might realize were he not caught up in histrionics: in feigning death throes, announcing that he intends to measure out his grave, and, then, when the measurements appear premature, that he lacks the speech to give thanks for the food that keeps him going. (In this if in almost no other respect, Adam shares with Hamlet: "I am dead, Horatio ... Horatio, I am dead ... O, I die, Horatio.”) Adam's total openness to Orlando, like the Duke's, seems less than genuine, so that the best we can say is that Adam accepts Orlando's heroic pretenses, much as Duke Senior welcomes Orlando's waffling about whether he is violent or gentle. Twice now the play's foregrounding of artifice draws attention to hospitality's theatricality, to how it is not pure but put on, so much so that Shakespeare's view of Arden's hospitalities seems cynical—until, that is, we encounter Orlando and Rosalind's courtship, which allows us to see significance in these hospitalities that, from a Derridean perspective, appear so hollow.

\section{Every Day to the Cote: Orlando}

Through his portrayals of Adam and Duke Senior, As You Like It implies, as does Derrida, the impossibility of pure hospitality. But Shakespeare does not stop here. There is another-a limited yet legitimate-hospitality in the play, one that we can glimpse in Orlando's relation to Rosalind, a glimpse that reorients our perspectives on Duke Senior and Adam.

Marjorie Garber has shown how Rosalind's education of Orlando allows him to grow as a lover, to move from Petrarchism's crypto-narcissism to something like actual other-concern. ${ }^{19}$ Orlando also, I want to argue, grows in his potential to be hospitable, to extend a kind of welcome. His growth begins as early as act 3, scene 2 when Rosalind, disguised as Ganymede and wishing to probe and test Orlando's love, first convinces him to undergo treatment for lovesickness. Rosalind claims expertise in detecting love melancholy's symptoms, none of which Orlando presents. Far from "demonstrating a careless desolation," Orlando is "rather point-device in your accoutrements, as loving yourself than seeming the lover of any other" (3.2.353-362). Orlando objects, exhibiting as evidence the facts that he has defaced Arden's trees with praise for his beloved and that "[n]either rhyme nor reason can express how much" he loves his Rosalind (3.2.373). She, seeing that Orlando speaks strictly in clichés, claims that "[1]ove is merely a madness" (374) and that counsel can be its cure, but Orlando wants to play the game of love as he has played the games of foraging and friendship: on his terms, not someone else's. Then, in an exchange worth examining, he suddenly agrees to Rosalind's proposal:

ORLANDO: I would not be cured, youth.

ROSALIND: I would cure you, if you would but call me Rosalind and come every day to my cote and woo me. 
ORLANDO: Now, by the faith of my love, I will. Tell me where it is.

ROSALIND: Go with me to it, and I'll show it you; and, by the way, you shall tell me where in the forest you live. Will you go?

ORLANDO: With all my heart, good youth.

ROSALIND: Nay, you must call me Rosalind.

Come, sister, will you go?

Why does Orlando change his position so rapidly? Is he not as head over heels as his poems suggest? Does he see through Ganymede's disguise, or does he just decide that coming to the cote would be a gamesome way to pass the time? I am not sure that these questions are answerable, nor, for the purposes of this essay, that they require answering. ${ }^{20}$ However we answer them, what we must observe is how the interaction differs from those that we have covered so far. We have seen Duke Senior accept Orlando's pretenses- that the threat of violence is real, that Orlando is gentle nevertheless-without believing them. We have seen Adam do the same in allowing his master to fancy himself a hero. But here Orlando accepts Rosalind's pretenses. In a literal sense, Orlando will go to Rosalind's cote and be her guest; she will welcome him. In accepting her anti-Petrarchan pretenses rather than demand that she accept his Petrarchan ones, though, Orlando welcomes Rosalind, entertains her. Lupton, as I noted earlier, writes that hospitality shares with theatricality in that both craft "scenes for appearing." ${ }^{21}$ In agreeing to Rosalind's game, Orlando helps her craft a scene in which she might appear, not as a Petrarchan ideal-a "paper paragon," as Garber puts it-but as "a woman of complexity, wit and passion." 22 The guest, in this sense, is the host.

Orlando plays along even though, presumably, he cannot believe that Ganymede will convince him that love is mere madness. Yet in accepting her pretenses, he comes to adopt a less pretentious view of love. When she claims - in the guise of Ganymede-as-Rosalind - that she will not have him, Orlando replies that " $[\mathrm{t}]$ hen, in mine own person, I die" (4.1.81), but Rosalind denies that anyone has died for love:

No, faith, die by attorney. The poor world is almost six thousand years old, and in all this time there was not any man died in his own person, videlicet, in a love-cause. Troilus had his brains dash'd out with a Grecian club; yet he did what he could to die before, and he is one of the patterns of love. Leander, he would have liv'd many a fair year, though Hero had turn'd nun, if it had not been for a hot midsummer-night; for, good youth, he went but forth to wash him in the Hellespont, and, being taken with the cramp, was drown'd; and the foolish chroniclers of that age found it was-Hero of Sestos. But these are all lies: men have died from time to time, and worms have eaten them, but not for love. 
Troilus had a death wish; Leander died due to cramps; only through fabrications can we imagine that a man might actually die for love. While this seems merely a withering critique of lovesick rhetoric, Rosalind's position cannot be that love should be free of pretense, but must be that love should be free of certain pretenses and of a certain approach toward pretense. Just as Orlando regards Adam's supposedly infinite, self-sacrificing hospitality as a mere pretense, so now Rosalind regards the pretense of dying for love as emptily pretentious, as undermining love rather than confirming it. Orlando accepts Rosalind's pretenses (for instance, that turning up an hour late for one of their sessions constitutes a serious offense) and in time sets aside his own (for instance, that being denied by Rosalind is fatal). I do not mean to suggest that Rosalind has access to "truth" that Orlando must accept wholesale; though it is tempting to regard her as shattering the false conceits of love to disclose what is real, her categorical claim-that no one in six thousand years has died for love-strains credulity. ${ }^{23}$ Orlando himself objects, even ups the ante: "I would not have my right Rosalind of this mind," he says, "for, I protest, her frown might kill me" (4.196-197), but when Rosalind insists that Orlando is wrong ("it will not kill a fly" [41.1.98]), he does not press the point. He plays along. In so doing here and elsewhere, he affords Rosalind an opportunity to appear as a flesh and blood beloved, and prevents himself from disappearing in love's platitudes. Eventually Orlando tires of the game they play- "I can live no longer by thinking" (5.2.48), he declares after Oliver and Celia fall for each other-at which point Rosalind asks him to accept a final pretense:

ROSALIND: Believe then, if you please, that I can do strange things: I have, since I was three year old, conversed with a magician, most profound in his art and yet not damnable. If you do love Rosalind so near the heart as your gesture cries it out, when your brother marries Aliena, shall you marry her. I know into what straits of fortune she is driven, and it is not impossible to me, if it appear not inconvenient to you, to set her before your eyes tomorrow, human as she is, and without danger.

ORLANDO: Speak'st thou in sober meanings?

ROSALIND: By my life, I do, which I tender dearly, though I say I am a magician: therefore, put you in your best array, bid your friends, for if you will be married tomorrow, you shall, and to Rosalind, if you will.

$(1.1 .49-70)$

Rosalind-as-Ganymede asks more of Orlando here than she has hitherto. She claims that she can do strange things; that she has conversed with a magician from the age of three; that she herself is a magician; that Rosalind is in "straits of fortune" yet can appear "without danger." She offers to marry him to Rosalind and asks him to believe she can do this all "if you please." Her hedging and equivocation do not inspire confidence, yet Orlando agrees, commits himself to her scheme: this, despite the fact that, as he says to Duke 
Senior, "I sometimes do believe and sometimes do not, / As those that fear they hope and know they fear" (5.4.3-4). ${ }^{24}$ In a fearful hope, Orlando only half believes what Rosalind says but plays along anyway; again, this time literally, he helps craft a scene in which she might appear. It is not too much to say that for Orlando playing along is hospitality: bidding welcome to the other's pretenses, giving the other the (forest) floor, being willing to play the other's game patiently so that the other might disclose herself.

If playing along can be thought to constitute hospitality, we can also cast a more generous eye on Duke Senior and Adam's relation to Orlando. ${ }^{25}$ Consider the objections I raised about the histrionic contexts of their hospitality: that Orlando's threat is unconvincing, that Adam is not quite on the threshold of death that he claims to have reached. If infinite hospitality is our standard, Adam and the Duke look meretricious, purporting to put themselves at greater risk than they truly do. This discrepancy, between apparent and actual risk, invalidates their hospitality. Yet if we attend to how these pretenses enable Orlando, how they allow him to form and sustain a therapeutic view of himself-how, in this, Duke Senior and Adam help him craft a scene in which to disclose himself-our estimate alters. In allowing Orlando to reassert his gentility and to save a man who says he is dying, they welcome him to appear in a way that renovates his self-conception. When Orlando learns willingness to accept Rosalind's pretenses, likewise, she not only has a chance to appear outside Petrarchan confines. He, too, develops a more flexible, dynamic form as a lover.

\section{Conclusion}

In waiting until act 3 to reveal the value of Adam and Duke Senior's earlier hospitalities, Shakespeare chastens readers (or, at least, this reader) for dismissing them as less than infinite. What sort of politics could be implied by this refusal to dismiss the theatrical and the finite? To address the question we might consider Derrida again, and particularly the distinction, mentioned earlier, between the infinite and the merely tolerant. Derrida posits alternatives: radical, unconditional, risky hospitality on the one hand, and, on the other, conservative, conditional, hedged tolerance. Glossing Levinas, Derrida goes so far as to consider the proposition that "hospitality is infinite or it is not at all." ${ }^{26}$ In As You Like It's theater of hospitality these alternatives overlap; hedged hospitality has its risks and we lack warrant to draw the "rather abrupt conclusion" about the inseparability of the infinite and the hospitable. ${ }^{27}$ First, Adam, Duke Senior, and Orlando's hospitality is not particularly perilous, but accepting someone else's pretenses always involves an element of risk; Orlando could kill Duke Senior, Adam might not die well in adventuring through Arden while pushing eighty. Second, Adam and Duke Senior welcome Orlando, and Orlando welcomes Rosalind, with something other than the sort of tolerance that would stipulate that the one welcomed must adapt to one's own protocols. As we have seen, Duke 
Senior imposes a condition (that gentleness is what sways) only to remove the condition; rather than insisting on the norms of his territory, he instead allows Orlando to de-territorialize Arden and demand food at sword-point, and when Orlando wants to rezone Arden as a place of gentleness, the Duke accedes. Adam for his part gives up familiar territory altogether, while Orlando sets aside the Petrarchan ideas framing so fundamental an idea as love. Derrida leaves us with an unpleasant pair of hospitalities: the infinite, which no one can achieve, and tolerance, which is not really hospitality at all. When I try to read As You Like It in Derridean terms, on the other hand, I end up rebuked, shown that hospitality can be finite-indeed, paradoxically, can be put on-and yet be genuine.

In Arden we do not find the infinite hospitality that, as some critics have shown, might be found in some of Shakespeare's more tragic worlds. ${ }^{28}$ The comic hospitality of As You Like It lends itself more to quotidian concernsto how, for example, we respond to the upset drunk who embroils a dinner party, to the friend who insists that we need saving when we might prefer the dignity of being left alone, to the partner (or possible partner) who believes we do not love rightly or at all. As You Like It suggests that entertaining the trying person's pretenses, helping construct the space in which they and their positions might appear, is worth our while. Good might come when we behave as though the partygoer has, in fact, every right to be upset, or as though we fail to understand love, or do need saving after all: when we behave as if these things are true regardless of whether we believe them to be so. ${ }^{29}$

Playing along means relinquishing our sense of ourselves as sovereign and self-determining, insulated from others' pretenses and free to assume our own: to, as Goffman would put it, project a definition of our situation as we see fit. ${ }^{30}$ Alexander Leggatt argues that the play champions "an imaginative freedom to explore ideas and play roles-on one's own terms, and for one's own amusement." ${ }^{31}$ While I agree-especially when it comes to the relatively liberating effect that role-playing has for Rosalind-the play also, I think, champions role-playing on another's terms, for another's amusement. To be sure, playing along can point to radically different futures, some more exciting and full of possibility than others. Adam vanishes from the play equivocally; he does not die well, as he hopes to do, and indeed does not do anything at all. Duke Senior, for his part, is restored to his former, sovereign position; accepting Orlando's pretenses-yielding to an inferiordoes not change his ducal horizon. ${ }^{32}$ Even more important: playing along in Arden can make its world more conservative. Many critics point out that Rosalind, having spent much of the play in (at least arguably) productive role-playing on her own terms, ${ }^{33}$ submits to patriarchal scripts in the end $;^{34}$ after arranging and orchestrating the final scene, she declares that she belongs to Duke Senior as a daughter and to Orlando as a wife. ${ }^{35}$ No theater of hospitality could eliminate relations of power, and As You Like It's end suggests that playing along can be constraining rather than expansive. Harold Jenkins shows how in Arden every position finds its opposite, and 
the position this essay describes finds its opposite in the play's final scene. ${ }^{36}$ Rosalind, who has not been my focus, shows how at times theatricality can and should serve strategic, self-interested purposes, reversing power relations and helping those in weaker positions to achieve their ends.

But at other times, as in Orlando's case, playing along has value. A cynical reading, one in which he sees through Rosalind's disguise from the beginning, might maintain that Orlando is strategic all along, that he plays along only in hopes that Rosalind will be his, elevating him from the Petrarchan lover's relatively impotent role to a husband's more powerful one. Such a reading, though, lacks the textual support that we can find to argue that Orlando opens himself to a more flexible view of love, one that is less Petrarchan and less one-sided and that comes to involve dynamic interaction and mutual understanding. Jon Erickson argues that in theatricality we see the productive interplay of two kinds of action as defined by Habermas: the strategic (that is, the self-interested, the dissembling and the manipulative), and the communicative (that is, the mutually interested, open, and coercion-free). ${ }^{37}$ In the scenes before their marriage, Orlando and Rosalind's theater of hospitality shows this interplay. Dissembling and manipulation are everywhere; Rosalind conceals her identity when welcoming Orlando to her cote, hoping to whip Petrarch out of him without ever administering the promised cure, while Orlando means not to be cured even as he cedes to treatment. Yet neither quite coerces the other and something like mutuality, at least for a time, emerges; Orlando and Rosalind develop a working understanding of each other and of love. ${ }^{38}$ They have a chance to play with power and, in the process, to craft a scene that sustains their affection. ${ }^{39}$ Playing along has its problems. Yet amid them-amid this theater of hospitality that they don't really mean-the two craft new meaning, new love, new life.

\section{Notes}

1. All references to the play are to As You Like It, ed. R. B. Kennedy and Mike Gould (London: Harper Press, 2011).

2. Criticism that considers the relation of the political to the theatrical I cite later. For an example of a recent essay that considers theatricality in a less political sense, see P. H. Parry, "Visible Art and Visible Artists: Reflexivity and Metatheatricality," Forum for Modern Language Studies 34, no. 1 (1998): 1-15.

3. See Julia Reinhard Lupton, "Hospitality," in Early Modern Theatricality, ed. Henry Turner (Oxford: Oxford University Press, 2013), 423-41, esp. 423.

4. See James Kuzner, Open Subjects: English Renaissance Republicans, Modern Selfhoods, and the Virtue of Vulnerability (Edinburgh: Edinburgh University Press, 2011), esp. 84-124.

5. See D. J. Palmer for an older account of the possibilities of play in As You Like It. Palmer, “As You Like It and the Idea of Play," Critical Quarterly 13, no. 3 (1971): 234-46.

6. See Philosophy in a Time of Terror: Dialogues with Jürgen Habermas and Jacques Derrida, interviewed by Giovanna Borradori (Chicago: University of 
Chicago Press, 2003), 129. For other of Derrida's reflections on hospitality, see Adieu to Emmanuel Levinas, trans. Pascale-Anne Brault and Michael Naas (Stanford: Stanford University Press, 1999), and Of Hospitality, trans. Rachel Bowlby (Stanford: Stanford University Press, 2000).

7. Borradori, Philosophy in a Time, 129.

8. Paul Kottman, Tragic Conditions in Shakespeare: Disinheriting the Globe (Baltimore: Johns Hopkins University Press, 2009), 33.

9. In Lodge, Rosader [a source for Orlando] "stept boldly to the boords end, and saluted the companie thus. Whasoere thou bee that art master of these lustie squiers, I salute thee as graciously, as a man in extreame distresse may; knowe that I and a fellow friend of mine, are heere famished in the forrest for wante of foode: perish we must vnlesse relieued by thy fauours. Therefore if thou be a Gentleman, giue meate to men, and to such men as are euerrie way worthie of life; let the proudest squire that sittes at thy table, rise $\&$ incounter with me in anie honourable point of actiuitie what soeuer, and if he and thou proue me not a man, send me a way comfortlesse. If thou refuse this, as a niggard of thy cates, I will haue amongst you with my sword; for rather will I die valiantly, than perish with so cowardly an extreame. GERISMOND [a source for Duke Senior] looking him earnestly in the face, and seeing so proper a Gentleman in so bitter a passion, was mooued with so great pitie, that rising from the table, he tooke him by the hand and bad him welcome, willing him to sit downe in his place, and in his roome not onely to eate his fill but be Lorde of the feast." See Rosalynde (London: 1590), 33.

10. As C. L. Barber puts it, in Arden we encounter a "human situation which makes conflict seem for the moment superfluous," which certainly seems the situation of Duke Senior and Orlando. Barber, "The Alliance of Seriousness and Levity in As You Like It," in William Shakespeare's As You Like It, ed. Harold Bloom (New York: Chelsea House, 1988), 5-21, esp. 7.

11. For a few examples of criticism that see the entrance of Orlando bearing Adam as undercutting Jaques, see Wendell Berry, "The Uses of Adversity," Sewanee Review (2007): 211-38, esp. 221; Harold Bloom, Shakespeare: The Invention of the Human (New York: Riverhead Books, 1998), 216; and Thomas McFarland, "For Other Than for Dancing Measures: The Complications of As You Like It," in William Shakespeare's As You Like It, 23-45, esp. 34.

12. This means that I am not persuaded by readings that see the feast as grave with significance. See, for instance, Andrew Barnaby, "The Political Conscious of Shakespeare's As You Like It," Studies in English Literature 36 (1996): 373-95. Barnaby writes that " $[\mathrm{t}]$ he meal, reimagined as a Sabbath-day feast, symbolizes the restoration of social communion especially as this is founded on those culturally sustaining lines of authority in which servants and masters properly recognize each other with reciprocal "truth and loyalty"' (386).

13. Erving Goffman, The Presentation of Self in Everyday Life (Garden City: Anchor Books, 1959), 72. Interestingly, in his later Frame Analysis: An Essay on the Organization of Experience (Boston: Northeastern University Press, 1986), Goffman claims that "[a]ll the world is like a stage" (124).

14. Goffman, The Presentation of Self, 17.

15. For a fascinating, alternative reading of the scene, see David B. Goldstein, who argues that "[t]he al fresco banquet of As You Like It uncovers a moment in which food, eating, and hospitality force all characters involved to play 
themselves rather than to play whatever role they feel themselves bound to play. The scene is an exercise in playing well and properly, as opposed to the more troubled, straitened playing of the first act, and it sets the stage (so to speak) for the experiments in playing that follow." Goldstein, "Eats Well With Others: Culinary Experience in As You Like It and Montaigne's 'Of Experience'," in Levinas and Shakespeare, ed. Kent Lehnhof et al. (New York: Fordham University Press, forthcoming).

16. Yi-Fu Tuan, Space and Place: The Perspective of Experience (Minneapolis: University of Minnesota Press, 1977), 3.

17. See "The Tale of Gamelyn," in Robin Hood and Other Outlaw Tales, ed. Stephen Knight and Thomas H. Ohlgren (Kalamazoo: Western Michigan University Press, 1997), 414.

18. See Bloom, Shakespeare: The Invention of the Human, 205.

19. Marjorie Garber, "The Education of Orlando," in Comedy from Shakespeare to Sheridan: Change and Continuity in the English and European Dramatic Tradition, ed. A.R. Braunmuller and J.C. Bulman (London: Associated University Presses, 1986), 102-12. Garber argues that Rosalind transforms Orlando "from a tonguetied boy to an articulate and (relatively) self-knowledgeable husband" (112).

20. There is some division among critics as to whether Orlando sees through Rosalind's disguise. Garber, for instance, argues that "Orlando ... has his mind wholly on Rosalind, yet he does not see her as she stands before him" ("The Education of Orlando," 107). Thomas McFarland, likewise, writes that Shakespeare "grants the audience an insight immensely superior to that of Orlando, while equating his exaggerated love with his ignorance" ("For Other Than for Dancing Measures," 41). Bloom, by contrast, writes that "[a]side from straining credulity, it would be an aesthetic loss if Orlando were not fully aware of the charm of his situation" (Shakespeare: The Invention of the Human, 221).

21. Lupton, "Hospitality," 424.

22. Garber, "The Education of Orlando," 109.

23. Palmer argues that Rosalind herself does not believe, or at least does not want to believe, her own assertion, given "the pause and a light change of tone" at the end of the speech: "One can almost detect a certain wistfulness in the dying fall of the conclusion, 'but not for love', as though Rosalind sighs behind "Ganymede"s back" ("As You Like It and the Idea of Play," 241).

24. Richard McCoy, building on Coleridge, sees acceptance of feigning as central to the good life as the play presents it: "Happiness in As You Like It seems to require a jolly acceptance of feigning and folly. Feigning and folly are inescapable in the Globe and the world beyond, and the play shows us how to make virtues of these presumed liabilities." McCoy, "As You Like It and Believing If You Please," in Faith in Shakespeare (Oxford: Oxford University Press, 2013), 53-81, esp. 59.

25. Cf. Goldstein, "Eats Well with Others," for the relevance of Montaigne's idea of "playing the human well" to hospitality in the play.

26. Derrida, Adieu to Emmanuel Levinas, 48.

27. Ibid.

28. See, for instance, Thomas P. Anderson's essay for this volume. I myself have written along similar lines in "'And here's thy hand': Titus Andronicus in a Time of Terror," in Shakespeare After 9/11, ed. Matthew Biberman and Julia Reinhard Lupton (Lewiston: Edwin Mellen Press, 2011), 191-201. 
29. Helen Gardner writes that at the center of As You Like It we find the "discovery of truth by feigning, and of what is wisdom and what folly by debate," and while this is true to an extent, my argument entails that feigned hospitality has intrinsic value quite apart from any discovery of truth. Gardner, "As You Like It," in More Talking of Shakespeare, ed. John Garrett (London: Longman, Green and Co., 1959), 17-32, esp. 28.

30. Goffman, The Presentation of Self, 1-16.

31. Alexander Leggatt, Shakespeare's Comedy of Love (London: Methuen \& Co., 1974), 191-2. Ruth Nevo, likewise, describes the play as "a liberating playful fantasy." Nevo, "Existence in Arden," in William Shakespeare's As You Like It, 63-79, esp. 64.

32. Having said this, I am inclined to agree with Linda Woodbridge that " [i]t doesn't matter what kind of ruler Duke Senior was and will be," that "the play loses interest in that, and directs our attention elsewhere." See "Country Matters: As You Like It and the Pastoral-Bashing Impulse," in Re-Visions of Shakespeare: Essays in Honor of Robert Ornstein, ed. Evelyn Gajowski (Newark: University of Delaware Press, 2004), 189-214, esp. 210.

33. Juliet Dusinberre, arguably, puts the point about Rosalind most strongly: "She becomes, more than any other heroine, the author of her own drama." "As Who Liked It?," Shakespeare Survey 46 (1993): 9-22, esp. 9.

34. See, for a few examples, Louis Adrian Montrose, "The Place of a Brother" in As You Like It: Social Process and Comic Form," in William Shakespeare's As You Like It, 81-112, esp. 110; Peter Erickson, "Sexual Politics and Social Structure in As You Like It," in William Shakespeare's As You Like It, 113-31, esp. 119; and Claire R. Kinney, "Feigning Female Faining: Spenser, Lodge, Shakespeare, and Rosalind," Modern Philology 95, no. 3 (1998): 291-315, esp. 312.

35. For an account that argues that Rosalind, in giving herself away, does more than mark "the marginal position of the female subject in patriarchal discourse," see Susanne L. Wofford, “To You I Give Myself, For I Am Yours': Erotic Performance and Theatrical Performatives in As You Like It," in Shakespeare Reread: the Texts in New Contexts, ed. Russ McDonald (Ithaca: Cornell University Press, 1994), 147-69. For one of several examples of the complexity of the epilogue's relationship to gender relations, see Phyllis Rackin, "Androgyny, Mimesis, and the Marriage of the Boy Heroine on the English Renaissance Stage,” PMLA 102, no. 1 (1987): 29-41, esp. 37.

36. Harold Jenkins, “'As You Like It,” Shakespeare Survey 8 (1955): 40-51, esp. 50.

37. Jon Erickson, "Defining Political performance with Foucault and Habermas: Strategic and Communicative Action," in Theatricality, ed. Tracy C. Davis and Thomas Postlewait (Cambridge: Cambridge University Press, 2003): 156-85, esp. 167.

38. For accounts that find mutuality in the play, see Kent Talbot van den Berg, "Theatrical Fiction and the Reality of Love in As You Like It," PMLA 90, no. 5 (1975): 885-93, esp. 892; Marianne Novy, Love's Argument: Gender Relations in Shakespeare (Chapel Hill: University of North Carolina Press, 1984), esp. 32; and Nathaniel Strout, "As You Like It, Rosalynde, and Mutuality," Studies in English Literature 41, no. 2 (2001): 277-95. For a more guarded account of mutuality in the play, see Jean Howard, who argues that dissembling allows for "marking a space for mutuality within relations of dominance." Howard, 
"Crossdressing, the Theatre, and Gender Struggle in Early Modern England," Shakespeare Quarterly 39, no. 4 (1988): 418-40, esp. 434.

39. Goffman goes so far as to write that healthy marriages, given the large "number of acting parts which fall within the domain of the role," will always involve a certain element of dissembling. "[I]n well-adjusted marriages," he writes, "we expect that each partner may keep from the other secrets ... With such strategically located points of reticence, it is possible to maintain a desirable status quo" (The Presentation of Self in Everyday Life, 64). 


\title{
8 Hospitable Times with Shakespeare A Reading of King Lear
}

\author{
Thomas J. Moretti
}

Playing is an ornament to the Citty, which strangers of all Nations, repairing hither, report of in their Countries, beholding them here with some admiration: for what variety of entertainment can there be in any Citty of Christendome, more then in London? But some will say, this dish might be very well spared out of the banquet: to him I answer, Diogenes, that used too feed on rootes, cannot relish a March-pane. -Thomas Heywood, Apology for Actors (1612), sig. F3r

Let me not stay a jot for dinner. -King Lear, 1.4.8

Lett all your restes be hopes of happynes, Which mercye's musicke in the soule requires. -Nicholas Breton, Countess Pembroke's Love (1592), $\mathrm{cvi}^{2}$

Whether playing was an ornament to behold or a confection to savor, that theater welcomed strangers is Thomas Heywood's point. A critic or cynic might counter that theatergoers had to pay for entry, that when inside they had to pay for apples, nuts, and ale, that true hospitality in the theater was necessarily lacking. ${ }^{3}$ Perhaps playgoing entailed a kind of "paying hospitality." It costs money for the privilege of being a theatergoer, as if the price of admission at the theater was akin to an ideal hospitable exchange-a guest's initial gift at the threshold. But upon entering the theater, there were no gifts, no dinner, no bed, no refuge (cue cutpurses), hardly manageable lighting, damp drafts, and, at least at the Globe, poor shelter. ${ }^{4}$ The only way for theater companies to offer hospitality was to help theatergoers to pass the time.

Temporality is a key ingredient of hospitality in each of its conventional settings. The risks and promises of what I call "hospitable times" first surface at the threshold, where waiting on the guest comes after waiting for the guest, who, as it happens, must wait to become the guest. To avoid any delay, the passing of time-not necessarily chronologically, but always affectivelyshould be as accommodating, as pleasant, and as fulfilling as the roast and the wine. Once in the manor or the hall, hospitality obtains to the extent that the timing is right. No old gossip or repeated verses are allowed. ${ }^{5}$ No one should wait too long, and no one should linger. 
Hospitality, no matter its location, is always bound up with the phenomenological conditions of time. What distinguishes theater as a distinct site for hospitality is the extent to which theater manipulates timing and temporality-the subjective experience of time-for the sake of pastime. Elsewhere, perhaps coating the palate and filling the belly with the dietary prescriptions for humoral balance can make up for poor timing-the late start, the anxious conversations, the awkward silences, delayed arrivals, hasty departures. Despite the slippages between hospitality and hostility, guests and hosts alike can hope to relax and socialize after a satisfying meal (or jest during a bland one). In the theater, the drive to satisfy guests and hosts, theatergoers and players alike, can only succeed when it shapes time and temporality for the sake of theater people, when labor or currency is exchanged for a form of entertainment that gets the timing right for players and playgoers.

"Hospitable times" includes a range of theatrical offerings, some generic, others less so. Narrative delays increase suspense and thus pleasure; a series of sudden acts or witty repartees can equally satisfy a desire for comedy. Effectively situated soliloquys of mourning, like Hieronimo's or Hamlet's, can recalibrate dramatic pace for the purpose of reflection; sudden entrances or suspenseful scenes can give way to dramatic pauses that can accommodate revelation, disturbing ("Tomorrow, and tomorrow, and tomorrow" [Macbeth, 5.5.19]), or profound ("I wasted time, and now doth time waste me" [Richard II, 5.5.49]). ${ }^{6}$ But stretching out torture scenes, rushing through musings and lamentations, or pausing too long in the midst of banter disrupts expectations of pace and thereby unsettles theatergoers. To mismanage timing and temporality is to make for an unwelcoming and unpleasant time for people in the theater. Bad timing on stage can lead to impatience, boredom, and vexation among the audience and on the stage.

Both King Lear and King Lear are especially attuned to hospitable times: "Let me not stay a jot for dinner," growls Lear. It is not just food that he insists on but its timely appearance, too. ${ }^{7}$ What delays him at Goneril's home (as well as everywhere else) affects his humoral balance more than would an overcooked capon. ${ }^{8}$ It does not matter what the dinner is, so long as Lear does not have to wait for it. King Lear fantasizes a life as a perennial guest whose reception must be instantaneous. ${ }^{9}$ As it might be for a theatergoer, for Lear it is the timeliness of hospitality that counts.

But Lear never gets his dinner, and it seems we wait for a long time to go home to ours. Theatergoers worry as Lear rushes to judgment, and they must endure, if not agonize through Lear's delays before and after the storm. Indeed, he and others hasten or are hastened, delay or are delayed, not just in their comings and goings, receptions and deprivations, but in their emotive, affective responses. What does King Lear tell us about hospitality in the theater, then, once its plot and pace become increasingly inhospitable to theatergoers, once delays in the drama seem analogous to the delays that tax Lear's patience, and once decelerating action forces audience members 


\section{6}

to dwell upon excruciating moments of madness, cruelty, loss, and grief? ${ }^{10}$ What do we make of a tragedy that has auditors, like readers, pause over its most inhospitable moments?

This often unfulfilled desire to make time hospitable even during moments of suffering is integral to this play. Shakespeare adjusts tempo in King Lear to gratify theater guests no less than to pain them. At one moment, he accelerates dramatic action and poetic pace to heighten theatrical effect and to delight audiences with suspense, political treachery, and the promise of reconciliation; just as suddenly, he slows tempo to make the theater (in)hospitable enough for insight, depth, and awareness. What makes the world unaccommodating to Lear, and what makes the play inhospitable to us, are the hastenings and delays that theater might otherwise deploy to make the world bearable and the play recreational.

Hospitable times or affective temporalities in King Lear are fraught with the same sort of contradictions found in hospitality more generally. The benefits and concomitant vulnerabilities of hosts and guests (hospitēs) as Jacques Derrida puts it, the "antinomy" and "aporia" of "hospitality, hostility, hostpitality"-go beyond physical protection and sustenance. ${ }^{11}$ Hospitable acts determine the perception of time and duration, what with expectations of recreation and relief, of music, readings, performances, and conversations that hasten guests and hosts first to midnight, then to bed. ${ }^{12}$ Entertainment and companionship offer hospitēs timely respites from discomfort, anxiety, isolation, and tedium, which are as imminent as rejection, abandonment, and hostility. Time, whether wasted, dragged, passed, or occupied, is crucial to hospitality and is intrinsically affecting.

To disentangle hospitality and time, Derrida directs our attention to Oedipus at Colonus. Hospitality is exigent when, at death's door, Oedipus has his foreigner "host" Theseus take an oath never to reveal the tomb except when, dying, Theseus himself must pass the secret to a trustworthy, honest man. The host (as well as Oedipus's daughters and future confidantes) is taken "hostage" by a dead man's command for secrecy and tempered silence. For Derrida, this "scene of final hospitality" emphasizes how " $[t]$ he guest becomes host to the host" and how everyone is made into everyone else's hostage. ${ }^{13}$ Affective temporalities- "delay" and "haste"- enable these disruptions of hospitality. As soon as Theseus cannot satisfy Antigone and Ismene's desire for grief and closure, the daughters at once receive no time to mourn and experience "an interminable mourning." 14 The sisters cannot mourn because they are never able to see their father's tomb; there is no time for grief because there is no place for grief. Simultaneously, Oedipus has given them a mourning without end, "a limitless respite, a sort of infinite time," a parting gift "more generous and poisoned" than any other and made possible by Theseus's hospitality. ${ }^{15}$ Even as mourning is interminably delayed, it is reallocated, redirected, and intensified by the desire to hasten through grief. Antigone wants, but fails to "hasten back" to her father's tomb, making "the theme of delay [...] insistent throughout this scene."16 Oedipus 
cannot delay death and so "dies without too much delay," but mourning is continually delayed. Like Oedipus, one must be on time, and like Oedipus, and Antigone, and Ismene, one is always late "in some way." Derrida sees this binary tension, this "contretemps," as a managing condition of hospitality. In Oedipus at Colonus, what matters is not that time passes, but that time is felt to pass or not to pass, a cause for what Derrida terms "the incalculable timing of hospitality." 17

Henri Bergson clarifies the ways that hospitess rely upon shared temporalities to receive the benefits of hospitality. ${ }^{18}$ Challenging objective, historical, chronological time, Bergson calls it a construct that we equate with and mistake for space. This, in turn, is to undermine the measurable temporality that underwrites historicist criticism. When Bergson prioritizes phenomenological or subjective time, he challenges the primacy of linear time in the liberal arts, and he locates the imagined cultural landscapes that are the backdrops of much literary scholarship within a supplementary or ancillary time, an emplotted chronology. ${ }^{19}$ Perhaps the only practical response to this Bergsonian challenge is to examine early modern English literature as David Wood has, by both historicizing and theorizing, in his case, the affective temporalities of early modern England in a concerted effort to consider anew that question of St. Augustine- "What, then, is time?"20

Time as "pure" or "true duration," Bergson contends, is more music than history: incalculable, experienced, instant, affecting. ${ }^{21}$ Rather than isolate and evaluate each musical note or movement, the listener immediately blends the music into a rhythmic whole, quarter notes into the rests, the silences. Likewise, we get closer to an awareness of time when we are conscious of our varying somatic reactions as a durable and collected, as opposed to countable, moment. Bergsonian phenomenology thus suggests a sort of cognitive dissonance that transposes chronology for affect. So, although attention to the "quality" of time is possible "in the waking state," it is more readily available in sleep. "[W] hen we dream" he notes, "we no longer measure duration, but we feel it; from quantity it returns to the state of quality." 22

Inversely, the quality of time in King Lear retreats to make space for a less meaningful quantification when one wakes to and consequently is delimited by a chronological, less hospitable world. "Louder the music there," the doctor orders, and Lear is slow to shake off his madness and move from an eternal "wheel of fire" to a life "[f] $]$ ourscore and upward, not an hour more nor less" $(4.7 .25,47,61)$, a curiously inexact measurement of time made out to be exact. His dream of some hell or purgatory and his ekphrastic disclosure of that dream connote the quality of Lear's sleep better than his age, which he fails to calculate accurately, but which seems not to matter here. The doctor warns Cordelia that "it is danger / To make him even o'er the time he has lost" (4.7.79-80)—that is, to historicize him, to set the moments of his sleep and dream to the pace of chronology-because Lear is not ready to reimmerse himself in objective time. Once Lear is ready, then the music can 
stop. This is the wrong prognosis. The real danger, as Cordelia has already presumed, is the damning quality of Lear's time: "O you kind gods! Cure this great breach in his abused nature; / Th'untuned and jarring senses, $\mathrm{O}$, wind up / Of this child-changed father" (4.7.14-17a). What is needed is an instrumental retuning, a return to harmony, a phenomenological adjustment. "Will't please your highness walk?" Cordelia asks her remorseful father (4.7.82b), as if she hopes that their pace, regular but unmeasured-a walk, not a crawl-will somehow recalibrate a somatic, tonal clock in him, with him. ${ }^{23}$

Bergson helps to decipher how the duration of Lear's time supplants calculable time in this scene and in this play more generally. ${ }^{24}$ And when we set Derrida's emphasis on "haste" and "delay" within the context of Bergson's definitions, we learn that affective temporality subtends any promise of hospitality. ${ }^{25}$ Again in Oedipus at Colonus, Antigone and Ismene's suffering occurs not simply because Oedipus has died, and not simply because his death is nonlocalized, displaced, and hidden, but because Oedipus has prevented his daughters from requalifying their temporal experiences. Their inability to mourn completely and to endure happily-Antigone's fatalism is shaped at the moment of Theseus's refusal-deepens Sophocles's tragedy, for it constricts the human capacity to make time hospitable.

Shakespeare tests this capacity when the disguised Kent is forced into the stocks. Gloucester offers to "entreat" on Kent's behalf, but the prisoner would rather try to make his time in the stocks more hospitable, bearable:

Pray do not, sir, I have watched and traveled hard.

Some time I shall sleep out, the rest I'll whistle.

A good man's fortune may grow out at heels.

Give you good morrow.

Kent details his need for hospitality, imagines his position as suitable for rest and recreation, jests, then wishes Gloucester well. It is as if Kent can host and entertain himself while his arms and feet hang in the stocks. Gloucester is unable to play the host at his own home; his other guests, Regan and Cornwall, deprive him of that role long before they "ruffle" his "hospitable favours" with a pluck of the beard (3.7.39-41). Kent accepts the role for himself. He signals what little of hospitality is left in this play: typically dyadic, hospitality is now only a self-directed activity. Whether through sheer force of hopefulness or through a fantasy of self-sufficiency, he claims power over hospitality and time within his otherwise "shameful lodging” (2.2.170).

When Lear first discovers his waking, trapped servant, he recalls Kent's fantasy only to ridicule it: "Ha? Mak'st thou this shame thy pastime?" (2.2.197). ${ }^{26}$ In Kent's attempt to make "shame" a "pastime"- a way to pass the time-the success of his self-referential hospitality in the stocks 
is momentary, and it is exceptional. Attentive theatergoers too might question their own reactions to the play's disappointments and anxieties. Why stay to witness this drama as it unfolds, even to this point, or why try to distract oneself from a shameful play as it moves along impeded, deterred, decelerated, but not ended? Consider the Fool's warning to theatergoers once Lear's delayed transport finally arrives in act 1, scene 5: "She that's a maid now, and laughs at my departure, / Shall not be a maid long, unless things be cut shorter" (1.5.49-50). A play is like the "thing" that, as Julia Lupton reminds us, Heidegger calls "the gathering to deliberate on a matter under discussion." ${ }^{27}$ This play's scenes are its gatherings which, if left to last, will violate those laughing now. Cutting short this play and its scenes, then, might lessen the shame and suffering to follow, but to do so would enervate (or, to extend the Fool's trope, emasculate) the script.

Consider the shared reluctance among many contemporary directors and producers to cut Lear's mock trial in the hovel (3.6). ${ }^{28}$ Shakespeare possibly excised the trial during revisions that led to the Folio version, and Roger Warren attests that the cut improves the play. But the mock trial is typically staged in modern performances; it serves to entertain theatergoers with mad Lear's fantasy that he remains kingly enough to convict his daughters. Warren claims that cutting the mock trial could sharpen the audience's focus on Lear and injustice, but as a result, theatergoers must witness the pain and suffering present in what remains of this scene. ${ }^{29}$ The Folio cuts perhaps signal "Shakespeare's creatively retrospective revision," but not necessarily for "the poetic and dramatic progression of King Lear" that Hans Walter Gabler claims. ${ }^{30}$ Rather, the sharpened focus on Lear's inhospitable times in the Folio taxes theatergoers with little distraction.

In a mostly Folio King Lear, delays in gratification and pauses over suffering are obstacles in the pursuit of satisfaction or entertainment. Contrarily, sleep to keep time and fill the rest with whistles, then the theater, the empty dining hall, the stocks, maybe even a hovel can be hospitable. At least, this is as far as Kent extends his fantasy of self-led hospitality, but it becomes untenable long before Lear takes shelter from the storm and Edgar guides Gloucester to Dover.

This tragedy's characters, like theatergoers and perhaps readers, ultimately prove unable to manipulate affective temporality for a self-serving and self-bestowed hospitality, but the play offers an alternative, an equally fantastic and ultimately tragic means toward hospitable times: to serve others. In act 1 , scene 4, as Lear waits and waits for dinner, Kent tries to change the duration of time for him. Disguised and returned from banishment, Kent replays a scene of hospitality that Lear almost reenacts: the king welcomes an unnamed stranger who requests to serve the king, who seeks the fruits of hospitality by taking on its labors in deference to Lear's "authority" (1.4.9-40). To consummate this hospitable relationship, Lear calls for "[d]inner, ho dinner!" (1.4.42), but it does not come, and once Oswald ignores Lear's demands, delay now signals that Lear "is not entertained with 
[the] ceremonious affection as [he was] wont" (1.4.56-57). To regain control over Lear's time at this crucial moment of temporal loss, Kent beats Oswald. "I thank thee, fellow," Lear tells Kent. "Thou serv'st me and I'll love thee" (1.4.86-87).

Oswald is punished for his own inhospitality and is victimized by Kent and Lear's hospitable bond. In perhaps an act of immediate, reactive retribution, he delays the payoff of Kent's service when he stays for more abuse, which I suspect diminishes any potential comic relief for theatergoers.

KENT. Come sir, arise, away, I'll teach you differences. Away, away; if you will measure your lubber's length again, tarry; But away, go to, have you wisdom? So! [Pushes him out.]

Kent commands "away" four times apparently because Oswald just lies, sits, or stands there, whether in shock or defiance. He tarries until Kent gruffly but graciously pushes him off-stage, with a "So!" like "sol" in the early modern English hexachord, a welcome note after too many pauses, punctuation marks, and repetitions. ${ }^{31}$ In act 2, scene 2, Kent further avenges Lear by refusing Oswald's request for a timely hospitality:

OSWALD: Good morning to thee, friend. Art of this house?

KENT: Ay.

OSWALD: Where may I set my horses?

KENT: In the mire.

OSWALD: Prithee, if thou lov'st me, tell me.

KENT: I love thee not.

Before Kent's slew of barbs against this "knave," "rascal," and "eater of broken meats" comes delay, horses in the mire (14). Kent's inhospitality here, like Oswald's inhospitality toward Lear in act 1, scene 4, is temporal in kind. Oswald hastens from Lear before answering Lear's demand for dinner, and he tarries on stage until Kent pushes him (and so, the play) to move forward. In act 2, scene 2, Kent stays Oswald with such verbal and violent acuity that Kent ends up held in the stocks.

A victim of Lear's initial torrent of inhospitality and a servant to Lear's needs for "ceremonial affection," Kent is keenly aware of the intricacies of time and hospitality. He exercises a fleeting ability to change Lear's time for the better until the storm. Once Lear hesitates to enter the hovel, Kent's fantasies of hospitality-self-reliance and service-effect little. Lear grows mad, despite Kent's help and Lear's own head-bashing and raving. "Lie here and rest awhile," Kent urges, and Lear finally listens (3.6.79), but he is still out of his wits by the time he reaches Dover. When Lear grieves over a dead Cordelia, Kent finally reveals his identity, as if such an act could 
provide one final service to Lear, could distract from or defer the horror of the moment (5.3.276-290). Kent's service, and the failures of that service, are temporal.

Beyond Kent, delay underlies the theatricality and the (in)hospitality of each of Lear's scenes. Cordelia halts the pace of Lear's love game; Lear must cope with Goneril's accusations and subsequent inhospitality; Lear must ask repeatedly who put Kent in the stocks; Lear stays too long in the storm, then outside the hovel, then in the hovel; and he interrupts not only Gloucester's retreat from despair after an imaginary fall, but also, potentially, Edgar's reveal to his father. Excepting Cordelia's actions in act 1, scene 1, these delays do not have a clear narrative function; rather, they operate against conventional paces of plot and even character development. A prime example, the end of act 1 , scene 4, seems to come once Lear curses Goneril- "Create her child of spleen" (1.4.274)—commands his Fool and himself "Away, away!" then exits. Goneril chastises Albany to "[n]ever afflict yourself to know more of" Lear's rage in a curt speech that suggests a conventional end to the scene: "But let his disposition have that scope / As dotage gives it" (283-285). The gathering could end here, but Lear storms back on stage to complain about losing "fifty of my followers at a clap," to eviscerate his oldest daughter with more curses, and to provoke sororal jealousy as a means toward future accommodation ("I have another daughter, / Who I am sure is kind and comfortable") before leaving again (286-302). There is little new to learn here: Goneril has already instructed Lear "[a] little to disquantity your train" (1.4.240); Lear has already chastised her in response (251-253); Lear has already observed that "[y]et have I a daughter left" (247). The scene sputters along: Goneril calls for Oswald twice in the span of fifteen lines and passes the time venting to a nonplussed Albany; the Fool, whom Goneril commands to follow Lear out, calls for Lear to "tarry, and take the fool with thee," (because again, as with Oswald, leaving is wiser than tarrying in this play) (308); and even after Oswald arrives and rushes out to serve Goneril, she readies herself to chide her husband until his interruption finally ends the scene: "Well, well, th'event" (344). Perhaps Albany has in mind some resolution to the conflict, but the "event" that he readies to enter with his exit is another delay. After not getting dinner at Goneril's house, Lear must ask, then holler for his horses at Gloucester's $(1.5 .31,46)$. Lear's pace, and so the play's, is a crawl.

As Lear waits, the Fool offers little respite for Lear and theatergoers. He mocks Lear, but the jests contribute to Lear's growing stress:

FOOL: If a man's brains were in's heels, were't not in danger of kibes?

LEAR: Ay, boy.

FOOL: Then I prithee be merry; thy wit shall not go slipshod.

LEAR: Ha, ha, ha. 
Physical risks from exposure to the cold, kibes, or chilblains make it excruciating to walk; limping or crawling would have to result. As tropes, kibes on the brain signal the temporal limping and crawling that Lear desired in act 1 , scene 1 and that the play has taken as its phenomenological modus operandi. Kibes, the painful outcomes of inhospitality, are best avoided with warmth and shelter; likewise, an ailing mind, the risk of a cold social encounter or an unwelcome moment, is best remedied through a self-willed merriment. Lear laughs instead, but he fails to keep his wits. For Lear, merriment is given by another, but the Fool refuses to give it. Instead, he reminds Lear that sustenance and satisfaction are not possible from his crabapple-daughter, Regan; he answers his own riddles to dwell on Lear's blind hopes in his daughters' hospitality-when he answers them, that is ("Canst tell how an oyster makes his shell?" "Nor I neither" [1.5.25-27]). His jests are either dull ("The reason why the seven stars are no more than seven is a pretty reason" is "[b]ecause they are not eight," as Lear surmises [1.5.33-35]) or raw ("I can tell why a snail has a house [...] to put's head in, not to give it away to his daughters and leave his horns without a case" [1.5.29-30]). Like Kent, the Fool serves time to Lear. Unlike Kent, the Fool does not cater to Lear while they wait, so Lear increasingly obsesses over his daughters' ingratitude and his own vaguely acknowledged sins ("I did her wrong" [1.5.24]).

Not simply the delays of transport, but the Fool's poor service feed Lear's own mental delays and humoral instabilities, best expressed just before the horses are finally readied off-stage: "O let me not be mad, not mad, sweet heaven! I would not be mad. Keep me in temper, I would not be mad" (1.5.43-45). ${ }^{32}$ What cues theatergoers into Lear's descent is not his repeated failure to find his daughters welcoming, nor even the "foul" storm (3.2.24), but rather his reactions to delays and his urge for either haste or patience. If it were possible to run through the play, to rush through moments of exposure, interiority, and suffering, a thrilling, hospitable tragedy would result, with Lear eventually ever on the move. He would progress like the Macbeth that Howard Marchitello gives us, the ambitious man whose political rise parallels his maniacal pursuit of conflated chronological time, in which past, present, and future condense into one sphere over which he has influence, in which actions take less and less time to perform until they take no time at all. ${ }^{33}$ Macbeth (and Macbeth) experiences and tries to manipulate quantitative time through sheer speed of will. But to tarry is to dwell on Lear's troubles here, to prime viewers who will sit through the weightier anguish of the times to come.

Expecting hospitable times, contending with delays, and struggling for patience from the play's onset-despite what Kent provides him, because of what his ruling daughters and his Fool refuse him, and starting with what Cordelia could not or would not exchange with him-Lear grows mad, and his tragedy has inhospitable temporality as its cause. In his first scene, as host he demands to control time in his home-whence Felicity Heal reminds us hospitality ought to spring in the early modern world. ${ }^{34}$ 
Ordering Gloucester to "attend" France and Burgundy, Lear will not wait for Gloucester to return. "Meantime," he will "express" his "darker purpose" (1.1.35) "to shake all cares and business from our age" with "fast intent" so that he can "[u]nburdened crawl toward death" (36-39). From speed to sloth, Lear plans to acquiesce to his experiences of time by relinquishing political command. What matters to him is not when he divvies up the pieces of the realm or even to whom he will abdicate, but rather how long it will seem to take. Yes, Lear believes that what he does now can settle future affairs, that he can decree the future of history: "we have this hour a constant will to publish / Our daughters' several dowers, that future strife / May be prevented now" (43-44). And he is cognizant of how France and Burgundy have "long in our court ... made their amorous sojourn" for Cordelia (47). Nevertheless, Lear ultimately is concerned with what happens in the meantime, in the very moment when one waits for a person to return, a plot line to continue, a conflict to arise, a dinner to be served. The play sets us on a course to take on his preferred temporality, to focus on the meantime as opposed to the plot line or the end of times.

Lear's "fast intent" to split the realm countervails the slow life he plans to lead after relinquishing political command. He will "[u]nburdened crawl toward death" (1.1.39)-his pace will slow to a crawl. To Lear, time is not a system of measurement, an observable phenomenon, so he does not fantasize control over the pace of chronological time. Contrarily, Lear's "fast intent" and "crawl" signal how his actions can shift his perception of time, how hastening and delaying are unburdening processes of duration. The goal is not to hasten abdication and delay death so much as it is to feel like abdication happens instantly and to experience death as delayed.

Lear gains pleasure from such contretemps first in the timing of his plans and soon after in Goneril and Regan's proclamations. With little interest in the substance of their speeches, perhaps he is more attuned to the length and rhythm of the responses, juxtaposed as they are to his curt commands: "Goneril / Our eldest born, speak first"; "What says our second daughter, / Our dearest Regan, wife of Cornwall? Speak" (1.1.53-54, 67-68). For less, his daughters struggle to craft more, in the form of iambic verse, a steady, customary rhythm. Whether prepared or impromptu, Goneril and Regan's speeches mostly manage iambic pentameter $(1.1 .55-61,69-76) .{ }^{35}$ The pattern during the love game is a lopsided exchange of affective temporality between father and daughter. Lear's description of his favorite daughter offers the sort of cadence that Goneril and Regan tried to give him:

But now our joy,

Although our last and least, to whose young love The vines of France and milk of Burgundy

Strive to be interessed, what can you say to draw A third more opulent than your sisters? Speak. 
If the pattern of the exchange has been inversion, a type of sacrifice, less for more, then Cordelia is dutifully curt. "Nothing, my lord" (1.1.87). Lear should have expected as much, or as little, from his more loving words of welcome. When he commands more than a trochaic response from her, she provides three lines of iambic pentameter; when her second attempt proves insufficient, she utters the most impressive verse of the three daughters, but with the most jarring content:

LEAR: How, how, Cordelia? Mend your speech a little,

Lest you may mar your fortunes.

CORDELIA: Good my lord,

You have begot me, bred me, loved me. I

Return those duties back as are right fit,

Obey you, love you and most honour you.

Why have my sisters husbands, if they say

They love you all? Haply when I shall wed,

That lord whose hand must take my plight shall carry

Half my love with him, half my care and duty.

Sure I shall never marry like my sisters

To love my father all.

Ten lines of iambic pentameter-the first line shared with her father, the final three with feminine endings_-and (in the Quarto) a line of iambic trimeter, Cordelia's speech surpasses her sisters' in metrical form. ${ }^{36}$ Perhaps the feminine endings rhythmically confirm what Cordelia's content claims: Goneril and Regan are the same ("carry," "duty"), but Cordelia is distinct ("sisters"); Cordelia seems to err in public, but her sisters inherently err ("sisters"). The point here is that her poetry should have entertained Lear. The irony here is that Lear suddenly cares more about content than form. Cordelia keenly understands the tacit rules of the love game-first to craft a poetically inverse response to her father ("nothing"), then to achieve metrical stability-but in haste Lear changes the rules. From Cordelia, his "joy," Lear expects a poetic performance that contains effusive, "opulent" professions of love. Suddenly, hospitable times are achieved by pace and content.

Cordelia's inability to make time hospitable for Lear during the love game- to offer him a rhythmic oath of love and devotion-and Lear's need for her to help him to pass his time on his terms is at the heart of his rash abandoning of Cordelia, done as it is with the very terms of inhospitality. Consider Cordelia's punishment- to be held from Lear's "paternal care, / Propinquity and property of blood [...] as a stranger to my heart and me" forever (1.1.114-117). She will now lose to "[t]he barbarous Scythian," a stranger who will " $[\mathrm{b}] \mathrm{e}$ as well neighboured, pitied, and relieved, / As thou my sometime daughter" (117-121). "Unfriended, new adopted to our hate, / Dowered with our curse and strangered with our oath" (204-205), Cordelia 
has little recourse-hence, Kent's hope that "[t]he gods to their dear shelter take thee, maid" (183). Her failure to placate her fatherly host leads to estrangement and hostility. It is as if Shakespeare scripts relationships that are contingent upon the proper timing of affecting gestures. France understands as much-Cordelia's act was a "tardiness in nature" (237) — even though her inadequate timing is something France trivializes (he thinks it "most strange" that Lear has disowned Cordelia "in this trice of time" [214-219]).

The hospitable times that Lear expected after abdication but before death-in the meantime-are what Lear desires later with more eloquence and less haste and hate as he heads to prison with his "sometime daughter." Filled with song, gossip, and contemplation, their pastimes together will outlast the lunacy of the world: "we'll wear out / In a walled prison packs and sects of great ones / That ebb and flow by the moon" (5.3.17-19). Always in joy, they will turn captors into captives who "the good years" "devour," "flesh and fell" (24-25). Ersatz prisoners, these perennial hosts will "see 'em starved" before their captors "shall make us weep" $(26,25)$. Lear and Cordelia will freely serve one another, while time will prove abhorrently inhospitable to Cornwall and company.

Of course, Lear will fail to manipulate time in prison, just as he has throughout the play. Haste and delay-the timely affects he desires and expects to control in act 1 , scene 1 -oppress him at each turn. The haste with which he loses fifty retainers- "fifty of my followers at a clap? / Within a fortnight?"-is a quick example (1.4.286-287). The immediacy of the storm on the heath, and his exposure to it, is a more complicated one. His imperative mood_- "Blow," "Rage, blow," "Spit fire, spout rain" $(3.2 .1,14)$ superimposes causality onto the scene to imagine that the elements attend him. His hasty, punctuated diction empowers this fantasy enough so that by the time he decides to seek refuge in the hovel, it can seem as if he has brought the cold upon his own head. He feels momentarily and instantly served by nature- he has demanded immediate service to this point-but his rage obviously neither hastens nor delays the storm, and it fails to protect him against the torrents. Earlier, his hasty acts against his daughters could foster dramatic progression, and thus hospitable times for theatergoers. From this moment forward, he is mad enough to dwell on his pain. As a result, the play makes inhospitable demands on its audience members to stay focused during their experience of delay. When mad Lear is on stage, we follow the action at his decelerating pace. If the playwright and players will not relieve theatergoers from a play that dwells upon the denials and avoidances that result from Lear's shame, and Gloucester's, and Edgar's, then how can theatergoers pass the time? ${ }^{37}$ What does it say about those who remain in their seats or spots as the play plods through Lear's rants?

Before I examine the inhospitable times we have with an unaccommodated and unaccommodating Lear, it is important to set these moments in relief by first noticing how many of the other characters and actions are rushed. To become the Duke of Gloucester himself, Edmund hurries Edgar 
and, through suspicious delay, entices Gloucester to rush to conclusions about Edgar (2.1.21 and 1.2.27-102). Gloucester himself is prone to haste: "Kent banished thus? and France in choler parted? / And the King gone tonight? Prescribed his power, / Confined to exhibition? All this done, / Upon the gad? - Edmund, how now, what news?" (1.2.23-26). The shocking turn of events in act 1 , scene 1 is not enough for Gloucester, who asks for more. In act 5, scene 2, Edgar sits a slowed, blinded Gloucester under a "good host," "the shadow of this tree," but Edgar is so quick to return and to rush his blind father that Gloucester might not know whether to go or come: "Away old man! Give me thy hand. Away!" (5.2.1-2, 5). Gloucester delays when he refuses to leave- "A man may rot even here" under the shade of hospitality-but Edgar already confused the action with his hasty commands. In spite of Gloucester's hesitation, the ensuing panic impresses upon audience members the feeling of a prestissimo tempo that, while sudden and abrupt, is rhythmic enough for dramatic cohesion.

This strategy to hurry along for heightened theatricality is briefly satirized in the fool's parting shot to Lear and to the play as a whole:

LEAR: [...] We'll go to supper i' th' morning.

FOOL: And I'll go to bed at noon.

The rush to prolonged entertainment and satisfaction-supper in the morning, the end in the beginning, death after crawling-is what Lear expected from his generous abdication of the crown and division of the realm. In a rejoinder, the Fool repurposes Lear's call for haste and leaves the play in the midst of things; he intimates that rushed action gives way to short, sudden outcomes; and he reminds us how far Lear has come from his original desire to "crawl." The Fool leaves before Lear slows dramatic pace to the point of stasis. Should we follow the Fool? Do we want the impression of a dramatic pace slowing? Do we want larghissimo, a tempo for introspection, depth, and absorption?

When Lear next appears bedecked in weeds in act 4 , scene 6 , his speeches are disjointed, intriguing, and painfully slow. Although not blind like Gloucester, we are forced to see Lear "feelingly" through the nonsense (145). But stasis arrives with Lear's punctuated repetition. "Fie fie fie! Pah, Pah!" (125). "Now, now, now, now!" (168). "Kill, kill, kill, kill, kill, kill!” (183). "Sa, sa, sa, sa" (199). If his late departures, increasing impatience, and mad digressions delay the play's outcomes-the imminent war, Edmund's plots, Cordelia's arrival—his emphatic monosyllables are far more jarring, unorthodox adjustments in dramatic tempo. A terrible host in act 1, scene 1, he is more unwelcoming to playgoers here. This is not the harmonic music that Stanley Cavell links to King Lear, nor is it the kind of music that Agnus Fletcher imagines when he analogizes dramatic movement with musical progression. ${ }^{38}$ It is not Edmund's villainous harmony— “fa, sol, la, mi” (1.2.137), 
the second part of the hexachord, the C-scale that falters at the last note, the measured, recognizable, conventional pace that backslides once Edgar and Gloucester fall (or when Edmund falls himself). ${ }^{39}$ And it is not like Edgar's delays-his lengthy parley with Edmund, who refuses its continuation (5.3.142-143), or his post-facto reveal to his father off-stage (5.3.180-198). Rather, Lear repurposes the inhospitable times of Cordelia's first reply in act 1 , scene 1 -nothing to dwell on but curt words and abrupt pauses. Lear's madness has him leap headlong into the most unaccommodating of conditions—no food, poor shelter, disturbing forms of entertainment, and abrupt, sometimes incomprehensible mixtures of utterance and pause. With nothing else to hear, and nothing as interesting to see, audience members are forced to bear the delays that spectacular drama, entertainment, and recreation conventionally avoid. Lear repeats elsewhere- "Lear" (1.4.262), "no" (5.3.8), "howl" (5.3.255), "no," "never," and "look there" (5.3.304, 307, 309)—and each time, with varying effect, whether audience members are entertained or not, time is slowed for them. Lear's repetition of words pause us on the present, agonizing moment, and the rests between are hardly the sort that Nicholas Breton hopes bring happiness to the Countess of Pembroke, like music to the soul. ${ }^{40}$

Eleanor Johnson has discovered how the repetition of monosyllabic words became a meditative tool in the medieval monastic world. ${ }^{41}$ The "atomic prayer," best represented in the prose style of the Cloud of Unknowing, approximates God's perception of time. "By praying 'love, love, love,' a practitioner can feel his atomic accord with God's eternity [...] atomic prayer is designed to create a sensible impression of how 'atomic accord' between words, will, time, and, ideally, God's eternal love would feel." 42 Far from any religious purview of King Lear, Cloud nonetheless functions here to signal the power of language over timely affect. Unlike atomic prayer and its resulting accord, Lear's atomic madness so entwines entertainment with inquiry, introspection, and empathy that by play's end, we do not wonder with Kent that Lear (and King Lear) "hath endured so long" (5.3.315), nor do we care about who will rule the kingdom, nor do we dwell on Edgar's last proclamation that the "young / Shall never see so much, nor live so long" (325). We still care about where Lear is looking. We dwell on the last, tragic moment, I contend, because Lear's language so impacts our sense of time that we can hope somehow individually and communally to be held together ("entertained") by the delays that we otherwise find so tortuous and inhospitable in the theater.

Of course, variations in audience, venue, and performance make possible a range of more tolerable versions of King Lear, but there remains a long and well-documented critical history of King Lear as a play too long and too inhospitable for performance-a sign, perhaps, that Shakespeare's King Lear is an experiment in theatrical and poetic timing that sets unforeseen burdens for entertainment on the audience and the readers. ${ }^{43}$ Contemporary performances continue to wrestle with the amount of pain to theatricalize, 
leading critic Charles McNulty to wonder whether the play should be performed at all. "[T]he more I encounter this masterpiece of the theater, the more I'm inclined to go along with [...] Harold Bloom, who [...] concedes: 'Our directors and actors are defeated by this play, and I begin sadly to agree with [English essayist] Charles Lamb that we ought to keep rereading 'King Lear' and avoid its stage travesties." "44 Revisions to craft a more tolerable theater experience seem equally to disappoint. ${ }^{45}$

Perhaps Shakespeare was repurposing and emphasizing the sort of dramatic pace that characters set in earlier plays: Duke Senior delays Orlando's search for food in an attempt at civility and hospitality in the wilderness (As You Like It 2.7.88-118); and, as Daryl Palmer puts it, old Capulet, "the old host" in Romeo and Juliet, "longs to uphold the ancient responsibilities" of hospitality. ${ }^{46}$ But Capulet, hardly intolerable, is closer to Senior than Lear. ${ }^{47}$ To watch or read King Lear is to encounter a version of The Book of Job, not because Lear's and Job's sufferings are always comparable, and not because both texts concern hospitality and inhospitality in the same way. ${ }^{48}$ Job was more hospitable than Lear-Job "opened [his] dores unto him, that went by the way" (31: 32), Lear took "[t]oo little care of ... poor, naked wretches" (3.4.28-34) — but both endure temporal pain. The Book of Job, like King Lear, is framed by the hopes of hospitable times. The narrative moments that bracket Job's much more plodding lamentations also speed to and from those lamentations. Suffering begins and ends quickly, with minimal conversation and no reflection. In the "meantime," the lamentations stretch out suffering with redundant content and syntax. As with Lear and with Gloucester, the textual and performative means of Job's suffering is delay, as it is for readers who tend to Job's long and open complaints to doubting friends. Where Job and Lear truly diverge is at their ends. From Job's troubling and sudden return to grace we move to Lear's shockingly appropriate loss: "Cordelia, Cordelia, stay a little" (5.3.269), a gesture of hospitality that arrives too late.

Between Lear's first "howl" and his death, Kent, Albany, and Edgar prefer a hospitable present for the sake of the future ("O, let him pass," Kent demands [5.3.312]), but it is the inhospitable present that theatergoers find hard to deny. At the convergence of sympathy and longing comes the sort of enduring receptivity only available at the play's most inhospitable entrance, when Lear enters with Cordelia's body. To soothe and suppress the play's increasing distress, critics like Samuel Johnson and Leo Tolstoy might have preferred a Natum Tate revision, a more historically accurate version-a hospitable play. ${ }^{49}$ Those who dare to watch, listen to, even obsess over the memories of Lear's strange, mad, afflicting, and dying words discover the irony of inhospitable times in Shakespeare's theater: "the weight of this sad time we must obey," Edgar declares, but theatergoers are not left with time to obey. The death march sends the dead and living off-stage, where the dead resume their lives out of character and costume. Meanwhile, a conventional jig might begin as a parting pastime before and as guests exit the 
theater, where there is no longer time or place or body to grieve, to mourn, or to dwell upon..$^{50}$ No time to feel, a hardly terminable feeling.

Theater is a unique hosting site in early modern England because it offers timed recreation as its main gesture of hospitality. The achievement or failure of its recreations hinges on timing and attendant experiences of that timing. Jigs, jests, murders, incest, maimings, soliloquies, duels, cross-dressings, barbs, blasts, scents, crowns, cheers, jeers, taunts, blasts, fogs, dogs, and bears are all tools for successful pastime in the theater. King Lear offers some of these, but its persistent challenge to theatergoers is to delay gratification, to settle in with a grief always and already misplaced, and to bring home whatever woe is left over.

\section{Notes}

1. King Lear, ed. R. A. Foakes (London: Arden Shakespeare, 1997).

2. Oxford English Dictionary, s.v. "rest, n.1," accessed February 6, 2015, http://www.oed.com/view/Entry/163890? rskey=Fsc0xR\&result=1\&isAdvanced $=$ false.

3. According to Thomas Platter in 1599, "during the performance [at the Globe] food and drink are carried round the audience, so that for what one cares to pay one may also have refreshment," which evidence suggests was limited to fruit, nuts, water, and ale. See Thomas Platter's Travels in England 1599, trans. Clare Williams (London: Jonathan Cape, 1937); and Andrew Gurr, Playgoing in Shakespeare's London, 3rd ed. (Cambridge: Cambridge University Press, 2004), 43. Sarah Templeman further observes that cracking nuts and chomping apples were "aural irritant[s]" and that "purpose-built playhouses" offered none of the smells and promises of dinner that "inn-yard playhouses” could offer. “'What's This? Mutton?': Food, Bodies, and Inn-Yard Performance Spaces in Early Shakespearean Drama," Shakespeare Bulletin 34, no. 1 (2013): 82.

4. The only records of performance for King Lear before the Restoration point to Whitehall (December 26, 1606) and Yorkshire, but Foakes suggests the play's spectacles are best suited for "an open stage" like the Globe's. "Introduction," King Lear, 5. For more on the 1606 court performance, see Gurr, The Shakespeare Company, 1594-1642 (Cambridge: Cambridge University Press, 2004), 172-73.

5. Consider Jonson's “Epigram CI: Inviting a Friend to Supper," which promises to have a servant read from the likes of Virgil, Tacitus, Livy, "or some better book to us" with "no verses to repeat," as if repetition of lines or words would dull progressive entertainment. Ben Jonson and the Cavalier Poets, ed. Hugh Maclean (New York: Norton, 1974), 12. See Felicity Heal, Hospitality in Early Modern England (Oxford: Clarendon Press, 1990), 104: "feast of the mind [in this poem] is given precedence over the gross feeding of the body, and the quality of the company determines the success of the entertainment."

6. Macbeth, ed. Stephen Orgel (New York: Penguin, 2000); Richard II, ed. Anthony B. Dawson and Paul Yachnin (Oxford: Oxford University Press, 2011).

7. For a reading of this scene in relation to hospitality, see David Goldstein., "Facing King Lear," in Shakespeare and the Power of the Face, ed. James A. Knapp (Surrey: Ashgate, 2015), 82-83. 
8. In Time, Narrative, and Emotion in Early Modern England (Burlington: Ashgate, 2009), David Houston Wood stresses the linkages between time, temperature, and the humors in medieval and early modern thought and art, and he discovers that "the early modern emotions" are "fundamentally and implicitly temporalized, especially as pertains to subjectivity of temporal experience based upon affective states" (31).

9. For Lear's fantasy of "monarch as guest," see Daryl W. Palmer, Hospitable Performances: Dramatic Genre and Cultural Practices in Early Modern England (West Lafayette, IN: Purdue University Press, 1991), 158-59.

10. In Shakespeare, Theatre, and Time (New York: Routledge, 2012), Matthew D. Wagner suggests that theater has it both ways-that "theater places us between phenomenological and objective time," that the "theatre allows for the clock ... to be present and forward in the auditorium, but also to be notably directed by subjective experience" (18). His study helps to address how subjective temporality operates within dramatic narratives that move forward through time. In the end, however, this definition of time in theater confines his readings to that definition. To him, King Lear is a play in which the conflict between a chronological trajectory and subjective temporality is key to the play and to the theater at large, early modern and modern; my argument is confined to King Lear, but it views subjective temporality as the modus operandi for Lear and in the play (86-98).

11. Jacques Derrida and Ann Dufourmantelle, Of Hospitality, trans. Rachel Bowlby (Stanford: Stanford University Press, 2000), 45, 77, 79.

12. According to Nicholas Yonge's Musical Transapina (1588), hospitality does not end with dinner, but includes "madrigals, lute songs," and interesting discussion. Palmer, Hospitable Performances, 16-17.

13. Derrida, Of Hospitality, 123-24.

14. Ibid., 93, 111.

15. Ibid., 93.

16. Ibid., 109.

17. Ibid., 127.

18. Time and Free Will: An Essay on the Immediate Data of Consciousness, trans. F. L. Pogson (1913; Mineola, NY: Dover Publications, 2001).

19. Sarah Lewis provides a brief, current overview of the various scholarship from the mid-twentieth century to today on time in early modern England. "Shakespeare, Time, Theory," Literature Compass 11, no. 4 (2014): 246-57. Her informative overview nonetheless misses key elements in certain contemporary works, including the importance of Edmund Husserl's phenomenology to Wagner's Shakespeare, Theatre, and Time. Like Wagner, Wood gives critical attention to subjective temporality, but in order to examine the ties between the humoral self, affect, and temporality in early modern English literary texts (Time, 1-45).

20. Wood, Time, 36. Jonathan Gil Harris questions our preference for objective time when he unfolds the polychronicities of early modern objects: even though the temporal layerings of material objects still suggests time as chronology, those palimpsest-like objects preclude neat and easy historical contexts. Harris, Untimely Matter in the Time of Shakespeare (Philadelphia: University of Pennsylvania Press, 2008).

21. Bergson, Time and Free Will, 126.

22. Ibid., 126-27.

23. The mystery of walking that interests Peter Stallybrass in the Oedipus trilogy and in King Lear, then, is about phenomenological pace as much as it is about 
human chronology, from toddler to dotard. "The Mystery of Walking," Journal of Medieval and Early Modern Studies 32, no. 3 (2002): 571-80.

24. Of course, King Lear offers various definitions of time: time marks age (1.1.296-300, 4.7.61); it reveals truth (1.1.282-284); it is compartmentalized into eras for the sake of nostalgia and despair $(1.2 .112,4.1 .49)$; it is a measurement of the appropriateness of an action or event (4.6.270-272, 5.1.49); it dictates status (1.2.2-6); it is evaluative (a wound or death can be "untimely," though, with Cornwall's and Oswald's, we know better [3.7.97, 4.6.246]). Likewise, "time" in early modern England was construed as a destroyer and as a providential tool; it could refer to an era or a moment; and it was said to be experienced cognitively (as chronology) and somatically (as affect). See Harris, "Untimely Mediations," Early Modern Culture 6 (2007), accessed February 15, 2015, http://emc.eserver.org/1-6/harris.html; Lewis, "Shakespeare."

25. Articulating the phenomenologies of time in the theater has proven troublesome even when delays in early modern drama have received direct attention. Patricia Parker's astute work on dilation and delay in All's Well As Ends Well and Othello notices how "dilation"- the stretching out of space-could be synonymous with time for early moderns, even though the term never loses its function as a spatial term in her essay and in the early modern texts that she examines. “Dilation and Delay: Renaissance Matrices," Poetics Today 5, no. 3 (1984): 523.

26. While many editors typically place Lear's encounter with Kent in the stocks two scenes later, Foakes makes a convincing case for no scene breaks between Kent's repose, Edgar's soliloquized plan to play Poor Tom, and Lear's discovery of Kent. "Introduction," 238.

27. Thinking with Shakespeare: Essays on Politics and Life (Chicago: University of Chicago Press, 2011), 181, 183.

28. Foakes, "Introduction," 132.

29. For the mock-trial scene as a distraction, see Roger Warren, "The Folio Omission of the Mock Trial: Motives and Consequences," in Division of the Kingdoms: Shakespeare's Two Versions of King Lear, ed. Gary Taylor and Michael Warren (Oxford: Clarendon Press, 1986), 47. Another Quarto scene cut from the Folio, 4.3, could also serve as a distraction for theatergoers who have just witnessed Gloucester's eye-gouging. It has Kent exchange news about Lear and France with a gentleman. Such a scene may lengthen the script, but it might also stimulate ease and relief during and after excruciating moments of theater.

30. Hans Walter Gabler, "Late Twentieth-Century Shakespeares," in The Cambridge Companion to Textual Scholarship, ed. Neil Fraistat and Julia Flanders (Cambridge: Cambridge University Press, 2013), 86. For a review of the ongoing debate over whether authorial revision explains the variances between the Quarto and the Folio versions of King Lear, see Gabler, "Late Twentieth-Century Shakespeares," 79-96; Paul Werstine, "Shakespeare," in Scholarly Editing: A Guide to Research, ed. D. C. Greetham (New York: MLA, 1995), 253-82; and Taylor and Warren, Division.

31. For a brief overview of the renaissance hexachord- "ut, re, mi, fa, sol, la," "usually associated with the six notes, C,D,E,F,G,A or G,A,B,C,D,E" and already being replaced with "the diatonic major/minor octave scale"-see Christopher R. Wilson and Michela Calore, Music in Shakespeare: A Dictionary (London: Bloomsbury Press, 2005, 2014), 453-55.

32. Foakes conflates $Q$ with $F$ here, but each separate version of the line remains repetitious. 
33. "Speed and the Problem of Real Time in Macbeth," Shakespeare Quarterly 64, no. 4 (2013): 425-48.

34. Heal cites the following: Henry Wotton's Elements of Architecture (1624), "Every mans proper Mansion house and home, being the theatre of his Hospitality, the seat of self-fruition, the Comfortablest part of his own life, the Noblest of his sons inheritance, a kind of private princedom" (82; Heal, Hospitality, 6); and Thomas Fuller in The Holy State and the Profane State (1642), "for ones familie, this is of necessity: for strangers, this is Courtesie: for the poore, this is Charity" (153; Heal, Hospitality, 15). These sentiments take root in the Reformation emphasis on St. Ambrose, who "provided a model of giving that could be conceived as a series of concentric circles: the innermost one consisting of the household, since a man's first duty was to his family, and then extending outwards to comprehend spiritual and other kin, neighbours, friends, and finally strangers and enemies" (Heal, Hospitality, 19).

35. Goneril uses alexandrines at lines 1 and 4 . Regan's first line is a hardly effective alexandrine, and her last is iambic trimeter with a feminine ending.

36. Foakes claims that Cordelia's last line was likely omitted from the Folio by mistake (n. 1.1.102-104).

37. For "shame" and "avoidance" in King Lear, see Stanley Cavell, Disowning Knowledge in Seven of Plays of Shakespeare (Cambridge: Cambridge University Press, 2003), 43-79.

38. Cavell calls Shakespeare's drama, specifically King Lear, an accomplishment on par with and attributable to the same kind of tonality that good music offers (later Beethoven, perhaps). Both demand and affect "an experience of continuous presentness," which Cavell suggests is "a continuous attention to what is happening at each here and now, as if everything of significance is happening at this moment, while each thing that happens turns a leaf of time" (Disowning Knowledge, 91-93 and 123). He does not try to connect it to the delays and hastenings that make for the drama's atonal movements. Agnes Fletcher offers a more general connection between poetic drama and music. Fletcher, Time, Space, and Motion in the Age of Shakespeare (Cambridge, MA: Harvard University Press, 2007), 45-46.

39. G. K. Hunter describes Edmund's scale as it "moves across the interval of the augmented fourth, called diabolus in musica (the devil in music)." See Foakes's note to 1.2.137. Perhaps Edmund's is not as atonal as some contemporary strategies, like those which Hollywood composer Michael Giacchino implemented to foretell villainy or misfortune in the television series Lost. Alex Ross, "The Spooky Fill: The Man Behind the Avant-Garde Sounds of 'Lost,'” New Yorker, May 17, 2010, 60-66.

40. I offer a delayed reference to the third quote prefacing this essay.

41. "Feeling Time, Will, and Words: Vernacular Devotion in The Cloud of Unknowing," Journal of Medieval and Early Modern Studies 41, no. 2 (2011): 345-68.

42. Ibid., 355.

43. For a brief review of this history of performance and critical interpretation, see Foakes, "Introduction," 1-2.

44. "With Age, the Wisdom of Staging 'Lear' Becomes Less Clear," Los Angeles Times, August 13, 2014, accessed January 15, 2015, http://www.latimes.com/ entertainment/arts/la-et-cm-king-lear-notebook-20140813-column.html. 
45. Charles Isherwood mocks the 2014 Globe production of King Lear at the Skirball Center for the Performing Arts in New York City for its "disconcertingly festive" use of music and the final jig, which (during the performance that I attended) started after the actors of dead Cordelia and Lear (Bethan Cullinane and Joseph Marcell) slowly rose, stared at each other, and smiled. Isherwood, "Cue the Accordion: A Frolicsome Edge to Old Age and Abject Terror: An Informal 'King Lear' From Shakespeare's Globe,” New York Times, October 1, 2014, accessed November 4, 2014, http://www.nytimes.com/2014/10/02/theater/ the-shakespeare-globes-informal-king-lear-at-the-skirball.html?_r=0. Jocularity ended this production, and humor infused much of it. For a similarly negative review, see Don Aucoin, "A 'Lear' with too much leavening at ArtsEmerson," Boston Globe, October 17, 2014, accessed February 15, 2015, https://www. bostonglobe.com/arts/theater-dance/2014/10/16/lear-with-too-much-leaveningartsemerson/LnZcJdGd3gIgZAxBBQmw2O/story.html.

46. As You Like It, ed. Juliet Dusinberre (London: Arden Shakespeare, 2006); Palmer, Hospitable Performances, 165.

47. Palmer claims that "Capulet's anger" at Tybalt's refusal to welcome the guests whom he hates "looks toward Lear's rage at his daughters, at the failure of hospitable ideals" (Hospitable Performances, 165).

48. Job, in The Geneva Bible: A Facsimile of the 1560 Edition (Peabody, MA: Hendrickson, 2007). For the linkages between Job and Lear, see Hannibal Hamlin, "The Patience of Lear," in Shakespeare and Religion: Early Modern and Postmodern Perspectives, ed. Ken Jackson and Arthur F. Marotti (Notre Dame: University of Notre Dame Press, 2011), 127-60; Steven Marx, Shakespeare and the Bible (Oxford: Oxford University Press, 2000), 59-78; and Julia Reinhard Lupton, "The Wizards of Uz: Shakespeare and the Book of Job," in Jackson and Marotti, Shakespeare and Religion, 174-77.

49. Johnson on Shakespeare, ed.H. R. Woudhuysen (New York: Penguin, 1989), 222; Tolstoy on Shakespeare. Trans. V. Tchertkoff and I. F. M. (New York: Funk \& Wagnalls, 1906), 9-64. Hamlin notes how Shakespeare rejected the historical accounts that have Lear live happily for three more years after the events that Shakespeare traces in his play ("The Patience," 128-29).

50. Whether a jig actually followed early modern performances of King Lear at the Globe is unknown. In Clowning and Authorship in Early Modern Theatre (Cambridge: Cambridge University Press, 2014), Richard Preiss recently inferred that in the 1590s, the Lord Chamberlain's Men pursued a strategy to "disavow the jig, excise it, [...] repudiate it" as a form of entertainment unsuitable to the theater company's established dramaturgic style (156). Even if there were a jig, it might not have been the sort that Will Kemp famously performed. That the Globe Theater Company insists on performing a jig (see note 28 earlier) reveals how jarring an experience it is after witnessing this tragedy's final moments. 
This page intentionally left blank 


\section{Part IV \\ Scripture}


This page intentionally left blank 


\section{9 "Her Father Loved Me, Oft Invited Me"}

\section{Staging Shakespeare's Hidden Hospitality in The Travels of the Three English Brothers}

\section{Sheiba Kian Kaufman}

We are undoubtedly familiar with Manichean paradigms of global history that emphasize oppositional identities, prejudice, enmity, and strife between religions, nations, and cultures. ${ }^{1}$ However, simultaneous with this tumultuous and often pessimistic story of our common past are lesser known narratives, both historical and fictional, that are imagined as collaborative and cooperative in varying degrees. In early modern studies, scholars have addressed these diverse modes of social interactions by examining depictions of both xenophobia and cosmopolitanism in the period. ${ }^{2}$ Leah S. Marcus, for instance, raises the question of early modern attitudes toward religious pluralism and the impossibility of Protestant cosmopolitan coexistence by identifying a Shakespearean thrust toward "insularity": "English provincialism was itself a construction, in no small part a reaction to the shock of separation from Rome and to the establishment of independent networks of connection with other peoples, especially in the New World, the Near East, and Asia." ${ }^{3}$ For Marcus, Shakespeare's plays "acknowledge cosmopolitanism and religious diversity but reject them in favor of an achieved communal harmony." ${ }^{4}$ In her response to Marcus, Julia Reinhard Lupton contends that Shakespeare uses Venice in both The Merchant of Venice (1598) and Othello (1603) as an "experimental setting, a place to test the possibilities of pluralism avant la lettre." Identifying Shakespeare's provincialism or his cosmopolitanism remains elusive because an integral component of peaceful and just coexistence relies upon exercising hospitality toward the stranger: to be a cosmopolite, a world citizen, one must feel at home in unfamiliar domiciles. This universal feeling of solidarity is conditioned through successful acts of embracing a guest, politically and domestically. Yet, such hospitality is often thwarted or hidden in Shakespeare's Venetian plays.

In both Merchant and Othello, potential hospitable encounters take place off-stage or beyond the bounds of the play, leaving only the consequences of the exchange as markers for evaluating the success or failure of hospitality in the play. Shylock begrudgingly attends dinner with his Christian neighbors with little description of the event. The dinner is, nevertheless, a catalyst 
for Jessica's eventual conversion as it gives her the opportunity to flee her home. When Othello defends his amicable relationship with Desdemona and Brabantio before the Duke, he describes a Brabantio we never encounterthe welcoming, hospitable European who opened his door to a stranger, and not the startled, hostile father waking to the infectious alarms of Iago's dehumanizing rhetoric. Following the Duke's invitation to speak in the opening scene before the senate-"Say it, Othello"-Othello begins with a reference to this earlier invitation: "Her father loved me, oft invited me, / Still questioned me the story of my life/From year to year." ${ }^{6}$ Ironically, like the irreverent image of the "beast with two backs" (1.1.116), such a vision of edifying intercultural hospitality is too unseemly to stage or of little dramaturgical interest; nevertheless, the narration of a hospitable golden age not only competes with Iago's dramatized hostility but also signals toward a cultural and literary reserve of cosmopolitan coexistence and interfaith rapprochement that is pivotal for the new worlds Shakespeare engenders.

Moments of hidden hospitality in Othello and Merchant are primers in deciphering the extent of Shakespeare's global visions and the interdependence of such vistas within his society, offering through such narrations a means to measure the range of cosmopolitan impulses in the period. A key text that reveals Shakespearean potentialities of interreligious and intercultural exchange is the 1607 topical travel play The Travels of the Three English Brothers by John Day, George Wilkins, and William Rowley (henceforth Travels). In staging a fictional rendition of the international adventures of the historic Sherley brothers and their attempts to forge an Anglo-Persian alliance with Shah Abbas I of Persia, Travels shares Shakespeare's concern with the limited nature of English hospitality in a time of burgeoning global consciousness. Scholars have written on Travels" "allusive mode" as it calls upon various dramas of the period, including Christopher Marlowe's Tamburlaine and The Jew of Malta. ${ }^{7}$ I would add, however, that a coherent thread underlying the play's intertexuality is the possibility of offering or rescinding hospitality toward strangers found particularly in Shakespeare's two Venetian plays. In analyzing the dynamics of hospitality in early modern drama, I draw upon philosopher Richard Kearney's discussion of what he calls "the anatheist wager"-the foundational moment in Abrahamic religions when the divine stranger manifests as an unheralded guest and the host is faced with a choice to respond with hospitality or hostility - and Bonnie Honig's analysis of foreign-founder scripts alongside early modern and contemporary theories of cosmopolitanism. ${ }^{8}$ Through this double framework, I examine the dramatic portrayal of an improbably hospitable Persia in Travels in dialogue with the seemingly hostile Venetian terrain found in Merchant and Othello. From this perspective, Persia, an Islamic country with a pre-Islamic, biblical, and classical heritage, unexpectedly parallels Venice, a contemporary city known in the period for its pluralism. By reading Shakespeare's narrations of hidden hospitality through corresponding scenes of manifest hospitality between English Christians and Persian Muslims in Travels, a more nuanced vision of early modern religious pluralism emerges. 


\section{Interreligious Hospitality}

From its ancient theological foundations to its modern political configurations, hospitality lies at the heart of human negotiations over rights and citizenship, and thereby offers a dynamic and understudied dimension to "globally oriented scholarship" of the early modern period. ${ }^{9}$ Furthermore, considering the dramatic function of hospitality in light of early modern England's inchoate cosmopolitanism reveals the utility of drama as a framework for burgeoning intercultural and, in particular, interreligious relationships. Theories and practices of intercultural and interreligious hospitality are particularly useful in articulating early modern religious exchanges that call upon, further, challenge, and re-envision Pauline universalism and its claim that " $[t]$ here is neither Jew nor Grecian, there is neither bond nor free, there is neither male nor female; for ye are all one in Christ Jesus" (Galatians $3: 28)^{10}$ in a post-Christian, Islamic temporality-that is, a temporality following the advent and influence of Islam on European society and consciousness. The demanding presence of not only Christian sects but also non-Christian traditions, particularly Islam via the Ottomans, tests Paul's injunctions and its "struggling universalism" and presents the historic drama of how to act harmoniously in the midst of such diversity, if such a relationship is even possible. ${ }^{11}$

Kearney's timely discussion of the imperative for interreligious hospitality in Anatheism: Returning to God After God draws on Émile Benveniste's seminal study of the conflated Indo-European etymology of the word hospitality (hostis and hospes), and provides early modern scholars writing after the religious turn with a discourse to identify early modern religious exchanges that stage the perennial choice facing the host: to respond with hospitality or hostility to the uninvited guest, and to understand the conditions and consequences of that response, historically and ethically. ${ }^{12}$ These foundational moments of anagnorisis, of recognizing and accepting the unknown guest, are "primal dramas of response that serve as portals to faith"; the core scene is found in Judaism, Christianity, and Islam in the narratives of Abraham and the desert visit of the three strangers, Mary and the Annunciation, and Muhammad and the visit of the angel Gabriel. ${ }^{13}$ As Kearney explains, the primary contribution anatheism makes in the wake of the religious turn in theory is essentially hermeneutic and potentially cooperative in its aims and ambitions beyond scholarly discourse. Kearney responds to a range of philosophers and theorists, including Jacques Derrida and his theory of hospitality with its demands of an "unconditional welcome," one that is only perfect and true if it is "absolute" and above the juridical. ${ }^{14}$ Kearney contends that "unconditional hospitality is divine, not human" and therefore a "surplus" rather than an unattainable and thereby disempowering goal. ${ }^{15}$

Hospitality as principle and choice in fiction and in life is, therefore, a state of generosity, curiosity, and humility, and an act that enables the possibility for potential cooperation among diverse cultures. Its dynamism is better captured in hospitability because it is the hospitable environment and 
its accompanying gestures that comfort, nurture, and transform a stranger into a friend. The most successful attempts at hospitality, both secularly and religiously motivated, aim to make the guest feel as if the alien material surroundings he or she temporarily resides in are in fact akin to one's own home- "the stranger that dwelleth with you, shall be as one of yourselves, and thou shalt love him as thyself; for ye were strangers in the land of Egypt" (Leviticus 19:34).

Early modern and contemporary theorists of cosmopolitanism often account for the necessity of hospitality in the endeavor to make humans feel as if they are denizens of an ever-expanding homeland-cosmopolites. Even prior to Immanuel Kant's Perpetual Peace (1795) and its articulation of hospitality as "the right of the stranger not to be treated in a hostile manner," European peace proposals such as Émeric Crucés The New Cyneas (1623), written during the heyday of religious conflict in seventeenth-century Europe, account for a common hospitable core: "we seek a peace, which is not patched up, not for three days, but which is voluntary, equitable, and permanent: a peace which gives to each one what belongs to him, privilege to the citizen, hospitality to the foreigner, and to all indifferently the liberty of travel and trading." ${ }^{16}$ Yet, Crucé, a little-known French monk, repeatedly adds another dimension to this just form of hospitality, namely, an ethical vision of a united humanity:

for how is it possible ... to bring in accord peoples who are so different in wishes and affections, as the Turk and the Persian, the Frenchman and the Spaniard, the Chinese and the Tatar, the Christian and the Jew or the Mohammetan? I say that such hostilities are only political, and cannot take away the connection that is and must be between men. The distance of places, the separation of domiciles does not lessen the relationship of blood. It cannot either take away the similarity of natures, true base of amity and human society. ${ }^{17}$

Crucé's proposal to seventeenth-century potentates is an example of a vision of universal fraternity that combines both the juridical-political views of Kantian hospitality and those ethical concerns Derrida, Kearney, and others later explore. Radically, in outlining his international plan for arbitration, Crucé includes all nations in a general assembly to be housed in Venice, and places the Ottoman Emperor second to the Pope in rank. To borrow Seyla Benhabib's terms, in Crucé we see a "mediation between the ethical and the moral, the moral and the political." 18 Thus, historicizing early modern conceptions of cosmopolitanism and its hospitable foundation opens a window to understanding the various forms of hospitality depicted in the drama of the time. Neither completely about the law nor solely faith based, this multifaceted iteration of hospitality bridges boundaries and creates novel arrangements between seemingly incompatible groups, in Europe and beyond. Like the modern-day use of mediation as a tool of negotiation and 
reconciliation, understanding early modern hospitality as mediated accounts for its complex representation as both principle and right.

Such mediated forms of hospitality are visible in the cultural reservoir the Travels' playwrights invoke when they depict Persia as both antiquated and contemporary. Through this self-consciously hybrid portrayal that merges pre-Islamic and Islamic images and references, we witness a rhetorical return to seminal moments of interreligious hospitality toward the stranger found predominantly in the biblical books of Ezra, Nehemiah, and Esther. In these narratives, hospitality accommodates religious and political alliances between the Persian Empire and the Jews in exile. Consider the story of Esther. The Persian King Ahasuerus (Xerxes) embraces his new wife with great joy and regal "grace and favor" (2:17) without questioning her parentage. However, despite Xerxes' open arms and penchant for his favorite Esther, unbeknownst to him, the Jewish queen faces a formidable enemy to herself and her kindred. Like a Jewish Scheherazade, using her rhetorical gifts to delay her pending execution at the hands of a cruel and jaded ruler, Esther speaks on behalf of the Jewish people and protects them from impending destruction. She asks for a "petition" (5:7) to covertly set up Haman, the counselor promulgating the Jewish genocide, and reveal his perfidy at a banquet. Thus, "Esther's banquet" becomes the very moment when the forces of hostility and corruption in the state are uprooted. More important, her political actions are enabled by the Persian king, thus revealing her sense of ownership and empowerment in this interreligious match.

In this vein, staging Persia initiates a wager for the audience-a wager to remember and accept interreligious interactions that make up a shared biblical consciousness. If "hospitality is a virtue of place" as Brian Treanour describes, ${ }^{19}$ then Persia reigns as a place where hospitable acts occur on stage; it is both particular and universal, defined nominally by an ancient locale and past temporality yet relatively unhindered by cultural markers that render its portrayal "exotic" or "orientalist." 20 The question animating my comparison of Shakespeare's Venetian plays and Travels is what distinguishes hospitality in the latter. What hospitable acts toward strangers are openly explored in this textual reception, sprouting from an earlier Shakespearean germination of the problems of plurality?

\section{"We Give Thee Liberty of Conscience": Facilitating Interreligious Dialogue}

Travels romanticizes the historic Sherley brothers' travels abroad and idealizes their relationship with the Safavid monarch, Shah Abbas I, referred to as the Sophy in the play. ${ }^{21}$ The episodic plot dramatizes the contemporary sojourns of Robert, Anthony, and Thomas Sherley in Persia, Venice, and Constantinople, respectively. When Anthony and Robert arrive in Persia, they are warmly greeted by the Sophy, entertained with mock battles that spur religious debate between the Persians and the English, and accepted 
as ambassador and general by the Sophy in a campaign against the Ottoman Empire. While Anthony the ambassador travels with a dissembling and prejudiced Persian court attendant who has him arrested in a clandestine plot drawing heavily upon Merchant, Robert remains in Persia where his loyalty to the Sophy is tested as he challenges Persian martial traditions to free Thomas from the Great Turk who tortures him on stage. Ultimately, Thomas is freed, Anthony is vindicated, Robert marries the Sophy's Niece, a "pagan," and the play concludes with a hyperbolic exchange of conviviality in a utopian Persian court cast as an ideal realm for experimenting with religious pluralism.

My attempt to define the features of Persian hospitality in Travels rests on identifying complementary attributes characterizing the relationship between Persian hosts and English guests: liberty of conscience and successful political, familial, and religious embraces in the commonwealth. Through this categorization, it becomes clear that Travels represents Persian hospitality as neither unconditional nor conditional but rather as a relationship that mediates juridical and ethical demands between both the host and the guest. In terms of hospitality and hostility, we witness three models: the classic host-guest relationship with its challenges and triumphs through Robert; a mockery of hospitality through Anthony's manipulation by the Persian Cushan Halibeck and Zariph the Jew; and the perils of captivity through Thomas at the court of the Great Turk. The only case of successful interreligious hospitality that takes place in the play occurs in Persia. Here we see Shakespeare's Sophy, mentioned twice in passing in Twelfth Night, take center stage in Travels in an alliance with representatives of Christendom against the Great Turk, who appears as a stereotyped, hostile enemy to both Persians and Christians in the play. ${ }^{22}$

Undeniably and unfortunately, the play's negative portrayal of the Ottomans differentiates the Persian Empire from the Ottoman Empirewhile hospitality may reign as the dominant paradigm on theatrical Persian soil, the play is not exceptional in extending its association of interreligious and intercultural hospitality beyond set parameters. ${ }^{23}$ The same can be said of the negative portrayal of Zariph the Jew, who betrays Anthony and serves as a metatheatrical avatar of Shakespeare's Shylock. The play manipulates the real adventures of the brothers to recreate what Lawrence Publicover identifies as a "playhouse-friendly anti-Turkish narrative" as well as the stage Jew. ${ }^{24}$ There are several reasons why Persia, at this point in English dramatic history, escapes such early modern prejudices, one being that the temporal distance afforded by a combination of biblical and classical narratives sustain its reputation as ancient and distinct from other Muslim nations. In other words, while it is easy and familiar to stage the Turk and the Jew, since there is no parallel "Persia play" akin to the "Turk play," as Jane Grogan notes, the Persian is not an easily depicted type in either medieval or early modern traditions. ${ }^{25}$ 
Travels uses Anthony to magnify the social challenges of hosting Shylock in Merchant. As a reincarnation resurrecting the interreligious tensions within Shakespeare's play, Anthony engages in interreligious dialogue at the court. This step toward interreligious exchange is presented in philosophical digressions on similarities between the Persians and the English following the opening courtly entertainment of mock battles. The congenial tone of the exchange between Anthony and the Sophy contrasts with the bitter banter of Shylock and Antonio's initial dialogue in the opening scenes of Merchant. Antonio's discussion with Shylock over the terms of the bond is riddled with anger, envy, and intolerance on both sides, prompting Antonio to deride Shylock's biblical hermeneutics ("The devil can cite script for his purpose") and Shylock to confront Antonio's bigotry ("You call me misbeliever, cutthroat dog, / And spit upon my Jewish gaberdine"). ${ }^{26}$ Shylock ultimately extends his accusations beyond Antonio to Christians as a single, stereotypical group: "O father Abram, what these Christians are, / Whose own hard dealings teaches them suspect / The thoughts of others!" (1.3.159-161).

Unlike the ongoing struggle to converse across religious lines in Merchant, civil interreligious dialogue is promoted in Travels. After the entertainment of "Persian wars" and "wars as Christians use," mock battles staging beheading in the Persian practice but not in the Christian version, the Sophy, in exaggerated awe of the Christian custom and the introduction of cannons into the Persian army (an historically inaccurate inclusion to bolster the Sherleys' status as military innovators), takes on the wager to accept the brothers in his court as military commanders in his wars against the Ottomans: ${ }^{27}$

Christian or howsoever, courteous thou seemest;

We bid thee welcome in unused phrase.

No gentle stranger greets our continent

But our arms fold him in a soft embrace.

As part of this respectful rhetoric, the play's opening scenes are saturated with repetitions of "welcome" and "stranger" overflowing from the Sophy toward Robert and Anthony, which he further extends to all theatrically transported Christians in the audience: "For thy sake do I love all Christians; / We give thee liberty of conscience" (1.190-191). The Sophy's hospitality stems from his ability to invite the stranger, the uninvited Sherleys, into his court without reservation and with respect to their faith. The play's emphasis on embrace (repeated at the end of the play) presents Persianized hospitality toward English Christians as dynamic - as an active hospitability rather than a static and detached form of toleration. From the Latin verb tolerare, to bear and endure, toleration is not the guiding ethos in the Sophy's court; instead, he enables an embrace, which in early modern usage is defined not only literally as the physical act of friendship but also figuratively through 
a host of accepting actions: worship of a deity, welcoming of friends and services, or joyfully adopting a course of action, doctrine, individual, and more. ${ }^{28}$ The Sophy's offer of "liberty of conscience" presents Persian hospitality and its pact between host and guest as a reverential act that considers the interiority of the guest equally with his physical comfort and needs, thereby joining the materiality of the embrace with the immateriality of the conscience.

The Sophy's liberality is a primary hospitable condition that enables ongoing religious dialogue rather than disagreement and antipathy in the play. When the Sophy asks the central question, "And what's the difference 'twixt us and you?" (1.162), Anthony replies,

None but the greatest, mighty Persian.

All that makes up this earthly edifice

By which we are called men is all alike.

Each may be the other's anatomy;

Our nerves, our arteries, our pipes of life,

The motives of our senses all do move

As of one axletree, our shapes alike ...

We live and die, suffer calamities,

Are underlings to sickness, fire, famine, sword.

We are all punished by the same hand, and rod,

Our sins are all alike; why not our God?

Anthony's description resonates with the universalistic aspects of Shylock's well-known speech in act 3, scene 1 of Merchant: "Hath not a Jew eyes? Hath not a Jew hands, organs, dimensions, senses, affections, passionsfed with the same food, hurt with the same weapons, subject to the same diseases, healed by the same means, warmed and cooled by the same winter and summer as a Christian is?" (3.1.49-53). Both monologues contrast interior and exterior states of faith with physical analogies, yet in contrast to Shylock's pained confrontation with the Christian community in the play, Anthony's speech begins with an emphasis on the "greatest" distinction but then undermines that apparent discrepancy by appealing to the similarity of "each ... other's anatomy." He laments the primary inner value that prompts a distinction in outward practice ("But that's not all: our inward offices/Are most at jar-would they were not, great prince!" [1.174-175]) and concludes with a provocative inquiry to prompt the Sophy's conversion ("why not our God") that is interrupted when a messenger arrives. Anthony's unanswered question hovers over the play as a possibility in Persia, a potential for Christian conversion that never comes to complete fruition. In Travels, the playwrights extrapolate Shakespeare's similarity motif to promote a genuine sense of familiarity that renders English and Persians more unified than distinct. Not only is Persia the setting for interreligious 
discourse and debate, but the entire play is invested in what Grogan identifies as the "vocabulary of likeness" that "produces intriguing moments that break down both boundaries of class and race, if discommodiously." ${ }^{29}$ This sameness or similitude extends to the matter of religion and it is through successful Anglo-Persian hospitality that fictionalized interreligious dialogue can find a nonthreatening arena.

\section{"A League 'Twixt Us and Christendom": Political Embraces}

The idea of religious commensurability between Persians and English Christians, with an emphasis across interconfessional lines to accommodate the historical Sherleys' Catholicism, occupies much of the opening scenes and remains a prominent theme throughout the play. Although the historical Sherleys' numerous international exploits are part of their individual ambitions and schemes for fame and recognition, as biographers of the Sherleys explain, the idea of a Persian-Christian alliance is rooted in a centuries-long relationship between Persia and Europe dating back to humanist historiography and mercantile accounts, if not ultimately to the tale of the Magi in the Bible. ${ }^{30}$ In her study of seventeenth- and eighteenth-century European travelers and their encounters with Zoroastrians, the national religion under the Achaemenid Empire, Nora Kathleen Firby reminds us that

the memory of ancient Persia had never faded completely from the European mind, but after the rise of Islam, Persia was so isolated from the West that little factual knowledge was available in the Middle Ages. Cyrus was known to have freed the Jews from captivity. The tradition that wisdom was derived from the East was reflected in the New Testament story of the three wise men who traveled to the Nativity. The name of Zoroaster persisted as a source of Chaldean astrology and magic, or, more acceptably, as the instructor of Pythagoras and associated with Platonism. ${ }^{31}$

Through references to Persia's ancient heritage and its "renownèd Persian" ruler, ${ }^{32}$ Travels portrays Robert and Anthony as adventurers in an esteemed land and not as English explorers founding an undiscovered country in a New World setting. As in the Esther story, the realm harbors corruption in the court and thus the brothers serve as foreign agents, refounders who prompt change in Persia by identifying the debased constituents. Honig's study of foreign-founder scripts is helpful here in identifying the function and portrayal of refounders in early modern drama: "In the classic texts of Western political culture (both high and low), the curious figure of the foreign-founder recurs with some frequency: established regimes, peoples, or towns that fall prey to corruption are restored or refounded (not corrupted or transcended) by the agency of a foreigner or a stranger." 33 Although focused on conceptions of democracy, both Honig and Benhabib consider 
how the foreigner can alter the landscape of a nation and challenge prevailing traditions and possible prejudices. In this conception of the foreigner's ability to instigate change, Othello and Travels find common ground: both Othello and Robert, with Anthony's aid, attempt to refound their respective settings, domains that are in need of such regeneration because of the social prejudices infiltrating Persia and Venice in their own right.

Distinguished because of its imperial legacy in the case of the former and differentiated for its potential mercantile and cultural experiments in the latter, for both Persia and Venice there is no dramatic discovery of a new world but rather a rediscovery of a state and its pernicious prejudices, embodied in Shakespeare's Iago and his nocturnal calumny against Othello, which creates and unleashes the infectious image of the "old black ram" (Othello, 1.1.87) that corrupts the susceptible white ewes of Europe. In Travels, it is Halibeck and Calimath, a duo of courtiers paralleling Iago and Roderigo in their insidious machinations throughout the play, who personify the reluctance to embrace foreign hands in the wars against the Great Turk.

As the Persian brothers witness the increasing fraternity between the Sophy and the Sherleys, exclamations of their hatred reverberate with Iago and Shylock's rapacious language. Halibeck declares, "Heart, how these honours makes me hate these Christians," and Calimath answers, "Poison finds time to burst, and so shall ours" (2.281-282). Halibeck and Calimath's statements echo Iago's initial protestations against Cassio's promotion (Othello, 1.1.7-32). ${ }^{34}$ While the Sophy quickly assents to Anthony's offer of an Anglo-Persian alliance against the Turks, "a league 'twixt us and Christendom" (3.160), Halibeck and Calimath are truculent toward such a profane union, and Halibeck openly reminds the Sophy of his regal legacy and pre-Islamic heritage:

Shall you, whose empire for these thousand years

Have given their adoration to the sun,

The silver moon and those her countless eyes

That like so many servants wait on her,

Forsake those lights?

Coupled with the Sophy's repeated invocation, "Next Mortus Ali, and those deities / To Whom we Persians pay devotion" (1.87-88; emphasis added), the references to the "sun" "moon" and "lights" refer to pre-Islamic Persian traditions of Mithraism. These European conceptions of ancient Persian religion de-Islamize the nation through its associated paganism, its "natural" religion, and its yoking together of past and present temporalities that register with the early modern understanding of classical and biblical Persia. ${ }^{35}$ The playwrights thus rhetorically shape the Sophy's court through references to ancient Persian solar worship, the long-standing cultural misconception of the Zoroastrian faith of the Achaemenid Empire. This type of 
hybrid religious identification provides a dynamic space within the playwrights' pseudo-ancient Persia wherein strangers can become friends and the possibility of an East-West embrace materializes. This interstitial religious space allows for a theatricality of exchange, a fluidity of identities and hospitable relationships between the Sherley brothers and the inhabitants of their imagined Persian court. ${ }^{36}$

The first two scenes of the play, therefore, cater to a philosophical and spiritual discourse on the nature of an Anglo-Persian alliance and the potential advantages and disadvantages for the Persian court in accepting these foreign agents on behalf of the state. The playwrights further call upon the rhetoric of a Christian crusade, and thereby cast the alliance as one of the Sophy's near conversion. Before the Sophy accepts the proposal he asks, "What profit may this war accrue to us?" and Anthony responds, "Honour to your name, bliss to your soul" (2.187-188). While Halibeck and Anthony debate the superiority of the Persian God and the Christian God, both mirroring each other's dialogue in the repetition of "our God," the Sophy remains an observer who ultimately accepts the wager to unite with "Christendom," granting Robert the "place of general" (2.279) and Anthony the position of "Lord Ambassador" (1.267) who will be sent to Venice to obtain a jewel for the king with Halibeck at his side.

\section{"You Forced My Thought to Love Him”: Familial Embraces}

Like Iago and Roderigo who use their provincialized rhetoric to appeal to prevailing societal prejudices to color Brabantio's view of Othello as a dark beast, Halibeck, in an aside, declares his hostility in deference to his culture and ancestry- "Ye Persian gods, look on: / The Sophy will profane your deities / and make an idol of a fugitive" (1.156-158)-revealing at once an esteem toward Persia's imperial and pre-Islamic past and his encumbering attachments to his exclusive Persian community. Despite Halibeck and Calimath's protestations, the alliance between the Sherleys and the Sophy ensues, and the play subsequently turns to the romance between the Sophy's Niece and Robert, beginning with a scene between the Niece and her maid Dalibra, which is noted for its debts to both the initial dialogue between Portia and Nerissa in Merchant and the discussion between Desdemona and Emilia regarding Othello's jealousy. ${ }^{37}$ Resembling in context but not in tone Emilia's sardonic comment- "they are all but stomachs, and we all but food" (Othello, 3.4.99)—Dalibra playfully inverts the bitterness of Emilia's cannibalistic comparison when the Niece asks her what she thinks about the Sherleys: "if they be as pleasant in taste as they are fair to the eye, they are a dish worth eating" (3.6). When the Sophy's Niece expresses "suspicion" (3.130) toward the Englishmen, her maid chides her, saying, "Strangers? I see no strangeness in them. They speak as well or, rather, better than our own countrymen" (3.22-23). Once the Niece meets Robert, she is caught between her desire for and doubts about a romance with him. Prompting 
aspirations of ancient Persian solar sublimity for Robert, in lines that recall Desdemona's comments about Othello_- "I think the sun where he was born / Drew all such humors from him" (Othello, 3.4.30)-the Sophy's Niece encourages Robert's saturation in the Persian environment: "The glorious sun of Persia shall infuse / His strength of heat into thy generous veins / And make thee like himself" (3.80-82). As Robert leaves, the Niece, in an aside, bemoans the religious difference between them: "fare the well, good Sherley. / Were thy religion ..." (3.107-108).

In "dreaming" (3.118) of the possibility of marriage with Robert, the Sophy's Niece aligns herself with the story of Aeneas and Dido, an intercultural union that was tragically doomed despite Dido's welcome of the Trojan stranger. In conjuring this ill-fated couple, she reflects the anxieties found in these love stories, worrying that Robert, like the "true Trojan" (3.121) will play with her heart; the foreboding allusion also recalls the mythological references to "Cressid," "Thisbe," and "Dido," in the moonlight dialogue between Lorenzo and Jessica in the final act of Merchant, suggesting that there too lurks the possibility of a tumultuous future for the newlyweds. Moreover, when the Sophy's Niece compares Robert to the "wandering knight, Aeneas" (3.120), her nomadic description of the legendary founder echoes Roderigo's pejorative identification of Othello as a "wheeling stranger / of here and everywhere" (Othello, 1.1.135). Despite the shade of suspicion, the Niece's admonition of Persian cultural and religious imbibing works as Robert begins to assume a foreign persona. However, like Othello, Robert's embrace of an alien culture proves perilous to the hostguest relationship because his assimilation assails the ipseity of the host. Although the Sophy emphasizes the priority of Persian laws over the right to hospitality when he establishes the conditions of his hospitality toward Robert from the first mention of genuflection to his demand to maintain Persian martial traditions, as the play continues, his hospitality toward the Sherleys, and Robert in particular, brings to light the potential risks of the hospitable act. Hence, hospitality toward the favorable stranger, Robert, ushers forth various usurpations of the Sophy's personhood and demands the Sophy's response to such an imposition.

At the heart of the Persian martial "custom[s]" (6.25) in the play is the practice of killing prisoners of war, and it is the very malleability of this law that binds the Sherleys, the Sophy, and Persia in an alternative form of mediated hospitality. Despite an early model of mercy in the mock battle opening the play, Robert initially relinquishes the Christian practice in loyalty to the Sophy, thereby proving his status as the law-abiding guest even to the extent of acting as general for the Sophy. When he enters- "Enter Robert and other Persians" (7)-he takes on the Persian ethos in his response toward the prisoners and abides by the laws limiting his rule: "We are now here the Persian substitute/And cannot use our Christian clemency" (7.14-15). Furthermore, in a moment of conflated religious identity, Robert turns to the Turkish prisoners and demands, "Speak, do ye renounce your prophet Mahomet? / Bow to 
the deity that we adore / Or die in the refusal" (7.16-18; emphasis added). Here, the use of the plural first-person pronoun emphasizes Robert's lack of differentiation from the Persian majority and recalls Othello's identification with his Venetian citizenship when he rebukes his drunken soldiers: "Are we turned Turks" (Othello, 2.3.161; emphasis added). While Robert's proclamation leaves open the possibility that the Turk may need to answer in the Christian affirmative, a Persian soldier follows Robert in urging the prisoner to "[j]oin Mortus Ali then with Mahomet" (7.20-23), clarifying the expected answer. Finally, when a Christian in Turk's habit enters as a messenger from his imprisoned brother Thomas in Constantinople, Robert quickly declares the disguised Christian's death- "We'll have no ransom but conversion" (7.26) - suggesting, through syntactical confusion conflated with the Persian soldier's response, that conversion to Christianity or the Persian religion is acceptable.

When Robert challenges the Sophy's identity and customs as he tries to free Thomas from the Great Turk, he reveals how "the guest's hostility is an imminent possibility within the hostis relation, a menacing consequence of his potential interchangeability with the host," which renders the Sophy's realm unheimlich. ${ }^{38}$ The Sophy angrily conveys Robert's heroic transformation in alchemical terms that draw upon the Niece's solar references: "Dares that proud Sherley, whom our powerful heat / Drew from the earth, refined and made up great; / Dares he presume to contradict our will" (6.2-4). In addition to Robert's military transgression, his relationship with the Sophy's Niece is a cause of further antagonism for the Sophy who begins to see Robert as a potential threat to the throne. Like Brabantio in the opening of Othello, the Sophy learns about the possibility of a romance between his Niece and Robert not from either of the lovers, but from the injurious third-party voice, Calimath, which further fuels his growing rancor toward Robert. The outraged Sophy exclaims,

Alter our customs, steal our subjects' bosoms, And like a cunning adder twine himself About our niece's heart! She once his own, He's lord of us and of the Persian crown.

When the Niece is summoned and interrogated, like Desdemona, she boldly asserts her love of Robert—-"That I love him: true" (6.43)—and turns upon the court as a solicitor on behalf of Robert: "If he had his due / You should all love him; he has spent a sea / of English blood to honour Persia" (6.43-45). Initially, however, the Sophy sees this union as one "against all rules of nature" (Othello, 1.3.102) and castigates his Niece:

Forgetful of thy fortunes and high birth, More bestial in thine appetite than beasts. 
The princely lioness disdains to mate

But with a lion; time and experience shows

That eagles scorn to build or bill with crows.

The Sophy's outrage at such a disparate marriage mirrors Brabantio's speech before the Duke- "in spite of nature, / of years, of country, credit, everything"-(Othello,1.3.97-98) and Iago's later affirmation of it: "Not to affect many proposed matches / Of her own clime, complexion, and degree" (Othello, 3.3.233-234). Like Othello's nostalgic report of Brabantio's prior hospitality - "her father loved me, oft invited me" (1.2.128)— the Niece reminds the Sophy of his earlier visible embrace of the Sherley brothers: "You forced my thought to love him, and like a tutor / First taught my tongue to call him honourable" (6.59-60). Thus, while this latter theatrical embrace is staged and then reiterated in Travels, in Othello the hospitable welcome resides beyond the parameters of the play, and thereby marks the beginning of the play as already far removed from harmonious relationships and the potential for unity found therein.

Later in the scene when the Sophy's anger at his unruly guest quickly dissipates once Robert explains his motivations for keeping the prisoners and his lack of ambition for the crown and his Niece, the Sophy tests her devotion to Robert by presenting a "counterfeit head like Sherley's" (stage direction). In response to the prop, the Niece alludes to Antigone's legendary actions: "Let his dissevered head and body meet. / Return them me, let me the credit have / And lay his mangled body in a grave" (6.232-234). After the Sophy reveals his fabrication and eschews his temporary senex stance, he reverses her declaration with a statement that invokes Desdemona's foreboding desire to be shrouded in her unsullied wedding sheets and transforms the tragic sartorial symbol into one of celebration: "And having joined his body to the head / His winding sheet be thy chaste marriage bed" (6.237). ${ }^{39}$ The Sophy's understanding and accommodation of Robert's transgression against Persian military and marriage customs exemplifies the mediated form of hospitality I have been tracing in the play: the Sophy maintains his dignity and right to rule and judge throughout the play, but allows for certain compromises with his guest, depending on his background and worth to the realm. In this sense, laws and customs of the realm are presented as flexible and conciliatory to the guest rather than binding or arbitrary.

\section{"I Am, Like Thee, a Stranger in the City": Religion at the Dinner Table}

As the Shah's ambassador, Anthony travels with Halibeck to meet the Emperor of Russia and the Pope. Anthony's stop in Venice consumes three consecutive scenes at the center of the play and draws heavily upon Merchant..$^{40}$ Anthony, like Antonio, is caught in a monetary exchange with Zariph the Jew who 
desires to "taste a banquet all of Christians' flesh" (9.23). However, while the scene borrows from Merchant, it departs in significant ways, including in its metadramatic portrayal of the stage Jew, Zariph. Anthony, who owes him "gold" for a "jewel" he bought for the Sophy, asks Zariph for "forbearance" and reminds him that he too is a visitor to Venice: "I am, like thee, a stranger in the city. / Strangers to strangers should be pitiful" (9.35-36). Furthermore, while Shylock's accusations toward the Venetian Christians- "villainy you teach me I will execute" (Merchant, 3.1.59-60)—is never acknowledged by the Christians in Merchant, Anthony takes ownership of such hypocrisy. When Zariph contends, "If we be learnt of Christians / Who, like to swine, crush one another's bones" (9.37-38), Anthony answers, "Is it sin in them?" Tis $\sin$ in you" (9.39). Lastly, when Anthony invites Zariph to a banquet, he refuses and meta-dramatically answers: "No banquets; yet I thank you with my heart-[aside] And vow to play the Jew; why, 'tis my part" (9.50-51). ${ }^{41}$

In Merchant, Shylock's attendance at the dinner provides an opportunity for his daughter Jessica to escape his household, pilfer his money and possessions, and ultimately elope with Lorenzo and convert to Christianity. Thus, the off-stage banquet, with the potential of Pauline unity and inclusion, not only eschews any harmonic ends, but also further intensifies Shylock's anger toward the Christians in the play. In approaching the play from the point of view of "culinary exchange" rather than financial negotiations, David Goldstein points out that despite the play's obsession with the language of food, staged eating is absent in Merchant. Goldstein identifies the potential for community building through the "commensal event" of a shared meal and concludes that in Merchant "every opportunity for eating together offers, and then withdraws, the possibility of hospitality." 42 This commensal void seems to have captured the interest of the Travels' playwrights, presumably for rhetorical rather than ethical ends, and thus Shakespeare's elusive banquet is staged with great immediate costs to Anthony because of Halibeck's machinations. Through this staging, the playwrights probe the conditional state of what could happen when such fraught hospitality between Christians and Jews is staged.

In Travels, Anthony is host to the banquet, a dramatic moment that often magnifies the "vulnerability" of the host, leaving him in a "dramatic snare" that leads to his demise as Daryl W. Palmer explains. ${ }^{43}$ Here, Zariph and Halibeck, Jew and Muslim united in hostility, conspire against Anthony, an "uncircumcised slave" (10.10) and have him arrested during the course of the banquet in Venice with its overt biblical allusions to the Last Supper. When Anthony is arrested, his earlier appeals to fraternity and solidarity evaporate, as he calls Zariph an "[i]nhuman dog ... true seed / of that kiss-killing Judas" (11.91-93) who betrays him "in midst of courtesy" (11.91). Rather than the Sophy's embrace, Anthony is caught "in a serpent's arm" (11.112). While Zariph enjoys the theatrical indulgence of his pernicious action, declaring he will relive this scene again- "I shall dream of this happiness tonight” (11.109)-Halibeck acts with greater malignant efficiency. Earlier 


\section{2}

in the scene, he cuts Zariph's indulgences short to describe his Iago-like motivations, stemming from an unadulterated hatred of the foreigner and his exterior status rather than his interior value: "Ere any stranger shall with me walk even, / I'll hate him, were his virtues writ in heaven" (10.56-61).

While Anthony suffers at the hands of this malicious partnership, his brother Thomas is abandoned by his crew and subsequently captured and tortured by the Great Turk until letters from "England's royal king" (12.130) secure his release. His captivity scene is cast as the inverse of the Sophy's hospitable embrace as the Jailor describes the physical terms of his Turkish imprisonment as analogous to the hostile gestures rival Christian groups extend one another in the struggles of the Reformation: "for I am sure ... these five or six month at least he has had nothing but the hard board for his bead, dry bread for his food and miserable water for his drink. And we Turks think that it is too good for these Christians too; for why should we do any better to them, since they do little better to one another?" $(12.10-15)$. As with the favorable depiction of the Pope, and later a hermit counseling Robert on his spiritual duty to maintain his Christian faith in Persia, the play's investment in a united Christendom accommodates multiple purposes beyond commentary on interconfessional challenges of the time. Richard Wilson elucidates the Catholic interests of the play, which were intertwined with attempts by Catholic gentry, including the Sherleys, to gain toleration under James who had made such ecumenical promises before taking the throne. ${ }^{44}$ In using Persia as "a screen for Catholicism" so that Persia and England can unite in a "new Crusade," the play's adventurers, like its Persian setting, register multiple temporalities. ${ }^{45}$ In alluding to medieval romance, the brothers are akin to Christian knights; yet, as contemporary representations of early modern travelers and self-fashioned ambassadors, they are also at the cusp of the burgeoning discourse of trade and cross-cultural exchange.

\section{Forms of Coexistence}

The global aspirations of Travels are not easily reconciled with either its archaic representation of medieval knights-errant or its portrayal of an exclusive form of Anglo-Persian coexistence. As Anthony Parr summarizes, "this ecumenical vision has its human limits in the play-no room in it for Turk or Jew." 46 This limited form of Christian tolerance appears in another European peace proposal contemporary with Crucé's utopian vision of international peace and prosperity: The Grand Design of Maximilien de Béthune, Duke of Sully. Unlike Crucé's Cyneas, which reads like a discursive prototype of the League of Nations, Sully's plan for a "very Christian Republic in a state of enduring internal peace" aims to unite Christian rulers, allow tolerance for Catholics, Lutherans, and Calvinists, and establish an army "for maintaining continual war against the infidels," the Ottoman Turks. ${ }^{47}$ In comparing the rhetoric of both proposals, a continuum of 
tolerance and intolerance emerges with Crucés wide embrace on one side and Sully's limited embrace closer to the other end. In the plays I have been discussing, we see the enactment of these varying punctuations on the continuum through distinct forms of receiving the stranger in the commonwealth. Thus, in Travels when Jew and Turk are expelled from scenes of hyperbolic solidarity between Persians and Englishmen in the play, their separation is both a product of their stage histories as well-known types in the drama of the period and a depiction of limited toleration in the play. Although Robert's Persian welcome and final absorption into the realm is radical and utopian in its own right, the play in its entirety gravitates away from the Crucé end of the spectrum, revealing thereby the tension between utopian politics and Realpolitik.

Although lacking in the overt, exaggerated, and mediated hospitality characterizing Persia and its exclusive form of coexistence between Persians and Christians, the Venice of Merchant and Othello refuses to throw out its guests. Shakespeare does not exile the ethos of the Jew or the Moor in his plays but rather dramatizes the early modern problematic of religious coexistence in the forced conversion of the one and the "death into citizenship" of the other. ${ }^{48}$

In Merchant, Shylock's formal rather than spiritual conversion, although damaging to his person in ways Travels avoids by skirting a conversion of the Sophy's court, assures his physical presence in Venetian society while his will ensures material security for Lorenzo and Jessica, an interreligious marriage based on conversion unlike that of Robert and the Sophy's Niece. Robert as Englishman in Persia may participate in altering or eliding certain laws and customs, but Shylock, a Jew in Venice, is subject to the law and must fulfill his pact as resident "alien" as Portia reminds him in the trial scene: "The law hath yet another hold on you" (4.1.358). The play ends with a textually burdened, detached, juridical solution rather than with an equitable compromise between Antonio and Shylock, ${ }^{49}$ yet it also signals toward a future Christian state that desires to uphold a Jewish presence with all its potential commercial ramifications in a state of conditional hospitality. As Aryeh Botwinick posits, in Merchant "a Judaically softened and modulated Christianity, as the state religion that even a Jew can live with, can serve as the basis for a new vision of civilizational amity and progress." 50 In this imperfect arena of early modern cultural and religious exchange, this same inherent desire for change is found and amplified in Travels and Othello: the Christian Venetian state absorbs Judaism and the Moor as reconverted Muslim just as Persia absorbs and accommodates Christianity through the Sherleys.

While it may seem that through Othello's suicide the Moor and all instances of the stranger, whether pagan or Muslim, are expunged from the play, it is in his final speech that Othello reasserts his Venetian citizenship- "I have done the state some service, and they know't (Othello, 5.2.338)—and reminds the Venetians of their obligation toward him as a naturalized citizen by laws 
established in Cardinal Contarini's The Commonwealth and Government of Venice (1599), which articulates that "foreign men and strangers" could be naturalized "either in regard of their great nobility, or that they had been dutiful towards the state, or else had done unto them some notable service." 51 Moreover, this is Othello's second declaration of his citizenship; he invokes his contributions to the state at crucial moments of potential estrangement from his naturalized home. His first reference to his citizenship is recalled when he finds he must prove himself worthy, perhaps to himself as well as to the magnifico, when his marriage is questioned: "My services which I have done the Signory / Shall out-tongue his complaints" (Othello, 1.2.18-19). Othello is confident that his inner attributes, his "demerits" and "parts" alongside his "title" and "perfect soul" will be enough to fairly "manifest" him as a consort for Desdemona (Othello, 1.2.22, 31, 32). Indeed, as the Duke presents Othello with the impending crisis in Cyprus, ordering him to engage in battle "[a]gainst the general enemy Ottoman" (Othello, 1.3.49-50), the state of emergency trumps Brabantio's resistance to Othello's integration through marriage and the state officiates the union. Because of the state's dependence on him, because "the fortitude of the place is best known" to him, and "opinion, a more sovereign mis / tress of effects, throws a more safer voice on" him (Othello, 1.3.221-224), his citizenship and marriage are not lost.

Othello commits suicide by tragically completing one last service to the state against the "general enemy," and by invoking his right as a Venetian when his citizenship is most dubious, he ensures that his presence as part of the state and its legacy is not erased. On the potential ramifications of Othello's suicide, Lupton argues that on the one hand, "Following the directive of Paul in Romans 2, Othello has indeed circumcised himself in the heart, reentering the Christian covenant through his expiatory death. Moreover, this sacrificial cut also signs and seals Othello's death into citizenship, his entry into the archives of state memory as a citizen-soldier." ${ }^{52}$ However, as Lupton further suggests, the "reinscriptive cut," taken from Judaism, is a "legally ratifying and self-identifying mark that dislodges Othello from the Christian historical order by locating him in a different covenant." ${ }^{53}$ His death as "circumcised" Moor reasserts Othello as Honig's "much-needed" foreign element in the "vulnerable moment" concluding the play. ${ }^{54}$ Othello's reinscription through his reference to the Contarini document and through his suicide transforms him into a sacrificial non-Christian refounder whose alliance with the Venetians purges the state of its most corrupting element, Iago, much like the Sherleys' arrival and service in Persia rids the Persian court of the representative forces of disunity and hostility, Halibeck and Calimath.

When the Great Turk tortures Thomas on the rack on stage in an attempt to make him reveal his identity and then to recant his faith and join the Turks, the steadfast Sherley brother refuses to "turn apostata" (12.114). Thomas's reference to apostata follows another critical invocation of the term; during her interrogation, the Niece reproaches the Sophy for his 
mercurial attitude when he recants his welcome of Robert, claiming, "And is affection turned apostata" (11.63). As in Othello, "turning" in Travels is a problematic term, a phrase reverberating with the early modern fear of "turning Turk" - a moment of Christian "betrayal," "subversion," and ultimately "renunciation both of God and of country." "As Daniel Vitkus explains, the "idea of conversion that terrified and titillated Shakespeare's audience was a fear of the loss of both essence and identity in a world of ontological, ecclesiastical, and politically instability." ${ }^{56}$ Considering the cultural aspersion toward such an act, it is notable that Travels only flirts with the idea of cultural and religious conversion through Robert, "the Persian substitute" and the Sophy's exaggerated embrace of the Christian brothers. In this drama of similitude and exchange, Grogan concludes that "if the play began with an over-emphatic insistence that it is the Persian who will be made to be like Englishmen through the ministrations of the Sherleys, what the play actually depicts is Englishmen acting like Persians: inglese persiani. $" 57$ Ultimately, as in the case of religious dialogue versus conversion, where the aim is to find common ground but not necessarily convert one another, the representative of each faith maintains his or her position, a solution that Shakespeare does not posit in Merchant and Othello. Instead, for Shakespeare, religious hospitality remains conditional, contingent, and elusive, an improbable and imagined social ideal known primarily through its absence and negation.

Like Merchant, Travels concludes with all potential catastrophes diverted; Anthony is cleared of his charges, and both Halibeck and Calimath are punished, the former to death and the latter to oversee his brother's execution. The Sophy promises to grant Robert his free reign in Christianity, an idealized ending that embraces Robert as the law-decreeing host founding his own hospitable domain within Persia for Christian immigrants. Robert will baptize his child with the Sophy himself as godfather, "erect a church / Wherein all Christians that do come / May peaceably hear their own religion," and "raise a house ... where Christian children" will only know "what by Christians is delivered them (13.177-179,187-191). Although detailing aspects of a sequestered domicile with little interreligious interaction, Robert's description of a wider society wherein Christians and Persian Muslims live and maintain their individual identities both revisits and revises the conclusion of Merchant, wherein only a Shylock bereft of his religious identity is tolerable in Venetian society, and emphasizes his camaraderie with the Sophy, of feeling at home in Persia.

While neither the Sophy nor his Niece become Christians in the play, the entertainment of concluding with "[a] show of the Christening" (13; stage direction), with its overt symbolism of the rebirth of Christianity in the East, suggests that the initial interreligious dialogue between Anthony and the Sophy coupled with Robert's Persianized ways, influences the Persian court. Persia is not a Christian country, but it is hospitable to Christians through the combined royal forces of the Sophy and 


\section{Sheiba Kian Kaufman}

his Niece. While Robert claims that through his baptized child "Sherley in Persia did the first Christian make" (13.55), it is the Sophy who orchestrates the christening, claims that his "royal hand / Shall make thy child first Christian in our land" (13.200-201), and appropriates his proper position as sovereign host, subordinating Robert by the end of the play. Yet, the inclusion of a Christian religious rite also recalls the Sophy's opening proclamation of "liberty of conscience" in Persia; the Sophy and his purified court retain their Persian identity and faith, but in a novel arrangement, allowing for coexistence with Christians. His court is not converted or attempting to convert others, unless they are Turkish prisoners, but rather an unusual haven for Christians to live alongside non-Turkish, Persian Muslims. The question Anthony asks the Sophy, "and why not our God," is not overtly answered through scenes of conversions, but rather through acts of hospitability toward Christianity in not only politically promoting Robert and Anthony but also in going beyond tolerance and participating in a Christian ceremony in Robert's newfound home.

In remembering its Shakespearean forbearers' challenges with welcoming and integrating the foreigner, whether through political alliances, marriage, or conversion in irrevocably changed forms, Travels pushes encounters into embraces in its pursuit of Anglo-Persian hospitality. While in both Merchant and Othello hospitality between cultures and religions is thwarted despite the cosmopolitan reputation of Venice, in Travels, Persia provides a religious loophole, a means by which the playwrights can avoid the long-standing and multifaceted relationship among the People of the Book-Jews, Muslims, and Christians-to create unity in a pseudo-ancient Persia. With its pagan past in some instances more alive than its Islamic present, a tangible Persia exists, puzzling while providing early modern audiences with a distinct utopian setting to stage improbable receptions. Through its anachronisms and mediated forms of hospitality, the play parallels Persia and Venice in its diversity and potential for coexistence, claiming that the former can be even more hospitable to such opportunities than the latter, given the right circumstances. At the same time, because Shakespeare's Venice contingently and conditionally hosts Shylock and Othello, representative minorities of two cultural and religious traditions, its attempts at pluralism are potentially more radical (and devastating) than even the strides Persia makes in Travels. In reading these scenes of hospitality and hostility, it becomes clear that Shakespeare begins to adumbrate the conditions necessary for cosmopolitanism, and the Travels playwrights provide an arena and situation to activate those potentialities. As Shakespeare's Venetian plays negotiate unlikely unions that lead to changed worlds, Travels plays with the idealism of hospitality in far off lands, calling upon the audience to engender novel social realities by staging that which is hidden and potentially hopeful in Shakespeare. 


\section{Notes}

I would like to acknowledge the support of the UC Irvine Center in Law, Society, and Culture and its Peterson/Microsemi Fellowship program, which made preparation of this article possible. I am grateful for scholarly and editorial suggestions from Julia Reinhard Lupton, David B. Goldstein, Jane O. Newman, Bradin Cormack, Christopher Tomlins, Nedda Mehdizadeh, and Bret Kaufman.

1. See Samuel P. Huntington, The Clash of Civilizations and the Remaking of World Order (New York: Simon \& Schuster, 1996); David Cannadine, The Undivided Past: Humanity Beyond Our Differences (New York: Alfred A. Knopf, 2013); and Michael R. Karlberg, Beyond the Culture of Contest: From Adversarialism to Mutualism in an Age of Interdependence (Oxford: George Ronald, 2004).

2. This scholarly discussion on the interplay between cosmopolitanism and xenophobia in the period is long-standing and multifaceted, with recent contributions including Richard Wilson, "Making Men of Monsters: Shakespeare in the Company of Strangers," Shakespeare 1, no. 1 (2005): 8-28; Jean Howard, "Introduction: English Cosmopolitanism and the Early Modern Moment," Shakespeare Studies 35 (2007): 19-23; Barbara Sebek "Morose's Turban," Shakespeare Studies 35 (2007): 32-35; Jonathan G. Harris, "The Time of Shakespeare's Jewry," Shakespeare Studies 35 (2007): 39-46; and Carole Levin and John Watkins, Shakespeare's Foreign Worlds: National and Transnational Identities in the Elizabethan Age (Ithaca: Cornell University Press, 2009) among others.

3. Leah S. Marcus, "Provincializing the Reformation," PMLA 126, no. 2 (2011): 434.

4. Ibid., 435.

5. Julia Reinhard Lupton, “Re-vamp: A Response," PMLA 126, no. 2 (2011): 470.

6. William Shakespeare, Othello, the Moor of Venice, ed. Michael Neill (Oxford: Oxford University Press, 2006), 1.3.127, 128-130. All subsequent references will be to this edition and cited in text.

7. Laurence Publicover, in "Strangers at Home: The Sherley Brothers and Dramatic Romance," Renaissance Studies 24, no. 1 (2010), reads the play in terms of its allusions to "nationalistic" romances of the period: "this is not simply a question of digesting the strange, but of digesting the strange through theatre; material is so manipulated that it fits the palatable and familiar structures of dramatic discourse" (702-703). See also H. Neville Davies, "Pericles and the Sherley Brothers," in Shakespeare and His Contemporaries: Essays in Comparison, ed. E. A. J. Honigmann (Manchester: Manchester University Press, 1986), 94-113; Anthony Parr notes borrowings from The Merchant of Venice, in The Travels of the Three English Brothers by John Day, William Rowley, and George Wilkins (Manchester: Manchester University Press, 1995), 78; Bernadette Andrea identifies comparisons with Anthony and Cleopatra and Othello in "Lady Sherley: The First Persian in England?," Muslim World 95, no. 2 (2005): 284; Ladan Niayesh comments on similarities with The Merchant of Venice, Antony and Cleopatra, and Othello in "Shakespeare's Persians," Shakespeare 4, no. 2 (2008), 133.

8. Bonnie Honig, Democracy and the Foreigner (Princeton: Princeton University Press, 2001); Richard Kearney, Anatheism: Returning to God After God (New York: Columbia University Press, 2010), 40-56.

9. Jyotsna G Singh, A Companion to the Global Renaissance (Chichester: Wiley-Blackwell, 2009), 5. See Singh for a biography of recent work engaging with global notions of the Renaissance, including Jerry Brotton, The Renaissance 


\section{Sheiba Kian Kaufman}

Bazaar: From the Silk Road to Michelangelo; Lisa Jardine, Worldly Goods: A New History of the Renaissance; Nabil Matar, Turks, Moors, and Englishmen in the Age of Discovery; and Jonathan Gil Harris, Sick Economies: Drama, Mercantilism, and Disease in Shakespeare's England, among many notable others (25).

10. Biblical quotations are taken from the Geneva Bible (London, 1599) unless noted otherwise.

11. Quoted in Jane H. Degenhardt, Islamic Conversion and Christian Resistance (Edinburgh: Edinburgh University Press, 2010), 37. Degenhardt draws upon Gregory Kneidel's discussion of the challenges of Christian universalism in Renaissance England, and ultimately argues "how the early modern imagination Christian universalism was not all inclusive, how its very promise of universal faith depended on certain degrees of exclusion, and how Shakespeare reveals its limits in particularly canny ways" (40).

12. Émile Benveniste, Indo-European Language and Society (London: Faber, 1973), 71.

13. Kearney, Anatheism, 48.

14. Jacques Derrida and Anne Dufourmantelle, Of Hospitality: Cultural Memory in the Present (Stanford: Stanford University Press, 2000), 77, 25.

15. Kearney, Anatheism, 48.

16. See Immanuel Kant, Toward Perpetual Peace and Other Writings on Politics, Peace, and History, ed. Pauline Kleingeld, trans. David L. Colclasure (New Haven: Yale University Press, 2006), 82, emphasis added; Emeric Crucé, The New Cyneas of Émeric Crucé, ed. Thomas W. Balch (Philadelphia: Allen, Lane, \& Scott 1909), 302.

17. Crucé, The New Cyneas, 84.

18. In responding to commentators, Seyla Benhabib claims that "the orders of the unconditional and the conditioned are heterogeneous, but the ethical can and ought to inform the juridico-political. I seek neither totalization nor transcendence, to use Emmanuel Levinas's language, but mediation" in Another Cosmopolitanism: Hospitality, Sovereignty, and Democratic Iterations with essays by Jeremy Waldron, Bonnie Honig, and Will Kymlicka, ed. Robert Post (Oxford: Oxford University Press, 2006), 158.

19. Brian Treanor, "Putting Hospitality in its Place" in Phenomenologies of the Stranger: Between Hostility and Hospitality, ed. Richard Kearney and Kascha Semonovitch (New York: Fordham University Press, 2011), 50; see also Lupton, "Making Room, Affording Hospitality: Environments of Entertainment in Romeo and Juliet," Journal of Medieval \& Early Modern Studies 43, no. 1 (2013): "Hospitality bears on questions of space and its theatricalization insofar as entertaining involves making room for guests, both physically (where will they sit, slouch, sleep, eat, dance, or check their e-mail?) and existentially (the guest might be a ghost, or a kidnapper, or allergic to peanuts)" (146).

20. After years of academic neglect following Samuel Chew's The Crescent and the Rose: Islam and England during the Renaissance (1937), emerging scholarship has brought Persia out of academic obscurity, culminating recently in Jane Grogan's monograph, The Persian Empire in English Renaissance Writing, 1549-1622 (New York: Palgrave Macmillan, 2014). Scholars including Niayesh, Linda McJannet, and Chloë Houston have noted Persia's distinction among Islamic nations, particularly in relation to far more negative representations of the Ottoman Empire, and its resistance to a stable category of representation. Grogan discusses the problem of articulating discourses of "familiarity" rather than "otherness" that is the prevailing language scholars call 
upon to articulate cross-cultural encounters in critical definitions of the "global Renaissance" (7). Similarly, Jane O. Newman's work on the "rhetoric of sameness" and "similitude" in the writings of Hugo Grotius offers "alternative, less 'othering' discourses about Africa at the time," and pioneers the terms by which a less adversarial framework can be called upon in critical discussions of race. See “'Race,' Religion, and the Law: Rhetorics of Sameness and Difference in the Work of Hugo Grotius," in Rhetoric and Law in Early Modern Europe, ed. Victoria Kahn and Lorna Hutson (New Haven: Yale University Press, 2001), 285-317. I propose that dramatic iterations of hospitality through Persia, although not limited to its model, can offer a paradigm for understanding another instantiation of the global early modern.

21. Publicover, in "Strangers at Home," details the political ramifications of the brothers "troubling individualism," and writes that Anthony's tour around Europe as the Shah's ambassador was taken on without Elizabeth's permission; the Sherleys' Persian travels began in 1598 at the bidding of the Earl of Essex when Anthony Sherley left England to initiate "the long-cherished design of a league between Persia and Christian Europe" against the Ottoman Empire after consulting with Venetian merchants, 695-697. For biographical sketches of the Sherleys and their diplomatic actions, see David W. Davies, Elizabethans Errant: The Strange Fortunes of Sir Thomas Sherley and His Three Sons (Ithaca: Cornell University Press, 1967); Manoutchehr Eskandari-Qajar, "Persian Ambassadors, Their Circassians, and the Politics of Elizabethan and Regency England" Iranian Studies 44, no. 2 (2011): 251-271; Parr, "Foreign Relations in Jacobean England: The Sherley Brothers and the 'Voyage of Persia," in Travel and Drama in Shakespeare's Time, ed. Jean-Piere Maquerlot and Michele Willems (Cambridge: Cambridge University Press, 1996): 14-31.

22. William Shakespeare, "Twelfth Night, or What You Will" in The Complete Pelican Shakespeare, ed. Jonathan Crewe, general editors Stephen Orgel and A. R. Braunmuller (New York: Penguin, 2002), 2.5.172 and 3.4.267. For an historical overview of the reference to the Sophy in Merchant and Anthony Jenkinson's exchange at the court of Tahmasp I of the Safavid dynasty, see Bernadette Andrea, "Elizabeth I and Persian Exchanges" The Foreign Relations of Elizabeth I, ed. Charles Beem (New York: Palgrave Macmillan, 2011), 172.

23. David B. Goldstein eloquently questions unattainable ideals in Eating and Ethics in Shakespeare's England (New York: Cambridge University Press, 2013): "Where in Renaissance religious thought do we find an unadulterated sense of common humanity that transcends religious boundaries-or for that matter, national, cultural, racial, or sexual ones?" (77).

24. Publicover, "Strangers at Home," 701-703.

25. Grogan, Persian Empire, 28.

26. William Shakespeare, The Merchant of Venice, ed. Leah S. Marcus (New York: W.W. Norton, 2005), 1.3.96, 109-110. All subsequent references will be to this edition and cited in text.

27. John Day, William Rowley, and George Wilkins, The Travels of the Three English Brothers, ed. Anthony Parr, 1.53, 62. Subsequent references will be from this edition; scene and line numbers-there are no act divisions-will be cited in text.

28. Oxford English Dictionary Online, s.v. "tolerate, v.," accessed July 20, 2014, http://www.oed.com/view/Entry/ 202987; Oxford English Dictionary Online, s.v. "embrace, n.," accessed July 20, 2014, http://www.oed.com/view/ 
Entry/60977; Oxford English Dictionary Online, “embrace, v.2," accessed July 20, 2014, http://www.oed.com/view/Entry/60979.

29. Grogan, Persian Empire, 169.

30. Margaret Meserve's analysis of humanists' writings on Islamic empires and the search for the origin of the powerful Ottoman Turks emphasizes Persia's distinct place in European historiography and marks a telling enthusiasm for Persian kings resurfacing with the first Safavid king, Shah Ismail I, who is compared to Xerxes, Darius, and Alexander the Great, and figured as the "long-lost heir of Cyrus, the Magi, and Prestor John." See Meserve, Empires of Islam in Renaissance Historical Thought (Cambridge: Harvard University Press, 2008), 233-237.

31. Nora Kathleen Firby, European Travellers and Their Perceptions of Zoroastrians in the 17th and 18th Centuries (Berlin: Reimer, 1988), 17.

32. From the printing of Richard Hakluyt's Principal Navigations (1589) to Thomas Herbert's Some Yeares Travels (1634), travelers often comment on both contemporary and ancient Persia, particularly in descriptions of Persepolis: "this Citie continued mightiest in Asia from Cambyses, to Darius ... This Citie, saith Diodorus Siculus, was the richest and most louely City vnder the Sunne" (London, 1634), 57. Some travelers, including Herbert and Pedro Teixeira, an independent Portuguese traveler in Persia at the same time as the Sherleys, describe contemporary Zoroastrians as fire-worshippers: "they serve the sun, and fire which they preserve with great care" (quoted in Firby, European Travellers, 24).

33. Honig, Democracy and the Foreigner, 3.

34. Michael Neil, introduction to Othello, the Moor of Venice by William Shakespeare (Oxford: Oxford University Press, 2006): “The key word in this outburst-the one on which Iago's sense of violated proportion fixes, and which provides an indispensable clue to the social tensions that animate the play, is 'place""(148).

35. Niayesh in, "Shakespeare's Persians," explains that while it was known in Europe that by "Mortus Ali" the Sophy meant the son-in-law of Muhammad, the rightful successor according to the Persian Shi'as but rejected by the Turkish Sunnis, it is possible that "'Mortus,' for much of the audience, would have simply meant death (142). On the play's representation of the Mazdaist symbols of the sun and the moon derived from Zoroastrian theology, see Javad Ghatta, "'By Mortus Ali and Our Persian Gods': Multiple Persian Identities in Tamburlaine and The Travels of the Three English Brothers," Early Theatre 12, no. 2 (2009): 242. For an initial reading of Zoroastrianism, see Jenny Rose, Zoroastrianism: An Introduction (London: I. B. Tauris, 2010).

36. Nedda Mehdizadeh notes a "triangulation between England, Persia, and the Ottoman Empire" in the hybrid faith of the Persia court; the two characters that invoke sun worship, the brothers Halibeck and Calimath, "inhabit a middle space that is not quite Persian and not quite Turkic." "Translating Persia: Safavid Iran and Early Modern English Writing” (Ph.D. diss., George Washington University, 2013), 111.

37. Parr, Three Renaissance Travel Plays, 78; Andrea, "Lady Sherley," 284.

38. Tracy McNulty, The Hostess: Hospitality, Femininity, and the Expropriation of Identity (Minneapolis: University of Minnesota Press, 2007), xii, viii.

39. This scene also includes a mirroring of interreligious terms as Robert swears by the Persian sun, "Yon fire / That lightens all the world knows my desire / Durst never look so high" and the Sophy charges Robert to swear his loyalty 
by Christ: "By that first mover who thou call'st thy god, / The blest Messiah, and the sacrament / Which Christians hold so ceremonious (6.137-138, 178-180).

40. Parr, Three Renaissance Travel Plays, 101.

41. The play's consciousness of the "stage Jew" speaks to David Nirenberg's thesis on the proliferation of "so many imagined Jews on the new stages of London" that are independent of the insignificant "real" Jewish population in London in “Shakespeare's Jewish Questions," Renaissance Drama 38 (2010): 79.

42. Goldstein, Eating and Ethics, 89.

43. Daryl W. Palmer, Hospitable Performances: Dramatic Genre and Cultural Practices in Early Modern England (West Lafayette: Purdue University Press, 1992), 175.

44. Richard Wilson, Secret Shakespeare: Studies in Theatre, Religion and Resistance (Manchester: Manchester University Press, 2004), 275-276. See also Wilson, “'When Golden Time Convents': Shakespeare's Eastern Promise” Shakespeare 6, no. 2 (June 2010): 209-226.

45. Wilson, Secret Shakespeare, 276.

46. Parr, introduction to The Travels of the Three English Brothers, by John Day, William Rowley, and George Wilkins (Manchester: Manchester University Press, 1995), 17.

47. Maximilien de Béthune, Duke of Sully, The Grand Design in Europe: Giving Shape to an Idea, ed. Jorge T. Silva (London: Anthem Press, 2009), 58.

48. Kearney, Anatheism, 47; Lupton, Citizen-Saints: Shakespeare and Political Theology (Chicago: University of Chicago Press, 2005), 105.

49. Geraldo U. Sousa, Shakespeare's Cross-Cultural Encounters (New York: St. Martin's Press, 1999). I concur with Sousa's reading that in Merchant "the cross-cultural encounter becomes a textual experience" (71); however, while Sousa sees texts such as the bond and Portia's xenophobic Venetian decree against aliens as part of a "protective barrier" against foreigners, I believe that these documents serve as legal aids to maintain an alien presence in Venice, limiting in the immediate instance but ultimately dynamic because of the probability of unknown futures.

50. Aryeh Botwinick, "Shakespeare in Advance of Hobbes: Pathways to Modernization in the European Psyche as Charted in The Merchant of Venice," TELOS 153 (Winter 2010), 158.

51. Quoted in Neill, ed., Othello, 395.

52. Lupton, Citizen-Saints, 121.

53. Ibid.

54. Honig, Democracy and the Foreigner, 21.

55. Jonathan Burton, Traffic and Turning: Islam and English drama, 1579-1624 (Newark: University of Delaware Press, 2005), 16-17.

56. Daniel Vitkus, Turning Turk: English Theatre and the Multicultural Mediterranean, 1570-1630 (New York: Palgrave, 2003), 78.

57. Grogan, Persian Empire, 167. 


\title{
10 Hospitality in Twelfth Night Playing at (the Limits of) Home
}

\author{
Joan Pong Linton
}

Hospitality is a recurrent theme in Shakespeare, but nowhere does inhospitality so pointedly implicate the household as a social institution as it does in Twelfth Night through the figure of the stranger. In the opening scene, four survivors from a shipwreck make their ways into the society of Illyria, a place that, as Antonio warns Sebastian, "to a stranger, / Unguided and unfriended, often prove / Rough and unhospitable" (3.3.9-11). ${ }^{1}$ Antonio may be biased, since he is a known enemy to Orsino's men, and can walk abroad only at peril to himself. But as we learn towards the end, even the Captain, one "bred and born / Not three hours' travel from this very place," and familiar enough to catch its latest gossip (1.2.20-21), inexplicably ends up in prison. In truth, neither of Illyria's two noble houses seems ready to entertain strangers, the one headed by a nubile countess who has cloistered herself from the world, the other by an eligible duke occupied with entertaining himself. While Viola finds service with the Duke, Sebastian engages in the tourist's "mere extravagancy" (2.1.9-10), assuming roles that fit into Illyria's household and commercial economies. Sebastian is buying his right to be in Illyria, Viola is earning it. While neither requires hospitality, the issue remains latent in the play's persistent interest in strangers and "domesticating strangeness," 2 to borrow a term from Catherine Lisak's essay and title.

According to Felicity Heal, in early modern English the term stranger "was used with equal regularity" both "as a description of the alien who was unknown" and "as a term of domestic art, to describe an individual who was not attached to a particular familia." ${ }^{3}$ In this context, the hospitality extended or withheld was household hospitality; that is, hospitality grounded in the patriarchal household economy with its gender and property relations conceptually unified around the male host as owner. To contemporary audiences, Viola and Sebastian would be strangers in both senses, and they are domesticated through marriage into Illyrian families. In her analysis, Lisak attends to strangeness in terms of characters' deviations from social norms, and the ways in which "Illyrians take it upon themselves to tame or hold at bay strangeness." 4 Strangeness thus defined pertains to insiders as much as outsiders, including the households of Orsino and Olivia. I would suggest that the romantic comedy's conventional expectations are at work here motivating the characters and drawing the play toward domestic 
closure in marriage-but with a twist. Specifically, the play's drive toward marriage and domestication stalls at the last moment on two discoveries. First, the twins' reunion leaves no doubt that Olivia has married a total stranger; and second, the absence of Viola's “woman's weeds" suspends her nuptial and recalls the stranger in her whose integration into Illyrian society thus remains deferred (5.1.265). Into this suspended closure steps Feste singing about, among other things, fearful householders who "shut their gates," excluding strangers as "knaves and thieves" (5.1.382).

This jarring of conventional expectations, with underlying household anxieties exposed by Feste's song, confronts the audience with the family as the social institution that functions to include strangers by marriage or exclude them as threats to household property. Since inclusion bypasses hospitality, and exclusion withholds it, we come to realize that at the heart of Illyrian inhospitality is the inability to countenance the stranger as stranger, irreducible to the self, be it the foreigner or familial outsider, or the stranger within oneself. Insofar as social roles reinforce normative expectations and obligations, they function to define identities and regulate behaviors within a social network. However, social roles cannot prevent their bearers from straying beyond the boundaries they define, no more than they can fix individuals' identities and behaviors. In this light, the stranger becomes the paradigmatic figure of the otherness in us all that exceeds the social roles we perform and the capacity of the household to contain. It is the stranger's irreducibility to the self that haunts Illyrian society, in a play that sets up encounters, disguises, and unveilings as occasions for posing the question of hospitality and imagining its possibilities at the limits of the household.

I focus on two encounters in particular, each connected with a biblical subtext that serves to provide implied commentary for a culture conversant with scripture in diverse venues, from the pulpit to private devotions. The first encounter concerns Olivia, whose refusal to play hostess, coupled with her quick about-face in unveiling herself to the disguised Viola, furnishes the comic action through which the play problematizes household hospitality from the perspective of its female protagonists. Such action finds its latent seriousness in the subtextual story of Susanna and the Elders, revealing the hostess's dispossession as the object of sexual possession. The second instance concerns Paul's anticipated face-to-face encounter with the divine, which Feste invokes in his final song, recalling the play title's suggestion of seasonal hospitality ${ }^{5}$ associated with the coming into the world of Christ as the quintessential stranger, the Messiah dispossessed of his divinity in assuming humanity. In my analysis I am interested in the possibilities of an alternative hospitality that enacts dispossession as a performative ethics between strangers, and its implications for an ethics of performance for theater in its diverse venues, entertaining strangers at every turn.

To understand Olivia's inhospitality we need to go behind closed doors to witness her situation as head of her household. Despite her vow to abjure male company, her uncle has invited in a would-be suitor in order to fleece 
him; her steward would "be Count Malvolio," bedding her and lording over her household (2.4.30); and even her clown is not above playing "Pandarus," taking money at the gate (3.1.45). These designs on Olivia's person by her male dependents as their means to wealth reveal her vulnerability as the unmarried head of an aristocratic household in disrepair-a household with no intact boundaries. In this sense the strangers are already in the house, these familiar faces whose mercenary motives and transactions have thoroughly infiltrated its social space, and redefined her as property up for grabs, turning any semblance of hospitality into a form of prostitution.

In theorizing the position of the hostess and of the feminine within what she calls the "hospitality relation," Tracy McNulty writes:

In archaic practice, as well as in biblical narratives, feminine participation in the hospitality act is often limited to the exchange or offering of women between men. In both contexts the host's wife and daughters are considered not as subjects, but as his chattel: dependent "things" that make up the host's personal property as master of the home. ${ }^{6}$

In this way sexual possession becomes a thing to give and exchange in the dealings between host and guest. As McNulty clarifies, "in insisting on the 'thingly' status of woman in the hospitality relationship," the point "is not so much to denounce the objectification of women in a male economy but to examine the agency and ethical status of this positioning." ${ }^{7}$ McNulty goes on to draw two important implications: first, regarding the status of woman as the host's property, "that she is able to act as an extension of the host's personhood"; and second, regarding female property, that in "being both identified with and in excess of the male master and host, ... it is able to facilitate reciprocal relations between men, such as the relationship of mutual obligation that often binds the host and guest following an initial act of hospitality." 8

These functions of the hostess present in archaic practice and biblical narratives would seem to persist in the medieval European literary tradition, most visibly in the courtly and chivalric romances, including the French Arthurian tradition and its English offshoots, where hospitality and the traffic in women are thematically linked. In these stories, hospitality scenes are often fraught with uncertainty, since they involve exchanges between perfect strangers and therefore an element of risk. As Ad Putter points out, the elaborate protocol of hospitality detailed in these romances and in contemporary conduct books reflects a felt need to regulate hospitality exchanges in order to minimize "ambiguity and potential conflict." Protocols cannot eliminate anxieties, however, since "codified etiquette can be consciously acted and dissembled." ${ }^{9}$ Here the figure of the stranger takes on additional freight of hidden motives and hostile intentions. In a system where women mediate as property in the exchange between men, masculine anxieties come to focus on the hostess whose uncertain virtue may undo host or guest, or both, and on the unattached hostess who flouts all rules of hospitality. 
In a text like Sir Gawain and the Green Knight, not only is the hostess an extension of the host's personhood, but her wifely virtue becomes central to hospitality's intertwined and multilayered social relations grounded in the patriarchal institution of property. Gawain's trawthe and his pentangle virtues are put to the test in three days of luftalking and courtly seduction by his hostess and exchange of winnings with a host, all undertaken in the name of hospitality. When Gawain is caught keeping a gift from the hostess (for love of life, and not for cunning or courtship), which the host finds forgivable, the gift as "female property" seals a new bond between the Green Knight and Gawain, who then learns that his hostess has all along served her husband faithfully. The same concern with the hostess's virtue becomes a symptom of male anxiety that Shakespeare explores, typically in tragic mode, in instances where a virtuous hostess is victimized through the failings or absence of the host. Thus Lucrece is raped for her virtue, of which her husband has boasted before other men, and the tragedy that begins The Winter's Tale results from an overly jealous host who misreads his wife's hospitable gestures as signs of her sexual infidelity with a guest who thus overstays his welcome. The pattern recurs in Cymbeline, which the first Folio classifies as a tragedy. Imogen is betrayed by a husband who bets on her virtue, provides his opponent access to her hospitality, believes without investigation the latter's false proofs of her infidelity, and in jealousy plots her death. Between the lies of the guest (who likens her to Lucrece and Philomel) and the credulity of the absent host, the hostess's person is reduced to a personal effect (the stolen bracelet) and an anatomical detail (the mole on her breast accidentally glimpsed)—a man's possession, by marriage or by stealth.

The "thingly status of woman in a hospitality relationship" remains at issue in a comedy like Twelfth Night, albeit submerged in laughter. Olivia would seem to enjoy a measure of autonomy as hostess of a house without a male host, but as we have seen there is no lack of parodic substitutes who would play the keeper of Olivia's body as property to be used how they will. All this takes place unbeknownst to Olivia, of course, in comedy's grand style of carnival misrule; indeed, much of the comedy depends on her remaining blithely oblivious until the play's end of what goes on behind her back. The effect is to provoke not only laughter at the shenanigans as they unfold but also judgment of the characters, since the laughter is, after all, premised on our judgment that household authority and hospitality are being misappropriated and abused. As new household arrangements are configured out of the old, and hospitality relationships are reinvented, the one structural constant is the hostess's position as the (present, absent, or would-be) host's presumed property and sexual offering to a guest.

At the same time, the play approaches the hostess's precarity through a biblical subtext linking Olivia's situation with the story of Susanna and the Elders, an apocryphal story from the Babylonian exile. Susanna's husband, for all his wealth and fame, is unable to protect her from the lecherous elders and the harshness of miscarried justice. Likewise, Olivia's dead father and 


\section{Joan Pong Linton}

brother are powerless to protect her from the predatory intentions of her own male dependents. The apocryphal story of Susanna enjoyed enormous popularity in Europe and England. In "liturgical preaching" throughout the patristic, medieval, and Byzantine eras, she was the most important among female biblical figures whose exemplary virtue substantiated the Christian doctrine of the spiritual equality of the sexes." ${ }^{10}$ Ambrose, Tertullian, Augustine, and Abelard present her as an exemplar of chastity. ${ }^{11}$ In England, the Susanna story had a long popular tradition in sermons: "If a medieval Christian went to church on the Saturday before the third Sunday in Lent ... he or she would hear read as the epistle for that day the entire account of Susanna from Daniel 13." ${ }^{2}$ The story "appeared in a variety of forms in Renaissance England: popular wall pictures, ballads and drama." ${ }^{13}$ According to Tessa Watt, Susanna was one of the four most popular subjects of biblical wall paintings, ${ }^{14}$ and while diverse factors may account for the story's popularity, the appeal of the ballad versions "lay in the image of naked Susanna washing herself in the orchard, an object of fantasy which probably titillated the viewers of Renaissance paintings on the theme just as much as it did the wicked elders whose lechery was supposedly condemned." 15 Then, too, the story may have had special appeal for Shakespeare and his wife, who named their firstborn Susanna.

In Twelfth Night, Olivia is specifically linked to Susanna through Sir Toby's drunken singing: "There dwelt a man in Babylon, lady, lady" (2.3.71). The first part of the line directly replicates the first line from both chapter 13 of the Book of Daniel and the "Ballad of Constant Susanna"; the words "lady, lady" form the refrain in sixteen of the ballad's nineteen stanzas. ${ }^{16}$ In citing "lady, lady," the play both refers to Susanna as a household name and connects the biblical heroine with the title Olivia most frequently goes by within her household. That this subtext should emerge during Toby's carousal with Sir Andrew further indicates the business Toby has in mind, although the two men never come close to the enormities that the lecherous elders perpetrate. Another set of parallels comes from Thomas Garter's Commody of the moste vertuous and Godlye Susanna (1578), a moral play that allegorizes the elders as Sensualitas and Voluptas. These include the comic treatment of "matters grave and sad" (Pro. 1. 19); the clock strike which Susanna's servant takes as a warning "for losing of the time" (1l. 645; 708; cf. Olivia in III.i.122: "the clock berates me with the waste of time"); the name Toby for Tobit, which Susanna's father invokes as one whom "God himselfe did ... alwayes ayde / And sent him home his sonne agayne" (1l. 890-91); and Ill Reporte's play on his name William to produce "ill will" (11.1124-37; cf. the name Malvolio). A third connection concerns Olivia's order to "let the garden door be shut" (3.1.84), which echoes Susanna's words in Daniel, "and shut the garden doors" (Daniel 13:17). ${ }^{17}$ A fourth connection comes through a speech by Viola calling on Time to untie the romantic knot in which she is caught. Viola's "alas the day" (2.2.36) echoes the biblical voices of Joel and Jeremiah chastising their community for its corruption and 
prophesying Israel's delivery from exile. ${ }^{18}$ In speaking out against "wicked counsel," Jeremiah singles out Ahab and Zedekiah as "false prophets" and "adulterers" (Jer. 29.20-23), the very judges who are Susanna's accusers, according to Jerome and the Wycliffite tradition in England. ${ }^{19}$

There is, to be sure, a noticeable disproportion between text and subtext in these instances, that is, between Toby's misrule and the elders' miscarriage of justice, between Toby the riotous uncle and Toby the pious father, between Olivia preparing to woo Cesario and Susanna to wash herself; and between Viola's wish to be delivered from romantic entanglement and Israel's deliverance from exile. The disproportion is great enough to suggest parody operating both locally to produce comic effects and collectively to draw attention to the story being parodied. The parody works precisely because we need not assume a direct parallel between text and subtext; at the same time, there is enough of a connection to make the differences purposeful and productive. Within biblical tradition, Susanna is one of the female figures whose exemplary virtue proves instrumental to challenging or reaffirming established institutions. For resisting rape, Susanna is tried in public by the elders whose abuse of hospitality thus locates the household in a larger arena of political theology. In particular, the story "challenges the traditional legal method by which two witnesses could falsely accuse a man and their testimony was accepted as true" without cross-examination. ${ }^{20}$ Susanna is herself defenseless against this legal method, especially since her false accusers are the very judges and witnesses in her trial, and this legal miscarriage of justice is foregrounded throughout the story. Susanna is acutely aware of her victimization, and she twice cries out "with a loude voyce" against the elders, the first time to summon help to prevent her imminent rape, and the second to God to deliver her from injustice and imminent death (Daniel 13.24, 42). In English communities the image of Susanna as the chaste woman who speaks out against injustice had a particular appeal across temporal, gender, and religious differences. ${ }^{21}$ In particular, the fourteenth century alliterative poem, A Pistel of Susan, launches "a sharp critique of a legal and social system where false witnesses can malign and doom the vulnerable." ${ }^{22}$ In this context, Susanna's story is applicable to Olivia's situation in pointing to the built-in injustice of social and legal practices that, recognized as the norm or law, inevitably produce victims, whether or not the victims are aware of their situation.

The Susanna subtext further participates in a pattern of biblical and religious echoes in the play, often misappropriations readily noticeable by an audience familiar with the sources. Some of the misappropriations reflect comically on their speakers, as when Andrew calls Malvolio Jezebel (2.5.36), and when Toby cites 2 Corinthians, "let us therefore eat, drink," leaving out the words immediately following: "for tomorrow we die" $(2.3 .11 ; 1$ Corinthians 15.32). Other echoes tamper with religious rituals, as when Toby and his accomplices, pretending to cure Malvolio of his madness, address him in the language of exorcism. Religious ritual is thus mocked 
by being repurposed for a mean-spirited prank, playing on both the contemporary belief that madness is a symptom of demonic possession and the Protestant hostility to exorcism as a Catholic ritual. ${ }^{23}$ Together, these parodic misappropriations provide the context for Olivia's first meeting with Viola disguised as Cesario, an encounter in which Olivia's household problems find indirect airing through the interweaving of religious and secular rituals.

In this meeting, a courtly love message is delivered through the ritual of catechism. Olivia has just come away from speaking with Feste, who ventured to "catechize" her for her excessive mourning (1.5.54). She now turns catechist, addressing Cesario as her catechumen, examining him/her on the "lesson" that he had "taken great pains to con" (1.5.154-155). Professing that she would "hear this divinity" and "comfortable doctrine," she asks Cesario, "Where lies your text?" (a cue for the catechumen to respond by citing chapter and verse from the bible). When Viola replies that it has come from "the first [chapter] of [Orsino's] heart," Olivia pronounces it "heresy," a well-worn topos that keeps up the banter $(1.5 .193,197,200,201)$. This catechistic mockery of the courtly ritual builds up to Viola's request, "Let me see your face" (1.5.202), words that transgress both ritual and social barriers between them, releasing Viola from the role of courtly go-between and Olivia, in complying with the request, from the role as court lady. This moment of unveiling is powerful on several registers, unfolding as it does in layers of parodic revelation.

First, in unveiling her face, Olivia declares that "it shall be inventoried, and every particle and utensil labeled to my will: as, item, two lips, indifferent red; item, two grey eyes, with lids to them; item, one neck, one chin, and so forth" (1.5.216-218). Her inventory mocks the blazon as a device that turns the lady into a cypher of the courtly lover's economic and political ambitions-the veil behind which the lady becomes a version of McNulty's "hostess [who] is often cast as bereft of individual identity ... an indeterminate thing rather than an integral moral person." ${ }^{24}$ Second, Olivia's itemized list "labeled to my will" mimics "the legal document containing instructions about the disposal of her property." 25 The effect is to reduce her facial features to the household items that a woman legally owns. In this connection, Olivia's follow-up question, "Were you sent hither to praise me?" (1.5.218) may well be asked in the spirit of a shared joke, but not without underlying pathos, if we realize how little in control she is of her bodily inventory. As Dympna Callaghan points out, "Olivia cannot know that in the very next Act, without her consent, her private parts will be on display for everyone's amusement." ${ }^{26}$ In a borrowed hand, Olivia's maid will publish her will: "will" in the sense of her sexual desire and her genitals spelled out by Malvolio, "her very C's, her U's and her T's and thus makes she her great P's" (2.5.78-79). Earlier we've observed her male subordinates turn her into disposable property; here her maid takes away from her what she considers most intimately hers to give. If Maria's forgery estranges Olivia from her own will and body, it only makes explicit how much Olivia is a stranger 
in her own house alienated from its ownership. Olivia's dispossession gives new meaning to her remark, "ourselves we do not owe" (1.5.280), referring to her lack of self-possession, having fallen for one she has just met and takes to be a suitor's servant. The verb "to owe," with its dual sense of having and owing in Elizabethan usage, also calls attention to a system of social and sexual relationships, including those pertaining to hospitality, grounded in the patriarchal household economy, in which the hostess is at once obligated to others and dispossessed of herself.

The verbal violation perpetrated by Maria's forged letter and Malvolio's voiced fantasy, coming only two scenes after hearing Toby's allusion to Susanna, calls to mind the elders' false accusation of Susanna. With this, we come to a third parodic register in Olivia's unveiling, which echoes Susanna's unveiling at her trial, an order imposed by the elders "that thei might so be satisfied with her beautie" (Daniel 13.32), before sentencing her to death. Remarkably, at this point where Olivia seems most directly to connect with Susanna, the text also most decisively diverges from its subtext. For Susanna, the unveiling is deeply and publicly shaming, but it also sets up for her full vindication when Daniel proves the elders liars and Susanna guiltless of their accusation (of adultery with an unidentified young man). By contrast, Olivia unveils without shame if only because, for once, someone has breached decorum to express an interest in her as a person quite apart from her social position.

That Cesario is in fact a cross-dressed Viola requires some discussion, because it is central to the plot's complication, and this centrality implicates theater in the fourth parodic dimension of Olivia's unveiling. While Olivia takes Viola for Cesario for almost the entire play, it is Viola who has, from the start, engaged Olivia with a theatrical sense of self. To Olivia's host-like inquiries, "What are you? What would you?" Viola answers with a play on the courtly trope of secrecy, "What I am, and what I would, are as secret as maidenhead" (1.5.187; 189-90). At the same time, she also answers like an inexperienced and self-conscious actor: "I have taken great pains to con it [her speech]"; "that question's out of my part"; "I am not that I play" $(1.5 .154-155 ; 158-159 ; 164)$. This self-conscious performance targets the scripted nature of their exchange, and from her responses Olivia clearly catches on: "Are you a comedian?" and "If I do not usurp myself, I am [the lady of the house]" $(1.5 .162 ; 166)$. The effect is to translate the hostguest ritual Olivia initiates into the practice of theater, and this in turn sets up for Olivia's catechism as Cesario's mock initiation into the courtly performance we have seen earlier. It is this theatrical sense of self Viola brings out in Olivia that enables the latter to open herself to experience in the moment and to disclose-discover-her own strangeness as the lady of the house who does not own herself. Olivia is in effect opening herself to a new kind of hospitality and home-making with her new-found playmate.

For Viola's part, a theatrical sensibility defines her condition as a stranger in search of a home in Illyria. She would have served Olivia, but, the option 
being closed, decides to serve the Duke instead, assuming male disguise. As we can see, the process is not entirely her own making and entails unintended consequences, but it is this sense of not being in control-of not owning the process-that allows her, and Olivia, too, in their interaction, to let go of the social roles they inhabit and the ritualized practices they mock. To be sure, no one really owns the social process, although some may have more control over their own and other people's choices. The difference in Viola and Olivia's case is that they are willing to go off script, if only for a moment. In doing so they produce a lived sense of come what may that propels their play beyond conventional social and dramatic expectations. Their shared levity belies a deeper sympathy, each taking a chance at living in what is virtually a man's world without the protection that a brother could provide. Face to face, their mock theatrics translates into a moment of improvisational play that mocks the world they live in, a co-production in which each brings "home" the stranger as an anagrammatic other.

In building on each other's wit and pleasure, Olivia and Viola's improvisation goes beyond mockery as implied social critique to enact a mutually hospitable relationship. Realized in the performance, and carried by the fun of the moment, this alternative hospitality undoes the host-guest relationship to reposition them as strangers to one another in at least three senses. First, despite their similar losses they have no shared personal history or network of familial support. Second, in disowning the social roles by which they are known in Illyria, they disclose selves that exceed those roles. And third, each encounters in the other a strangeness she has helped to actualize in the spirit of play. Without each other Viola can no more become Cesario than Olivia a desiring subject. The process of self-transformation and discovery is intersubjective and relational, with the stranger one encounters and the stranger one becomes both transcending the devices of theatrical counterfeiting-Olivia's unveiling, Viola's disguise-from which each arises. In this light, openness to the stranger in oneself and in the other is the "home" and hospitality they have improvised for each other. "Home" as such is not a physical place, but is rather the projection of ethos in its root sense of dwelling or abode, the "opening of the familiar to the unfamiliar." 27

In its root sense, then, ethos as home remains active if suppressed in the dominant, proprietary sense of home and, as such, enables hospitality as an ethics of dispossession. To be sure, dispossession is often privative and oppressive, but as Judith Butler and Athena Athanasiou point out, it can also be relational, as when individuals dispossess themselves of normative roles and values organized around the "sovereign and unitary subject" and its operational "logic of possession." ${ }^{28}$ In opposing privative forms of dispossession, Butler and Athanasiou propose that we "think about dispossession outside of the logic of possession," because for them "ethical and political responsibility emerges only when a sovereign and unitary subject is effectively challenged." ${ }^{29}$ In Olivia and Viola's case, relational dispossession engenders a performative ethos in which hospitality no longer revolves 
around the home as property and the host as owner but around the relationship between dispossessed selves, individuated from yet radically in sympathy with each other, as their anagrammatic names assert, a relationship that requires no hostess to mediate.

To be sure, this performance of "unhomely" hospitality lasts but a moment, before both characters rejoin their social script and comedy's marriage plot, with Olivia advancing upon an alarmed Viola who retreats behind courtly platitudes. But the fact that the unveiling should happen at all, and between them, suggests the play's dialogical impulse in bringing its female protagonists into co-productive play that, while it lasts, transgresses the limits of home and hospitality normatively conceived and practiced. Here we see the creative potential of the performative, as Butler suggests: "As much as 'performativity' exposes the normativity of certain kinds of descriptive claims, it also offers a way to think about how new discourse can emerge precisely where it was not already legitimated." ${ }^{30}$ Although there is as yet no recognizable space in social practice for the home and hospitality Olivia and Viola have co-produced, their encounter inhabits, in Foucault's terms, the "interstice" or "non-place" made possible by theater, between text and subtext, in the felt sense of comic disproportion, the mocking imbrication of religious and social rituals. ${ }^{31}$ In this sense, Twelfth Night speaks to McNulty's "thesis that the feminine contests the autonomy of the host by giving voice to the alterity within [the host's masculine] personhood, functioning as the internal marking of the Other." ${ }^{32}$ Such alterity within personhood, then, locates the transgression of household hospitality at the heart of "personation," theater's defining practice. To lay the groundwork for this discussion, we must first examine the theological dimension that the play builds into the theatrical encounter. With this, we turn to yet another subtextual unveiling-the anticipated face-to-face encounter Feste invokes in his closing song. ${ }^{33}$

When that I was a little tiny boy, With hey, ho, the wind and the rain, A foolish thing was but a toy, For the rain it raineth every day.

But when I came to man's estate, With hey, ho, the wind and the rain, 'Gainst knaves and thieves men shut their gate,

For the rain it raineth every day.

But when I came, alas, to wive, With hey, ho, the wind and the rain, By swaggering could I never thrive, For the rain it raineth every day.

But when I came unto my beds, With hey, ho, the wind and the rain, 
With tosspots still had drunken heads, For the rain it raineth every day.

A great while ago the world begun, With hey, ho, the wind and the rain, But that's all one, our play is done, And we'll strive to please you every day.

In Feste's song, the opening lines from the first two stanzas- "When I was a tiny little boy" and "When I was come to man's estate"-echo Paul's words in 1 Corinthians: "When I was a child, I spake as a childe, I understode as a childe, I thought as a childe; but when I became a man, I put away childish things" (13:11). The echoed verse is the first half of an oft-quoted analogy: "For now we see through a glasse darkely: but then shal we se face to face. Now I knowe in parte: but then shal I knowe euen as I am knowen” (13:12). The entire chapter surrounding those verses dwells on love, culminating in the final verse: "And now abideth faith, hope \& loue, euen these thre, but the chiefest of these is loue" (13:13). Throughout the letter, Paul's message of love comes with his rebuke of the Corinthians for setting divisions among themselves: "And I colde not speake vnto you, brethren, as vnto spiritual men, but as vnto carnal, euen as vnto babes in Christ" (3:1). Becoming spiritual would require the love that heals divisions, as Paul explains,

For ye are all the sonnes of God by faith, in Christ Iesus.

For all ye that are baptized into Christ, haue put on Christ.

There is nether Iewe nor Grecian: there is nether bonde nor fre: there is nether male nor female: for ye are all one in Christ Iesus.

(Galatians 3:26-28)

The practice of love includes hospitality: "contribute to the needs of the saints" (Romans 12:13); "Be not forgetful to lodge strangers: for thereby some haue receiued Angels into their houses vnawares" (Hebrews 13:2).

Like Paul's Corinthians, the worldlings in Feste's song are carnal men, subjects of the flesh, and here the relation between text and subtext is no longer parodic but proportional. Feste sings as one well past his boyhood years yet remains mired in the carnal worries of "man's estate": for "'gainst knaves and thieves men shut their gate"; or when one "came to wife" but "by swaggering could I never thrive," hinting at marital disappointment and even sexual betrayal $(5.1 .382 ; 384 ; 386,388) .{ }^{34}$ These lines may address the experience of itinerant actors, peddlers, and vagrants who for lack of resources fail to marry and set up house, and as strangers are taken for thieves and knaves. The same lines may also speak to householders who fail to extend hospitality for fear of loss and cuckoldry. Taken separately, either reading would reinforce the distrust and failure that haunt Illyrian housekeeping, with ownership of property and women dividing haves from 
have-nots. Taken together, the readings would heal the division by virtue of linguistic ambiguity, confounding identities that are positioned as polar opposites within the household economy.

Feste's song ends on a pessimistic note, the final stanza locating Illyria within the history of "the world begun" from "a great while ago," a world that has endured endless cycles of inhospitable weather (5.1.392). Yet in its Pauline echoes the song holds open the possibility of atonement, consistent with Paul's instruction for the end time: "Circumcision is nothing, \& vncircumcision is nothing, but the keeping of the commandments of God. / Let euerie man abide in the same vocation wherein he was called" (1 Cor. 7:19-20). In the end time, divisions will no longer separate people; as Giorgio Agamben explains, the messianic call will transform them from within, resulting in "almost an internal shifting of each and every worldly condition by virtue of being "called""; operating beyond the logic of possession, "the messianic vocation is not a right, nor does it furnish an identity; rather, it is a generic potentiality [potenza] that can be used without ever being owned." 35 Through Paul, then, Feste delivers, to extend Sheiba Kian Kaufman's term, a "narration of hidden hospitality" (anthologized in this collection) to listeners on stage and off, calling them as they are to their messianic potential.

The song is remarkable because Feste is replicating at the level of linguistic performance the messianic vocation that Paul describes, and this suggests the theological engagement with scripture, conscious or otherwise, that informs the play as a whole and Shakespearean theater more broadly. Agamben's reading of the messianic in Paul is, again, instructive here. First, the transformative dimension of the messianic vocation operates as kairos in the "recapitulation of the past (... an abbreviated, summary chronos)" producing "a plèroma, a saturation and fulfilment ... that anticipates the eschatological plèroma when God 'will be all in all." "36 Second, the messianic kairos is oriented to the present, not the future, although a present uniquely open to the future. Agamben draws from Walter Benjamin's notion of Jetztzeit, the "now-time" or "actuality" in the now, in which the past becomes intelligible as a "historical index," being grasped in the specificity of the present as a call to thought and action that endows the present with a weak messianic power. ${ }^{37}$ Third, the messianic operates by way of profanation, which Agamben differentiates from secularization. Whereas secularization marks something as sacred for exclusive use by a few and preservation of a "power apparatus," profanation "restores something like a natural use that existed before being separated into the religious, economic, or juridical sphere," in doing so "mak[ing it] available for a new use." ${ }^{38}$ Put another way, "whereas secularization ... transfer[s] sacred things from one jurisdiction to another, profanation ... 'absolve[s]' sacred things from priestly and secular building codes alike, for new, inoperative, rehearsals (as art, festival or theater)."39

In its Pauline echoes, then, Feste's song recapitulates a messianic awareness that is already present in the play, one that is in fact part of the cultural imagination of Susanna as a figure of Christ, reinforced by a long 
tradition of Gospel typology and Lenten sermons. ${ }^{40}$ Coming at the end of the play, this recapitulative turn reframes both Susanna's story and Paul's message as historical indices to which Olivia (improvising with Viola) and Feste (improvising on Paul) form part of a fictive "constellation" that materializes for the audience, in Benjamin's terms, as "a now-time shot through with splinters of messianic time." 41 This fictive constellation includes the other characters as well, insofar as their parody of scriptural sources also prompts the audience to retrospection. Synergistic parody thus functions as the play's profanation of scripture, one way of reclaiming for hospitality the encounter with, and accommodation of, the stranger that opens theater, as a worldly vocation, to its potentialities. Where theology and theater converge, this latent history constitutes a Shakespearean cultural matrix from which characters are styled in their individuated dispositions to the world, in ways that surprise the economy and necessity of the Aristotelian plot. ${ }^{42}$

The urgent, recapitulative force of messianic time operates in the play as a whole, through its rendering of time as an embodied experience, what Feste retrospectively figures as "the whirligig of time" (5.1.364). Specifically, time seems to have stood still with business as usual in Illyria until a clock strikes in act 3 , scene 1 , when the action begins to accelerate toward the end, and then to stop just short of a nuptial ending. ${ }^{43}$ The clock strike, we may recall, occurring soon after Olivia/Susanna orders the garden gate to be shut, is for Olivia a call to action, and it renders the audience time-conscious amid converging lines of action hastening the play's dénouement. In analyzing "timely affects as a key feature of hospitality" in King Lear, in his chapter for this collection, Thomas J. Moretti writes: "At one moment, [Shakespeare] accelerates dramatic action and poetic output to heighten theatrical affect and to delight audiences; just as suddenly, he slows tempo to make the theater inhospitable enough for insight, depth, and awareness." Moretti's purposive deployment of "hospitable time" and "inhospitable time" is relevant to Twelfth Night, for in taking the audience through the "hospitable time" of a whirligig ride, the play just might end up with its stalled nuptial taking the prize as a limit case of "inhospitable time" by indefinitely suspending expectations of comic closure at the play's end. But if we consider that the nuptial functions ritually to integrate the household by appropriating the stranger, then the deferred nuptial effectively suspends this ritual force of integration and appropriation. In thus disrupting "homely" or household expectations, Shakespeare's theater is not inhospitable but differently hospitable, a difference Feste drives home when he engages the audience with the "unhomely" hospitality of messianic atonement, opening the self as home, beyond possessiveness, to the stranger. Recapitulating history since "the world begun" in the whirligig spin to the finish, Feste's song situates the play's suspended closure in the now time of the audience's messianic awareness, at the end of Twelfth Night festivities, on the threshold of an epiphany.

Hospitality as an unhomely practice has its place, then, in Shakespearean theater's complex production of pleasure and reflection. This is crucially 
the case in a play that problematizes household hospitality as the presumed model for hospitable practices; and specifically so where the encounter with and accommodation of the stranger are provocatively and metatheatrically focused on the practice of personation. In this respect Twelfth Night connects with the contemporary discourse and debate on theater, bringing a messianic dimension to an emerging interest in characterization. Andrew Gurr has shown that this art of characterization came with the professionalization of actors, noting in particular the shift in terminology from "playing" to "personation":

The term, the noun "personation," was suggestive of a relatively new art of individual characterization, an art distinct from the orator's display of passions or the academic actor's portrayal of the character-types.... The first use of the term was recorded in 1599-1600, at the end of the great decade in which Alleyn and Burbage made their reputations. ... By 1600 characterization was the chief requisite of the successful player. ${ }^{44}$

Louis Montrose further connects the concept and practice of dramatic personation to "other material and ideological developments ... that manifested the emergence of what we now characterize as merchant capitalism and bourgeois subjectivity." 45 Dramatic personation thus relates to a notion of personhood grounded in a household economy with its logic of possession, its proprieties and exclusions, aligning with an increasingly commercialized society.

The relation is an inverse one, insofar as the art of individual characterization, requires the actor temporarily to undo the possessive boundaries of personhood in becoming the character he plays. Thus Richard Flecknoe praises Richard Burbage as "a delightful Proteus, so wholly transforming himself into his part and putting off himself with the Cloathes, as he never (not so much as in the Tyring-house) assum'd himself again until the play was done." 46 In his Apology for Actors (1612), Thomas Heywood extols the actor's skill in the performance of English history, "what English blood seeing the person of any bold English man presented and doth not hugge his fame, and hunnye at his valor, pursuing him in his enterprise with his best wishes, and as beeing wrapt in contemplation, offers to him in his heart all prosperous performance, as if the personater were the man personated." 47 In the skillful production of a theatrical person, then, the actor achieves an ethos that blurs the line between self and other, host and guest, not unlike the relational dispossession Olivia and Viola undergo in co-producing hospitality. Indeed, Heywood's "all prosperous performance” ambiguously includes the spectator as co-producer in the personation, locating character as "the corporeal product of an intersubjective communication between actor and audience." ${ }^{48}$ Artistic skill has little appeal for theater's detractors, of course. John Cocke in "The Character of a Common Player" mocks his subject 


\section{6}

as a commercial opportunist, "a shifting companion: for he lives effectually by putting on, and putting off." 49

Yet it is significant that, just when theater was establishing itself as a commercial and cultural institution, skill in personation should be aligned with an ethic of dispossession, and that Twelfth Night should locate this ethic in the performance of an unhomely hospitality. In Olivia and Viola's encounter, such performance is in fact a staging of the theater's foundational practice, which begins with an actor's coming into character by "putting on" the stranger he becomes for the duration of the performance. The character thus produced inhabits the interface between actor and audience, mediating in the co-production of the theater experience as a form of hospitality between strangers. Characters have, in this sense, a virtual existence through actors and audiences as their living mediums without being possessed by either. Realized in the performance, staged or imagined, this experience of "intersubjective communication" blurs the roles of actors and audiences, actors being, after all, also readers of the plays they enact and audiences to each other's performances, and audiences as readers and spectators are also performers through their imaginative participation. In each co-productive interface, then, theater's messianic power lies ultimately in the play's ability to energize actors and audience, and the latter's ability to experience the strangeness of characters as a call to hospitality.

The idiom of "putting off" and "putting on" persons shared by writers for and against theater has a theological reference in the New Testament, especially in Paul's letters. Whereas in Galatians 3:27 the faithful "have put on Christ" at baptism, Paul exhorts them to "put on Christ" as an ongoing practice, imitating Christ as a way of life. The implied clothing metaphor mediates an inner transformation in which "putting off the old man," the flesh that inclines to sin, is prerequisite for "putting on the new man," the Christian self. ${ }^{50}$ While Paul's repeated exhortations suggest that putting off the sinful flesh is neither an easy nor a decisive transformation, supporters of theater emphasize the moral efficacy of skillful personation. To resume Heywood's comment: "so bewitching a thing is lively and well spirited action, that it hath power to new mold the hearts of the spectators and fashion them to the shape of any noble attempt." ${ }^{51}$ For writers against theater, however, actors indulge rather than put off their sinful flesh, thereby becoming Satan's instrument corrupting spectators by deception. Thus Stephen Gosson writes in Plays Confuted in Five Actions (1582), citing the authority of church fathers, that "Stage Playes are the doctrine and inuention of the Devuill ... the better thereby to enlarge his dominion and pull vs from God." 52

In Agamben's terms, one can say that the attack on theater aligns with the secular in its use of church authority, mobilizing the logic of demonic possession in a zero-sum battle over souls between church and theater. By contrast, theater is profane in defense of its profession as grounded in a relational practice with audiences that goes beyond possessiveness. While antitheatrical attacks are not matched in number or ferocity by protheatrical defenses, 
Jeffrey Knapp has shown that "a surprising number of writers throughout the English Renaissance depicted plays as godly enterprises." ${ }^{53}$ Such defense is largely indirect, of which plays are a source, among other things poking fun at the stage Puritan who is guilty of the very things he condemns in others. Such profanation is Malvolio who, although "sometimes he is a kind of Puritan," as Maria describes him, nevertheless goes cross-gartered for his lady's pleasure-and ours (2.3.125).

Against the backdrop of the theater debate, we may trace the contours of an ethics of theater as hospitable performance in the characterization of Viola. Donna Hamilton reminds us that "Twelfth Night displays its connection to the issues of religious controversy with a disarming playfulness. The characters do not talk directly about religion and church politics, but religion and church politics often provide the language for what they do talk about." 54 In particular, Maurice Hunt notes that "the devil is mentioned at least twenty times" 55 in the play, notably in association with Viola, including her own soliloquy on Disguise, which she calls "a wickedness, / Wherein the pregnant enemy does much" (2.2.25-26). At issue here, Hunt observes, is theater's transvestite practice, citing Gosson who finds deplorable "in stage plays for a boy to put on the attire, the gesture, the passions of a woman." In calling Disguise to account, Viola would seem to adopt the antitheatrical position, but Cesario, the name she chooses for her disguise, suggests otherwise, especially in light of two cultural associations.

The first association is Christ's counsel to his disciples to "giue to Cesar the things that are Cesars, and to God those that are Gods" (Mark 12:17). Putting on a theatrical person does not entail possession by the pregnant enemy; rather, Cesario provides the cover behind which Viola remains in but not of the world, a stranger to secular ways. Cesario thus marks Viola's messianic potential as an inner resistance to the possessive logic that defines "the things that are Cesars," a resistance built into Shakespearean theater's comic negotiation of the secular order that remains attuned to the emancipatory (messianic) potential of religious themes. The second association suggests Caesarean birth, a medical procedure traced to imperial Rome. In this relation, Cesario's substitute prematurity enables Viola not to "be delivered to the world, / Till I had made my occasion mellow, / What my estate is" (1.2.37-39). Here Christian identity finds its bearings in messianic time: in anticipating her own unveiling, Viola must both wait and be ready when occasion ripens to put off her worldly disguise. That Viola should be unveiled before she can put off Cesario's clothes suggests that her timing is overtaken by that of the marriage plot. Nor is it accidental that Malvolio, the bearer of ill will should hold the key to the prison that holds the keeper of her "maid's garments" (5.1.268). This last-minute revelation by Viola unveils Malvolio's connection to secular authority in its extreme inhospitality, the prison as the secular order's ultimate hold on her-and theater's-messianic potential. 
From a metatheatrical perspective, being "unveiled" in disguise makes Viola the poster-child for Shakespeare's apology for actors. As a character caught acting, Viola exemplifies "the early dramatic figuration of an actorcharacter" which, Robert Weimann explains, "thrived on a doubleness in (im)personation." 56 As Weimann further notes, what the actor-character does onstage "is the most basic, ordinary task in the profession of the actor," and is often done "in support of the play's larger issues." 57 In Twelfth Night, beyond her part in presenting hospitality as an issue, Viola also performatively extends theater's hospitality to the audience. From her first appearance, she has functioned to draw audience members into the play. They enter Illyrian society with her, and like her, as strangers. They witness her decision to put on disguise, reappearing as Cesario. Their alignment with her allows them a perspective on the play's world that is at once involved yet distanced, filtered through the "bi-fold gestus in the actor-character involving both the personater and the personated." 58 They are privy to her self-presentation as a "eunuch" who "can sing / And speak ... in many sorts of music" (1.2.52, 53-54), couching the actor's skill in neutered flesh and the versatility of an instrument through which the human voice sounds in materializing individuated theatrical persons (cf. the Latin personare, to sound through). ${ }^{59}$ They note her worldly act when Cesario pays for access to Olivia. They see wisdom in Feste's cynical wit through her eyes when Cesario remarks, "this is a practice / As full of labor as a wise man's art" (3.1.58-59).

Through her role as actor-character, Viola renders an account of theater's hospitality within a fictive account of Illyrian household inhospitality, and at both levels Twelfth Night professes a performative ethics that is always open to profane epiphanies_yet, skirting ever so closely the "apparatuses" of a nascent capitalism. As Agamben argues, "capitalism is nothing but a gigantic apparatus for capturing ... profanatory behaviors," ${ }^{60}$ to which theater also remains open and vulnerable. In Viola's unveiling, the play leaves to the hospitality of the audience's imagination whether atonement would be possible with the "notoriously abused" Malvolio (5.1.366), or redemption for Feste, the figure of commercial theater, that self-professed pander who demands payment at the gate.

\section{Notes}

I would like to thank the editors or the present volume and the participants of the Shakespeare Association of America 2013 "Shakespeare and Hospitality" seminar for their hospitable engagements with earlier versions of this essay.

1. All quotations of Shakespeare's plays are taken from The Norton Shakespeare, based of the Oxford Edition, ed. Stephen Gleenblatt et al. (New York: Norton, 1997).

2. This term appears in Lisak's essay, "Domesticating Strangeness in Twelfth Night," Twelfth Night: New Critical Essays, ed. James Schiffer (Abingdon, Oxford: Routledge, 2011), 167-83. 
3. Felicity Heal, Hospitality in Early Modern England (Oxford: Clarendon Press, 1990), 9.

4. Lisak, "Domesticating Strangeness," 172.

5. Whether or not the title may be an afterthought, an addition made to differentiate this play from a previous one titled What You Will is not at issue here, since even as an afterthought, the addition of Twelfth Night only helps to bring out what is latent in the text.

6. Tracy McNulty, The Hostess: Hospitality, Femininity, and the Expropriation of Identity (Minneapolis: University of Minnesota Press, 2007).

7. Ibid., xxvii.

8. Ibid., xxxvii.

9. Ad Putter, Sir Gawain and the Green Knight and French Arthurian Romance (Oxford: Oxford University Press, 1995), 52.

10. Catherine Brown Tkacz, "Susanna Victrix, Christus Victor: Lenten Sermons, Typology, and the Lectionar," Speculum Sermonis: Interdiscplinary Reflections on the Medieval Sermon, ed. Georgianna Donavin, Cary J. Nederman, and Richard Utz (Turnhout: Brepols Publishers, 2004), 56.

11. Lynn Staley, "Susanna's Voice" in Sacred and Profane in Chaucer and Late Medieval Literature: Essays in Honour of John V. Fleming, ed. Robert Epstein and Will Robins (Toronto: University of Toronto Press, 2010), 46.

12. David Lyle Jeffrey, "False Witness and the Just Use of Evidence in the Wycliffite Pistel of Swete Susan" in The Judgment of Susanna: Authority and Witness, ed. Ellen Spolsky (Atlanta, GA: Scholars Press, 1996), 59-60.

13. Lindsay Kaplan, "Sexual Slander and the Politics of the Erotic in Garter's Susanna" in The Judgment of Susanna: Authority and Witness, ed. Ellen Spolsky (Atlanta, GA: Scholars Press, 1996), 73.

14. Tessa Watt, Cheap Print and Popular Piety, 1550-1640 (Cambridge: Cambridge University Press, 1991). In Watt's view, the wall paintings “illustrate the fusion of various cultural strands: the Protestant impetus for popularization of the scriptures, the iconophobic tendency to avoid the more sacred figures of Christianity and the traditional demand for narrative" (203; quoted in Kaplan, 73).

15. Ibid., 119.

16. The line-filler refrain "lady, lady" disappears in the stanzas 16-18, which narrate Daniel's intervention. The ballad "was licensed in 1562-63, although the known version is based on the earliest print, which dates from ca. 1625" (Ross W. Duffin, Shakespeare's Songbook [New York: Norton, 2004], 27).

17. The Geneva Bible. Facsimile of the 1560 edition (Madison: University of Wisconsin Press, 1969). All biblical references are from this edition unless otherwise noted.

18. Naseeb Shaheen, Biblical References in Shakespeare's Plays (Newark: University of Delaware Press, 1999), 236-37.

19. Jeffrey, "False Witness," 61.

20. Walter A. Elwell and Philip W. Comfort, ed., Tyndale Bible Dictionary (Wheaton, IL: Tyndale House Publishers, 1992), 349.

21. The Catholic bishop John Fisher in 1535 invoked Susanna in A Spiritual Consolation written ... to bys sister Elizabeth, as did the Lollard treatise The Testimony of William Thorpe (1407), reprinted in all editions of Foxe's Acts and Monuments; Nicholas Ridley likewise, in speaking out against injustice, and Sir Walter Raleigh, in his own defense (Staley 54-59). 
22. Staley, "Susanna's Voice," 50.

23. Robin Briggs, Witches \& Neighbors: The Social and Cultural Context of European Witchcraft (London: HarperCollins, 1996), 80, 389.

24. McNulty, The Hostess, xlii.

25. Dympna Callaghan, "And all is semblative a woman's part': Body Politics in Twelfth Night," Textual Practice 7, no. 3 (1993): 428-52, 58.

26. Ibid.

27. McNulty, The Hostess, xviii (crediting Heidegger).

28. Judith Butler and Athena Athanasiou, Dispossession: The Performative in the Political (Cambridge: Polity Press, 2013), 7.

29. Ibid., 7; ix.

30. Ibid., 120.

31. Michel Foucault, "Nietzsche, History, Genealogy" in Aesthetics, Method, and Epistemology: Essential Works of Foucault 1954-1984, vol. 2, trans. Robert Hurley et al., ed. James D. Faubion (New York: New Press, 1994), 369-92.

32. McNulty, The Hostess, xxv.

33. My analysis of Feste's song assumes a degree of integration with the play that goes beyond normal practice in early modern theater. That Shakespeare may have written the words for this song rather than inserting a ready-made one could account for this integration (Duffin 449; Tiffany Stern, Documents of Performance in Early Modern England [Cambridge: Cambridge University Press, 2009], 147). Stern, with whom I agree, sees the song as "providing reflective commentary on the play" (166).

34. Feste may be singing about the man who regrets marrying because (1) swaggering does not compensate for cuckoldry; or (2) bragging leads to sexual betrayal (a topos that recurs in The Rape of Lucrece and Cymbeline). The line may also be read as the hapless man full of swagger yet unable to get a wife, unlike Petruchio in The Taming of the Shrew, who has come "to wive and thrive," and succeeds in both (1.2.53).

35. Giorgio Agamben, The Time That Remains: A Commentary on the Letter to the Romans, trans. Patricia Dailey (Stanford: Stanford University Press, 2005), 22, 26.

36. Ibid., 76.

37. Ibid., 145.

38. Giorgio Agamben, Profanations, trans. Jeff Fort (New Work: Zone Books, 2007), 85, 86.

39. Julia Reinhard Lupton, Thinking with Shakespeare: Essays on Politics and Life (Chicago: University of Chicago Press, 2011), 238.

40. As judicial victim, Susanna came under the same two-witness method by which "Jesus, and others had been found guilty without any cross-examination" (Ellwell and Comfort, 349). Guiltless and falsely accused, she "prefigures Christ in his Passion"; in her vindication "Susanna as victrix" prefigures the resurrected "Christ as victor" (Tkacz 55, 57).

41. Walter Benjamin, Selected Writings, vol. 4, eds. Howard Eiland and Michael W. Jennings. (Cambridge, MA: Belknap Press, 2002-2003), 387.

42. Paul Yachnin and Jessica Slights argue that "character is the organizing principle of Shakespeare's plays" and that "Shakespeare tends to overturn the Aristotelian ranking of plot and character" (in Shakespeare and Character: Theory, History, Performance, and Theatrical Persons, ed. Paul and Jessica Slights [New York: Palgrave Macmillan, 2009], 6, 7). 
43. We learn from both Antonio and Orsino that three months have passed between the first and fifth acts $(5.1 .88 ; 93)$, and we infer that only several hours elapse between the clock striking in act 3, scene 1 and the play's end, so the first two acts take up the bulk of the three months. At the end of act 3, scene 1 Olivia begins pursuing Cesario in earnest. Two scenes later, Sebastian goes sightseeing with Antonio's money, promising to return within an hour. By act 4, scene 1 Sebastian has met Olivia, and they marry two scenes later. At the beginning of the final scene, the priest confirms that the two exchanged vows 2 hours earlier; discoveries then follow, and Malvolio exits.

44. Andrew Gurr, The Shakespearean Stage 1574-1642, 3rd ed. (Cambridge: Cambridge University Press, 1992), 99-100; also quoted in Louis Montrose, The Purpose of Playing: Shakespeare and the Cultural Politics of the Elizabethan Theatre (Chicago: University of Chicago Press, 1996), 91.

45. Montrose, The Purpose of Playing, 92.

46. Quoted in Montrose, The Purpose of Playing, 38; emphasis mine.

47. Thomas Heywood, An Apology for Actors (1612) (New York: Scholars' Facsimiles \& Reprints, 1941), B4r; emphasis mine.

48. This is Yachnin and Slights's summary phrase for Leanore Lieblein's argument in their coedited volume (Paul Edward Yachnin and Jessica Slights, ed., Shakespeare and Character: Theory, History, Performance, and Theatrical Persons [Basingstoke: Palgrave Macmillan, 2009], 177-35). For Lieblein's excellent discussion of Heywood's Apology see Shakespeare and Character, 123-25 and 129-30.

49. Glynn Wickham et al., ed., English Professional Theatre, 1530-1660 (Cambridge: Cambridge University Press, 2000), 179; Helen Ostovich et al., ed., Locating the Queen's Men, 1583-1603: Material Practices and Conditions of Playing (Surrey: Ashgate, 2009), 11.

50. See, for example, Romans 13:11-14; Colossians 3:8-12.

51. Heywood, An Apology, B4r.

52. William Carew Hazlitt, ed., The English drama and stage under the Tudor and Stuart princes, 1543-1664 (New York: Burt Franklin, 1964), 171.

53. Jeffrey Knapp, Shakespeare's Tribe: Church, Nation, and Theatre in Renaissance England (Chicago: University of Chicago Press, 2002), 2.

54. Donna Hamilton, Shakespeare and the Politics of Protestant England (Lexington: University of Kentucky Press, 1992), 82.

55. Maurice Hunt, "Shakespeare's Twelfth Night and 'The Pregnant Enemy': The Devil in What You Will," Upstart Crow 30 (2011): 5.

56. Robert Weimann, “The Actor-Character in 'Secretly Open' Action: Doubly Encoded Personation on Shakespeare's Stage," in Shakespeare and Character: Theory, History, Performance, and Theatrical Persons, ed. Paul Edward Yachnin and Jessica Slights (Basingstoke: Palgrave Macmillan, 2009), 178.

57. Ibid., 185.

58. Ibid., 179.

59. As Patricia Parker points out, the "eunuch" is an early modern name for an instrument that makes no sound of its own, but "is able like no other instrument to 'imitate the human voice' ... while amplifying it and adding something 'new"” (Parker, "Twelfth Night: Editing Puzzles and Eunuchs of All Kinds," Twelfth Night: New Critical Essays, ed. James Schiffer [Abingdon, Oxford: Routledge, 2011], 56-57).

60. Agamben, Profanations, 87. 


\title{
11 Thinking Hospitably with Timon of Athens
}

\section{Toward an Ethics of Stewardship}

\author{
Michael Noschka
}

All too often, to think about hospitality is to become affronted by the inhospitable. According to Marx's famous reading, inhospitality in Timon of Athens is brought into effect by gold, what he defines as "the alienated ability of mankind" and what Timon rebukes as humanity's "common whore ... that puts odds / Among the rout of nations" (4.3.43-44). ${ }^{1}$ Recent stagings channel such Marxist anxieties. The National Theatre's internationally broadcast 2012 production, for example, has been hailed as "a parable of the crisis of the modern business elite." I would suggest, however, that the anxieties levied within Timon in both its contemporary and early modern stagings go deeper than Marxism and our own fiscal anxiety alone can gloss. As G. Wilson Knight writes, Timon of Athens "is far more than an economic extravaganza." ${ }^{3}$ If it is not the specter of the Market, then what in Timon do we continue to find so haunting?

Derrida turns to Shakespeare to create a word, hauntology, and like Hamlet's Ghost (or Marx's specter), I would propose that a spirit haunts Timon. ${ }^{4}$ This spirit, I suggest, is a call for hospitality in its biblical sense, which is at once material and spiritually invoked. From a theological perspective, the material care for another's physical well-being (food, drink, clothing, shelter, etc.) is rooted in the spiritual mandate "thou shalt love thy neighbor as thyself." This neighbor love is the practice of agape, the self-denying biblical concern for the other. Between roughly the 1580s and 1630s there was a revival in the understanding of Christian charity as agape in early modern England; concomitant was the discussion in sermons and conduct literature regarding the degree to which agape's practice (or, indeed, its deficit) belonged to the cultural understanding of both stewardship and hospitality. ${ }^{5}$ To read Timon, I argue, is to experience hospitality's failure as a material practice alone and to witness the inhospitality of the exclusively material. In Timon, Shakespeare treats both hospitality's imminent death and its possible (immanent) resurrection through acts of stewardship funded by agape.

Although it may seem "odd perhaps to consider Timon of Athens a religious play," as Julia Reinhard Lupton reminds, "the word religion recurs three times in Timon, more than in any other play by Shakespeare." 6 Thomas Carter's influential work on the subject of Shakespeare and the Bible finds 
no less than thirty-five references in Timon, indicating a deep scriptural archive underwriting this play. ${ }^{7}$ In a similar vein, both Knight and James Bulman have called attention to the play's likeness to a parable. ${ }^{8}$ Shakespeare approaches Timon not as parable or allegory but rather as a script of lived action, one that resonates across the Hebrew and Christian Bibles in what Lupton has called Timon's "greekjew world," or what Daniel Boyarin describes as the "Hellenistic Jewish cultural koine" of the Mediterranean in the first-century Near East. ${ }^{9}$ The script of hospitality I track across Shakespeare's Athens and its outer wilds draws deeply upon two specific parables. Shakespeare introduces Timon through direct allusion to the parable of the Five Talents, a story espousing an ethics of stewardship. Similarly, in his self-sacrificing care for Timon, Flavius, the play's exemplary steward, enacts the model of hospitality recounted in the parable of the Good Samaritan. Both of these parables, in turn, comport as agape in their call for material and spiritual succor. Taking up this agapeic turn, Shakespeare seems to ask his audiences both then and now, through this particular Athens and the actions of these particular Athenians, to consider the very real possibility of hospitality as stewardship.

My argument is concerned not with tracking typologies but with disclosing models of behavior. For Derrida, hospitality defined through any act of gift giving is impossible because such an act is always already caught up within an inescapable system of exchange that both expects and demands reciprocity. In Derridean terms, "there is no gift in gift exchange; there is only exchange." 10 This essay shifts attention away from reading Timon in terms of an economic model of exchange in order to attend to Shakespeare's representation of relational dwelling and its failures within the oikos. While it is true that oikos serves as the root for our modern (and early modern) economy, in order to move beyond this economic circuit of thinking I here use the term in a phenomenological sense of lived and shared proximity to and existence with others.

The terms I wish to use-dwelling, oikos, hospitality as stewardshipcan be defined properly only in the process, but some prefatory discussion is helpful. I use dwelling in its Heideggerian sense and as the Hebraic yashab. Dwelling is a neighborly nearness; it is the state of being in proximal relationship to and with others, with the express desire to secure an other's care, safety, and flourishing. ${ }^{11}$ In what follows I use the term oikos to mark the space for dwelling as person, home, and wider community. The degree to which oikos denotes "home" or even "community" likely needs no further gloss, but the person as oikos is a concept that may require more explanation. I use the term here in the sense of dwelling, or rather in-dwelling, as in the in-dwelling of the spirit-the Greek pneuma and its Hebrew counterpart ruach - the divine life force of biblical tradition that animates humans exclusively and is distinguished from soul (nephesh), the aspect the human shares with the animal in their collective creaturely estate. ${ }^{12}$ Biblical stewardship, the relational care of and for others, is a form of giving like 
tithing, but with a caveat: stewardship is a giving back of what is not truly one's own to begin with, but rather of what one has been given by God. Biblical stewardship enters Western thought through the Genesis narrative, which reports mankind's first vocation as the caring for all creaturely life. ${ }^{13}$ Genesis also narrates stewardship's first encounter with the inhospitable. The story of Cain and Abel narrates the first acts of tithing and murder, yoking the two together in a correlation to which Timon returns at its conclusion with Alcibiades's acceptance of a tenth of Athenian lives in lieu of full-scale invasion $(5.5 .31-35,54-58)$. Cain's query to God- "Am I my brother's keeper?"-is answered time and again across the Hebrew and Christian Bibles: Yes, you are. ${ }^{14}$

My reading of Timon seeks to shift critical attention away from gift exchange, biblical or otherwise, in order to better attend to hospitality in its vocation as stewardship, a mode that offers not only an alternative economics (oikos-pneumatics) but one that also better services the alterior, a term of philosophical shorthand used to designate the other in his or her alienating exteriority or estate as a lower class of being (subaltern). ${ }^{15} \mathrm{My}$ ulterior motives-that is, my concern with an ethics of and for the other-follow Timon's necessarily spiritual tack to the degree that within this particular Athenian locale Shakespeare gives us pause to consider hospitality beyond a wholly material register; that is, beyond a system of inescapable exchange and the aporia of Derrida's impossible gift. After giving a brief overview of hospitality and stewardship in early modern England, I turn attention to Timon as a script for lived action, first by reading Timon in the context of the parable of Five Talents and then by turning to his steward Flavius in conjunction with the parable of the Good Samaritan and its call for hospitality as an other-servicing dwelling-with.

\section{Oikos-Pneumatics}

Felicity Heal has uncovered a vast archive of early modern English hospitality literature written between the 1580 s and 1630 s. ${ }^{16}$ Sermons and conduct literature figure prominently in this discussion, as does social commentary. Heal attests that "for most authors revealed religion, and especially the New Testament, provided the fundamental injunctions enjoining a householder to be hospitable," often citing Matthew 25:35-36, Romans 12:13, and Hebrews 13:2 as hospitality's spiritual proof texts. ${ }^{17}$ Although "scripture provided the most powerful spur to hospitable behaviour," as Heal reminds, the Greek and Latinate thinking of Aristotle, Cicero, and Seneca each "provided analyses of generous behaviour that were peculiarly pertinent to the host." 18 Timon, believed to be written between 1604 and 1606 and printed in the First Folio of 1623, correlates with Heal's archival "chorus of lamentation" drafted to address the perceived decline in the proper practice of hospitality in early modern England. ${ }^{19}$ Whether by scriptural or secular precedent, it was a commonly held opinion that nobility especially and gentility as well were called to be good hosts. Thus Clement Ellis writes 
typologically of the Englishman's estate in The Gentile Sinner; or, England's Brave Gentlemen (1660) that the nobleman or gentry is expected to keep "Hospitality his Housekeeper, Providence his Steward, Charity his Treasurer." ${ }^{20}$ Ellis' typological associations encode the spiritual understanding of hospitality in the period that I will be tracing through Shakespeare's Athens.

Hospitality as housekeeper marks the domestic arts of household management. Yet when the oikos is considered as a site of domesticity (home) as well as of selfhood relative to the in-dwelling of the spirit, the practice of hospitality bears a decidedly spiritual aspect, a practice of immanence requiring service to and for others: proper housekeeping in deed. The steward in Ellis's typology is providence, a term signifying both prudence and the prudent management of one's resources (actions befitting a steward), as well as a scriptural bearing in the Pauline sense of God's grace given providentially to guide the course and direction of a believer's life. Charity, the Christian practice of agape, a self-sacrificing and other-servicing love, funds the treasury of Ellis' typology of hospitality.

In the more modern sense of stewardship as an economic vocation, the steward's primary role was the management of his lord's estate. In this comportment the steward was effectively an ambassador, "serving as his master's voice, as well as his eyes and ears," speaking on the lord's behalf to tenants, craftsmen, nobles, lawyers, or magistrates. ${ }^{21}$ The steward's vocation required him to be equally adept at navigating social interactions among the lower and upper classes alike with the full weight of his master's authority. It is in this capacity that D. R. Hainsworth has described the steward as "a 'mediator' in the anthropological sense of the word." 22 And while it is true that the steward was tasked with meeting all expenses of estate income, including the taking in of "rents, fines and dues and transmitting that money to London," this role, even in its ostensibly secular turn, continued to bear a spiritual charge. ${ }^{23}$ That is, estate management (stewardship) was also recognized during the period to be the vocational calling of all humankind laid out in the Bible.

Under this paradigm, whether highborn or low, all were called to the service of others. It is in this vein that critics have referred Flavius to a biblical manner of stewardship. Maurice Hunt, for example, sees the character of Flavius as Shakespeare's attempt "to recapture an ideal image of the steward," one who "comes closest to expressing a cardinal principle of Christianity." 24 We see charity given its cardinal direction, to borrow Hunt's phrasing, in the marginal notes for 1 Peter 4:8 in the Geneva Bible:

Of all the duties of charity, he [God] commendeth one, namely, which was at that time most necessary, to wit, hospitality, which he will have to be voluntary and most courteous and bountiful. He showeth the use of charity, to wit, that every man bestow that gift which he hath received to the profit of his neighbor. A reason, because that what gift soever we have we have received it of God upon this condition, to be his disposers and stewards. ${ }^{25}$ 
Per the Geneva's annotations, biblical stewardship is understood as the management of funds from on high as gifts entrusted by God whose expenditure is expected to profit one's neighbor. In its original Greek, what the King James Version translates twice as charity in v.8, is literally love (agapen and agape, $)$, thus conceiving hospitality as stewardship and operant under the banner of agape. ${ }^{26}$ Hospitality funded by agape is a premise central to the parables of the Five Talents and Good Samaritan, particularly as they are conscripted by Shakespeare in the drafting of his Athens and its outer environs.

In Timon's domestic sphere Shakespeare would seem to take up an advocacy for the praxis of agape demonstrated most readily by Timon's failures and Flavius's actions, that is, through their respective acts of stewardship. The scholar and Jacobean Biblical translator John Bois encapsulates the early modern English theological understanding of stewardship:

All of vs then are stewards, and disposers of some goods of God: Clergie men are stewards of Gods house, which is the Church; all Magistrates are stewards of the common house, which is the weale publike; Masters are stewards of their own priuate houses; al men are stewards and clerks of the priuie closet of their conscience. There is none so mighty that is greater or so meane that is lesse than a steward to the King of Kings. ${ }^{27}$

In Bois's formulation one finds an understanding of stewardship's alternate economics as oikos-pneumatics, a spiritual economy under whose management are the overlapping oikoi of the individual, home, and community or state. This alternate economics is funded by agape that takes as its management the care and well-being of others. I here use the term funded in the sense of the Latin fundus, as a building ground or site of foundation. Agape in its comportment as hospitality has been recently taken up by Caron Gentry who argues that hospitality in its acknowledgement of "the deep responsibility the self has for others" is, in effect, agape. ${ }^{28}$ As a contemporary of Shakespeare's, clergyman Thomas Adams demonstrates this understanding of agape in the call for his parishioners (and the readers of his sermon) to "[w]alke in Loue" by enacting hospitality. ${ }^{29}$ As Adams enjoins,

He [St. Paul] doth not say, talke of it, but walke in it. This precept is for course, not discourse. Loue sittes at the doore of many mens lips, but hath no dwelling in the heart. We may say truely of that charitie; it is not at home. ${ }^{30}$

In an equally Pauline turn, Shakespeare scripts Timon's actions and associations through the overlapping language of home, dwelling, and charity. In short, hospitality as lived agapeic action, what Adams describes as walking in love. 


\section{(Im)material Hospitality}

Shakespeare, I propose, invites us through his Athenian tragedy to consider the possibility of an alternate economics (oikos-pneumatics) whose currency is love and whose concern is its proper management. Even if one subscribes to the paradigm of hospitality as gift-exchange, it nevertheless remains that Shakespeare writes of Timon's giving in a decidedly biblical mode. His first appearance on stage is in conversation with Ventidius's messenger who pleads on his master's behalf for Timon to pay the noble's five talent debt. As if to signal exchange, the messenger responds to Timon's pledge of surety, "Your lordship ever binds him" (1.1.106). Yet Timon's rejoinder confirms no expectation of reciprocity as yet; in fact, it speaks of quite the opposite. In a Torahic gesture reminiscent of the call to care for widows, orphans, the lame, and poor, ${ }^{31}$ Timon enjoins the messenger:

Commend me to him. I will send his ransom;

And, being enfranchised, bid him come to me.

'Tis not enough to help the feeble up,

But to support him after.

The koine of Timon's response recalls both the Hebraic yashab and Christian stewardship. Despite its initial fiscal gesture in paying the ransom, Timon's express concern is to "support" his enfeebled friend. Relative to yashab we might consider such support as a spiritual-architectural propping up, a "support" for dwelling intimated by Timon's desire conveyed to the messenger, "bid him come to me." By his own account, proximity (yashab) is at the center of Timon's action. True to the Hellenistic Jewish composite of Shakespeare's Athens, Timon's response also marks an act of Christian stewardship, dispensing the wealth in his charge (whose Hellenized koine and material coin are equally funded by agape) for the good of others, in this case Ventidius's release from bondage.

The specific monetary amount owed by Ventidius overtly recalls the parable of the Five Talents. ${ }^{32}$ The story tells of a master who before going on a journey divides his wealth among three servants, "every man according to his several ability." ${ }^{33}$ Upon the master's return, the first and second servants have doubled the value of that with which they were entrusted. Hearing of their gain, the master famously replies: "Well done, thou good and faithful servant: thou hast been faithful over a few things, I will make thee ruler over many things." ${ }^{34}$ Unlike his peers, the third servant digs a hole in the earth and hides his money in an act that reverses Timon's digging in the wilderness outside Athens' walls. When the master questions the final servant and learns that he has not cultivated his investment, the servant is stripped of his status and the parable delivers its warning: "For unto every one that hath shall be given, and he shall have abundance: but from him that hath not shall be taken away even that which he hath." 35 
As a script for lived action, there is much in this parable that bears exegesis, in terms of both scriptural intent and Shakespeare's development of scripture in Timon's Athens. First is the matter of Ventidius's five talent debt and its subsequent payment by Timon; this sum in its original historical context is exorbitant. A talent in the Greco-Roman world of the first-century A.D. was the measurement of roughly twenty years' wages for a common laborer. ${ }^{36}$ Whether in its Shakespearean or scriptural purview such wealth is staggering.

Biblical scholar Arland Hultgren has suggested that Jesus casts his parable as the management of such near otherworldly wealth in order to convey the duty and risk involved in spiritually funded stewardship. ${ }^{37}$ The first two servants who double the value of the talents entrusted to them by their master do so specifically by engaging in business, ${ }^{38}$ yielding return on their master's deposit only by risking the loss of the respective talents entrusted to them and through the hard work of those talents' cultivation. Returning to the original Greek of the parable, Hultgren confirms " $[t]$ hat the two may have simply made wise investments is ruled out by what is said to the third slave at 25:27." 39 Thus the parable's fiduciary fecundity demonstrates its achievement not by matter of investment but by manner of work that requires risk, a hazard the third servant is unwilling to take (hence his action of burying his apportioned talent until the master's return). In the parable's Shakespearean expression there is similarly no sense of work but merely ready (albeit dwindling) money relative to Timon. In effect, Timon might as well have buried his wealth in the ground; the negative return on investment is essentially the same. As a script of lived action, Timon also enacts no true sense of stewardship in its Christian vocation but rather demonstrates prodigality, a point to which I will shortly return.

With its double repetition of "[w]ell done, thou good and faithful servant" and its caution against poor management, the parable of Talents speaks directly of stewardship. Jesus's point exhibits concern for spiritual return on (God's) investment; that is, the development of one's "talents" for an invested return in the lives of others. The message of the parable is therefore not to increase monetary wealth but the number of lives touched by the Gospel's good news. ${ }^{40}$ It expresses concern for the stewardship of people. The parable of the Five Talents concerns the use of one's "talents" for the growth of the Church through the giving of one's life (one's special abilities or talents) to others out of the economic (oiko-pneumatic) inheritance funded by and through agape per the injunction given in the Great Commandment: Thou shalt love thy neighbor as thyself..$^{41}$

Shakespeare intimately connects Timon with the Five Talents by bookending his character with allusions to this parable. Timon's first entry onto the stage in act 1 is a direct scriptural gesture through his payment of a five talent debt (ostensibly an act of neighbor love). His latter connection is a matter of lexical historiography: reminiscent of the third servant's poor banking methods, Timon finds a wealth of buried "talents" (a mark of unfaithful service) in the Athenian wilds of Act Four. ${ }^{42}$ Unlike the ethics of the parable, however, Timon's management of his talents yields an inverse 
of return. Rather than the ostensible neighbor love of Timon philanthropos, act 3 culminates with his tragic spiral into misanthropy and complete disdain for the entire human race, duly noted by his terse declamation, "Henceforth hated be / Of Timon man and all humanity" (3.7.96-97) and the even more emphatic, "I am Misanthropos, and hate mankind" (4.3.52).

Despite this tragic shift, Timon's initial actions on the stage (and page) nevertheless bear the carriage of seemingly genuine charity. We should remember that his first two actions are to pay for Ventidius's release from prison and to raise his servingman Lucilius to equal marriageable (i.e., economic) weight with the Old Athenian's daughter. ${ }^{43}$ Scholars, however, remain divided on this point. Reading Timon's actions with a more cynical eye, Grace Tiffany has argued that "Timon's apparent magnanimity" is nothing but "an investment without collateral, an ancient Ponzi scheme." ${ }^{44}$ L. C. Knights maintains that "it is not moral truth we recognize but self-indulgence in easy emotion" in Timon's generous gestures. ${ }^{45}$ Yet the initial exchange between Timon and Ventidius in act 1 , scene 2 suggests otherwise.

Ventidius's first words report an inclination toward repayment. "I do return those talents," he tells Timon, "Doubled with thanks and service, from whose help / I derived liberty" (1.2.5-7). In parable-echoing language, Ventidius would double the return of Timon's five talent trust. Shakespeare, however, offers a clever caveat in Ventidius's elocution: what is doubled is not the monetary sum but rather "thanks and service" for his "derived liberty," bringing to mind the aspect of the steward as oikonomos, one released from bondage under the law. ${ }^{46}$ As if speaking the same language of stewardship, Timon, it would seem, interprets his answer and its action as that of dutiful hospitality, rejecting Ventidius' offer of remuneration:

O, by no means,

Honest Ventidius. You do mistake my love.

I gave it freely ever, and there's none

Can truly say he gives if he receives.

If our betters play at that game, we must not dare

To imitate them.

Unfortunately, Timon will indeed imitate those bettors who play at the game of reciprocity (equal or greater return on investment). By the close of act 2 he dispatches servants "severally" to Lucius, Lucullus, and Sempronius requesting a return of fifty talents from each (2.2.181-187), and to the Athenian Senators he sues for an excessive one thousand talents (2.2.190-193). This desire (need) for reciprocal return or its excess serves as a measure of Timon's poor and indeed conflicted understanding of stewardship. At this moment, however, his account to Ventidius directs attention to mistaken "love." I would posit that here Timon implicitly calls to mind agape as a hospitality of relational dwelling in "support" of a friend in need. 
When next Timon acknowledges to those gathered around his table that "We are born to do benefits" (1.2.95), he tacitly invokes 1Peter 4:9-10. According to Ken Jackson, "No character pushes down through Christianity to its desire for the 'other and ... utterly other' in a way Timon does, forcing us to consider where that response and responsibility to 'give' comes from." ${ }^{47}$ For Emmanuel Lévinas, the desire for the other espoused in the Gospels is "already read" in the prophet Isaiah. ${ }^{48}$ I would suggest that Timon's responsibility to give comes from the nuanced distinction in the period between Christian and secular liberality, the former funded by agape and the latter by the desire for reciprocity.

The Renaissance idea of inner beauty manifested by outward appearance extended to the conceptualization of liberal hospitality. "The idea of an indissoluble link between gentility and household generosity," Heal writes, "was here reinforced by an argument that liberality was the particular prerogative of gentlemen and one of the most visible manifestations of true, that is inner, nobility." ${ }^{49}$ For Shakespeare's contemporary audience, then, it would likely be expected that Timon manifest his nobility through liberal action. In its secular turn, however, such liberal generosity was reserved only for peers or near social equals. That is, liberal hosts expected return on their expenditure. Shakespeare offers a glimpse of such opinion in a passing remark between two Lords concerning Timon's coveted (if unwise) hospitality:

\section{Plutus the god of gold}

Is but his steward; no meed but he repays

Sevenfold above itself; no gift to him

But breeds the giver a return exceeding

All use of quittance.

It is thus that Timon's magnanimity is understood by his peers. To extend hospitality to Timon is to expect to receive "a return exceeding / All use of quittance." His good graces on such summation prove a wise investment, one guaranteeing a return "[s]evenfold above itself."

Counterpoised to such secular understanding of liberality was its Christian practice of freely giving to those in need, with an emphasis given to persons of lower social status. In Nevv Booke of Spirituall Physick for Dyuerse Diseases of the Nobilitie and Gentlemen of Englande (1555), William Turner argued that English hospitality suffered a "dropsye," a socio-spiritual disease in the form of secular liberality. On this same point Thomas Adams writes a parable over a half century later of English hospitality's demise:

A great man had curiously engrauen at the gate of his Pallace, the image of Bountie, or Hospitalitie. The needie Trauellers with ioy spying it, approach thither in hopefull expectation of succour. But still silence or an emptie Eccho answers all their cries and knockes: for 
hospitality may stand at the gate, but there is none in the house ... For Charitie is not at home: onely the shadow without ... giues faire and fruitlesse hopes. ${ }^{50}$

On Adams' account it is the poor and disenfranchised, the "needie Trauellers" of this world, who desperately need receipt of liberal hospitality, not well-apportioned gentlemen and nobles who cannot know the "faire and fruitlesse hopes" suffered by those unfortunates whose "cries and knockes" remain unanswered without their doors. Hospitality as secular liberality is thus, following Adams, an act of idolatry, a mere image of (Christian) hospitality, its "emptie Eccho." As with Adams, for Turner the onus of hospitality falls especially upon the nobility since they have been graced with the burdensome gift of great wealth and the subsequent responsibility to steward it wisely. It is from this perspective that I would read Timon's misplaced hospitality in order to better understand its failure.

The grand hospitality of Timon's initial banquet scene opens as guests rise in ceremony at Timon's entry into the hall. Yet in a gesture that seems at first a gentle reproof, he waves them off:

Ceremony was but devised at first

To set a gloss on faint deeds, hollow welcomes,

Recanting goodness, sorry ere 'tis shown;

But where there is true friendship, there needs none.

Pray sit. More welcome are ye to my fortunes

Than my fortunes to me.

Here Timon reads his guests' collective act of reciprocal hospitality, showing deference to the host through "[c]eremony," as a "hollow welcome." While it is true that Timon does so not do so in censure but graciousness (his point is that true friendship needs no such pomp), his comment nonetheless calls attention to the dissembling nature of their (no doubt social and socialized) response whose intent Shakespeare pens as a desire " $[t]$ o set a gloss on faint deeds."

Tragically, at this point in his own narrative Timon does not realize he is caught up in such a false economy of hospitality. He will realize all but too late that his own hospitality has been coveted and abused by hollow "trencher-friends" who prove themselves to be naught but "detested parasites" and "[c]ourteous destroyers" $(3.7 .88,86,87)$ of his goodwill. The gathered nobles are clever actors at the table and further dissemble by way of an entreaty that continues to "gloss" their "faint deeds":

Might we but have that happiness, my lord, that you would use our hearts, whereby we might express some part of our zeals, we should think ourselves forever perfect. 
This is the secular liberality censured by Turner. As my italicization shows, the nobles' intention is self-gratification, not hospitality's comportment as service to the other. In a Hamlet-esque turn, their speech act is seeming hospitality only. The voiced desire to give something of themselves to be used by Timon reveals instead an expectation of return - even if only by payment in self-aggrandizement ("we should think ourselves for / ever perfect"). That is, they do what custom among peers dictates: you offer to return the hospitality you have received, even if only as an empty rhetorical flourish designed to maintain social appearances.

Timon's response to their entreaty, however, begins to show the cracks in the foundation of his hospitality. " $\mathrm{O}$, no doubt, my good friends, but the gods themselves / Have provided that I shall have much help from you, / How had you been my friends else?" (1.2.84-86). Perhaps subconsciously, Timon here admits that he indeed harbors some expectation of reciprocity ("the gods themselves / Have provided that I shall have much help from you"). His interrogative quip, "How had you been my friends else," no doubt voiced cheerfully and with good-humored charm, further suggests such assumption of use. It is important to note that the poor, homeless, or otherwise abject are not those shown welcome at Timon's table, despite the intent purported otherwise in his hospitable speech to Ventidius' messenger ("'Tis not enough to help the feeble up, / But to support him after" [1.1.109-110]). Rather, those "feeble" gathered to benefit from Timon's hospitality are those who can return the favor-even if they ultimately fail to do so.

It was widely recognized in the period that opposition or hindrances to hospitality as Christian liberality existed in two common forms. As Turner phrases it, "lyberalitie is set betwene .ii. vices, $\mathrm{y}^{\mathrm{t}}$ is, prodigalitie \& couetusnes." 51 Such opinion is confirmed by Gervase Markham whose treatise $A$ bealth to the gentlemanly profession of seruingmen (1598) follows a similar cultural-medical frame with regard to the declining health of English hospitality as Turner's Nevv Booke of Spirituall Physik:

According to thy abilitie mainteyne Hospitalitie: for that is the harbourer of two hopes, prayse, \& prayers: yet let Liberalitie be the Linke to light thee, least Couetousnes might corrupt, or Prodigalitie procure penurie, in medio concistet virtus, enery meane betwixt two extreames, is a vertue: so is liberalitie, betwixt auarice and prodigalitie, being placed: this meane in al musicke yeelds a most heauenly harmonie. ${ }^{52}$

The mean that yields harmony for Turner resonates as discord in Timon, where the preservation of means (available resources, money) trumps hospitable action for everyone but an unwise Timon. The treatise also equates covetousness with avarice, a transaction concomitant with the behavior of Shakespeare's Athenian nobles in their refusal to remit Timon any form of 
financial aid. Lucullus perhaps voices such accounting best: "this is no time to lend money, / especially upon bare friendship without security" (3.1.37-38).

Flavius discerns what Timon does not. In act 2, with creditors closing in, the steward pulls his master aside in a moment of intimate reproach so that he may help Timon understand the gravity of his situation (2.2.159165). On Flavius's report, Timon gluts himself on hollow praises even as his "friends" englut themselves on his bounty (2.2.161). Shakespeare references bounty seven times in relation to Timon throughout the play's course, suggesting its import. Flavius's gesture to the heavens, "'Heavens,' have I said, 'the bounty of this lord!" (2.2.159), even if only in exclamation (or perhaps invocation), advances a divine eye toward Timon's bounty. For Flavius, this bounty is that which has been entrusted to Timon by the gods, or by God in Timon's greekjew parlance. Yet for those of wider Athens, Timon's bounty is reducible to the plea of the prostitutes Phrynia and Timandra: "More counsel with more money, bounteous Timon" (4.3.166). What Timon sees in himself as philanthropic_-"I could deal kingdoms to my friends, / And ne'er be weary" (1.2.215-216) -Flavius reports as "prodigal bits" (2.2.160). Taking up the charge of prodigal, Rolf Soellner accuses Timon of being "one cause of a societal crisis in Athens," on the grounds that "his prodigality supports the corruption and Hobbesian values of the city." 53

During the period, such charges of societal crisis were posed vehemently by conduct literature such as Turner's Spirituall Physick. By Turner's indictment, "Thys commonly vsed liberalite in Englande nowe, is no true liberalite, but rather prodigalitie, for it is quyte contrarie both to ye liberalitie that God describeth and appointeth." ${ }^{54}$ Turner's jeremiad admits a material aspect to hospitality (food, drink, shelter, and clothing) but maintains that such apportioning should come from spiritual precedent. The prophet Isaiah is invoked to remind the elite classes ("all Emperores, kynges, dukes, erles, lordes, knyghtes, gentlemen and al other ryche men") of their overriding vocation as God's stewards on this matter. ${ }^{55}$ Yet " $[\mathrm{t}]$ his commaundement of God," Turner inveighs, "is commonly broken in occupyenge of lyberalitie," that is, in the practice of secular liberality. ${ }^{56}$ Such is Timon's hospitality despite what seem to be his good intentions otherwise. The poor and homeless, those "poore \& wanderyng men, or wayfaring men, or straungers that haue no houses," occupy the center of Turner's argument, ${ }^{57}$ yet we see no poor in Timon except for the servants discharged after the fall of Timon's estate, the two prostitutes accompanying Alcibiades (to whom he shows open contempt), and the eponymous character himself in the play's final two acts.

It is only rich nobles who receive Timon's hospitality, or rather, his prodigality. Moreover, it is from these same noble "friends" that his prodigality expects reciprocity. It is thus that Timon speaks to Flavius of his financial crisis as a type of blessing, "for by these / Shall I try friends" (2.2.177-178). Such trial is the reciprocity expected of hospitality as secular liberality. With 
creditors at the doors even Ventidius is expected to repay the five talents of a debt now reinstated. Flavius is thus dispatched to Ventidius with the following charge:

Greet him from me.

Bid him suppose some good necessity

Touches his friend, which craves to be remembered With those five talents.

Once more, Shakespeare associates Timon with the parable of the Five Talents. It would seem, however, that Timon has here forgotten his own argument for a hospitality funded by agape ("you do mistake my love ...") in his initial dialogue with Ventidius. Perhaps such is the nature of prodigality.

\section{Dwelling-With}

Timon is a play concerned with dwelling, the relational proximity of lived hospitable nearness. However, it is as misanthropos that Timon delivers a final instruction to his steward: "thou shalt build from men" (4.3.5128). This injunction recalls the Decalogue's own "thou shalts," which Lévinas has described as spaces where "[a]lterity becomes proximity." ${ }^{8}$ That is, in the "thou shalt" Lévinas locates an ordinance of the other. Heidegger finds a similar correlation between self/other at the level of neighborliness in his native German bauen, "to build." For Heidegger, there exists in bauen a "covert trace," a lost etymological residue, of Nachbar, "the neighbor." 59 As he puts it: "The Nachbar is the Nachgebur, the Nachgebauer, the neardweller, he who dwells nearby." ${ }^{60}$ Per Heidegger's genealogy, also in-dwelling within bauen is the verb to be.$^{61}$ Dwelling pace Heidegger is an ontological status; to live authentically is to dwell. Contrary to Timon, it is to build (bauen) in nearness to others.

Flavius understands well this comportment of dwelling. On this point John Jowett's reading of Timon's steward bears repeating in full:

he distributes his last money to the servants under his authority, reserving only what he intends to give to Timon. This does not greatly enrich the servants because the money is so little, and the script is written so that the servants express no gratitude beyond the communal embrace shared by giver and receivers alike. ${ }^{62}$

Jowett's description aptly illustrates how Flavius builds in nearness to others. What is built is the "communal embrace," a commune of shared relationality that is simultaneously a religious encounter in its aspect as religare, a site of communal binding and union. If Flavius is "pathologically loyal," to borrow A. D. Nuttall's phrasing, then it is to his vocation as an imitation 
of the life of Christ as a steward. ${ }^{63}$ Hunt reads Flavius in this fashion: "This self-sacrificial spirit [agape], however, seems to live more fully in the steward Flavius, an impression encapsulated for a later age as a Christian truth: 'For the Son of Man came not to be served but to serve, and to give his life a ransom for many' (Mark 10:45)." ${ }^{64}$ It is in answer to the call "not to be served but to serve" that both Jesus and Flavius demonstrate dwelling's spiritual aspect as oikos-pneumatics.

Heidegger constructs his dwelling through a framework he describes as the fourfold. Its elements-earth and sky, divinities and mortals-are conjoined in a matrix of interdependence. For Heidegger, proper dwelling retains an aspect beyond creaturely/material estate, thus the inclusion of a supra/supernatural (or "pneumatic") component (and comportment) in the divinities. This fourfold further comports with the biblical paradigm of stewardship in its vocational calling to "cherish," "protect," "preserve," and "care for" those with which one dwells-whether human, animal, environmental, or thing. ${ }^{65}$

As misanthropos there is arguably none more alterior within or without Athens than Timon, and yet Flavius would dwell with him in genuine care:

That which I show, heaven knows, is merely love,

Duty and zeal to your unmatchèd mind,

Care of your food and living; and, believe it,

My most honoured lord,

For any benefit that points to me,

Either in hope or present, I'd exchange

For this one wish: that you had power and wealth

To requite me by making rich yourself.

The steward's care flows from a love that "heaven knows," one of "[d]uty and zeal;" thus it is a love of conscious and willful moral choice. ${ }^{66}$ In short: agape. Flavius' "one wish," though qualified as exchange, does not concern itself with the transaction of wealth as gold but relational proximity; it is a wish that Timon would be rich in dwelling, the shared nearness of a genuine love for the other. Implicit in Timon's rejoining, "Thou singly honest man, / Here, take"-at which point the stage directions report "[He gives FLAVIUS gold]" (4.3.515-516)—is an echo of the parable of the Talents. One all but hears Timon speak to his once-steward, "Well done my good and faithful servant." ${ }^{67}$ And like the good stewards of the parable, Flavius is entrusted with more (here, gold and the injunction to build away from men) because he has proven himself a wise caretaker. Flavuis' response to Timon's outpouring of wealth- "O, let me stay / And comfort you, my master" (4.3.525-526)— discloses a desire for relational dwelling, even as Timon voices his disdain for all human contact. 
There is perhaps no greater biblical representation of stewardship qua dwelling than the story of the Good Samaritan. In the world of first-century Palestine, when baited by a lawyer on the question of neighbor-love- "And who is my neighbour?"-Jesus answers with this well-known parable. ${ }^{68}$ By its account it is not the outwardly religious (the priest or the Levite) who offers hospitality to the person in need, in this specific case a man left wounded and naked by the roadside in the wake of abuse by highwaymen. It is the foreigner, the stranger, the alien, the alterior-the Samaritan-who offers succor. The narrative tells that it is he who shows "compassion" for his fellow man by dressing his wounds with wine and oil, expensive commodities in those days. The Samaritan then establishes this unknown man at an inn for which he pays all expenses.

Exegesis from the Church Fathers through the early modern period tended to allegorize this parable following the model set forth by Augustine ${ }^{69}$ From this hermeneutic paradigm, the wounded man in need of care is Adam, Jerusalem is the heavenly city, Jericho symbolizes mortality, the good Samaritan is Christ, and so on. ${ }^{70}$ Reformation theologians tended to adopt Luther's disdain for allegorization (he famously derided Origen's allegorizing as being "worth less than dirt") and yet Luther himself nonetheless allegorized the parable in terms of his prevailing interest in sola fide. ${ }^{71}$ Calvin, however, is unique among the Reformers in that his reading of the Good Samaritan rejects the hitherto prevailing Christological interpretation. ${ }^{72}$ Instead, in his A Harmony of the Gospels (1555), Calvin reads the Good Samaritan as a model of hospitality in human-to-human praxis. Upon Calvin's explication Jesus's impress in the parable is "to show that neighbourliness which obliges us to do our duty by each other is not restricted to friends and relations, but open to the whole human race."73 Calvin's reading coincides with Jesus's erasure of the neighbor-enemy dyad in his Sermon on the Mount. Such openness (to use Calvin's word), however, proves risky business.

Like the parable of the Five Talents, the Good Samaritan's association with risk is connected to a cultural understanding of its message. The priest and Levite in the story, for example, are perhaps not as incredulous as they might first seem. Vallet reads the parable as a narrative about taking risks for the sake of others. ${ }^{74}$ In this context he reminds contemporary readers and exegetes alike that both the priest and Levite faced the risk of being unclean for an extended period of time, more if the body they touched was dead, less if they came into proximal relation with an unclean person. ${ }^{75}$ In either case these religious men faced social ostracism prescribed by the law, even if only for a short time, a risk they are unwilling to hazard. Yet in the world of first-century Palestine, the Samaritan faced no less risk than the priest or Levite. As Sylvia Keesmaat has contextualized, Samaritans too followed Torah and thus risked defilement from touching an unclean body. Moreover, as one traveling with the wealth identified by the parable, the Samaritan risked similar attack by robbers on the Jericho road. ${ }^{76}$ What 
differentiates the Samaritan from the holy men in the narrative is his willingness to act in agape, in concern for the other, in loving hospitality, despite the risks involved. Like the Samaritan, Flavius risks no less in carrying gold into the Athenian wilderness to aid Timon. He too is a prime target for bandits, though not from those on the Jericho road but the highwaymen who canvass Athens' woods. Echoing the risks of the priest, Levite, and Samaritan alike, Flavius chances not only loss of wealth and material possessions, but also the potential threat to his well-being. Even so, Flavius would tend to Timon's needs following the script of Christian liberality set forth in parable.

The Samaritan's actions conjoin material hospitality to the spiritual call to care for others. The parable's Greek is also telling. The "compassion" by which the Samaritan is moved is from the verb splagxnizomai, meaning "to be moved in one's inward parts." ${ }^{77}$ A 1578 sermon by John Stockwood confirms that such an understanding of the Greek was recognized in Shakespeare's time. Describing the splagxnizomai experienced by the Samaritan, Stockwood reminds his fellow Englishmen,

The Lorde worke in vs bowels of compassion ... euery one according to the portion that God hath bestowed vpon vs, maye indéede féele and be touched inwardlye, wyth the miseries of the néedie, and in consideration of the same, gyue muche almes to all the people. ${ }^{78}$

Whether one reads Jesus's parable or Stockwood's exegetical gloss, the Samaritan's actions provide witness of hospitality as visceral care not fiscal remove. Flavius's would-be care for Timon is of this order. That is, Flavius "indéede féele[s]" and is "touched inwardlye, wyth the miseries of the néedie" he witnesses in Timon's unaccommodated estate outside Athens' walls. He would even hazard the full extent of his wealth (a would-be giving of "muche almes") to Timon in his desire to fund the man with what remains of his own dwindling gold, coin that, admittedly, the misanthrope readily rejects.

I concede that there is no direct allusion to the Good Samaritan in Timon, unlike those to the Five Talents. ${ }^{79}$ Yet I would argue that the script it enacts enters Shakespeare's text not directly from the Bible, but rather through the switch points of Timon's dwelling. Likewise, Timon as oikos, as a space of dwelling, whether within Athenian city limits or removed to its outer wilds, presents an example of the person as a site for the practice of hospitality as stewardship in both its failures and potentiality as dwelling. ${ }^{80}$ In Apemantus, for example, Shakespeare demonstrates dwelling's failure as hospitality. By his own account the cynic visits Timon near his cave-turnedhome with the express mission " $[\mathrm{t}] \mathrm{o}$ vex thee" $(4.3 .237)$ even as he offers to "mend" Timon's "feast" (4.3.284) of a freshly uncovered root, an ostensible act of hospitality in the offering of food to the poor. Penning Apemantus' inverse in the character of Flavius, Shakespeare scripts dwelling's potential 
as hospitality. Flavius's is a hospitality premised on agape, an economics (oikos-pneumatics) of care rather than exchange. Like the Samaritan, he expects no return on his investment, desiring instead only genuine and self-sacrificial concern for the other person's well-being. While it is true that Apemantus never actively nor vocally seeks wealth in the form of gold, the cynic's desired coin nonetheless takes the form of Schadenfreude. Flavius, in contrast, seeks no remuneration. Thus it is in the person of Timon, or rather at the site of Timon's person, that Shakespeare offers two divergent modes of hospitality for our reflection: the one of exploitation, the other of dwelling as care.

"What is the state of dwelling in our precarious age?" 81 Heidegger poses this question as he concludes his contemplation of proximal living. In answer he offers the following: we "must ever learn to dwell," which can only be accomplished if we learn to "think for the sake of dwelling." 82 By this he means to think for the sake of relational nearness and the care of and for others. ${ }^{83}$ Timon, I've suggested, offers a space to ruminate upon hospitality as stewardship and its Shakespearean renditions as one such thinking for the sake of dwelling. Not unlike Heidegger's fourfold, my argument has worked in the key of pneumatics. In Spiritual Shakespeares, Ewan Fernie has sought to distinguish (to distance) the spiritual, which precedes revelation, from the religious, which is bound to scripture and covenant. I have not done so; my Timon investigates a spirit that remains invested in the religious. The play's Athens and its exteriors exhibit an understanding of religion as religare, a communal binding together through shared proximity (dwelling) and care (agape) for one another. By Fernie's definition,

spirituality precedes religion and may well take place outside it. Spirituality is an experience of truth, but it is concerned with the truth not of this world but of a world that has not yet and perhaps will never come to be. Spirituality is a mode of opposition to what is. ${ }^{84}$

To the degree that spirituality is a mode of opposition to what is, Shakespeare offers in Timon what I have suggested as a pneumatico-ethical form of hospitality in its dispensation as stewardship. The spiritually entruthed world Fernie envisions that has not yet come and perhaps will never come to be is messianic in its gesture, encoding a desire which, if unfulfilled, harbors the potential for despair on the order of Timon's misanthropy. This spiritual yet nonreligious messianism, however, cuts itself off from the equipment for living developed in positive religion, in the form of prayers, precepts, and parables that help guide our care for one another.

Yet in Timon, Shakespeare offers a glimpse of the messianic in its thinking for the sake of dwelling. Through a false or poetic etymology, Timon's name shares a phonemic association with time. ${ }^{85}$ Indeed, his tragedy may well be that he does not steward well in the time that he is given, a concern archived across the literature on hospitality in the age of Shakespeare. 
Thinking for the sake of dwelling witnesses a similar gesture in Giorgio Agamben's The Time That Remains as the philosopher turns his hermeneutic eye toward the Apostle Paul's delineation of "ho nyn kairos" in his letter to the Romans. ${ }^{86}$ Agamben translates this phrase as "time of the now," signaling not a messianic time of the future, a waiting on the horizon of tomorrow, but a messianic time now, today, in one's present moment-an enactment of the what-could-be-tomorrow today. ${ }^{87}$ This ho nyn kairos is nothing short of the contemporary practice of a hospitality funded by agape. Such call to action in early modern England is espoused in Adams's The Happiness of the Church (1619) whose exhortation supports the Pauline ho nyn kairos in action as agape. According to Adams, the Englishman's fault in hospitality is his dearth of agape, his failure to "walke in loue." 88 Following Adams, ho nyn kairos must be enacted by active (immanent) stewardship today: "The starued soule delights not to heare Charitie, but to feele it." ${ }^{89}$ Like the Good Samaritan one must choose tangible action over empty intent, "bread of the Buttery" over "bread of the Sanctuary." 90

Shakespeare's Athens, like the parable of the Good Samaritan, affords the opportunity to think hospitably in the key of stewardship. Both then and now. It is a space of ho nyn kairos. In its wider registers, hospitality as stewardship is a challenge to reverse Timon's tragic epitaph:

'Here lie I, Timon, who alive

All living men did hate.

Pass by and curse thy fill, but pass

And stay not here thy gait.'

As an ethical practice stewardship is a challenge to dwell rather than pass by. If we take up the call to think for the sake of dwelling, then we must ask ourselves with whom we could and should dwell, rather than continue to pass by unaffected.

\section{Notes}

I am grateful for the participants in the Shakespeare Association of America 2013 seminar on "Shakespeare and Hospitality," where this line of thought was initially brought to my attention.

1. Karl Marx, "The Power of Money in Bourgeois Society," in The Marx-Engels Reader, ed. Robert C. Tucker (New York: Norton, 1978), 103; emphasis in original. All references to Timon follow The Norton Shakespeare: Based on the Oxford Edition, Tragedies, ed. Stephen Greenblatt, Walter Cohen, Jean E. Howard, and Katherine Eisaman Maus (New York: Norton, 2008).

2. Paul Mason, "Timon of Athens: The Power of Money," The Guardian, July 20, 2012, accessed May 23, 2014, http://www.theguardian.com/stage/2012/jul/20/ timon-of-athens-paul-mason. 
3. G. Wilson Knight, "Timon of Athens and its Dramatic Descendants," in Shakespeare and Religion: Essays of Forty Years (New York: Barnes \& Noble, 1967), 220. While it is not my intent to discount Marxist readings of Timon, the aim of this chapter is to move beyond an exclusively economic reading of the play and to direct attention instead to the religious nuances Shakespeare encodes in the practice of hospitality inside and outside Timon's Athens.

4. On Derrida's hauntology, see Specters of Marx: The State of Debt, the Work of Mourning and the New International, trans. Peggy Kamuf (New York: Routledge, 1994), esp. 9, 63, and 202.

5. I borrow my range of dates here from Felicity Heal, "The Idea of Hospitality in Early Modern England,” Past \& Present 102 (1984): 66-93; my argument for the period's turn (or return) to an emphasis on the practice of agape follows Anders Nygren, Eros and Agape. Part I: A Study of the Christian Idea of Love. Part II: The History of Christian Love, trans. Philip S. Watson (Philadelphia: Westminster Press, 1953).

6. Julia Reinhard Lupton, Thinking with Shakespeare: Essays on Politics and Life (Chicago: University of Chicago Press, 2011), 144.

7. Thomas Carter, Shakespeare and Holy Scripture with the Version He Used (London: Hodder and Stroughton, 1905), 444-49. In his recent monograph The Bible in Shakespeare (Oxford: Oxford University Press, 2013), Hannibal Hamlin describes Carter's "scholarly reference work" as "the major precursor to twentieth-century studies" on the subject, 64 .

8. G. Wilson Knight, "The Pilgrimage of Hate: An Essay on Timon of Athens," in The Wheel of Fire: Interpretations of Shakespearean Tragedy (New York: Routledge, 2005), 251; James Bulman, The Heroic Idiom of Shakespearean Tragedy (Cranbury, NJ: Associated University Press, 1985), 126.

9. Lupton, Thinking with Shakespeare, 132. Daniel Boyarin, A Radical Jew: Paul and the Politics of Identity (Berkeley: University of California Press, 1994), 14.

10. Ken Jackson, “'One Wish' or the Possibility of the Impossible: Derrida, the Gift, and God in Timon of Athens," Shakespeare Quarterly 52, no. 1 (2001): 39.

11. The Heideggerian aspect of this definition is derived from Heidegger's essays "Building Dwelling Thinking" and "Letter on Humanism," both collected in Basic Writings, ed. David Farrell Krell (London: Harper Perennial, 2008). For the Hebrew aspect in yashab, see James L. Strong, The New Strong's Exhaustive Concordance of the Bible (Nashville: Thomas Nelson, 1990).

12. For the correlation between pneuma, ruach, and nephesh, see Strong, The New Strong's Exhaustive Concordance of the Bible.

13. On the vocative call in Genesis, see 1:26-28 per mankind's rule/dominion (radah) as benevolent stewardship over the creatures of the earth, and 2:15 per the divine injunction to cultivate (abad) and care (shamar) for Eden/earth. Julia Lupton and Laurie Shannon write of creaturely life in Shakespeare relative to biblical tradition; see Lupton, Thinking with Shakespeare, 131-59, and Shannon, The Accommodated Animal, 29-81. On vocative calling in the Pauline tradition, see Paul's opening addresses in Rom. 1:1-2, 1 Cor. 1:1, 2 Cor. 1:1, and Col. 1:1. Regarding the calling of all believers, see Eph. 4:1-16. Simon Critchley advances the ethico-political importance of vocative calling in his recent monograph, The Faith of the Faithless.

14. Gen. 4:9. 
15. The alterior's aspect of exteriority is taken from Lévinas, see Alterity and Transcendence, trans. Michael B. Smith (Bloomington: Indiana University Press, 1994). Gayatri Chakravorty Spivak parses the alterior in terms of class and subaltern status in her essay "Who Claims Alterity?" in Remaking History, ed. Barbara Kruger and Phil Mariani (Seattle: Bay Press, 1989), 269-92.

16. For a brief yet thorough analysis of this topic, see Heal, "The Idea of Hospitality," Past and Present 102, no. 1 (1984): 66-93. She provides a book-length treatment of early modern English hospitality in Hospitality in Early Modern England (Oxford: Clarendon Press, 1990).

17. Heal, "The Idea of Hospitality," 72.

18. Ibid., 73. On Greek and Roman sources as bases for early modern English treatises on hospitality, see Heal's note 30 .

19. Heal, "The Idea of Hospitality," 80. John Jowett's introduction to The Oxford Shakespeare's Timon of Athens (Oxford: Oxford University Press, 2004) provides a convincing argument for Timon's drafting sometime between 1604 and 1606.

20. Ellis, The Gentle Sinner, 179, quoted in Heal, "The Idea of Hospitality," 70.

21. D. R. Hainsworth, Stewards, Lords, and People: The Estate Steward and His World in Later Stuart England (Cambridge: Cambridge University Press, 1992), 3.

22. Ibid.

23. Ibid., 34.

24. Maurice Hunt, "Qualifying the Good Steward of Shakespeare's Timon of Athens," English Studies 82, no. 6 (2001): 507-20, 513.

25. The Geneva Bible: A Facsimile of the 1560 Edition; emphasis here is mine. On Shakespeare's use of the Geneva Bible, see Shaheen, Biblical References in Shakespeare's Plays; Velz, "Shakespeare and the Geneva Bible"; and Reyken, "Shakespeare and the Geneva Bible." Hannibal Hamlin's recent work, The Bible in Shakespeare, correlates Shakespeare's use of the Geneva Bible but does not suggest it as the playwright's primary or singular Biblical text.

26. Nestle, Greek New Testament.

27. John Bois, Exposition, 202, quoted in Timothy Vande Brake, "The Unjust Steward: Representations on the Early Modern Page and Stage" (PhD diss., University of Alabama, 2000; Dissertation Abstracts International 61, no. 12 [June 2001]: 4790-A), 86.

28. Caron Gentry, Offering Hospitality, 8. For Gentry's extended discussion of hospitality as agape, see 49-62.

29. Thomas Adams, The happiness of the church (London: Printed by G.P., 1619), 131.

30. Ibid., 131-32.

31. Examples of Torahic injunction to help those less fortunate are found most expressively in Leviticus and Deuteronomy; see Lev. 25:25, 25:35, 25:39; Deut. 10:18, 15:7, 15:11.

32. For the full scriptural account of this parable, see Matt. 25:14-30.

33. Matt. 25:1; the talent allotments are as follows: the first servant receives five talents, the second two talents, and the third one talent.

34. Matt. 25:21, 23.

35. Matt. 25:29.

36. Arland J. Hultgren, The Parables of Jesus: A Commentary (Grand Rapids, MI: W.B. Eerdmans, 2000), 274-75.

37. Ibid., 275. 
38. Ibid. For further discussion on this point, see Hultgren, notes 11-12.

39. Ibid.; v. 27 reads, "Thou oughtest therefore to have put my money to the exchangers, and then at my coming I should have received mine own with usury."

40. See Mark 16:15, echoing Ps. 22:27.

41. On the aspect of the Parable of the Five Talents as the giving of one's life qua talents, see Ronald E. Vallet, Stepping Stones of the Steward (Grand Rapids, MI: Eerdmans, 1994), 75.

42. On the burial of money for safekeeping as a common practice in the time of Jesus, see Hultgren, The Parables of Jesus, 275.

43. See act 1 , scene1. These two exchanges follow on the heels of one another; as Ventidius's messenger leaves with Timon's surety of bond, the Old Athenian comes forward with his complaint.

44. Grace Tiffany, “Shakespeare’s Parables," Reformation 16, no. 1 (2001): 145-60, 156.

45. Knights, "Timon of Athens," The Morality of Art, ed. D.W. Jefferson (London: Routledge and Keegan Paul, 1969), 3.

46. On this aspect, see Strong's and Thayer's, s.v. oikonomos. In its Greek transliteration the vocation of steward (oikonomos) bears obvious etymological correlation with the oikos. As a spiritual employment it should be noted that the steward was generally a freedman, that is, a slave released from forced legal servitude. From a Pauline theological position, the steward as oikonomos is one who is freed from the slavery of sin and (as) forced legal servitude; or, one might say that the steward is employed under the auspices of Grace rather than Law; see Romans 7.

47. Ken Jackson, “'One Wish' or the Possibility of the Impossible: Derrida, the Gift, and God in Timon of Athens," Shakespeare Quarterly 52, no. 1 (2001): 34-66, 37.

48. Lévinas, "Judaism and Christianity," 162.

49. Heal, "The Idea of Hospitality," 73.

50. Thomas Adams, The happines of the church, or, A description of those spirituall perogatiues vvherewith Christ hath endowed her considered in some contemplations vpon part of the 12 chapter of the Hebrewes: together with certain other mediations and discourses vpon other portions of Holy Scriptures, the titles wherof immediately precede the booke: being the summe of diuerse sermons preached in S. Gregories London (London: Printed by G.P., 1619), 132.

51. Turner, A nevv booke of spirituall physik, 67.

52. Gervase Markham, A bealth to the gentlemanly profession of seruingmen; or, The seruingmans comforts With other thinges not impertinent to the premisses, as well pleasant as profitable to the courteous reader (London: Printed by W.W., 1598), 13 (B4).

53. Rolf Soellner, Timon of Athens, quoted in John J. Ruszkiewica, Timon of Athens: An Annotated Bibliography (New York: Garland, 1986), 104.

54. Turner, A nevv booke of spirituall physik, 67.

55. Ibid.

56. Ibid., 68.

57. Ibid.

58. Lévinas, "From Ethics to Exegesis," 110.

59. Heidegger, "Building Dwelling Thinking," Martin Heidegger: Basic Writings., ed. David Farrell Krell (San Francisco: Harper Collins, 1993), 348-49.

60. Ibid., 349 . 
61. Ibid.

62. Jowett, The Life of Timon of Athens, 81.

63. A. D. Nuttall, Timon of Athens: Twayne's New Critical Introductions to Shakespeare (Boston: Twayne Publishers, 1989), 88.

64. Hunt, "Qualifying the Good Steward of Shakespeare's Timon of Athens," 513.

65. Heidegger, "Building Dwelling Thinking," 349. Regarding the nonhuman neighbors with whom humans dwell, see 352 .

66. The story of Lazarus being raised from the dead distinguishes the love that "heaven knows" from the love mankind understands. Each report of love spoken by Jesus or about him by his disciples uses a form of agape, whereas the accounts of Jesus' love by all others in the narrative use forms of phileo, friendship love. See John 11.

67. Matt. 25:21.

68. Luke 10:29. The full parable is told from Luke 10:30-37.

69. For an overview of this exegetical model as it was developed by Origen, the Scholastics, and Reformation theologians, see Robert H. Stein, An Introduction to the Parables of Jesus (Philadelphia: Westminster Press, 1981), 45-49.

70. Klyne R. Snodgrass, "From Allegorizing to Allegorizing: A History of the Interpretation of the Parables," in The Challenge of Jesus' Parables, ed. Richard N. Longenecker (Grand Rapids: Wm. B. Eerdmans, 2000), 4.

71. On these points, see Stein, An Introduction to the Parables of Jesus, 49. For Luther's critique of Origen and allegorization more broadly, see Stein, 155, n23.

72. Ibid.

73. Calvin, A Harmony of the Gospels Matthew, Mark and Luke, vol. 3, 38-39, quoted in Stein, An Introduction to the Parables of Jesus, 50.

74. Vallet, Stepping Stones of the Steward, 103-4.

75. Ibid. Concerning the priest's and Levite's risk and subsequent fear of being unclean by association, see Keesmaat, "Strange Neighbors and Risky Care," 278-9; and Stern, A Rabbi Looks at Jesus' Parables, 212-23.

76. Keesmaat, "Strange Neighbors and Risky Care," 281.

77. For the Greek, see Nestle, Greek New Testament; definition is from Strong's, s.v. splagchnizomai.

78. Stockwood, A sermon preached at Paules Crosse on Barthelmew day, 113.

79. Carter suggests Luke 10:34 is glossed in Timon's desire to aid Ventidius at 1.1.9-10. See, Shakespeare and Holy Scripture, 445.

80. In a similar theorization, contemporary German philosopher and cultural scientist Peter Sloterdijk posits personhood through the concept of spheres and the spherical-relational nature of personhood, placing humans in orbit with one another by sharing coincident (e)motions. See, Peter Sloterdijk, Bubbles: Spheres Volume I: Microspherology, trans. Wieland Hoban (Los Angeles, CA: Semiotexte, 2011).

81. Heidegger, "Building Dwelling Thinking," 363.

82. Ibid., emphasis in original.

83. Heidegger's fourfold extends this dwelling as care to both human and nonhuman others, extending the philosophical scope of stewardship to the cultivation of the environment, animals, and objects (things) as well.

84. Ewan Fernie, "Shakespeare, Spirituality and Contemporary Criticism," Spiritual Shakespeares (Abingdon, Oxon: Routledge, 2005), 9.

85. Kermode traces the etymology of Timon's name in Timon of Athens, 238. 


\section{Michael Noschka}

86. Rom. 11:15.

87. Giorgio Agamben, The Time That Remains: A Commentary on the Letter to the Romans, trans. Patricia Dailey (Stanford: Stanford University Press, 2005$), 2$.

88. Adams, The happiness of the church, 132.

89. Ibid.

90. Ibid., 133. 


\section{Contributors}

Thomas P. Anderson is Associate Professor of English at Mississippi State University where he teaches courses on Shakespeare and critical theory. He is the author of Performing Early Modern Trauma from Shakespeare to Milton and co-editor of a book on Foxe's Actes and Monuments. His current book, titled Shakespeare's Fugitive Politics, is under contract with Edinburgh University Press.

David B. Goldstein is Associate Professor of English at York University in Toronto. He is the author of a monograph, Eating and Ethics in Shakespeare's England (Cambridge UP, 2013), which shared the Shakespeare's Globe Book Award. His scholarly work on Shakespeare, modern poetry, and food studies has appeared in numerous journals, including Studies in English Literature, Shakespeare Studies, and Gastronomica, and in several essay collections. He co-edited Culinary Shakespeare (Duquesne UP, 2016) with Amy Tigner, and has written two books of poems, Laws of Rest (BookThug, 2013) and the forthcoming Lost Originals.

David Hillman is a Senior Lecturer in the Faculty of English at the University of Cambridge, and Fellow and Director of Studies at King's College, Cambridge. He is the author of Shakespeare's Entrails: Belief, Scepticism and the Interior of the Body (2007), and of Shakespeare and Freud in The Great Shakespeareans series (2012), and the co-editor (with Ulrika Maude) of The Cambridge Companion to the Body in Literature (2015); (with Adam Phillips) of The Book of Interruptions (2007), and (with Carla Mazzio) of The Body in Parts: Fantasies of Corporeality in Early Modern Europe (1997). He is currently working on a monograph, Greetings and Partings in Shakespeare and Early Modern England.

Andrew Hiscock is Professor of English and Head of the School of English Literature, Bangor University, Wales UK. He is a Fellow of the English Association and a Trustee of the Modern Humanities Research Association. $\mathrm{He}$ is series editor of The Yearbook of English Studies and series co-editor of the Arden Early Modern Drama Guides. He is also Editor (English \& American Literature) of the academic journal MLR. He has published widely on early modern literature and his most recent monograph was 
Reading Memory in Early Modern Literature (Cambridge UP). He is at present preparing a study on Shakespeare's History plays.

Sheiba Kian Kaufman is a doctoral candidate in the English Department at the University of California, Irvine. Her interdisciplinary dissertation, The Hospitable Globe: Persia and the Early Modern English Stage, examines how English representations of Persia and its legendary kings present models of interreligious and intercultural hospitality for early modern and Shakespearean drama. Her project reconstructs a hospitable form of globalization in the early modern period by contending that crosscultural exchange, then and now, is not limited to models of conflict, contest, and domination.

James Kearney is Associate Professor of English at the University of California, Santa Barbara. He is the author of The Incarnate Text: Imagining the Book in Reformation England (University of Pennsylvania Press), and coeditor of a special issue of the journal Criticism addressing "Shakespeare and Phenomenology." He is currently working on a research project that addresses economies of ethical obligation in early modern England. His work has appeared in a variety of journals and collections, including ELR, Shakespeare Studies, Criticism, Spenser Studies, JMEMS, the Oxford Handbook of Shakespeare, and Cultural Reformations.

James Kuzner is Joukowsky Family assistant professor of English at Brown University. He is the author of Open Subjects: English Renaissance Republicans, Modern Selfhoods, and the Virtue of Vulnerability (Edinburgh University Press, 2011) and of Shakespeare as a Way of Life: Skeptical Practice and the Politics of Weakness (Fordham University Press, 2016).

Sean Lawrence is Associate Professor and Associate Head of English at the University of British Columbia, Okanagan. Author of Forgiving the Gift: The Philosophy of Generosity in Shakespeare and Marlowe (Duquesne UP, 2012), Lawrence has also published works in English Studies in Canada, Renascence, and The European Journal of English Studies and several essay collections. Currently his work is organized around ideas of peace in Shakespeare.

Joan Pong Linton is Associate Professor of English at Indiana University. She is the author of The Romance of the New World: Gender and the Literary Formations of English Colonialism (Cambridge University Press, $1998,2007)$, and a number of essays on a range of topics. In addition, she has co-edited two critical anthologies: Go-Figure: Energies, Forms, and Institutions in the Early Modern World (Fordham University Press, 2011) and The Age of Thomas Nashe: Elizabethan London, Print Culture, and Authorship in Early Modern England (Ashgate, 2013). Her current research examines ways in which Shakespeare's plays gesture towards an ethics of theater. 
Julia Reinhard Lupton is Professor of English at the University of California, Irvine, where she has taught since 1989. She is the author or co-author of four books on Shakespeare, including Citizen-Saints: Shakespeare and Political Theology and Thinking with Shakespeare: Essays on Politics and Life. She is a Guggenheim Fellow (2013) and a Trustee of the Shakespeare Association of America (2013-2016). Her current book project is entitled "Shakespeare Dwelling: Habitation, Hospitality, Design."

Thomas J. Moretti is Assistant Professor of English at Iona College and Editor of The Shakespeare Newsletter. His scholarly interests include temporality in early modern English theater and the interplay between religion and gender in early modern English dramas. He has written on religious mediation and gender performance in such works as the Henry VI plays, John Webster's The White Devil, and Philip Massinger and Thomas Dekker's The Virgin Martyr.

Michael Noschka earned his Ph.D. from Arizona State University where he is currently a member of the English faculty. He specializes in early modern literature and critical theory, with broader research interests in ethical philosophy and political theology in both early modern and contemporary culture. Michael has also written about Heidegger, cognitive materialism, and the posthuman in Shakespeare. His current research applies new materialist thinking to readings across the early modern period.

Jessica Rosenberg is an Assistant Professor in the Department of English at the University of Miami. Drawing on the history of the book and the history of science, her research examines the formative connections between poetry, print, and the natural world. She is currently working on a manuscript that explores the relationship between horticulture and textual culture in early modern England. 
This page intentionally left blank 


\section{Index}

Abraham 19, 199

absolutism 7, 68-69, 73-74, 76, 80, 82

Adams, Thomas 29-30, 37n47, 37n51, 37n $52,246,250-251,259,261 \mathrm{n} 29$, $262 \mathrm{n} 50,264 \mathrm{n} 88$

Adelman, Janet 143-144, 154n57-58, $233,240 \mathrm{n} 35$

affordances 1, 3, 5

Agamben, Giorgio 11, 13n11, 85n27, 238, 240n35, 240n38, 241n60, 259, $264 \mathrm{n} 87$

All's Well That Ends Well 34, 191n25

animals 8, 51, 79, 243, 255, 260n13, $263 \mathrm{n} 83$

Anthony and Cleopatra 8, 112-129

Aristotle 22, 35n19, 69, 71, 244;

Aristotelian 22, 24, 60n3, 234, 240n42

As You Like It 3-5, 9, 140, 157-160, 164, 167-168, 169n1, 169n5, 170n10-13, 171n16, 171n24-25, 172n30, 172n32-33, 172n35-37, 172n39, 188, 193n46

Bacon, Francis 22, 24, 36n23, 36n 26 banquet $1-2,6,12 \mathrm{n} 5,23,26,30,33$, 37n51, 171n16, 174, 201; Esther's banquet 201; see also feast; see also dinner

beast 24, 79, 198, 207, 209; see also animal

bed 1, 12n4, 23-24, 40, 60n6, 65n37, $70,121,123,174,176,186,210,231$

Benjamin, Walter 11, 19, 35n12, 233-34, 240n41

Benveniste, Emile 3, 13n10, 113-14, 116, 120, 128n5, 143, 154n55, 199, 218n12

Bergson, Henri 10, 177-178, 190n21

Bible see Scripture; see also Old Testament; see also New Testament Butler, Judith 230-1
Callaghan, Dympna 32, 37n56, 60n6, $228,240 \mathrm{n} 25$

Calvin 116, 138, 152n25, 256;

Calvinists 212

capitalism 3, 40, 62n16, 235, 238

Chaucer 24, 27

childhood see friendship

chivalry $6,29,127$; chivalric romance 224

Christianity see also hospitality; Christ 11, 30, 136-7, 144, 146, 152, 199, 223, 232-3, 236-7, 255-6

Christian bible 243-4; see also New Testament; see also Scripture

Christmastime See holiday

citizen 21, 85n27, 85n31-32, 197, 200, 213; in Coriolanus 67, 72-75, 79; citizenship 199, 209, 213-14

Comedy of Errors 3

communitas 74

conversion 198, 204, 207, 209, 213, $215-16$

Coriolanus 5-7, 21, 67-86, 121, 130n 30,135

creaturely, estate 243,255 ; life 2 , 5,244

Derrida, Jacques 7-8, 19-20, 35n12, 35n12-13, 35n17, 43, 59, 67, 69, 76, 83n7, 84n14, 85n34, 90, 92, 102-4, 108n9, 110n34, 110n38, 110n43-4, 112-16, 120, 122, 128, 129n8, 133, 139-41, 143, 149, 150n5, 153n41-2, 154n44-46, 154n53, 155n67, 158-60, 164, 167-8, 176-8, 199-200, 242-4, $260 \mathrm{n} 4$; on the origin of the word hospitality 134; On Hospitality 10, 13n11, 60n7, 61n9, 68, 83n2, 83n4, 153n29, 190n13; The Politics of Friendship 83n7, 84n13, 190n11; on friendship 86n40, 86n42 
Desdemona 9, 6, 133, 142-50, 198, 207-10, 214; virginity of 155 n 69

Dionysus 23, 36n24, 37n55

dinner 3, 48, 118, 126, 128, 168, 175, 179-81, 183, 197, 210-11; see also banquet; see also feast

dramaturgy 29; dramaturgical choices 1 ; hospitality of/as 9, 133; of reception 4 drink 2, 18, 80, 107, 113, 119, 189n3, 212, 227, 242, 253; drinking 44, 119; see also food

ecology 2, 5, 8; ecological questions 1,3 economy $5,7-8,11,39-40,44-6,52$, 56, 58-9, 61n12, 62n16, 62n18, 66n48, 89, 222, 224, 229; economic transactions 4; economies of debt/ exchange $4,89,102$; of friendship 70 , $74,78,108 \mathrm{n} 21$; of hosting/hospitality $6,42,60 \mathrm{n} 7,93$; of representation 65n42; moral economy 41, 42, 44-46, 51, 53; in The Winter's Tale 89-90, 94-95, 98, 100, 104, 107n3 emergency, state of 19,214 enemy 4, 19-20, 25, 113, 120, 124, $156,192 \mathrm{n} 34,201-2,214,222$; in Coriolanus 67-78 (friend-enemy distinction $73,78,81,83$ ); neighborenemy 256; pregnant enemy 237 , 241n55; public enemy 113 entertain 46-47, 94, 157, 165, 178-9, 184, 201, 222; entertaining i, 168, 218n19, 223; entertainment 3-5, 17, 22, 26, 29, 37n46, 46, 48, 52, 63n21, 89, 107n4, 112, 115, 118, 123, 174, 175-6, 179, 186-7, 192n44, 193n50, 203, 215, 218n19; entertainer 12n2

Erasmus 19, 35n8, 71, 135, 139, 150n11, 150n16, 153n31

ethics 3-4, 10, 92, 114, 223, 244, 248; and drama 211, 223, 237-38; and hospitality $11,25,92-4,108 \mathrm{n} 10$, 114-15, 133, 200, 211, 224, 230, 236-7, 258; obligations and challenges $8-9,17,49,53,65 \mathrm{n} 42$, 84n14, 92, 109n28, 140, 199-200, 202, 230; of stewardship 242-43, 259; see also Levinas

family 6, 22, 34, 192n34, 222-4; familial bond 125, 159, 202, 207, 217; support 230; see also household father 20-1, 34, 39-40, 55-6, 57, 105, 120, 125, 176, 178, 198,
203, 210; church fathers 18, 236, 256;forefather 24; in King Lear 181, 183-4, 186, 187; of Susanna 226; in Troilus and Cressida 20; in Twelfth Night 225, 227; see also husbandry feast $8,23,26,29,31,33,50,52$, $67,75,82,119,121,157,170 \mathrm{n} 13$, 257; feasting 29, 41, 45-5, 48, 63, 118, 120; see also banquet; see also dinner

food 2, 4, 25, 26, 72, 76, 112, 118-19, $129 \mathrm{n} 18,158,162-4,168,171 \mathrm{n} 16$, 175, 187, 189n3, 204, 207, 211-12, 242, 253, 255, 257; see also drink; see also feast

friendship 5, 7-8, 18, 67-83, 83n3, 84n14, 85n34, 86n40, 86n42, 89, 117, 120-1, 125, 134, 148-9, 160, 164, 168, 180, 200, 203, 251-53; childhood friendship 92-3, 98

Freud, Sigmund 40, 44

gift 3, 8-9, 41, 44, 51, 66n48, 89-91, 93, 95, 97, 99, 101-7, 112-120, 122, 127-8, 174, 176, 201, 225; gifting 5, 32, 97, 243-6, 247, 250-1; in Anthony and Cleopatra 113; and Levinas 114; and Mauss 9, 112-113

Goldstein, David B. 211

guest $1,4-7,17,19-21,28-30,32$, 68-9, 72, 76, 91, 99-101, 112-13, 120, 159, 165, 174-6, 178, 188, 197, 199, 204, 209, 251; audience as guest 2, 4, 229, 235; foreign/stranger guests $5,17,33,143,200-2,208$, 213, 224-5, 230; greeting/receiving 3,92 ; rights and protection of $3,25-6$; royal/sacred guest $1,10,17$, 190n9; uninvited/unruly 199, 210

Hamlet 5-7, 39-43, 46, 55-59, 60n1-2, 60n4, 60n6, 60n8, 61n8, 61n39-40, 113, 129n7, 135, 141, 154n47, $154 \mathrm{n} 57,155 \mathrm{n} 76,164,175,242,252$ harbinger $1,12,12 \mathrm{n} 2$

Heal, Felicity 13n10, 63n22-3, 83n2, $107 \mathrm{n} 4,115,129 \mathrm{n} 18,182,189 \mathrm{n} 5$, 192n34, 222, 239n3, 244, 250, 260n 5, 261n16-20, 262n49

Hebrew bible 6, 243-4; see also Old Testament; see also Scripture

Heidegger, Martin 108n10, 140-1, 154n43, 179, 240n27, 243, 254-55, $258,260 \mathrm{n} 11,262 \mathrm{n} 59,263 \mathrm{n} 65$ 
holiday 42-4, 46-48, 50-2, 60 58, 61n8; Christmas/Christmastime 6, 39, 42-55, 58-9, 60n8, 60n12, $62 \mathrm{n} 20,63 \mathrm{n} 22-3,64 \mathrm{n} 30$

Homer 6, 22, 26, 35n22, 36n24, 37n42 hospitality, and chivalry 3, 24, 127 , 224; and culture 21, 33, 199-205, 212-16, 252; inhospitality 10-12, 20, 53, 57, 73, 160, 175-6, 179, 180-5, 187-8, 223-4, 237-8, 242, 244 ; introduction to Shakespeare and 1-12; laws/codes of 25-6, 30-1, 33, 43, 67, 120-22, 137, 208, 224; performance/act of $29,59,90,117$, $128,140,158,201$; and risk 3-4, 8, 83, 89-111, 113, 116, 158, 161, 167, $175,208,224,248,256-7$; and ritual 1-2, 5, 7, 11, 32, 39, 60n $2,62 \mathrm{n} 18$, 73-4, 121-2, 125-6, 134-6, 141, 229, 230, 234; Roman hospitality 72-80; and sleep 1-3, 71, 77-8, 178-9; tables of $1-2,6,17-18,39$, $159,170 \mathrm{n} 9,250-52$; and theater 4, 9, 19, 133, 158, 165-9, 174, 181, 185-9; violated/failed 27, 40, 227; see also economy; see also entertainment; see also ethics; see also friendship; see also Derrida; see also housekeeping; see also husbandry; see also Kant; see also Levinas; see also stranger

hostage $69,72,74,92,176$

hostis 4, 19-20, 113, 199, 209

hostility $10,19,83,97,114,134,157$, 175-6, 185, 198-9, 201-2, 207, 209, 211, 214, 216, 218n19, 228

housekeeping 3, 6-7, 39, 41, 46, 51, 232, 245

Honig, Bonnie 198, 205, 214

Hunt, Maurice 237, 241n55, 245, 255 , $261 \mathrm{n} 24,263 \mathrm{n} 64$

husbandry 4, 6-7, 39, 41-3, 45-6, 48-9, 51-2, 54, 58, 60n2, 61n10, $62 \mathrm{n} 17,63 \mathrm{n} 21,65 \mathrm{n} 37,66 \mathrm{n} 44$;

Julius Caesar 120, 123

Kant, Immanuel 3, 10, 13n10, 200, 218n16

Kottman, Paul 12n5, 32, 38n59, 159, 170n8

King Lear; 2-3, 5, 10, 32, 61n12, 121, 135, 174-179, 186-193, 234; as “zero-sum economy” 61n12
Lacan, Jacques 40, 60n2

Levinas, Emmanuel 7-9, 13n11, 20, 33, 38n60-1, 84n14, 90, 104, 108n8-16, 110n44-7, 112-6, 119-22, 127-30; and ethics $92-5,114,133,147$, 150, 155n74, 156n79, 167, 170n6, $171 \mathrm{n} 16,218 \mathrm{n} 18$

Lupton, Julia Reinhard 20, 73, 104, $157,165,179,197,214,242-3$

Luther, Martin 8, 90, 101-3, 110, 138, $152 \mathrm{n} 25,212,256,263 \mathrm{n} 71$

Macbeth 1-2, 12-13, 29, 32, 35n15, 38n59, 175, 182, 189n6, 192n33

Marlowe, Christopher 24, 36n30, 73, $84 \mathrm{n} 3,123,127,141,198$

marriage 6, 27, 39-41, 45, 121, 169, 173n40, 208, 210, 213-14, 216, 222-5, 231, 237, 249; remarriage 55,57

Mauss, Marcel 8-9, 45, 89, 97, 112-20, 128; See also gift

McNulty, Tracy 10, 224, 228, 231

Measure for Measure 31, 141, 154n48

Merchant of Venice 5, 10, 45, 16n16, 197-8, 203-4, 207-21

Merry Wives of Windsor, The 32, 66n43

messianic 6, 10-11, 42, 233-7, 258-9

Midsummer Night's Dream 135

Montaigne, Michel de 69, 71, 83n7, 170n10, 171n16

mother 7, 39-41, 55, 57, 75, 80, 136, 151; See also father

Nashe, Thomas 30, 37n50, 45-7, 58, 63, 127

neighbor 3, 7, 14n11, 50, 72, 94, 184, 192n34, 197, 240n23, 242-9, 256, 263n75; neighborly $45,63 \mathrm{n} 23$, 243,254

New Testament 18-19, 136, 236, 244;

1 Corinthians 11; 2 Corinthians 13:12 137, 2 John 10-11 137; Mark 237;

Romans 16:16 137; 1 Thessalonians 5:26 137, 2 Thessalonians 3:17 137; Paul's instructions on greeting; see also Paul

Nunn, Trevor 2, 12n5

Odyssey 12; See Homer oikos 5-6; 8, 17, 22-4, 31, 33-6, 243-7, 255-8, 262n46

Old Testament 19; see also Bible; see also Scripture 
Othello 5, 9-11, 32, 133, 142-56, 191n25, 197-8, 206-10, 213-21

pageant 160; pageantry 63n22

Palmer, Daryl W. 13n10, 20, 35n15, 37n46, 63n21, 107n4, 188, 190n9, $211,221 \mathrm{n} 43$

party $2,8,138,120,168,152 \mathrm{n} 25$; see also entertainment

patriarchal 3, 157, 168, 172n36, 222, 225, 229

Paul 11, 137, 214, 223, 232-6, 259;

Pauline 11, 199, 211, 233, 245, 247

Pericles 4, 217n7

personhood 208, 224-5, 231, 235, $263 n 80$

phenomenology 3-5, 12n5, 35n16, 108n12, 178, 182, 190n10, 191n25, 218n19, 243; Bergeson's phenomenology 10, 177

polis 5-6, 22-3, 31, 36n 24

potentiality $85 \mathrm{n} 27,133,198,233,257$ property $11,22,41,45,65 \mathrm{n} 35,66 \mathrm{n} 43$, $96,123,149,152,184,223-5$, 228, 231-2

rape $4,27,225,227,240 \mathrm{n} 34$ reciprocity $3,5,8,58,102,116,243$, 247, 249-53

Reformation 3, 5, 17, 36n27, 63n22, 110n34, 137-9, 143, 152n21, 192n34, $212,217 \mathrm{n} 3,256,262 \mathrm{n} 44,263 \mathrm{n} 69$ rights, of citizenship 199, 214; of guests 3, 200, 208, 222

ritual See hospitality

Romeo and Juliet 108n4, 188, 219n19

Schmitt, Carl 75, 82-3, 86n41, $86 n 43$

Scripture 6, 10, 223, 233-4, 244, 248, 258; Judeo-Christian 11;

2 Corinthians 137; Esther 201, 205 ; Exodus 126; Ezra 201; Genesis 244; Hebrews 244; Jeremiah 226-7; Job 188, 193n48; 2 John 137; Leviticus 200; Luke 137; Matthew 137, 244;

Nehemiah 201; Romans 137, 214, 232, 244, 259; 12 Thessalonians 137; see also Christ; see also Hebrew Bible; see also Old Testament; see also Paul; see also Susanna Seneca 8, 18, 33, 90, 96-8, 100-2, 244
Shakespeare, William, theater 233, 237; sonnets 57; see also individual play titles

Shannon, Laurie 69-71, 83n3, 84n8, 260n 13

sleeping 49, 54, $65 \mathrm{n} 37$

sovereign $7,41,46,48,61 \mathrm{n} 12,68-70$, 73-6, 79-84, 100, 159, 168, 214-16, 230

stranger 3-4, 6, 10-11, 17-18, 25-6, 29, 33, 68, 108n12, 143, 175, 179, 184, 192n34, 197-208, 210-14, 223-4, 228-38, 256

stewardship 10-11, 17, 242-49, 255-61

Stubbes, Phillip 43, 47, 51, 55, 124

Susanna 10-11, 223, 225-27, 229, 233-34, 239n10-13, 239n21, 240n22, 240n40

Taming of the Shrew 31, 240n34

Tempest, The 35n9, 154n57

theology See hospitality

thrift 5-7, 39-51, 55-66

Timon of Athens 5, 10-12, 110n34, 116, 242-4, 246-63

Tottel, Richard 48, 52-4, 57, 59, 71

Travels of the Three English Brothers, The 5, 10, 197-221

Troilus and Cressida 5-6, 17, 19-38, $150,165,166$

Tusser, Thomas 7, 42-53, 58-9, 61n10, 62n20, 63n 21, 64n33, 65n42

Twelfth Night 5, 10-11, 42, 56, 202, 222-3, 225-6, 231, 234-41

universality 93-4, 115, 197, 200

virtue $6,19,40,42,68,81,158,201$, 212, 224-7, 233

wedding See marriage

Winter's Tale, The 5, 8, 89-95, 98-100, 103-11, 163, 225

wife $1,21,26,57,90,94,116,144$, 148-9, 168, 183, 201 224-5, 226, 231-2; as commodity 22; housewife $41,49-50,54$

xenos 17, 20 xenophobia 18, 197, 217n2, 221n49

Zizek, Slavoj 40, 44, 60n3 